\title{
Em busca de novas epistemologias: A TEMÁTICA INDÍGENA sob o olhar da pós-graduação
}

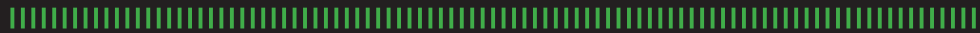

Josélia Gomes Neves | Adir Casaro Nascimento | Darci Secchi José Lucas Pedreira Bueno | Juracy Machado Pacífico (Orgs.)

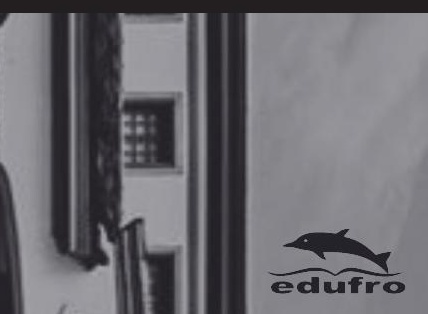




\section{EMBUSCADENOVASEPISTEMOLOGIAS: A TEMÁTICA INDÍGENA SOB O OLHAR DA PÓS-GRADUAÇÃO}

Josélia Gomes Neves

Adir Casaro Nascimento

Darci Secchi

José Lucas Pedreira Bueno

Juracy Machado Pacífico

(Organizador@s)

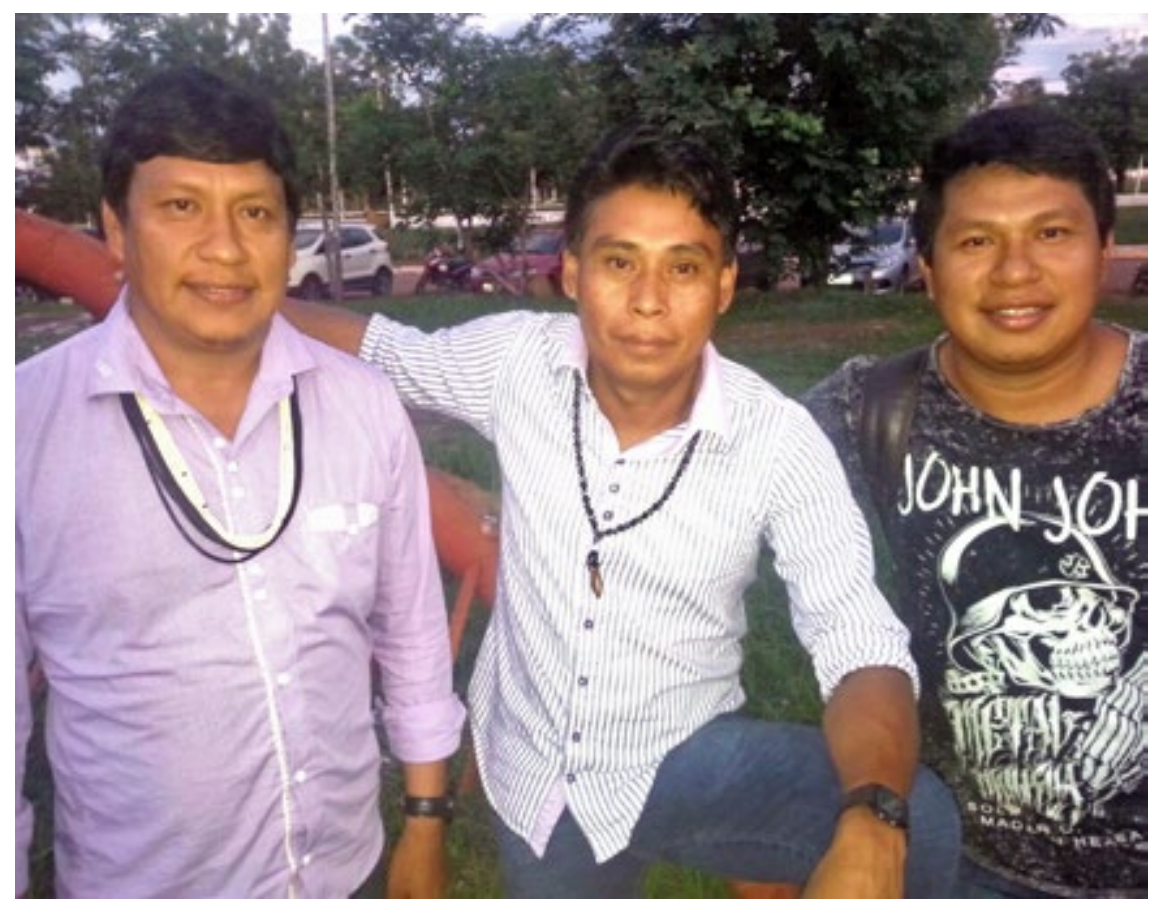

(da esquerda para a direita):

Joaton Pagater Surui, Zacarias Kapiaar Gavião e Luiz Weymilawa Surui 
Reitor Ari Miguel Teixeira Ott

Vice-Reitor José Juliano Cedaro

EDITORA DA UNIVERSIDADE FEDERAL DE RONDÔNIA

$\begin{array}{ll} & \text { CONSELHO EDITORIAL } \\ \text { Presidente } & \text { Lou-Ann Kleppa } \\ & \text { Ariana Boaventura Pereira } \\ \text { Carlos Alexandre Trubiliano } & \text { Eliane Gemaque Gomes Barros } \\ & \text { Gean Carla Silva Sganderla } \\ \text { Leandro Soares Moreira Dill } & \text { Márcio Secco } \\ & \text { Marli Lúcia Tonatto Zibetti } \\ & \text { Pedro Ivo Silveira Andretta } \\ & \text { Ricardo Gilson da Costa Silva } \\ & \text { Xênia de Castro Barbosa }\end{array}$

Editora Filiada
Edufro - Editora da Universidade Federal de Rondônia BR 364, Km 9,5
Campus Unir
76801-059 - Porto Velho - RO
Tel.: (69) 2182-2175
www.edufro.unir.br edufro@unir.br




\section{EMBUSCADENOVASEPISTEMOLOGIAS: A TEMÁTICA INDÍGENA SOB O OLHAR DA PÓS-GRADUAÇÃO}

Josélia Gomes Neves

Adir Casaro Nascimento

Darci Secchi

José Lucas Pedreira Bueno

Juracy Machado Pacífico

(Organizador@s)

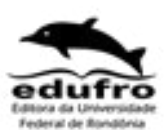

Porto Velho

2021 
(C) 2021 by Josélia Gomes Neves, Adir Casaro Nascimento, Darci Secchi, José Lucas, Pedreira Bueno, Juracy Machado Pacífico, (Organizadores)

Esta obra é publicada sob a Licença Creative Commons Atribuição-Não

Comercial 4.0 Internacional.

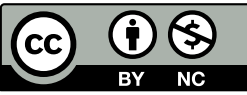

Capa:

Leidijane Rolim

Revisão:

Jeane Mari Spera

Projeto gráfico:

Edufro - Editora da Universidade Federal de Rondônia

\section{Diagramação: \\ Alcindo Donizeti Boffi \\ Impressão e acabamento: \\ Seike \& Monteiro Editora}

Dados Internacionais de Catalogação na Publicação

Fundação Universidade Federal de Rondônia (UNIR)

Ficha Catalográfica elaborada pela Biblioteca Central da UNIR

F981 Fundação Universidade Federal de Rondônia.

Em busca de novas epistemologias: a temática indígena sob o olhar da pós-graduação/ organização Adir Casaro Nascimento, Darci Secchi, José Lucas Pedreira Bueno, Josélia Gomes Neves, Juracy Machado Pacífco. - Porto Velho, RO: EDUFRO, 2021.

286 p.; il.

ISBN: 978-65-87539-42-3 (físico)

ISBN: 978-65-87539-43-0 (digital)

DOI: $10.47209 / 978-65-87539-43-0$

1. Ensino superior. 2. Pós-graduação. 3. Cultura Indígena. 4. Escolas Urbanas. 5. Relações interculturais. I. Nascimento, Adir Casaro. II. Secchi, Darci. III. Bueno, José Lucas Pedreira. IV. Neves, Josélia Gomes. V. Pacífco, Juracy Machado. VI. Fundação Universidade Federal de Rondônia.

CDU 39:378(811.1) 
Aceitar e respeitar a diferença é uma dessas virtudes sem o que a escuta não se pode dar. Se discrimino o menino ou menina pobre, a menina ou o menino negro, o menino índio, a menina rica; se discrimino a mulher, a camponesa, a operária, não posso evidentemente escutá-las e se não as escuto, não posso falar com eles, mas a eles, de cima para baixo. Sobretudo, me proíbo entendê-los. Se me sinto superior ao diferente, não importa quem seja, recuso-me escutá-lo ou escutá-la. [...]. Se a estrutura do meu pensamento é a única certa, irrepreensível, não posso escutar quem pensa e elabora seu discurso de outra maneira que não a minha. Nem tampouco escuto quem fala ou escreve fora dos padrões da gramática dominante. E como estar aberto às formas de ser, de pensar, de valorar, consideradas por nós demasiado estranhas e exóticas de outra cultura? 



\section{Sumário}

13 PREFÁCIO

17

APRESENTAÇÃO

25 1. LINGUAGEM, DECOLONIZAÇÃO E PRODUÇÃO DE IDENTIDADES INTERCULTURAIS: A PRESENÇA INDÍGENA TUPARI, MAKURAP E SURUI NAS ESCOLAS URBANAS DA AMAZÔNIA Josélia Gomes Neves (PPGEE Prof/UNIR) Shelly Braum (PPGEEProf/UNIR)

251 Introdução

262 Colonialismo, colonialidade e as possibilidades de outras formas de conhecimento: as epistemologias do sul

3 O olhar da Antropologia Etnopedagógica para a presença de estudantes indígenas nas escolas urbanas em Rondônia

40 olhar docente para a presença indígena Tupari, Makurap e Surui na escola urbana em Alta Floresta e Cacoal-RO

5 Decolonizando o olhar docente: interpelações das presenças indígenas Tupari, Makurap e Surui em direção a novas epistemologias

6 Considerações finais Referências

2. EXISTE UM LUGAR PARA AS ESCOLAS INDÍGENAS NO CENTRO-OESTE E NA AMAZÔNIA?

Darci Secchi (PPGE/UFMT)

$47 \quad 1$ Para situar o debate

4922 Uma breve retrospectiva histórica

$53 \quad 3$ Relendo os discursos sobre o alcance das escolas indígenas

56

4 O engodo da idealização das escolas indígenas

63 Referências 
65

65

66

71

85

85

88

90

96

97

99

5. O POVO INDÍGENA ARARA-KARO DE RONDÔNIA: CENÁRIOS HISTÓRICOS E A COLONIZAÇÃO NA AMAZÔNIA BRASILEIRA

Maria Isabel Alonso Alves (UFAM /PPGE/UCDB)

Heitor Queiroz de Medeiros (PPGE/UCDB)

99

100

109

111

119

120

3. AS CONTRIBUIÇÕES DOS ESTUDOS CULTURAIS PARA OS ESTUDOS COM CRIANÇAS INDÍGENAS

Adir Casaro Nascimento(PPGE/UCDB)

Rozane Alonso Alves (UFAM)

1 Introdução

2 Estudos culturais e crianças indígenas: possibilidades teórico-metodológicas

3 A pesquisa com crianças indígenas no contexto de Mato Grosso do Sul e Rondônia a partir do campo dos Estudos Culturais Referências

4. INDÍGENAS NA EDUCAÇÃO SUPERIOR EM RONDÔNIA Regina Aparecida Costa (PPGE/UNIR) José Lucas Pedreira Bueno (PPGEEProf/UNIR) Juracy Machado Pacífico (PPGEEProf/UNIR)

1 Introdução

2 A educação superior e o acesso a indígenas

3 Indígenas de Rondônia na educação superior e curso de Licenciatura em Educação Básica Intercultural da unir

4 Considerações finais

Referências

1 Introdução

2 As implicações da colonização na constituição da Amazônia legal Brasileira

3 A contribuição da Comissão Rondon no surgimento do município de Ji-Paraná, Rondônia

4 "Nós Arara": os Karo-Rap de Rondônia

5 Considerações finais

Referências 
123 6. CULTURA INDÍGENA NO COTIDIANO DA ESCOLA YWARÁ PURUBORÁ: CONTRIBUIÇÕES PARA A (RE)CONSTRUÇÃO DA IDENTIDADE

Anatália Daiane de Oliveira Ramos (PPGE/UFMT)

Marli Lúcia Tonatto Zibetti (PPGE/MAPSI/UNIR)

1231 Introdução

1242 Identidade: breve discussão

12730 trabalho com a cultura indígena na escola Ywará Puruborá

1444 Considerações finais

145 Referências

147 7. A CRIANÇA KAIOWÁ E O SEU TERRITÓRIO

Antonio Hillário Aguilera Urquiza (UFGD)

Sônia Rocha Lucas (Saberes/UFGD)

$147 \quad 1$ Introdução

1492 História e relatos de Bonifácio Reginaldo

Duarte acerca do território Pakurity

1573 O território Pakurity

1614 A criança Kaiowá e o território

1675 Considerações finais

168 Referências

$170 \quad$ Entrevista

171 8. RELAÇÕES INTERCULTURAIS E AS EXPECTATIVAS DE ESTUDANTES ESTRANGEIROS EM UMA ESCOLA DE FRONTEIRA

Emanuelly Cristiny Vieira Rodrigues (PPGP/MAPSIIUNIR)

Maria Ivonete Barbosa Tamboril (PPGP/MAPSIIUNIR

$171 \quad 1$ Entre fronteiras...

1752 Dialogando com diferentes conceitos de cultura

$177 \quad 2.1$ Sobre a interculturalidade

1792.2 Inteculturalidade na educação

1813 Entrada e permanência de estudantes imigrantes no sistema educacional deGuajará-Mirim: desafios e possibilidades

1823.10 direito à educação e os imigrantes 
3.2Panorama sobre a educação em

Guajará - Mirim e a inserção de estudantes

imigrantes em uma escola de fronteira

186

4 Considerações finais

189

Notas

190

Referências

193

9. POVOS INDÍGENAS EM RONDÔNIA: O ENSINO SUPERIOR COMO NOVA FERRAMENTA FRENTE À COLONIALIDADE

Thaís Oliva Fernandes Sanders (PPGE/UFMT)

1941 Introdução

1942 Os povos indígenas no desenvolvimento

do Estado de Rondônia

196

3 A Universidade Federal de Rondônia e a presença da diversidade étnica Amazônica

199

4 As expectativas das comunidades indígenas sobre o cursode licenciatura em educação básica intercultural

20150 acadêmico do curso Licenciatura em Educação Básica Intercultural

2047 Considerações Finais

205 Referências

207 10.0 EU E O OUTRO: A TEMÁTICA INDÍGENA NA ESCOLA E A PERCEPÇÃO DE ALUNOS E PROFESSORES

Neide da Silva Campos (COEDUC/PPGE/UFMT)

Suzana Helena Alves de Arruda (SEDUC-MT)

Maria Angela de Arruda Bastos (SEDUC-MT)

Beleni Saléte Grando (COEDUC/PPGE/UFMT)

2071 Introdução

2092 Os professores e a temática indígena:

desvelando os preconceitos

2133 A percepção dos alunos sobre os povos indígenas

2174 Considerações finais

218 Referências 
219 11. ESTUDANTES INDÍGENAS EM ESCOLAS URBANAS: O QUE NARRAM PESQUISADORES E PESQUISADORAS?

Armelinda Borges da Silva (PPGE/UFMT)

2191 Introdução

2202 Determinantes da migração indígena para os centros urbanos

2233 Breve compêndio de trabalhos acadêmicos:

a presença de estudantes indígenas em escolas urbanas

2304 Considerações finais

231 Referências

233 12. INDÍGENAS MUDAM O MODO DE FAZER GUERRA: TROCARAM A BORDUNA PELA CANETA!

Anderson Martins (PPGE/UFMT)

2331 Apresentação

2342 Os Rikbaktsa

2363 A guerra contra os seringueiros

2394 A ação pacificadora dos jesuítas

2435 As técnicas e estratégias de pacificação

2466 A pacificação sob o olhar dos Rikbaktsa

2477 O Pe. João Dornstauder, um Ancestral Rikbaktsa

2488 A intervenção dos Jesuítas era necessária?

2549 Conclusão

256 Referências

257 13. INSTITUIÇÃO ESCOLAR E DIFERENÇAS: ALGUMAS CONSIDERAÇÕES

Patrícia Dias (SEDUC/MT)

2571 Introdução

2582 Breve contextualização sobre diferenças e educação escolar

2623 As tipologias de escola classificada pelo Inep no Censo Escolar

262

3.1 Escola "comum"

265

3.2 Escolas exclusivas para educação especial

267

3.3 Escolas em área de assentamento (educação do campo) 
268

269

272

273

273

274

275

275

276

277

278

281
3.4 Escolas Quilombolas

3.5 Escolas indígenas

a) Escolas para índios nas missões

b) Escolas dos postos indígenas

c) Escola da aldeia

d) Escola indígena itinerante

e) Escolas sem escolas

f) Escola da floresta

g) Aldeia Escola

4 Conclusão

Referências 


\section{Prefácio}

O Brasil, felizmente, produz belas surpresas, mesmo nesta época sombria na qual direitos indígenas e sociais são tão ameaçados. Este livro dedica-se a um assunto pouco ou ainda não estudado: como crianças e adultos indígenas morando fora de suas terras, enveredando pela cidadania brasileira em centros urbanos, vivem o sistema escolar do país, em especial o público, desde o ensino fundamental até a universidade. A grande questão é como os acolhe a sociedade não indígena que, de uma maneira geral, apesar da afirmação dos povos indígenas nas últimas décadas, ainda revela ignorância e preconceito sobre quem são os nossos trezentos povos indígenas, com cerca de duzentas e cinquenta línguas, com sua riqueza de formas de vida, tradições, artes, e com as dificuldades e conflitos de se adaptarem a grandes transformações e a valores inteiramente diversos.

É uma alegria ler os treze capítulos de tantos pesquisadores, provenientes de Mato Grosso, Rondônia, Mato Grosso do Sul, de diferentes universidades. Mestrandos e doutorandos, alguns em trabalhos de conclusão de curso, quase todos com escrita primorosa, revelam o rigor de investigação teórica e de campo, o empenho em afirmar a autonomia e o espaço para o mundo indígena, trazem à baila uma inesperada bibliografia recente. Era difícil imaginar que já houvesse uma reflexão tão aprofundada como a da pesquisa de antropologia e etnopedagogia da Universidade Federal de Rondônia.

O primeiro capítulo aponta para a linha mestra da coletânea, de "decolonizar o conhecimento", e tem a virtude, como os demais, de unir a abstração ao concreto. Abre um caminho novo, ao mostrar como uma docente não indígena, que não tinha nenhum conhecimento sobre quem são os povos indígenas, embora próximos de onde vivia, vai descobrindo o que pensam, suas qualidades, as razões da timidez ou silêncio em sala de aula de seus alunos, cuja língua materna - para ela outra revelação - não era o português, pois aprenderam a falar em muitas outras línguas indígenas. 
Como é louvável a atitude dessa professora, ao se aventurar por um repertório antes não desbravado e se enriquecer com a nova fonte.

A importância das línguas perpassa a maioria dos treze textos que se seguem, como não poderia deixar de ser. É tão elementar perceber que quem não fala uma língua, ou fala mal, não pode entender aulas, professores e colegas... e no entanto essa constatação óbvia é ignorada, não apenas nas escolas, mas em múltiplas situações, no Brasil e no exterior. As línguas indígenas, ao menos rudimentos de algumas, a informação sobre quais são, deveriam constar do universo das escolas brasileiras. Há décadas houve projetos de incluir o tupi no currículo, depois abandonados. E, no entanto, mesmo nas melhores universidades, grandes intelectuais ainda hoje declaram seu espanto - para nosso espanto! - ao ouvir sobre a amplitude do espectro brasileiro linguístico.

Em um curto prefácio não é possível comentar todo o conteúdo de um livro tão denso; mas alguns ensaios podem ser apontados como um emblema dos demais. O sétimo capítulo sobre a criança Kaiowá desperta uma emoção que é simbólica do que se passa no país como um todo, pois a questão Guarani Kaiowá é uma das mais trágicas e vergonhosas para o estado brasileiro. Os autores têm o mérito de estudar o quadro histórico desses povos, acrescido de um belo depoimento do líder Bonifácio Duarte, de Dourados, mais que explícito sobre o esbulho de terras que têm sofrido, e sua teimosia admirável de voltar ao lugar de origem. Analisam com propriedade o processo jurídico e a mobilização para assegurar as terras tradicionais da aldeia de Pakurity, ainda sem solução. Continuam para dar voz às crianças Kaiowá que, sem acesso às terras ancestrais, moram em acampamentos; promovem para elas uma oficina de desenho. Ficou patente que o lar por elas desenhado é a tenda à beira da estrada. Como um país da grandeza do nosso suporta ver em tal estado a infância dos mais antigos habitantes, donos da terra? Parodiando uma frase de James Baldwin sobre a discriminação aos negros nos Estados Unidos, um Estado brasileiro que assim trata os índios não pode ser igualitário e não serve para os cidadãos como um todo. 
O capítulo oitavo, exemplar, sobre estudantes bolivianos em Guajará-Mirim, estende com pesquisa in loco o alcance da temática indígena nas escolas ao tema da imigração, central no mundo e nestas fronteiras brasileiras.

Evoquemos mais um caso, o do sexto capítulo, sobre a escola Ywará Puruborá, um povo "ressurgido", que até há pouco não conseguira ser reconhecido como indígena. Comove sua ânsia de compor um currículo indígena, pois cresceram esparsos, e pouco lhes resta da língua indígena, que tentam reconstruir. Mas nem se falarem apenas o português, e não se lembrarem de tradições antigas, deixam de ser um povo indígena, em luta por sua terra, com justo orgulho, unindo-se aos demais.

Leio com profundo envolvimento os ensaios sobre os povos com quem convivi - Tupari, Makurap, Ikolen, Arara, Suruí Paiter, Zoró, Cinta Larga e outros - cujos formandos universitários e pós-graduandos conheci crianças, com o orgulho de vê-los agora pesquisando, ensinando, atravessando e levando os demais a pontes entre os dois mundos, com uma dignidade a ser imitada.

Gostaria de encontrar todos os autores dos treze capítulos, para dar parabéns e elogiar o que cada um escreveu, e para debatermos as complexas questões interculturais, tão bem aqui delineadas.

Esta leitura aponta para um aprendizado a ser feito sempre pela sociedade brasileira, e cria, pelo exemplo, esperança e otimismo, com força para resistirmos ao preconceito, à ignorância, ao poder econômico e à desigualdade.

Ressurgiremos do caos atual de 2017, à moda dos valentes Puruborá.

Betty Mindlin

São Paulo, 24 de março de 2017. 



\section{Apresentação}

"Em busca de novas epistemologias: a temática indígena sob o olhar da pós-graduação" é uma coletânea organizada por pesquisadores e pesquisadoras de três diferentes universidades brasileiras, e compõe-se de textos que apresentam resultados de pesquisas desenvolvidas em programas de pós-graduação.

O livro surge do anseio de pesquisadores e pesquisadoras de diferentes lugares do país, sendo doutores, mestres, doutorandos e mestrandos de diversos Programas de Programa de Pós-Graduação, que trazem para o centro das discussões e de suas pesquisas questões voltadas para as diferenças de gênero e etnia. Neste livro, destaca-se a temática indígena.

As pesquisas presentes nesta coletânea certamente partem da necessidade sentida de se pensar a educação com o outro, bem como pensar a [...] educação para o reconhecimento do "outro", para o diálogo entre os diferentes grupos sociais e culturais, (CANDAU, 2008, p. 52) ${ }^{1}$. Os textos apresentam discussões que caminham ao encontro das proposições e análises desta autora e, nesta direção reconhecem que tem sido difícil a concretização de uma proposta formativa que produza ruptura com as desigualdades sociais. Entretanto, as demandas por acolhimento das diferenças representam interpelações que tensionam as exclusões e com isso podem engendrar brechas de possibilidades solidárias rumo a um projeto outro de humanização.

As três instituições e seus programas de Pós-Graduação que organizam esta coletânea, com resultados de pesquisas recentes, são: Universidade Federal de Rondônia, com o Programa de Pós-Graduação em Educação Escolar - Mestrado e Doutorado Profissional ((PPGEEProf/UNIR) e o Programa de Pós-Graduação em Psicologia - Mestrado Acadêmico (UNIR); a Universidade Federal de Mato Grupo, com o Programa de

1 CANDAU, Vera Maria. Direitos humanos, educação e interculturalidade: as tensões entre igualdade e diferença. Revista Brasileira de Educação, Rio de Janeiro, v. 13, n. 37, p. 4556, 2008. (p. 52). 
Pós-Graduação em Educação, Mestrado e Doutorado (PPGE/UFMT) e Universidade Católica Dom Bosco (UCDB), com o Programa de Pós-Graduação em Educação. Além das instituições organizadoras, pesquisadores de outras instituições também participam da coletânea com a apresentação de resultados de pesquisas.

A temática da coletânea responde às exigências dos programas scricto sensu em Educação que têm em comum a preocupação em aprofundar estudos acerca das diferenças culturais sobretudo no ambiente escolar, particularmente a questão indígena. Essas preocupações têm se traduzido em linhas e grupos de pesquisa, produção de teses e dissertações, daí a importância da divulgação acerca da produção desse conhecimento.

Em tempos de difíceis diálogos sobre as diferenças, coloca-se como necessário pensar outras possibilidades de enfrentamentos políticos, econômicos, sociais e ambientais. Acreditamos que "Na realidade, o que buscamos foi, de um lado, tratar da realidade tal como ela é, ainda que se mostre pungente; e, de outro lado sugerir a realidade tal como ela pode vir a ser, ainda que para os céticos nosso vaticínio atual apareça risonho)" SANTOS, 2003, p. 13) ${ }^{2}$.

O capítulo 1, Linguagem, decolonização e produção de identidades interculturais: a presença indígena Tupari, Makurap e Suruí nas escolas urbanas da Amazônia, de Josélia Gomes Neves (PPGEEProf/ UNIR) e Shelly Braum (PPGEEProf/UNIR), discute o trabalho pedagógico em perspectiva intercultural a partir da presença de estudantes indígenas Suruí, Tupari e Makurap nas escolas urbanas de Rondônia. As autoras identificam o trabalho como sendo crítico-reflexivo e oriundo da Linha de Pesquisa "Antropologia Etnopedagógica e Currículo" do Grupo de Pesquisa em Educação na Amazônia (GPEA) da Universidade Federal de Rondônia. $\mathrm{O}$ material escrito foi elaborado no segundo semestre de 2016 no município de Ji-Paraná. Para as autoras, trata-se da discussão envolvida pelas Epistemologias do Sul, que são, na verdade, uma forma de destacar os referenciais de conhecimento produzidos no hemisfério Sul,

2 SANTOS, Milton. Por uma outra globalização: do pensamento único à consciência universal. 10. ed. Rio de Janeiro: Record, 2003. 
caracterizadas pelas diferentes manifestações culturais dos diversos povos e linguagens.

O capítulo 2, de autoria de Darci Secchi (PPGE/UFMT), inicia com um título interrogativo: Existe um lugar para as escolas indígenas no centro-oeste e na Amazônia? No texto o autor propõe o debate sobre as escolas indígenas, considerando que nas últimas décadas pode-se verificar significativas mudanças no tratamento da temática educacional indígena. O autor destaca que nessas últimas décadas os próprios índios entraram em cena para discutir políticas de escolarização e para exigir uma educação escolar voltada ao atendimento dos seus interesses, de maneira que a educação escolar passou a ser vista como uma política pública, como um direito de cidadania. $\mathrm{O}$ autor considera que é nesse cenário que os limites e as possibilidades das atuais escolas indígenas precisam ser configurados e, com isso, o texto discute as questões: Existe a possibilidade real de instituir escolas indígenas convergentes com os interesses e necessidades de suas comunidades? E, se sim, teriam elas apenas um lugar, apenas um modelo, um formato e um projeto educativo válido para todas as escolas da região? As questões são instigantes e levam o leitor e leitora e pensar sobre a realidade, culturas e políticas educacionais atuais.

As contribuições dos estudos culturais para os estudos com crianças indígenas é o título do terceiro capítulo desta coletânea. Produzido pelas autoras Adir Casaro Nascimento (PPGE/UCDB) e Rozane Alonso Alves (PPGECH/UFAM), discute sobre como o campo teórico dos Estudos Culturais vem contribuindo nas pesquisas desenvolvidas no âmbito do Estado de Mato Grosso de Sul, bem como no Estado de Rondônia, especificamente nas pesquisas com crianças indígenas. $\mathrm{O}$ estudo discute, desse modo, as limitações, as aproximações, os distanciamentos, os deslizes que produzem os caminhos metodológicos e as percepções desses caminhos, enquanto campo de experiências, a partir dos diálogos com os Estudos Culturais.

No quarto capítulo, intitulado Indígenas na educação superior em Rondônia, Regina Aparecida Costa (PPGE/UNIR), José Lucas Pedreira Bueno (PPGEEProf/UNIR) e Juracy Machado Pacífico (PPGEEProf/ UNIR) apresentam um panorama parcial da presença de indígenas na 
educação superior, em Rondônia, objetivando a análise e a compreensão de políticas direcionadas à educação superior indígena, bem como a formação do professor e da professora indígena. $\mathrm{O}$ estudo observa que a presença de alunos indígenas vinculados ao ensino superior ainda é pequena considerando o percentual relativo a alunos não indígenas. $\mathrm{O}$ estudo apresenta um levantamento realizado por meio de estudo bibliográfico, pesquisa documental e entrevistas, em que se analisou o Projeto Pedagógico do Curso de Licenciatura em Educação Básica Intercultural, ofertado pela Fundação Universidade Federal de Rondônia, Campus de Ji-Paraná.

O povo indígena Arara-Karo de Rondônia: cenários históricos e a colonização na Amazônia brasileira é o quinto capítulo da coletânea. Foi produzido por Maria Isabel Alonso Alves (PPGE/UCDB) e Heitor Queiroz de Medeiros (PPGE/UCDB) e o texto é um desdobramento de pesquisa no âmbito do Programa de Pós-Graduação em Educação, da Universidade Católica Dom Bosco (PPGE/UCDB), que objetiva verificar a produção das identidades/diferenças das mulheres/professoras/indígenas da etnia indígena Arara-Karo, localizada no município de Ji-Paraná, Estado de Rondônia. Este texto apresenta um breve cenário histórico sobre a constituição do povo Arara-Karo e sua relação com o processo de colonização da Amazônia brasileira. São reflexões que buscam se aproximar das questões ligadas à colonização da região amazônica. $\mathrm{O}$ argumento principal do texto refere-se à ideia de que os deslocamentos e ressignificações nos modos de organização, seja no contexto social seja no cultural das populações indígenas, especificamente os Arara-Karo, foram intensificados com o processo de colonização.

Anatália Daiane de Oliveira Ramos (PPGE/UFMT) e Marli Lúcia Tonatto Zibetti (MAPSI/UNIR), no texto Cultura indígena no cotidiano da escola Ywará Puruborá: contribuições para a (re)construção da identidade, sexto capítulo da coletânea, descrevem e analisam as formas como a cultura indígena comparece no cotidiano do trabalho pedagógico da Escola Ywará Puruborá. Os dados foram obtidos por meio de pesquisa do tipo etnográfico, realizada na Aldeia Aperoi - Seringueiras/RO e envolveu a participação de 15 sujeitos. Os instrumentos para produção dos 
dados foram: análise documental, observação participante, diário de campo e entrevistas. Os resultados indicam que a escola tem sido um lugar de revitalização e divulgação da cultura indígena, centrando-se principalmente no ensino da Língua Puruborá. O trabalho com outros elementos da cultura na referida escola acontece em situações específicas, possivelmente em decorrência da histórica expropriação sofrida por este povo, tanto de suas terras, quanto de seus costumes, obrigados a sobreviver entre a população não indígena. Dessa forma, os professores Puruborá que atuam na escola não vivenciaram a educação indígena do seu povo. Para as autoras, embora as professoras acreditem e respeitem as práticas culturais, a forma como conseguem inseri-las na escola é por meio do desenvolvimento de projetos que recolhem e socializam algumas dessas práticas (pintura, mitos e outras) contribuindo para sua revitalização. Conclui-se que, mesmo que essas práticas tenham se tornado objetos de ensino, ainda assim estão contribuindo para a (re)construção da identidade do povo Puruborá.

A criança Kaiowá e o seu território, sétimo capítulo, de Antonio Hilário Aguilera Urquiza (Pós-Graduação em Antropologia/UFGD) e Sônia Rocha Lucas (PPGAnt/UFGD), apresenta resultados de pesquisa em andamento no programa de Pós-Graduação em Antropologia da UFGD. Trazem para discussão as percepções da criança indígena da aldeia Pakurity - Dourados/MS, acerca do seu território tradicional, assim como acerca da sua realidade de acampamento em que está inserida. No estudo o autor e a autora levaram em consideração as representações e vínculos dessas crianças com o território vivenciado em conjunto com a construção de sua identidade, principalmente em relação ao atual processo de regulamentação fundiária do território tradicional, ou seja, do seu Tekoha. Os Guarani e Kaiowá sofreram historicamente a expropriação de seus territórios, muitas vezes praticada pelo próprio governo federal. $\mathrm{Na}$ atualidade, vivem em pequenas parcelas de seu território tradicional e com o comprometimento de sua reprodução física e cultural, direitos garantidos nos ordenamentos jurídicos nacionais e internacionais.

Relações interculturais e as expectativas de estudantes estrangeiros em uma escola de fronteira é o oitavo capítulo da coletânea. Nele, 
Emanuelly Cristiny Vieira Rodrigues (MAPSI/UNIR) e Maria Ivonete Barbosa Tamboril (MAPSI/UNIR) apresentam resultados de pesquisa que teve como objetivo principal analisar as relações interculturais no processo de escolarização de estudantes bolivianos em uma escola pública em uma região de fronteira no município de Guajará-Mirim em Rondônia. Os resultados foram obtidos por meio da investigação de elementos que fundamentam essas relações, tais como a imigração, a inclusão dentro da escola e o desenvolvimento das relações.

\section{Povos indígenas em Rondônia: o ensino superior como nova fer-} ramenta frente à colonialidade é o nono capítulo da coletânea e, nele, Thaís Oliva Fernandes Sanders (PPGE/UFMT) aponta que o processo histórico do desenvolvimento do estado de Rondônia significou para os povos indígenas alteração do modo vida, desterritorialização e consequente reorganização comunitária, de modo que esses fatores, na atualidade, são a razão da criação de Organizações Indígenas e pautas de lutas. A autora destaca, como exemplo, a educação institucionalizada, que exigiu mobilização das organizações indígenas do estado para a criação do curso de formação superior de professores indígenas, por representar novas possibilidades comunitárias. O trabalho analisa o Curso de Licenciatura em Educação Básica Intercultural, desenvolvido na Fundação Universidade Federal de Rondônia, Campus de Ji-Paraná, como um processo histórico, buscando descrever a importância da formação docente indígena para as comunidades.

Neide da Silva Campos (COEDUC/UFMT), Suzana Helena Alves de Arruda (SEDUC-MT), Maria Angela de Arruda Bastos (SEDUC-MT) e Beleni Saléte Grando (COEDUC/PPGE/UFMT), no texto $\mathbf{O}$ eu e o outro: a temática indígena na escola e a percepção de alunos e professores discutem os diversos olhares de docentes e discentes sobre a identidade do índio na atualidade. Desse modo, para as autoras, "[...] tematizar sobre as questões indígenas na escola, numa sociedade preconceituosa, é buscar minimizar tais práticas, sensibilizar o outro para as diferentes culturas em relação, numa postura de quem, a partir da educação escolar, busca construir uma sociedade mais humana em relação ao outro.” O texto deste 
capítulo dez apresenta dados e discussões que resultaram da pesquisa exploratória realizada na cidade de Poconé-MT, no ano de 2013. Trata-se de um projeto de pesquisa-ação do Grupo de Pesquisa Corpo, Educação e Cultura (COEDUC/UFMT), que buscou vincular-se à prática pedagógica na formação continuada de professores, cujo recorte temático foi a história e a cultura dos povos indígenas. O projeto foi desenvolvido em parceria com o Centro de Formação e Atualização dos Profissionais da Educação Básica (CEFAPRO/Cuiabá) para os professores da rede estadual de ensino.

No capítulo onze, intitulado Estudantes indígenas em escolas urbanas: o que narram pesquisadores e pesquisadoras?, Armelinda Borges da Silva (PPGE/UFMT) expõe os motivos que contribuem para a migração indígena para centros urbanos, entre eles a diminuição de territórios indígenas e consequentemente a redução dos bens naturais disponíveis para a sobrevivência, a busca de melhoria de vida, a procura de emprego e a educação escolar para os filhos. O estudo foi desenvolvido utilizando-se da pesquisa bibliográfica e apresenta pesquisas desenvolvidas por pesquisadoras e pesquisadores, divulgadas por meio de dissertações, teses e trabalhos acadêmicos relacionados ao indígena em contextos escolares urbanos. A autora delimita sua pesquisa em trabalhos desenvolvidos nos estados da região Norte e Centro-Oeste. Os estudos mostram que os pesquisadores e pesquisadoras constataram a dificuldade das escolas em trabalhar com a presença indígena. É frequente a prática de um currículo eurocêntrico como referência, que deixa em segundo plano as culturas consideradas minoritárias, desvalorizando as manifestações culturais dos povos indígenas que passam a fazer parte da escola. A carência de recursos didáticos específicos e políticas de formação continuada para trabalhar a interculturalidade contribuem para homogeneizar estudantes indígenas e não indígenas.

O capítulo doze, de autoria de Anderson Martins (PPGE/UFMT), denominado Indígenas mudam o modo de fazer guerra: trocaram a borduna pela caneta!, apresenta um breve relato sobre a história dos Rikbaktsa, visando compreender como se deu o seu processo de escolarização e de que modo essa experiência é percebida pelos membros daquela comunidade. $\mathrm{O}$ autor destaca que a implantação de escolas em suas aldeias 
não constitui um evento isolado, mas é resultado de um fenômeno mais amplo, caracterizado como um processo colonizatório. Afinal, será que a troca da "borduna" pela "caneta" deixou esse povo mais fortalecido na luta contra seus inimigos? Essa é uma das indagações que tem inspirado o autor na busca das informações que serão apresentadas no capítulo.

No capítulo treze desta coletânea, de autoria de Patrícia Dias (PPGE/UFMT), denominado Instituição escolar e diferenças: algumas considerações, a autora apreenta a temática escola e diferença, que são desdobramentos de pesquisas realizadas junto ao Programa de Pós-Graduação em Educação da Universidade Federal de Mato Grosso (PPGE/UFMT), no âmbito do Grupo de Estudos e Pesquisa em Educação Escolar Indígena (GEPEEI). A proposta do texto é produzir uma reflexão a respeito das diferenças e educação escolar.

Assim, a coletânea se organiza em capítulos que podem ser lidos de forma independente, embora alguns tratem do mesmo problema. Nesse caso, o leitor ou leitora poderá optar por ler mais que um capítulo que tangenciam a mesma problemática, mas apresentada sob diferentes olhares e referenciais teórico-metodológicos.

Toda a coletânea é um convite para a construção de conhecimentos produzidos a partir de discussões e pesquisas sobre as políticas públicas educacionais e diferenças de gênero e etnia no âmbito da temática indígena na pós-graduação. Um mecanismo de atualização dos trabalhos da saudosa antropologa Aracy Lopes da Silva.

Nesta direção, a fotografia dos mestrandos Joaton Pagater Surui, Zacarias Kapiaar Gavião e Luiz Weymilawa Surui representam a marca simbólica e ritualística do ingresso indígena na pós-graduação da Unir em 2016 na área de educação escolar em um edital próprio.

Com as questões instigantes, necessárias e atuais, desejamos excelentes leituras a todos e todas que se adentrarem nos terrenos das diferenças!

Josélia Gomes Neves Juracy Machado Pacífico 


\title{
1. LINGUAGEM, DECOLONIZAÇÃO E PRODUÇÃO DE IDENTIDADES INTER- CULTURAIS: A PRESENÇA INDÍGENA TUPARI, MAKURAP E SURUI NAS ESCOLAS URBANAS DA AMAZÔNIA
}

\author{
Josélia Gomes Neves (PPGEE Prof/UNIR) \\ Shelly Braum (PPGEEProf/UNIR)
}

\section{Introdução}

Por várias razões, os Povos Indígenas têm se deslocado ultimamente e, com mais frequência, de suas aldeias para as cidades. Nesse processo, dependendo do tempo de duração nas áreas urbanas, as famílias, compreendendo a importância da educação escolar na sociedade atual, matriculam seus filhos e filhas nas escolas não indígenas. Embora em contexto amazônico, localização tradicional da maioria dos indígenas brasileiros na contemporaneidade, esse encontro ainda provoca um conjunto de reações caracterizadas pelo estranhamento.

Nessa direção é que propomos a reflexão em tela, que tem como objetivo principal discutir o trabalho pedagógico em perspectiva intercultural a partir da presença de estudantes indígenas Suruí, Tupari e Makurap nas escolas urbanas de Rondônia. Trata-se de um texto crítico-reflexivo oriundo da Linha de Pesquisa "Antropologia Etnopedagógica: Currículo e Interculturalidade" do Grupo de Pesquisa em Educação na Amazônia (GPEA) da Universidade Federal de Rondônia, elaborado no segundo semestre de 2016, no município de Ji-Paraná.

Os procedimentos metodológicos de caráter qualitativo consideraram a pesquisa bibliográfica (ZEICHNER, 2008; TAVARES, 2011; SANTOS, 2009; QUIJANO, 2009; MINDLIN, 1985; BANDEIRA; BATISTA, 2002; HALL, 1998; NEVES, 2013; SANTOS; SECCHI, 
2013), documentos oficiais (BRASIL, 2008; 2010; 2015) e posterior análise documental (GIL, 2002): um relato de prática pedagógica escrito pela Professora Shelly Braum (2016), documento com o qual dialogaremos no decorrer deste trabalho.

Foi a resposta a uma provocação que fiz a ela, com vistas à escrita deste texto. Ao saber de suas experiências em sala de aula com estudantes indígenas das etnias Tupari, Makurap e Suruí, propus que registrasse de forma reflexiva essa caminhada, que será analisada à luz dos referenciais teóricos e conceituais dos Estudos Culturais: colonialismo, colonialidade e Epistemologias do Sul.

Mas, inicialmente, há necessidade de contextualizar esses povos de culturas e línguas tão diferentes. Quem são os indígenas do Brasil? De acordo com o Censo Demográfico de 2010, eles são 896.917 pessoas distribuídas em 305 etnias, moradores de 505 Terras Indígenas e falantes de 274 línguas. (BRASIL, 2010).

No estado de Rondônia há um quantitativo populacional correspondente a 1.562 .409 pessoas, destas, 12.015 se autodeclaram indígenas. O Censo informa que 9.109 indígenas estão localizados em Terras Indígenas e 2.906 nas cidades. Em Alta Floresta há 436 indígenas de várias etnias, além do Makurap e Tupari na Terra Indígena Rio Branco; em Cacoal, há 1.316 indígenas pertencentes à etnia Suruí Paiter na Terra Indígena Sete de Setembro (BRASIL, 2010).

\section{Colonialismo, colonialidade e as possibilidades de outras formas de conhecimento:3as epistemologias do sul}

Como mencionamos anteriormente, a presença indígena na cidade não constitui uma situação nova. Avaliamos que ela foi intensificada com a criação do estado de Rondônia, possibilitada pela estimulação dos processos migratórios por parte do Governo Federal, a partir do final dos anos 1970, com o intuito de atenuar os conflitos das regiões sul e sudeste do país. Esse evento desencadeou de forma mais contundente tensões e conflitos envolvendo os povos que aqui chegavam com aqueles que aqui já se encontravam. 
O contingente populacional que chegou ao novo estado da federação em 1982, por ausência de políticas públicas efetivas de proteção as sociedades nativas, acabou provocando uma série de desentendimentos complexos, resultando em prejuízos evidentes para as comunidades tradicionais - extrativistas, ribeirinhos e quilombolas. Entretanto, para os povos indígenas, grande parte das etnias em fase de estabelecimento de contato com "brancos", os danos foram irreversíveis, traduzidos em genocídio, redução populacional, perdas linguísticas, rapto de crianças e mulheres, dentre outros, potencializados principalmente em função da ocupação territorial, confirmando que: “[...] a imigração brasileira para Rondônia foi grande e seus efeitos se fizeram sentir sobre a população indígena, com lutas e mortes [...]" (MINDLIN, 1985, p. 17).

Nessa direção Adrian Cowell e Vicente Rios (1990) registraram de perto esses conflitos no tocante documentário " $\mathrm{Na}$ trilha dos Uru Eu Wau Wau", em que explicitam os embates travados entre seringueiros e indígenas provocados pela ação do Estado brasileiro. A problemática foi desencadeada porque o Instituto Nacional de Reforma Agrária (INCRA) assentou uma família de seringueiros em um local de perambulação tradicional de um povo indígena que sequer havia sido contatado, os Uru Eu Wau Wau.

O confronto ocasionou inicialmente a morte de duas pessoas da família do seringueiro Chico Prestes, que foram flechados pelos Uru Eu Wau Wau, e o rapto do menino Fábio. Durante certo tempo, a família tinha a esperança de encontrá-lo, entretanto, após o contato realizado pela Fundação Nacional do Indio (FUNAI) com os indígenas dessa etnia, souberam que infelizmente a criança também havia morrido. $\mathrm{O}$ acompanhamento por parte do documentarista ao longo de vinte anos permitiu compreender que havia ocorrido, no início dos anos 1980, situação semelhante sofrida pelos índios: um seringueiro havia raptado uma menina e duas mulheres Uru Eu Wau Wau.

Outros casos semelhantes a esse são localizados (LEONEL JR., 1995), (LÉVI-STRAUSS, 1996) e (MINDLIN, 1985), talvez em outros suportes, outras linguagens, como as fontes orais, já que os registros da História Regional pouco falam das populações tradicionais ou dos povos 
indígenas, sobretudo nesse período. A implantação de Programas de PósGraduação na Universidade Federal de Rondônia, principalmente nos cursos de mestrado, tem possibilitado uma promissora produção acadêmica nessa direção.

De igual modo e em perspectiva inovadora, a criação do Curso de Licenciatura em Educação Básica Intercultural na UNIR - Campus de Ji-Paraná, responsável pela formação docente indígena desde 2009, ocasião em que aconteceu o primeiro vestibular diferenciado, também representa uma aposta na construção de saberes locais na visão indígena. Os Trabalhos de Conclusão de Curso (TCC), por exemplo, têm priorizado temas e metodologias que, aos poucos, vão preenchendo as lacunas deixadas pela historiografia regional na produção de conhecimento amazônico.

É importante compreender, por meio dos antecedentes históricos, que a complexa convivência entre indígenas e não indígenas tem sido marcada por relações de poder capitalista com evidentes perdas para os nativos, tanto no processo colonizatório ocorrido no início do século XX como no que foi visibilizado de forma mais intensa no começo dos anos 1980. Parece haver uma incompreensão generalizada da diversidade que marca essas culturas na Amazônia. Adotamos o entendimento que:

[...] A cultura de um povo é nada mais nada menos que o conjunto das respostas que aquele povo dá às experiências pelas quais ele passa e aos desafios que ele sofre. A língua, bem como a cultura, vão sendo moldadas ao longo do tempo. Qualquer grupo social humano é um universo completo de conhecimento integrado, com fortes ligações com o meio em que se desenvolveu. O conhecimento das línguas indígenas e, através delas, o conhecimento da experiência e do conhecimento acumulados pelos povos que as falam é de valor cultural e social inestimáveis. (TEIXEIRA, 1995, p. 293).

Os Estudos Culturais têm problematizado essas incompreensões e relações apontando que o processo colonizatório tem duas fases: a inicial, conhecida como a subalternização dos povos, denominada de colonialismo, fenômeno desencadeado pelos projetos expansionistas da Europa, em 1500, 
por exemplo, em direção ao chamado Novo Mundo. Esse colonialismo político é caracterizado pela "[...] dominação que envolve a negação da independência dos povos subjugados, [...], exclusão e das relações profundamente desiguais entre grupos sociais”. (TAVARES, 2011, p. 3).

No entanto, a independência dos países subjugados, não representa por si só, nessa perspectiva teórica, o fim da dominação. Os Estudos Culturais advogam que o colonialismo do poder segue reeditado, na atualidade, sob o manto da colonialidade que, no dizer de Quijano, é “[...] a parte invisível e constitutiva da modernidade [...] é um dos elementos constitutivos e específicos do padrão mundial do poder capitalista” (2009, p. 73).

A colonialidade, nesse sentido, representa uma extensão do colonialismo. Significa afirmar que as perversões do antigo modelo colonial se presentificam na atualidade por meio de mecanismos no âmbito político, econômico e, sobretudo, epistemológico, principal arma da atual forma de colonização, na qual o conhecimento representa uma: “[...] imposição e resultado das consciências colonizadas, das relações intersubjetivas de dominação [...], desvaloriza os outros seres não humanos, os humanos não ocidentais e todos os que não são brancos [...]” (TAVARES, 2011, p. 5).

Daí a necessidade de "descolonizar o conhecimento" (QUIJANO, 2007). Representa um esforço de elaborar o pensamento a partir de outras lógicas, levando em conta elementos outros que não o da racionalidade, por exemplo, considerado um clássico modelo excludente. Enfim, examinar profundamente o que avaliamos importante numa visão fundamentada na participação e na solidariedade entre os povos e, a partir daí, construir epistemologias específicas adequadas a este contexto: Epistemologias do Sul (SANTOS, 2010).

As Epistemologias do Sul constituem uma forma de destacar os referenciais de conhecimento produzidos no hemisfério Sul, caracterizadas pelas diferentes manifestações culturais dos diversos povos e linguagens que, ao longo dos processos de dominação - colonialismo e colonialidade -, sofreram toda sorte de perversões, aniquilamentos, exclusões e silenciamentos.

É na perspectiva das Epistemologias do Sul que escrevemos este texto. Uma oportunidade de narrar uma temática invisibilizada pela lite- 
ratura acadêmica: a presença indígena em escolas urbanas. Para além da vitimização, denunciar as lacunas existentes, afirmar a identidade amazônica, problematizar nosso "eu" colonizador, experimentar a interculturalidade por meio da vivência com os povos indígenas na cidade, percebendo-os como sujeitos históricos.

\section{$3 \mathrm{O}$ olhar da Antropologia Etnopedagógica para a presença de estudan- tes indígenas nas escolas urbanas em Rondônia}

As repercussões acerca da presença de estudantes indígenas em escolas urbanas na Amazônia, [...] é tensionada por uma série de conflitos - velados ou explícitos [...]. De um lado o olhar da escola sugere dificuldades de responder pedagogicamente de forma adequada a este contexto, por outro, as famílias indígenas afirmam situações de desconforto vivenciadas pelos estudantes. [...] há necessidade do Poder Público avançar em duas medidas básicas: assegurar formação continuada docente por meio da implantação concreta da Lei 11.645 de 2008 e materializar políticas públicas diferenciadas para indígenas em contexto urbano. (NEVES, 2013b, p. 7-8).

A preocupação acadêmica de compreender e documentar a presença indígena em contexto urbano e suas repercussões na escola de Rondônia iniciou em 2010. Nesse período, empiricamente, chegaram até nós as vozes indígenas, vindas tanto do município de Porto Velho como de Ji-Paraná, sobre as difíceis relações estabelecidas na escola da cidade.

As vozes das famílias indígenas diziam do isolamento sentido pelas crianças, da barreira linguística referente à pressão para a imediata fala convencional em português, quando vinham de uma situação de uso quase que exclusivo da língua materna na aldeia; que não se sentiam à vontade em falar sua primeira língua na escola em função dos comentários depreciativos dos colegas, apelidos, enfim, um conjunto de ocorrências que culminavam no desejo de abandonar a escola.

É possível verificar que o olhar da escola para as diferenças culturais, para os povos indígenas, evidencia desconhecimentos e compreensões 
superficiais ancoradas em imagens cristalizadas. Santos e Secchi (2013) desenvolveram um estudo evidenciando os mecanismos de afirmação e omissão identitária no âmbito do contexto escolar. Ao indagarem, junto à direção escolar de sete escolas urbanas do município de Ji-Paraná, se havia indígenas matriculados nesses estabelecimentos de ensino, obtiveram respostas ambíguas a respeito da atual identidade étnica: “[...]. 'Talvez tenha índios, sim, mas não são índios puros'; 'Eu acho que são mestiços'; 'As mulheres brancas engravidam dos índios e aí já não são puros, né' [...]”. (SANTOS; SECCHI, 2013, p. 59). Assim como os agentes escolares direção e coordenação pedagógica traduzem e classificam os indígenas -, as famílias indígenas também têm o que dizer sobre os ambientes escolares urbanos. Nesse sentido, por meio do desenvolvimento de projetos de iniciação científica e extensão na Terra Indígena Igarapé Lourdes, através do Grupo de Pesquisa de Educação na Amazônia (GPEA) da Universidade Federal de Rondônia, era possível dialogar com as famílias indígenas dos Povos Arara e Gavião e, assim, conhecer suas perspectivas.

Esses elementos foram importantes para possibilitar a elaboração do Projeto Lápis, caderno, flecha e preconceito: feiçôes da violência institucional com crianças indígenas em escolas públicas urbanas de Rondônia, submetido ao Programa Institucional de Bolsas e Trabalho Voluntário de Iniciação Científica (PIBIC) que, a partir daí, desencadeou um volume expressivo de estudos e publicações (ALVES; NEVES, 2012; DIAS; NEVES, 2013; DIAS, 2013; NEVES, 2013B; NEVES; DIAS; NASCIMENTO, 2013; PACÍFICO; TAMBORIL, 2013; DIAS, 2014; DIAS; NEVES; SILVA, 2014; SANTOS, 2014; NEVES, 2016).

O objetivo principal foi investigar o processo de violência institucional que acontece em instituições escolares urbanas de Rondônia, pela perspectiva das crianças indígenas e seus familiares. Nesse período implantamos a Linha de Pesquisa Antropologia Etnopedagógica e Currículo, no intuito de possibilitar um conjunto de estudos e publicações com foco nas possíveis transformações ocorridas no interior da escola, resultantes da interpelação indígena, por meio das matrículas de estudantes nativos nas escolas da cidade ou por meio da implementação da Lei 11.645 de 2008, 
que tornou obrigatório o ensino da História e culturas indígenas no Currículo. Nossa aposta desde então é que o Currículo, nessa perspectiva, pode avançar para a dimensão da interculturalidade (NEVES, 2013A).

\section{$4 \mathrm{O}$ olhar docente para a presença indígena Tupari, Makurap e Surui na escola urbana em Alta Floresta e Cacoal-RO}

Quando entrei em sala e vi que indígenas - Tupari e Makurap - fariam parte das minhas aulas, um filme de terror passou em minha mente: a visão quase geral do grupo que eu pertencia antes de virar professora, os lavradores, é que os índios só tinham direitos e nenhum dever, que eram preguiçosos, que "mamavam nas tetas do governo", que encareciam o custo de vida do brasileiro trabalhador. [...]. (BRAUM, 2016, p. 1).

A formação docente inicial ou continuada em perspectiva intercultural ainda não é satisfatoriamente contemplada nas matrizes curriculares dos Cursos de Licenciatura no Brasil. As diretrizes curriculares para formação de professores e professoras passaram a exigir a inserção das diferenças culturais nos últimos vinte anos. Assim, muitas vezes, ao nos depararmos com culturas tão diferentes, o que vem à mente são as aprendizagens do senso comum. A memória evocada é da colonização de Rondônia, onde as representações sobre os Povos Indígenas estão relacionadas a estereótipos da preguiça, das benesses governamentais, dentre outros. Nesse sentido, o exercício de narração autobiográfica, “[...] é um texto 'vivo de um sujeito historicamente datado e socialmente situado; um texto que revela modos de pensamento e reflete formas de organizar, criar e recriar cotidianamente o mundo. [...] um exercício de autotransformação [...]”. (PÉREZ, 2003, p. 3).

O fragmento anterior evidencia estranhamento, seguido do binômio preconceito e discriminação, uma forma de colonização do pensamento, um comportamento observado com frequência no que se refere às culturas indígenas. O Dicionário On Line de Língua Portuguesa define o termo Preconceito como: [...]. Prejulgamento; [...] opinião ou pensamento acerca de algo ou de alguém cujo teor é construído a partir de análises sem funda- 
mentos, $[\ldots]^{1}$. O mesmo Dicionário informa que a palavra Discriminação significa "[...] ação de segregar alguém, tratando essa pessoa de maneira diferente e parcial, por motivos de diferenças sexuais, raciais, religiosas; ato de tratar de forma injusta [...]"2. Temos o entendimento de que, nas situações de violação étnica, inicialmente, há um pensamento (preconceito) e posteriormente decorre a sua materialização (discriminação), um evidente quadro de violência institucional escolar.

Assim, muitas vezes na sala de aula, considerando a ausência de um processo formativo qualitativo que oriente o fazer pedagógico numa visão intercultural, há o predomínio de pensamentos pré-concebidos, não aprofundados, que, por sua vez, podem acabar orientando a ação ou inação docente. Tavares reconhece que existem mecanismos de controle, onde "[...] exercido pela cultura e pelo poder hegemónicos sobre as nossas mentes imprimindo nelas uma lógica de dominação que passa a reproduzir, em todas as áreas da vida, as relações de poder hegemónico, configurando, também, as subjetividades [...]”. (2011, p. 2).

E a Professora Shelly tinha outras preocupações: "[...] Perguntava- me o que eu faria com alunos que não queriam nada com nada, que só queriam saber de usar celular da moda [...]". A articulação indígena e tecnologia, para significativa parte da sociedade brasileira, ainda é algo emblemático porque altera visivelmente a representação que se tem dos Povos Indígenas: o estereótipo marcado pela imagem de uma pessoa de franja, cocar, tanga e habitante da floresta.

Para Stuart Hall, a identificação é algo que está em constante mudança. Constitui-se e é constituída permanentemente porque tem relação direta com as representações ou interpelações feitas sobre os sujeitos nos diversos sistemas culturais, ou seja, "[...] à medida em que os sistemas de significação e representação cultural se multiplicam, somos confrontados por uma multiplicidade desconcertante e cambiante de identidades possíveis,

\footnotetext{
${ }^{1}$ Disponível em: http://www.dicio.com.br/preconceito/ Acesso: 15/07/2016.

2 Disponível em: http://www.dicio.com.br/discriminacao/ Acesso: 15/7/2016.
} 
com cada uma das quais poderíamos nos identificar - ao menos temporariamente" (2006, p. 5).

Desse modo, é compreensível que os Povos Indígenas, na atualidade, façam usos de recursos tecnológicos. Que construam suas identidades nesse movimento social e histórico marcado por descontinuidades, rompimentos e fraturas. Como outros povos, os Tupari e Makurap viveram diferentes processos históricos: tempo da maloca (antes do contato), tempo dos seringais (CPI/AC, 1996), tempo da migração urbana, situações que sugerem diferentes interpelações que, por sua vez, provocam alterações em seus processos identitários, produzindo trajetórias não lineares, plurais.

A leitura de Hall permite o entendimento de que os indígenas de hoje certamente não são os indígenas do tempo de Cabral, representados nas imagens que a escola nos ensinou. De igual forma, os não indígenas também não são mais como antigamente. Aconteceram profundas alterações culturais e estas produzem repercussões e mudanças na vida de todos os diferentes grupos sociais.

O relato da Professora Shelly, honesto e mobilizador, evidencia que inicialmente pouco conhecimento ela tinha sobre os Povos Indígenas Tupari e Makurap, habitantes da Terra Indígena Rio Branco, localizada no município de Alta Floresta. Meu contato mais próximo com eles veio por meio também da atividade docente. Foi no ano de 2004, ocasião em que ministrei a disciplina de Alfabetização Intercultural para docentes indígenas no âmbito do Projeto Açaí - Curso de Formação Inicial de nível médio para professores e professoras indígenas do estado de Rondônia.

Posteriormente nos encontramos nos Fóruns do Núcleo de Educação Escolar Indígena de Rondônia (NEIRO), entidade composta de lideranças indígenas e representantes indigenistas que atuam em prol da educação diferenciada. Também estive com eles em uma formação continuada de 15 (quinze) dias na Aldeia Colorado, na Terra Indígena Rio Branco. Nesses espaços conheci Isaias Tupari, Raul Tupari, Alessandra Makurap e outros indígenas. Docentes e lideranças de muito valor para seus povos. Amizades que cultivamos até hoje. Encontramo-nos depois na graduação da UNIR, 
na sala de aula cujo esforço comum era de aprofundar a compreensão crítica sobre a escola indígena.

Esses momentos foram extremamente formativos. Pude me aproximar melhor da história de vida dos Tupari e dos Makurap. Ali aprendi que os Tupari falam uma língua do tronco Tupi, pertencente à família linguística Tupari mesma família dos Makurap. Um dos estudiosos deste povo, Franz Caspar (1957) informa que antigamente viviam organizados em aldeias de malocas nucleares, por volta de trinta, distribuídas nas proximidades do Rio Branco.

O processo colonizatório desencadeado no final do século XIX e início do século XX, sob a feição da prática extrativista, constituiu um dos fatores de extrema desagregação do modo de vida dos Tupari e Makurap, conforme atesta Fonseca (2011, p. 27): “Nos seringais, trabalhavam na agricultura, cultivando grandes plantações de arroz, milho, feijão, macaxeira, cana e coleta de castanha. Pelo trabalho compulsório, recebiam roupas e ferramentas de trabalho".

Os relatos que ouvi em sala de aula apontaram que foi principalmente nessa época, por força da atividade seringalista, que ocorreram os processos massivos de desaldeamento e maus tratos, em que núcleos familiares eram separados considerando a lógica organizativa dos proprietários dos seringais. Informação confirmada na pesquisa de Fonseca: "As mulheres eram obrigadas a manter relações sexuais com os seringueiros, sob ameaça; além de trabalhos forçados, os índios eram submetidos a maus tratos, castigados com chibatadas e humilhados. [...]" (2011, p. 28).

Possivelmente essas Epistemologias do Sul não são de conhecimento da maioria dos docentes, até porque o que se tem acesso é a conhecimento monocultural, próprio do projeto colonial. Decorre dessa evidência a necessidade de desocultar essas narrativas, compreender as razões da "timidez" dos indígenas Tupari e Makurap na cidade e, quem sabe, oportunizar um ambiente em que possam falar, um mecanismo que permitirá ensaios rumo a um diálogo de saberes. Uma forma de, talvez, "despensarmos as pedagogias coloniais”, como nos ensina Manuel Tavares (2011). 


\section{Descolonizando o olhar docente: interpelações das presenças indíge- nas Tupari, Makurap e Surui em direção a novas epistemologias}

[...] a migração de índios às cidades é influenciada, em grande monta, pelo modelo de desenvolvimento econômico adotado na região e pela limitação de bens e serviços públicos disponíveis nas aldeias. A falta de oferta do ensino médio nas escolas indígenas; a precariedade de serviços públicos de saúde; a instabilidade alimentar e a escassez de meios de troca, especialmente de dinheiro, são indicados como os principais fatores. As viagens para a cidade para fazer pequenas compras, vender artesanato, receber aposentadoria, fazer exames clínicos ou laboratoriais, etc., demandam tempo, recursos e disposição. [...]. (SANTOS; SECCHI, 2013, p. 57).

De acordo com o seu relato, a Professora Shelly, inicialmente, avaliava os estudantes indígenas como muito tímidos. Compreendia que havia uma grande barreira a ser transposta, no entanto, não se tratava de um objetivo importante. Estava mais preocupada em quem mostrava interesse. Com o passar do tempo, aos poucos, foi percebendo que mesmo tímidos e, como ela mesma afirma, apesar de seu "desdém" frente as suas necessidades, eles tinham uma polidez no comportamento, uma obediência incomparável.

Considerando a reclamação recorrente da indisciplina em sala de aula na atualidade, o fato de ter em sala "alunos obedientes" não era algo que considerasse ruim. $\mathrm{O}$ destaque para as palavras "alunos obedientes" é proposital, pois para ela, no fundo, possivelmente era assim mesmo que os via, como seres sem luz, bem do jeito que jesuítas propagaram por séculos. Essa obediência mobilizou uma curiosidade em conhecê-los melhor. A disponibilidade foi recompensada. A professora foi surpreendida. Como docente da área de linguagem, constatou que os estudantes indígenas Tupari e Makurap sabiam mais línguas que ela, uma vez que, além do domínio de suas línguas maternas, tinham no português a sua segunda língua e, além disso, eram aprendizes escolares de inglês e agora espanhol. Mas que importância tinha uma língua indígena?! 
Mesmo eu querendo dizer isso a mim mesma, sabia que qualquer língua possui uma estrutura e que não há uma língua melhor ou pior, há uma língua mais ou menos valorizada. Este fato começou a mudar como eu concebia os indígenas enquanto educandos. E notei que eles tinham uma facilidade maior que os brancos a aprender a língua. $\mathrm{Co}^{-}$ piavam e resolviam o que estava no quadro com muita atenção e quase nenhum erro, e nenhuma reclamação. (BRAUM, 2016, p. 3).

Assim, o olhar inicial docente via nos estudantes Tupari e Makurap, em função de suas identidades indígenas, possíveis preguiçosos ou eternos dependentes das ações governamentais. Caracterizava um pensamento estereotipado, próprio da discriminação de cunho étnico, aquela endereçada exclusivamente aos índios. Mas essa relação vai mudando. Os discentes indígenas passam por um importante reconhecimento: de observadores ou consumidores para o lugar de sujeitos produtores de conhecimento. Isso foi possível na medida em que houve a abertura por parte da professora para novas racionalidades, talvez propiciada pelo que temos chamado de interculturalidade vivenciada. Nesse sentido, é possível compreender que: "Essa violência que institui o que o outro diferente 'não é' [...], que nega [...], é exercida por aqueles que têm algum tipo de poder na sociedade. Mas isso não significa que essa forma de se relacionar com o outro e os valores produzidos sejam inalteráveis." (BANDEIRA; BATISTA, 2002, p. 131).

A mudança na relação entre a Professora Shelly e os estudantes indígenas Tupari e Makurap confirma que é possível, no âmbito das relações entre diferentes, alterar comportamentos a favor da interculturalidade. No entanto, a timidez dos índios ainda era um problema. Imagino como foram suas infâncias, quantas vezes ouviram dos mais velhos as narrativas dos conflitos responsáveis por tantas mortes, perdas significativas para a memória coletiva do grupo, o quanto os "brancos", esses "outros" tão poderosos tinham sido ruins com os seus parentes. Ao se depararem em sala de aula na escola urbana, há uma reedição do contato com esse "outro" perigoso, um encontro num território alheio. Como não ficar tímido quando se tem históricos de silenciamento? 
A presença de famílias indígenas no contexto urbano configura-se como uma negociação dinâmica e complexa, com uma relação custo-benefício bastante peculiar. Ainda que fustigadas pelo racismo, preconceito, exclusão, violência física e simbólica, etc., a cidade lhes proporciona alguns 'benefícios' que lhes parece justificar o preço pago... Sobrevivendo às condições de vulnerabilidade que o meio urbano reserva aos 'outros', essas famílias experimentam os sabores e dissabores da 'sociedade moderna'. (SANTOS; SECCHI, 2013, p. 57).

Alguns colegas da turma faziam questão de destacar suas identidades indígenas, como se essa identidade fosse um problema, o que provocava ainda mais silêncio. Foi então que a Professora Shelly teve a ideia de evidenciar seus aprendizados linguísticos, explicando à turma que os alunos indígenas estavam à frente de todos no que se refere à aprendizagem de segunda língua. Ocasião em que, na perspectiva da Lei 11.645 de 2008, possibilitou um trabalho pedagógico intercultural com foco no estudo da História e Culturas Indígenas:

Eu perguntava como se dizia uma ou outra palavra na língua materna deles e, a princípio, mesmo desconfiados e tímidos faziam, pois como já disse eram obedientes. Com o passar do tempo, eles falavam mais confiantes e felizes. Sentia até uma ponta de orgulho quando falavam não mais apenas das palavras, mas de costumes que agora também era objeto de minha curiosidade. (BRAUM, 2016, p. 2).

De acordo com o Parecer 14/2015 sobre as Diretrizes Operacionais para a implementação da história e das culturas dos Povos Indígenas na Educação Básica: "A correta inclusão da temática da história e da cultura dos povos indígenas na Educação Básica tem, assim, importantes repercussões pedagógicas [...] para o efetivo reconhecimento da diversidade cultural e étnica da sociedade brasileira [...]”. (BRASIL, 2015, p. 2). Desse modo, a visibilidade em torno das línguas indígenas possibilitou uma produção discursiva pública. Uma oportunidade de afirmação étnica dos representantes de dois importantes povos para o estado de 
Rondônia: Tupari e Makurap. A possibilidade de aprendizagens de outras perspectivas, outras sintaxes, mecanismos certamente que favorecem o enriquecimento do mundo, a aposta em uma:

[...] educação para o reconhecimento do 'outro', para o diálogo entre os diferentes grupos sociais e culturais. Uma educação para a negociação cultural, que enfrenta os conflitos provocados pela assimetria de poder entre os diferentes grupos socioculturais nas nossas sociedades e é capaz de favorecer a construção de um projeto comum, pelo qual as diferenças sejam dialeticamente integradas. (CANDAU, 2008, p. 52).

Entretanto, para a professora ainda havia um "problema": a vagarosidade dos indígenas. Somente quando entendeu que existem diferentes temporalidades, que estão intimamente ligadas às culturas, aos modos de vida construídos no decorrer dos tempos pelos diversos povos, é que reavaliou que não era lerdeza ou preguiça e sim uma maneira de ver, interpretar o mundo.

É importante compreender que foi no Brasil Colônia que surgiu a pecha de que os índios são preguiçosos por não adotarem o modo capitalista de trabalho assentado na ideia da acumulação. Essas reproduções da atualidade são ecos de um passado que, embora distante, permanecem, atestando que: "Ao longo de vários séculos de colonização e entrechoques étnicos, foram construídos estereótipos e discursos que se firmaram em tal proporção nas sociedades americanas, que se tornaram difíceis de serem desmentidos. [...]" (KAUSS; SOUZA, 2011, p. 87).

Problematizar nossas interpretações diante de outras culturas é importante para combater possíveis ações etnocêntricas - orientadas pelo sentimento de qualificar nosso jeito de viver como o melhor, o mais acertado e, em contrapartida, menosprezar os outros modos, principalmente quando não os entendemos e nem queremos entendê-los. Essas relações desiguais e desproporcionais provocam danos às vezes irreparáveis nas consciências subalternizadas, alterando identidades com vistas a sobreviver diante de tanta hostilidade: 
Quem possui uma identidade ferida, ou seja, quem se autodesvaloriza porque é mulher, negro, homossexual, [...], indígena, etc. precisa metamorfosear-se em leão, para ter a liberdade de negar o dever-ser, os valores que the foram atribuídos historicamente, abrindo assim espaço à construção de novos valores. (BANDEIRA; BATISTA, 2002, p.139).

Com a compreensão de que a temporalidade é cultural, ela parou de se preocupar com o tempo da aula de uma hora semanal, o modelo possibilitado pelo "engessado" currículo reservado para a aula de espanhol. Passou a entender que tudo o que era compartilhado significava aprendizado. De igual modo, aos poucos foi entendendo que não há aprendizados melhores ou piores, só os mais ou menos valorizados, resultados das relações intersubjetivas de dominação.

Mesmo sem ter tido uma formação inicial com pressupostos interculturais (WALSH, 2009), é possível observar que os caminhos encontrados pela professora Shelly evidenciam que de fato a experiência é formadora: "É experiência aquilo que nos passa, ou que nos toca [...] e ao passar nos forma e nos transforma. Esse é o saber da experiência: [...] como alguém vai respondendo ao que vai lhe acontecendo ao largo da vida e no modo como vamos dando sentido ao [...] que nos acontece. (LARROSA, 2001, p. 1). Ao tematizar a sua prática pedagógica, encontrou sentido para o trabalho escolar:

Quando fui para o IFRO, vi que havia alunos indígenas. Notei que alguns dos meus colegas se encontravam no mesmo embate pessoal que outrora estive: não temos formação para ensinar indígenas. E somente os próprios índios podem nos ensinar como fazer isso. Muitas vezes vi meus companheiros querendo medir em centímetros o que talvez devesse ser pesado em gramas. Mas ninguém nos ensinou isso. Resultado: alunos indígenas reprovados. Não estou defendendo que os indígenas são melhores ou que devem ser aprovados sem cumprir o que todos os alunos são cobrados. Pelo contrário: acredito que para que eles vençam neste mundo capitalista devem se 'armar' tanto quanto os ditos brancos. Mas esse ensino deve fazer sentido pra eles. E com essa visão fui pra sala de aula: já comecei a valorizá-los e sempre recebi um sorriso em troca. (BRAUM, 2016, p. 2). 
Paulo Freire (1988), no livro Pedagogia da Autonomia, destaca a importância de pensar a prática pedagógica traduzida no trinômio ação/ reflexão/ação. Posteriormente, um movimento significativo será desencadeado: a concepção da professora ou professor reflexivo. Zeichner (2008) interpreta essa reflexão como uma forma de reagir contra os modelos de formação que viam os docentes como meros executores de políticas traçadas em gabinetes. Entende que a prática reflexiva tem a ver com o reconhecimento de que os professores e professoras, juntamente com outros atores, possuem um papel importante no que diz respeito ao seu trabalho.

É essa perspectiva de reflexão na ação que favorece o diagnóstico da prática pedagógica da Professora Shelly. Compreende que a barreira linguística ainda representa um desafio para os estudantes indígenas, pois como ela mesma afirma “ [...] uma das três estudantes do Povo Suruí Paiter fala bem pouco o português. Mas fico encantada quando os vejo apresentar um trabalho em espanhol". Sua aposta é de que, como ela, as meninas indígenas irão vencer a vergonha e o preconceito.

Os Suruí, assim como os Tupari e os Makurap, são povos que sobreviveram a contextos colonizatórios muito hostis. O processo constante da disputa territorial foi intenso, conforme atesta Martins: "Posto Indígena Rio Roosevelt-RO, o sertanista Apoena Meireles está dedicado a difícil tarefa de convencer 200 índios Suruí de que - embora cercados por dois mil posseiros vindos do sul, [...] eles devem esperar por alguma coisa que mal podem compreender: a FUNAI, o INCRA, a Polícia Federal e sua justiça." (1978, p. 189). Talvez essas lembranças provoquem comportamentos de obediência silenciada. Solidária com as dores da diferença, Shelly sabe que essa situação de vergonha e preconceito atinge apenas alguns grupos sociais no Brasil: "Difícil para mim imaginar esse cenário, pois só hoje em dia consigo perceber que nunca tive que passar por nada disso quando da idade deles”. (BRAUM, 2016, p. 2).

Reconhece que há muito a aprender para poder ensinar mais e melhor e isso vale para os dois lados: “[...] Encontrei colegas que partilham dessa visão e estão um pouco mais a frente que eu nesta jornada. Isso só vai contribuir para que eles sejam valorizados em sua cultura, seus conhecimentos, 
suas vivências. [...]”. Uma compreensão a favor da interculturalidade e da descolonização, compreendida como a superação da visão "[...] da vida humana que não dependa da imposição de um ideal de sociedade àqueles que são diferentes, como aconteceu com a modernidade/colonialidade" (MIGNOLO, 2010, p. 32).

Produzir escritas de suas experiências representa um exercício favorável à reflexão. Nesse sentido, possibilita a elaboração de balanços da trajetória pessoal e profissional, na medida em que aponta pontos de chegada e novos pontos de partida. É como se estivéssemos à frente de um espelho. A imagem que se tem é de uma migrante que se instalou na região amazônica, lócus tradicional de diferentes povos: Aikanã, Arara, Arikapu, Canoé, Cinta Larga, Gavião, Jaboti, Karipuna, Karitiana, Makurap, Oro At, Oro Eo, Oro Mom, Oro Nao, Oro WaJe, Oro Waram, Oro Waram Xijen, Oro Win, Puroborá, Sabanê, Suruí, Tupari, dentre outros, além dos não contatados. Povos ainda tão desconhecidos por nós que atualmente compartilhamos o mesmo território. Essa constatação do muito que ainda precisa ser conhecido mobilizou uma escrita autoral, autoavaliativa e propositora de novas caminhadas:

[...] Escrever essas palavras causa em mim uma vergonha absurda, mas também um orgulho absurdamente maior. Vergonha do sistema educativo brasileiro porque nos faltaram muitas aulas de História e Sociologia honestas e verdadeiras desde a época dos meus pais (não se espante quando souber que eles estudaram à época da ditadura) e quiçá dos meus avós, tataravós, etc. Vergonha por não saber reconhecer todas as boas contribuições que a cultura indígena trouxe para a cultura dita branca: e não quero me resumir a tomar banho todos os dias, mas também a contribuição na alimentação, na cultura, na visão de mundo. Mas sinto um grande orgulho que, com o tempo e com a ajuda desses alunos e de colegas, pude transpor o muro do preconceito que me cercava. Transpor não, derrubar. Sinto que, graças a essas experiências, hoje sou uma pessoa e uma profissional melhor.

Portanto, o sentimento paradoxal da vergonha ao lado do orgulho explicita um movimento de olhar para trás e avaliar que, se por um lado, 
teve pouco conhecimento escolar sobre a importância e as contribuições dos diferentes povos indígenas na formação da sociedade brasileira, por outro lado, como é movimento, permite olhar o presente e o futuro como temporalidade promissora.

Isso é possível porque o convívio com os estudantes indígenas e outros colegas docentes podem significar mecanismos pedagógicos na direção de aprendizagens interculturais significativas, confirmando que: "As pessoas vão contando suas experiências, crenças e expectativas e, ao mesmo tempo, vão anunciando novas possibilidades, intenções e projetos. [...] torna-se até difícil separar o vivido do que está por viver. [...] (CUNHA, 1997, p. 1). Significa que as perspectivas, experiências e narrativas estão entrelaçadas, se constituindo como anunciadoras de novos tempos e novas epistemologias, preferencialmente do Sul.

\section{Considerações finais}

O trabalho em tela analisou um relato pedagógico referente à atividade docente com estudantes indígenas em escolas urbanas de Rondônia, à luz das contribuições do Estudos Culturais. Foi possível observar que, por diferentes motivos, dentre eles a ausência de políticas públicas educacionais nas aldeias, os indígenas têm vindo estudar nas cidades. $\mathrm{Na}$ perspectiva docente, a inexistência de formação intercultural ocasiona situações de preconceitos e discriminações étnicas, próprias de um referencial colonizador caracterizado pela produção da violência.

No entanto, o exercício da reflexão crítica docente, desencadeado pela interculturalidade vivenciada, tem permitido avanços no desenvolvimento dessas relações. Ao problematizar as práticas colonialistas a partir das histórias silenciadas dos povos indígenas de Rondônia, é possível compreender que os resíduos ficaram, traduzidos no termo colonialidade, expressas na excessiva timidez e obediência observadas no comportamento dos estudantes. A visibilização das culturas em sala de aula, tal como propõe a Lei 11.645 de 2008, pode representar importantes possibilidades de aprendizagens interculturais na Amazônia. 


\section{Referências}

ACRE. História Indígena. Comissão Pró-Índio do Acre. CPI/AC. Disponível em: http://lemad.fflch.usp.br/sites/lemad.fflch.usp.br/files/lemad-dh usp_hist\%C3\%B3ria_ind\%C3\%ADgena.pdf

ALVES, Rozane Alonso; NEVES, Josélia Gomes. Feições da violência institucional em crianças indígenas nas escolas públicas urbanas do estado de Rondônia na perspectiva de seus familiares. 2012. Disponível em: www.pibic.unir.br/anais/ANAIS\%20PIBIC. Acesso: 20 out. 2014.

BANDEIRA, Lourdes; BATISTA, Analía Soria. Preconceito e discriminação como expressões de violência. 2002. Disponível em: http://www.scielo.br/pdf/ref/v10n1/11632.pdf Acesso: 15 jul. 2016.

BRASIL . Lei 11.645/2008. Disponível em: http://www.planalto.gov.br/ccivil_03/_ ato2007-2010/2008/lei/111645.htm Acesso em: jan. 2014.

Parecer CNE/CEB No 14/2015. Disponível em: http://portal.mec.gov.br/index. php? Acesso em: 22 abr. 2016.

IBGE. Brasil Indígena. Censo 2010. http://indigenas.ibge.gov.br/estudos-especiais-3/o-brasil-indigena. Acesso: 15 jul. 2016.

BRAUM, Shelly. Relato da prática pedagógica: escrita inicial sobre a convivência com estudantes indígenas pertencentes ao Povos Tupari, Makurap e Suruí. Cacoal, Rondônia. 2016. Mimeo. (texto digitado).

CASPAR, Franz. Tuparí (Entre os índios, nas florestas brasileiras). Tradução de M.N. de Souza Queiroz. São Paulo: Melhoramentos, 1953.

CANDAU, Vera Maria. Direitos humanos, educação e interculturalidade: as tensões entre igualdade e diferença. Revista Brasileira de Educação, v.13, n.37, jan./abr. 2008.

COWELL, Adrian; RIOS, Vicente. Na Trilha dos Uru Eu Wau Wau. O destino dos Uru Eu Wao Wau. Documentário, 52’00”. Produção Verbo filmes/cit. 1990.

DIAS, Patrícia; NEVES, Josélia Gomes. Vozes infantis: uma visão da violência institucional na perspectiva das crianças indígenas urbanas de Ji-Paraná. 2013. Disponível em: http:// www.pibic.unir.br/submenu_arquivos/827_anais_do_pibic_2013 Acesso: 12 out.2014.

DIAS, Patrícia. Índios urbanos: razões da migração e repercussões das etnias Arara, Gavião e Zoró nas escolas públicas da cidade de Ji-Paraná-ro. 2013. Monografia (Graduação em Pedagogia) Universidade Federal de Rondônia, Campus de Ji-Paraná,RO, Setembro de 2013.

DIAS, Patrícia; NEVES, Josélia Gomes; SILVA, Armelinda Borges da. Relações interétnicas: indígenas, cidade e escola urbana. Rev. Educa, Porto Velho (RO), v.1, n.2, p. 1-16, 2014. Disponível em: http://www.periodicos.unir.br/index.php Acesso em: 15 jul. 2016. 
DICIONÁRIO ON LINE PORTUGUÊS. Disponível em: http://www.dicio.com.br/preconceito Acesso: 15 jul. 2016.

FONSECA, Mary Gonçalves. Casa de escrever no papeo: a Escola Tuparí da Terra Indígena Rio Branco, Rondônia. 2011. 104 f. Dissertação (Mestrado em Desenvolvimento Regional e Meio Ambiente). Fundação Universidade Federal de Rondônia. Porto Velho. 2011.

FREIRE, Paulo. Pedagogia da Autonomia: saberes necessários à prática educativa. Rio de Janeiro: Paz e Terra, 1997.

FREIRE, Paulo. Pedagogia do Oprimido. 18. ed. Rio de janeiro: Paz e Terra, 1988.

GIL, Antônio Carlos. Como Elaborar Projetos de Pesquisa. 4. ed. São Paulo: Atlas, 2002.

HALL, Stuart. A identidade cultural na pós-modernidade. Rio de Janeiro: DP\&A, 1998.

LÉVI-STRAUSS, C. Tristes trópicos. São Paulo: Companhia das Letras, 1996.

LEONEL JR., Mauro. Etnodicéia Uruéu-au-au: o endocolonialismo e os Índios no Centro de Rondônia, o Direito à Diferença e a Preservação Ambiental. São Paulo: IAMÁ, FAPESP, 1995.

KAUSS, Vera Lucia Teixeira; SOUZA , Marcos Teixeira de. Nus de estoicismo: para além de uma visão eurocêntrica sobre os indígenas. Espaço Ameríndio, Porto Alegre, v. 5, n. 3, p. 85-97, jul./dez. 2011.

MINDLIN, B. Nós Paiter: os Suruí de Rondônia. Petrópolis: Vozes, 1985.

MIGNOLO, W. Desobediência Epistémica: Retórica de la Modernidad, lógica de la colonialidad y gramática de la descolonialidad. Buenos Aires: Ediciones del Signo, 2010.

NEVES, Josélia Gomes. Currículo Intercultural: o processo de aplicação da Lei 11.645/2008 nas escolas públicas da Amazônia. Revista Partes, São Paulo, maio de 2013A. Disponível em: http://www.partes.com.br/educacao Acesso em: 15. 07.2013

NEVES, Josélia Gomes. Povos Indígenas em escolas urbanas da Amazônia: a reedição do contato? Revista Partes: SP.2013B.Disponível em: http://www.partes.com.br/2013/05/15/ curriculo-intercultural/. Acesso em: nov.2013.

NEVES, Josélia Gomes. Memórias Indígenas da Escola urbana. Anais de Evento. Trabalho Completo. SEMIEDU 2016.

NEVES, Josélia Gomes; DIAS, Patrícia; NASCIMENTO, Priscila Araújo do. Povos Indígenas, Escolas Urbanas e Violência Institucional: o que dizem as crianças e o que afirmam as professoras? Anais de Resumos. VI SED. Ji-Paraná RO, 2013.

NEVES, Josélia Gomes; DIAS, P. ; SILVA, A. B. Estudantes indígenas em escolas urbanas: quando as diferenças culturais se transformam em violências institucionais. In: PACÍFICO, Juracy M.; BUENO, Lucas P.; GURGEL, Nair. (Org.). Qualidade na Educação e práticas pedagógicas: realidades e desafios.Brasil: PANDION, 2014, v. 001, p. 001-200. 
PACÍFICO, Juracy Machado; TAMBORIL, Maria Ivonete Barbosa Tamboril. Crianças indígenas, Escolas Urbanas e Violência Institucional: há lugar para trocas interculturais? In: NEVES, Josélia Gomes; PACÍFICO, Juracy Machado; BUENO, José Lucas Pedreira. (Orgs.). Universidade, Licenciatura e Interculturalidade: anúncio de aprendizagens na floresta. Pandion: Rondônia, 2013.

PÉREZ, C. L. V. Imagens Caleidoscópicas: as narrativas autobiográficas na formação das professoras alfabetizadoras. In: II SEMINÁRIO INTERNACIONAL: As redes de conhecimento e a tecnologia: imagens e cidadania, Rio de Janeiro, 2003. Disponível em: http:// www.lab-eduimagem.pro.br/frames Acesso: 23 set.2009.

QUIJANO, A. Colonialismo do poder e classificação social. In: SANTOS, B. S.; MENESES, M. P. (Org.). Epistemologias do Sul. Porto: Edições Afrontamento, 2009.

QUIJANO, A. Colonialidad del Poder y Clasificación Social. In: CASTRO-GÓMEZ, S. y GROSFOGUEL, R. El Giro Decolonial: Reflexiones para una diversidad epistémica más allá del capitalismo global. Bogotá: Siglo del Hombre Editores; Universidad Central, Instituto de Estudios Sociales Contemporáneos y Pontificia Universidad Javeriana, Instituto Pensar, 2007.

SANTOS, B. S.; MENESES, M. P. (Org.). Epistemologias do Sul. Porto: Edições Afrontamento, 2009, p. 73-117.

SANTOS, Vanúbia Sampaio dos; SECCHI, Darci. Estudantes indígenas em escolas urbanas de Rondônia: da omissão das políticas públicas à omissão do pertencimento étnico. Revista Reflexão e Ação, Santa Cruz do Sul, v.21, n. esp., p. 52-75, jan./jun.2013

SANTOS, Vanúbia Sampaio dos. Expressões identitárias no espaço escolar: um estudo com crianças indígenas de escolas públicas urbanas de Ji-Paraná, Rondônia. 2014. (Dissertação de Mestrado de Educação). Universidade Federal de Mato Grosso, 2014.

TEIXEIRA, Raquel F. A. As línguas indígenas no Brasil. In: LOPES DA SILVA, Aracy; GRUPIONI, Luís Donizete Benzi. (Orgs.). A temática indígena na escola: novos subsídios para professores de $1^{\circ}$ e $2^{\circ}$ graus. Brasília/MEC, 1995.

TAVARES, Manuel. Despensar as pedagogias coloniais e os seus pressupostos epistemológicos. 2011. Disponível em: <http:/www.uninove.br/marketing/viii_coloquio/pdfs/ Manuel_Tavares.pdf>.Acesso: 12 out. 2013.

WALSH, Catherine. Interculturalidade Crítica e Pedagogia Decolonial: in-surgir, re-existir e re-viver. In: CANDAU, Vera Maria. Educação Intercultural na América Latina: entre concepções, tensões e propostas. Rio de Janeiro: 7 Letras, 2009.

ZEICHNER, Kenneth M. Uma análise crítica sobre a "reflexão" como conceito estruturante na formação docente. Educ. Soc., Campinas, v. 29, n. 103, p. 535-554, maio/ago. 2008 535. Disponível em <http://www.cedes.unicamp.br> Acesso: 23 fev. 2015. 


\section{EXISTE UM LUGAR PARA AS ESCOLAS INDÍGENAS NO CENTRO- OESTE E NA AMAZÔNIA?}

\section{Darci Secchi (PPGE/UFMT)}

\section{Para situar o debate}

Os povos indígenas do Brasil já convivem com alguns tipos de escolas há vários séculos. Em cada época e em cada realidade específica, a escola assume diferentes ênfases no processo de colonização e/ou de construção da autonomia dessas sociedades.

$\mathrm{Na}$ era dos "descobrimentos", os debates acerca do lugar da escola indígena tiveram como cenário o confronto visual dos colonizadores com os habitantes das terras recém conhecidas. Discutia-se se esses seres naturais eram humanos e, tendo alma, se seriam educados na fé cristã, ou se deveriam ser eliminados ou escravizados. A controvérsia acerca da natureza humana dos indios resistiu à Bula Papal de Paulo III (1537) e desenhou os primeiros contornos do projeto colonizador no Brasil.

Para Clastres (1995), a contradição, que se alongou por mais de dois séculos, residia em reconhecer os índios como "criaturas de Deus" e, ao mesmo tempo, promover a sua captura e escravização. A saída formal encontrada para equacionar o dilema viria com a declaração (unilateral) de sua "antropofagia". Sempre que reconhecida a condição de "comedores de cristãos” os índios podiam ser combatidos e escravizados!

No imaginário europeu, residiu uma segunda percepção acerca dos índios: a de que seriam seres puros, simples, honestos e sem cobiça. Para Rouanet (1998), essa perspectiva, formulada pelo "quadrilátero do mito", isto é, pelas versões de Colombo, Pero Vaz, Américo Vespúcio e Claude Abbeville, seria maximizada no ideário europeu, especialmente por Montagne e Rousseau. 
Inversamente, no Brasil, predominou a percepção "desumanizada" dos indígenas, tidos como animais a ser combatidos sob pena de sermos devorados por eles. Vejamos essa breve descrição de Angyone Costa (1943), proposta para um livro didático e que, por sua clareza formal, dispensa maiores comentários:

$\mathrm{O}$ índio brasileiro era um animal forte, de corpo esguio, membros bem proporcionados, enxuto de carnes, sem deformidades produzidas pela gordura. O seu apetite entretanto não conhecia limites. Comia de tudo. Não havia animal que ele não encontrasse prazer em devorar... Comia do piolho à onça, do jacaré a outro índio. Comia pelo hábito de mastigar, de não estar com a mandíbula parada. (p. 69).

O ideário educacional jesuítico, que predominou no período colonial e se manteve presente com algumas variações até os nossos tempos, associou a escola à conversão dos "gentios". Seu projeto catequético avançou pela Ameríndia associado ao projeto de colonização em suas diferentes formas e expressões. A última missão jesuítica para índios no Brasil foi instalada em Mato Grosso e chamava-se Utiariti (uma antiga estação telegráfica de Rondon) e manteve-se em funcionamento até o ano de 1971. Por suas escolas passaram centenas de jovens e crianças de diversas etnias da região. Com o advento do Concílio Vaticano II e a proposição de novas estratégias de evangelização, a missão foi desativada e suas instalações disponibilizadas para usos diversos.

Os padres salesianos também se fizeram muito presentes no processo de escolarização indígena no Centro Oeste e, na Amazônia, ainda mantêm diversas missões religiosas para índios em diversos estados do Brasil.

Nas últimas décadas, porém, verificaram-se significativas mudanças no tratamento da temática educacional indígena. Os próprios índios entraram em cena para discutir políticas de escolarização e para exigir uma educação escolar voltada ao atendimento dos seus interesses. A educação escolar passou a ser vista como uma política pública, como um direito de cidadania. Nela, o reconhecimento à diversidade cultural (inédito na legislação), aos direitos específicos, à liturgia diferenciada para as suas escolas 
etc., foram considerados marcos (ou garantias) de um porvir de cidadania, de respeito e de valorização das sociedades indígenas.

Hoje já não se discute se os índios têm ou não têm alma, se devem ou não ser "civilizados", mas trata-se de admiti-los como cidadãos com direitos específicos e diferenciados. Mas a secular matriz colonial não foi totalmente superada. As atuais leis e regulamentos foram produzidos apenas com a audiência dos índios, ou contaram com a participação das comunidades. $\mathrm{Ou}$, dito de outra forma: a legislação admitiu a alteridade e tolerou a diferença, mas resguardou o direito discricionário de conceder direitos.

Ao mesmo tempo que se ampliou a tendência de delimitar e reduzir os assuntos indígenas aos cânones jurídicos e administrativos, viu-se proliferar as parcerias e cooperações entre o poder público e a militância indigenistas e acadêmica. Após a promulgação da Constituição de 1988, surgiu assim um novo discurso oficial e, com ele, o abandono das iniciativas integracionistas mais ostensivas.

Segundo Brand (1988), o avanço no arcabouço legal fez-se acompanhar de um crescente "confinamento geográfico e social" dos indígenas. Para ele, o esgotamento do modelo integracionista está diretamente ligado ao atual estágio da globalização e do neoliberalismo que encontrou como fórmula para solucionar o problema dos supérfluos o seu confinamento em favelas, acampamentos e reservas. Como o mercado não necessita mais a sua mão de obra, só lhes resta a condição de consumidores marginais, conclui. (p.7).

É, pois, nesse cenário, que os limites e as possibilidades das atuais escolas indígenas precisam ser configurados. Por isso, a pergunta recorrente no contexto do Centro-Oeste e da Amazônia: existe a possibilidade real de instituir escolas indígenas convergentes com os interesses e necessidades de suas comunidades? E, se sim, teriam elas apenas um lugar, apenas um modelo, um formato e um projeto educativo válido para todas as escolas da região?

\section{Uma breve retrospectiva histórica}

Como tivemos oportunidade de debater em um trabalho anterior (SECCHI, 2002). o modelo integracionista de educação para o indio no 
Brasil está associado à recorrência do binômio proselitismo doutrinário (religioso ou não) e à preparação para o trabalho. Assim atuaram as missões católicas, as escolas pombalinas, a educação positivista e, mais recentemente, os missionários e linguistas de diferentes confissões.

A partir da década de 50, insuflados pelos ares da modernidade e das novas relações internacionais do trabalho, passaram a ser incorporados nos países do chamado Terceiro Mundo novos instrumentos jurídicos e novos objetivos para a educação escolar das "populações tribais e semitribais". A Convenção 107 da OIT (1957) preconizou, dentre outros dispositivos, a garantia de educação em todos os níveis (art. 21); a realização de estudos antropológicos prévios à elaboração de programas escolares (art. 22); a alfabetização em língua materna seguida de educação bilíngue (art. 23); uma campanha de combate ao preconceito (art. 25) e a divulgação dos direitos e obrigações sociais e trabalhistas através de informações escritas nas próprias línguas (art. 26).

Somente uma década mais tarde esses dispositivos ingressaram no mundo jurídico brasileiro no texto da Constituição Federal de 1988. Mesmo assim, careciam de maiores explicitações, o que seria feito apenas em meados da década de 1990, com a publicação da Lei de Diretrizes e Bases da Educação Nacional (Lei 9394/96).

Ao longo dessas décadas de maturação jurídica e política, muitos atores compuseram o cenário da educação escolar indígena. $\mathrm{O}$ “indigenismo alternativo", pontuado na década de 1970, deu aporte para os primeiros movimentos indígenas, tidos como estratégias de oposição e superação do paradigma integracionista. As escolas oficiais foram vistas com cautela, quando não com desconfiança. Propunha-se em seu lugar a criação de escolas alternativas, mormente de acepção freireana, desatreladas do espaço do Estado e das instituições que o representavam.

$\mathrm{Na}$ década de 1980, a escola indígena ancorou-se no tripé organização indígena, reflexão acadêmica e militância indigenista, parceria que produziu uma vasta documentação, participou do processo constitucional e ostentou a chancela de ver as suas bandeiras contempladas na nova Carta. As articulações surgidas nesse contexto resultaram na organização de "Núcleos de 
Educação" ou "Núcleos de Estudos Indígenas" em diversos estados. Em alguns casos (como o de Mato Grosso), esses Núcleos deram origem aos atuais Conselhos de Educação Escolar Indígena, fóruns de representação paritária compostos por representantes indígenas e das instituições, que definem a política de educação escolar indígena nos respectivos estados.

Nesse período, realizaram-se também diversos Cursos de Capacitação de Professores e Encontros de Educação Indígena, eventos que deram suporte à organização dos atuais Programas de Formação de Professores Indígenas, desenvolvidos em Mato Grosso, no Acre e em outros estados.

Os direitos conquistados recolocaram em novas bases o antigo conflito entre o oficial e o paralelo, e as "relações perigosas" entre escola e estado passaram a ser vistas como "relações possíveis".

Os anos 1990 caracterizaram-se como um período de implementação do ideário gestado na década anterior. As novas palavras de ordem - "educação bilingue e intercultural", "currículos especificos e diferenciados", "processos próprios de aprendizagem" - precisavam ser materializadas no cotidiano das escolas. No entanto, nem o poder público estava preparado técnica e administrativamente para assumir essa tarefa, nem havia legislação específica que orientasse tal procedimento. No contexto desse "vazio normativo" e das pressões advindas das comunidades indígenas, dos grupos de apoio, de setores da academia e do próprio poder público, o governo federal e o MEC passaram a coordenar uma série de iniciativas que resultaram na atual arquitetura jurídica e administrativa para as escolas indígenas. Dentre as principais medidas destacaram-se:

a) a publicação do Decreto no 26/91 que transferiu da FUNAI para o MEC a responsabilidade pela coordenação, e aos estados e municípios pela execução das ações de educação escolar indígena;

b) a publicação da Portaria Interministerial no 559/91 e das Portarias MEC 60/92 e 490/93, instituindo e normatizando o Comitê Nacional de Educação Indígena, fórum que viria subsidiar a elaboração dos planos operacionais e as ações educacionais nos estados e municípios; 
c) a elaboração pelo Comitê Assessor e a publicação pelo MEC, em 1994, do documento "Diretrizes para a Política Nacional de Educação Escolar Indígena”, a partir do qual definiram-se os principais contornos do atendimento escolar indígena;

d) a sanção da Lei de Diretrizes e Bases da Educação Nacional (Lei 9394/96) que estabeleceu as normas específicas para a oferta de educação escolar para os poros indígenas;

e) a aprovação na Comissão de Constituição e Justiça do Senado Federal, em 6 de dezembro de 2000, da adesão à Convenção 169 da Organização Internacional do Trabalho, estabelecendo os direitos dos povos indígenas e tribais - PIT, dentre eles, o da educação escolar indígena em todos os níveis e nas mesmas condições que o restante da comunidade nacional;

f) a publicação da Lei Federal no 10.172 de 9 de janeiro de 2001, que trata da implementação do Plano Nacional de Educação e que estabeleceu mais de duas dezenas de objetivos e metas específicos para a educação escolar indígena.

Como vemos, multiplicaram-se e aperfeiçoaram-se os instrumentos jurídicos e administrativos concernentes à criação, implementação e reconhecimento das escolas indígenas. No entanto, as mudanças tiveram maior alcance nos aspectos operacionais e metodológicos e não significaram um rompimento conceitual que alterasse o modelo escolar anterior. Infelizmente, passados vinte anos de existência, o paradigma da escola especifica, diferenciada, bilingue e intercultural não avançou muito além da normatização formal e da ampliação do acesso. O impacto dos investimentos na formação de professores ainda não foi adequadamente avaliado, porém alguns indicadores permitem questionar a sua efetividade, especialmente se considerados os calendários letivos, os conteúdos trabalhados e a falta de acompanhamento e de continuidade da formação docente.

Muitas das atuais escolas indígenas mantêm e reproduzem a antiga escola colonial, porém, agora, fantasiada de novos atributos exigidos formalmente na legislação. Cabe, a nosso ver, especialmente no contexto 
do Centro-Oeste e da Amazônia, uma inquietante pergunta de natureza política e epistemológica: a educação escolar indígena teria esgotado as possibilidades de mudanças e de avanços com sua normatização e adjetivação pós-constitucional? Ou, dito de outra forma: o paradigma da escola especifica, diferenciada, bilíngue e intercultural representa a realização plena do ideário educacional dos povos indígenas?

\section{Relendo os discursos sobre o alcance das escolas indígenas}

Como vimos, o atual modelo de escola indígena teve a sua origem associada à Convenção 107 da OIT que, no século passado, definiu as relações internacionais do trabalho e ensejou incorporar as populações do "Terceiro Mundo" ao projeto liberal. Naquele contexto, e sem nenhuma maquiagem, propôs-se às escolas indígenas a função de agências padronizadoras de identidades e disponibilizadoras de mão de obra. Os programas escolares (e as suas adaptações em diferentes países) foram definidos anterior e exteriormente à participação das sociedades indígenas, limitando-as apenas ao seu cumprimento. Essa perspectiva foi assim expressa na LDB: "Os seus programas serão planejados com a audiência das comunidades indígenas" (Artigo 79, Parágrafo Primeiro, grifo nosso). Isso é, as agências externas (governos, academias, conselhos) planejarão os programas das escolas com a audiência indígena, e não o inverso: "as comunidades indígenas planejarão seus programas com a audiência do poder público, dos conselhos e da academia”.

A atual legislação reiterou sua origem colonial e deixou de contemplar uma premissa fundamental para a superação do modelo escolar integracionista, qual seja, a possibilidade de iniciativa das sociedades indígenas no processo de conceber, planejar, executar e gerir os seus programas educacionais. Manteve, assim, preservado o direito de outorgar direitos. Os índios permaneceram na qualidade de ouvintes e não de propositores de suas próprias políticas. Continuaram sendo espectadores ou atores coadjuvantes, sem direito a veto.

Um segundo aspecto problemático desse modelo de escola diz respeito a sua adjetivação como "escola bilíngue". 
Em sua primeira formulação, denominada "bilinguismo de transição", propunha-se assegurar "a transição progressiva da lingua materna ou vernacular para a lingua nacional ou para uma das linguas oficiais do pais". (OIT, Artigo 23, Inciso 2). Essa empreitada seria atribuída no Brasil aos missionários linguistas do Summer Institute of Linguistics - SIL, através de uma Portaria da FUNAI (75/72) que conferiu a essa agência norte-americana o status e foro "oficial" no que tratasse de assuntos linguísticos.

As críticas ao modelo de "transição progressiva" de uma língua para a outra (e não a utilização regular de ambas as línguas) não tardaram, por se tratar de uma repulsiva forma de etnocídio. Mesmo assim, perdurou por três décadas até ser substituída na legislação escolar por sua abordagem antagônica, a que denominamos "bilinguismo compulsório".

Se antes o aprendizado dos alunos dirigia-se no sentido de transitarem de uma situação monolíngue em língua indígena para uma situação de falantes de português, agora a situação se inverteria. Propunha-se que o bilinguismo fosse uma característica inerente às escolas indígenas, isso é, que estas fossem compulsoriamente bilíngues.

O documento Diretrizes para a Política Nacional de Educação Escolar Indígena, produzido pelo Comitê de Educação Escolar Indígena do MEC e lançado em 1994, não deixava dúvidas:

A escola indígena tem que ser parte do sistema de educação de cada povo, na qual, ao mesmo tempo em que assegura e fortalece a tradição e o modo de ser indígena, fortalecem-se os elementos para uma relação positiva com outras sociedades [...] Como decorrência da visão exposta, a educação escolar indígena tem que ser necessariamente específica e diferenciada, intercultural e bilíngue. (Grifo meu).

Parece óbvio que essa formulação generalista carece de sustentabilidade, embora não se questione a adoção do bilinguismo em situações sociolinguísticas diglóssicas. $\mathrm{O}$ seu ponto crítico reside na formulação como modelo tipológico obrigatório e único para as escolas indígenas. Não considerou o processo pedagógico de escolas cujos alunos indígenas são monolíngues em português, nem tampouco as situações de multiliguismo. 
Essa realidade, brilhantemente debatida por Silva (1994), longe de tratar-se de mera exceção, corresponde à realidade de uma expressiva parcela da atual população indígena brasileira. São inúmeros os casos em que "coexistem, em um mesmo contexto, mais de uma língua indígena e os casos em que a "língua indígena" é a própria língua nacional". Portanto, a escola verdadeiramente indígena não é necessariamente bilíngue, embora o bilinguismo possa ser atualmente recorrente em muitas escolas.

Ora, mais do que uma adjetivação emblemática para as escolas indígenas, o ensino bilíngue deveria constituir uma opção das comunidades e, como tal, poderia compor ou não o currículo e o cotidiano de suas escolas. Essa opção, porém, foi subtraída das comunidades e impingida como um direito estabelecido pela legislação. Mais uma vez, admitiu-se a diversidade domesticando a diferença, sem, contudo, abrir mão do direito de conceder direitos.

O mesmo ocorre com os dois adjetivos restantes: as escolas indígenas devem ser específicas e diferenciadas. Anunciados e cultuados como "novos avanços", esses "direitos compulsórios" ratificam a histórica perspectiva discriminatória de desqualificação das minorias étnicas e culturais. As escolas indígenas (como também as escolas rurais, ribeirinhas e das favelas) devem ser especificas e diferenciadas para "reproduzir os conhecimentos próprios", isso é, para reproduzir a negação cultural, a negação identitária e a negação da cidadania, elementos que compõem a essência do cotidiano de quem se sabe e se reconhece historicamente discriminado.

Talvez resida aí a razão de tanta dificuldade dos professores e lideranças indígenas em perceberem as escolas diferenciadas como algo positivo para os seus projetos. "Até agora só sabemos o que é diferenciado para pior e nunca para melhor", alerta um líder indígena xinguano.

Como se percebe, uma política de reconhecimento de direitos também pode ser etnocêntrica na medida em que os define exteriormente e os expressa em sua gramática própria. Porquanto, é possível avançar mais e

\footnotetext{
${ }^{1} \mathrm{O}$ autor destaca na Amazônia o multilinguismo no alto Rio Negro e como monolíngues em português, diversas comunidades do médio Solimões e baixo Madeira. O mesmo ocorre com diversas sociedades indígenas do Nordeste brasileiro.
} 
recompor o protagonismo indígena na definição dos respectivos projetos educacionais.

\section{$4 \mathrm{O}$ engodo da idealização das escolas indígenas}

Ao avaliar o movimento pela reestruturação curricular dos cursos de formação de professores nas últimas décadas, Brzezinski (1992) verificou que a escola idealizada para o início do novo milênio traria como principais atributos a formação de profissionais competentes, comprometidos, com postura ética, reconbecimento social e engajamento político.

O professor Newton Bryan (1996), por seu turno, enfatizou que a escola está intimamente vinculada ao projeto de desenvolvimento econômico e social do país. Para ele, no novo milênio, espera-se que a escola seja um espaço de veiculação de conhecimentos para a cidadania, mas também uma instância de qualificação para o mercado. Ou, dito de outra forma, a escola teria como principal função a formação para "os valores da modernidade de uma civilização apoiada nas ciências e nas técnicas modernas", além de propiciar "uma educação [...] que permita compreender e atuar no real, enquanto sujeitos políticos e produtivos que tenham conhecimento científico e consciência de seus direitos e deveres para dominar a natureza e transformar as relações sociais". (p. 55).

Em seu livro Cabeça bem feita, Edgar Morin (2000) questiona o "caráter profissional do ensino" no qual a escola tem apenas uma "função" e o professor uma "profissão". Para ele, a escola deve ter uma missão que requer domínios técnicos, mas também muita arte. Morin elenca uma série de atribuições que considera essenciais para a missão da escola:

- fornecer uma cultura que permita distinguir, contextualizar, globalizar os problemas multidimensionais, globais e fundamentais, e dedicar-se a eles; preparar as mentes para responder ao desafio que a crescente complexidade dos problemas impõe ao conhecimento humano; preparar as mentes para enfrentar incertezas que não param de aumentar, levando-as não somente a descobrirem a história incerta e aleatória do Universo, da vida, da humanidade, mas também promovendo nelas a 
inteligência estratégica e a aposta em um mundo melhor; educar para a compreensão humana entre os próximos e os distantes; ensinar a cidadania terrena, ensinando a humanidade em sua unidade antropológica e suas diversidades individuais e culturais, bem como em sua comunidade de destino, própria à era planetária, em que todos os animais enfrentam os mesmos problemas vitais e mortais. (p. 102-3).

Pablo Gentilli (1996) critica o que chama de "mcdonalização" das atuais escolas cuja lógica de funcionamento é comparada à de um fast food. Para dar vazão às necessidades modernas, a instituição produtora do saber escolar - a escola - funcionaria como qualquer outra organização produtora de mercadorias. Para conquistar os seus mercados, precisa configurar-se de modo a atender às especificidades e à diversidade desses nichos. Por isso,

o processo de preparação dos menus dos fast food e a confecção dos currículos escolares são muito similares: faz-se um diagnóstico das especificidades e das preferências da clientela, mas impõe-se um conteúdo universal, alterando-se apenas os aspectos formais que se fizerem necessários ou oportunos (p. 51).

Para ele, as escolas atuais apenas garantem as "funções de seleção, classificação e hierarquização dos postulantes aos futuros empregos (ou aos empregos do futuro). Para os neoliberais, nisso reside a função social da escola”. Como alternativa, propõe "descolonizar os atuais currículos", pois eles seriam "representações colonialistas e colonizadoras". (p. 52)

Como vemos por esses poucos exemplos, convivem no Brasil diferentes concepções acerca da instituição escolar. Não obstante seus diferentes enfoques, todas expressam uma realidade fundada em relações binárias (técnico-político; cidadania-mercado; técnica-arte e seleção-exclusão) com ênfase em apenas um dos termos do binômio. É esse dualismo excludente que caracteriza a nossa formação e as nossas ciências. Trazendo essa reflexão mais geral para a realidade das escolas indígenas, é fácil compreender a razão de termos tanta dificuldade de concebê-las para além dessa oposição: elas precisam ser específicas para não ser universais; 
precisam ser diferenciadas para não ser semelhantes; precisam ser bilíngues para não serem monolíngues e, finalmente, precisam ser interculturais para não serem monoculturalistas (como são as escolas coloniais oficiais).

Seria essa a única forma de conceber e de instituir a escola indígena no imaginário dos cientistas sociais, dos gestores públicos, dos indígenas e dos indigenistas? Será que os quatro adjetivos oficiais (que pretendem ser o "novo") são suficientes para garantir a diversidade, a adequação e os processos pedagógicos próprios de cada comunidade? Parece claro que não! É necessário qualificar essa versão única de escola indígena com ingredientes que espelhem mais amplamente a pluralidade de cada povo ou comunidade. É preciso avançar mais.

\section{Fustigando o modelo escolar oficial}

Uma excelente contribuição para avançar no debate e no alcance estratégico das escolas indígenas foi apresentada por Antonio Brand (1998), ao qualificar a educação escolar como uma ação dirigida para a emergência do outro, isso é, de povos com tradições culturais diversas da nossa e com projetos societários próprios. Para ele, os objetivos e os papéis que serão conferidos à escola devem ser definidos e redefinidos em cada realidade concreta.

Considera que a autonomia da escola, seja ela percebida em sua configuração legal e institucional, seja enquanto experiências históricas de enfrentamento do entorno regional ${ }^{2}$, deve ser a principal baliza a ser seguida. (Como sabemos, a noção de autonomia supõe um permanente processo de construção e reconstrução e o seu alcance reflete o embate das comunidades indígenas com o entorno regional).

Por isso, Brand chama atenção para o papel da escola como protagonista de um "amplo e vigoroso processo de quebra do silêncio histórico"

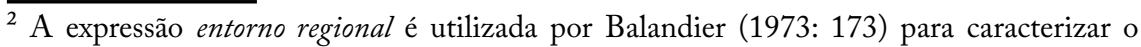
contexto regional dentro do qual vivem as populações nativas numa situação de dominação colonial. Para Brand (1998), caracteriza "aqueles setores da sociedade nacional que se situam e/ou têm interesses específicos junto às comunidades indígenas ou, ainda, que são objeto de interesse por parte das mesmas comunidades"(p.1) Inclui nessa categoria os órgãos públicos, representantes do Estado, as igrejas, os proprietários de bens imóveis etc.
} 
desencadeado em parceria com diferentes atores sociais, movimento indígena e outros segmentos organizados da sociedade.

Essa “irrupção histórica dos povos indígenas" que, segundo o autor, convergiu para o texto constitucional de 1988, deve ser consolidada com o atendimento de dois objetivos (ou desafios) principais: a) "ser um instrumento de afirmação étnica a serviço dos projetos de autonomia de cada povo ou comunidade e da sua coesão interna” e, b) capacitar individual e coletivamente cada pessoa, comunidade e povo indígena para o enfrentamento e definição dos espaços de participação no entorno regional. (BRAND, 1998, p.7). Como se percebe, suas proposições fustigam o âmago do paradigma oficial.

Um entendimento convergente ao de Brand é defendido também por Meliá (1997; 1998), Dias da Silva (1997), Maher (1996) e outros que estabelecem como parâmetros de análise o binômio "limites e possibilidades" da escola indígena.

Apontam para a tendência do afloramento de um modelo de escola indígena que estaria sendo definido pelos próprios índios. A esse novo modelo (ou fase) de implantação e desenvolvimento escolar, Dias da Silva denomina "autogestão indígena de suas escolas" uma vez que "os próprios povos indígenas são seus autores e protagonistas”(DIAS DA SILVA, p.24-5).

Nessa perspectiva, a escola indígena poderia ser assim caracterizada:

- uma nova instituição educacional, a serviço de cada povo;

- um instrumento de afirmação e reelaboração cultural;

- um elemento que contribui na conquista de espaço político;

- uma alternativa aos modelos anteriores de "escolas para os índios";

- um lugar onde se articulam os conhecimentos tradicionais e os novos conhecimentos;

- um espaço em que se disponibilizam informações decorrentes do contato; 
- uma possibilidade de construção de relações igualitárias, do reconhecimento e do respeito individual e social;

- um espaço de construção da contraideologia. (DIAS DA SILVA, p. 14 ss.; p. 204). ${ }^{3}$

Ivo Schroeder (1998), por seu turno, chama a atenção para as diferentes origens das escolas. Considera relevante perceber os múltiplos nascedouros de cada escola, seja por iniciativa do SPI, da FUNAI, das missões católicas, do Summer Institute of Linguistics, das prefeituras municipais, da rede estadual, de ONGs e mesmo das escolas autônomas, gestadas e geridas pelas próprias comunidades. Dentre algumas das iniciativas consideradas "exemplares", cita as escolas dos Tapirapé, Rikbaktsa e Myky, pois "lograram levar à prática uma nova concepção de escola que, além de incorporar a língua materna, conseguiram construir um currículo a partir da realidade cultural e dos conhecimentos específicos de cada povo.” Para Schroeder, a escola indígena adequada é aquela que

recupera a pedagogia da vida cotidiana, valoriza os meios disponíveis, parte da história e dos mitos, [...] as comunidades assumem o papel fundamental na definição de ritmos, calendários, palavras geradoras e, sobretudo no espaço que concedem à escola. (p. 40).

Lembra, porém, que a escola é uma instituição estranha ao modo tradicional de ensinar e que doravante passará a fazê-lo, "trazendo novos conteúdos, novos símbolos, novas formas de transmissão que desarticularão a tradicional sabedoria milenar, subvertendo-a e relativizando a sua importância." O autor considera também que o fracasso de diversas iniciativas de escolarização indígena pode ser lido como um "sinal de resistência velada diante de uma nova ordem de coisas" que lhes é imposta. (p. 45).

Por fim, destaco a proposição de escola indígena formulada por Mariana Leal Ferreira (1992) para quem a educação escolar é um processo "interpretado e remanejado de diferentes formas pelas sociedades

\footnotetext{
${ }_{3}$ Completando esse elenco, Silva e Azevedo (1994) dão ênfase aos "projetos de futuro" e Secchi (1997) e outros, aos "projetos societários".
} 
indígenas". Tanto a dominação exercida pela escola quanto o seu perfil tipológico são específicos e distintos. Cada povo desenvolve alternativas de ação e implementa dinâmicas próprias para fazer frente à situação de contato. A escola aparece como um dos instrumentos a serem acionados, ora como espaço de construção de identidades étnicas, ora como instância de interlocução com a sociedade não índia. Para ela, são os índios que têm o "direito de definir as próprias concepções de educação escolar, de acordo com os processos tradicionais de aprendizagem e os interesses de cada sociedade". (p.179).

Como vemos, existe boa convergência de proposições nos discursos citados. Ainda que os enfoques priorizem diferentes aspectos (metodológicos, políticos, culturais etc.), existe um relativo consenso quanto à necessidade de que os principais interessados - as sociedades indígenas - decidam o projecto de escola que lhes convém.

Essa postura de salvaguarda da autonomia enquanto um valor, ou enquanto um direito primordial das sociedades indígenas, se contrapõe às antigas práticas impositivas e mesmo ao atual discurso oficial pós-constitucional. Enquanto uns remetem as decisões e o controle escolar às instâncias internas das comunidades, outros buscam o aval de suas proposições na audiência das comunidades ou na representação paritária entre "índios e não índios". (SECCHI, 2000, p. 71). Ao evocar a necessidade de "diretrizes", "referencial", "parâmetro", "diagnóstico" e toda a sorte de formalização normativa, o Estado transforma as orientações gerais em verdadeiras obrigações cujo descumprimento alija as comunidades, etnias, ONGs e até mesmo o poder público local, dos benefícios estendidos às escolas regulares. ${ }^{4}$

De outra parte, as bandeiras da autogestão plena e da autonomia desprovida de dependências se assemelham não podem ser apenas verdades militantes (CAVALCANTI, 1999), que desconsideram a realidade institucional brasileira - o marco nacional - com suas múltiplas injunções. Como em qualquer contrato social, o "pacote educacional" impõe (ou deixa implícitas) as condições de vigência, execução e avaliação. Por isso, é importante

\footnotetext{
${ }^{4}$ Especialmente na disponibilização de recursos financeiros e na certificação e/ou titulação de cursos realizados.
} 
“negociar" bem os seus termos, uma vez que expressarão a relação de maior ou menor autonomia; de maior ou menor protagonismo indígena.

Nesse sentido, nos parece essencial que as escolas indígenas garantam o controle sobre três instâncias estratégicas na relação com o estado nacional:

a) Controle sobre os recursos da escola, assegurando o seu fluxo sistemático e permanente para a manutenção e o livre exercício das atividades;

b) Controle sobre a organização da escola, de forma a inseri-la adequadamente nos espaços físicos e culturais e nas temporalidades das aldeias

c) Controle sobre os saberes da escola, articulando os antigos e os novos conhecimentos e os utilizando no cotidiano sociocultural.

O controle sobre o acesso, a administração e aplicação dos recursos externos; sobre a organização escolar e curricular e sobre a formação de professores é que definirá, a nosso ver, o presente e o futuro das escolas indígenas.

Mais do que especifica, diferenciada, bilingue e intercultural, a escola terá um lugar estratégico para os povos indígenas do Centro-Oeste e da Amazônia adequada quando for incorporada à sua comunidade e the propiciará o controle crescente sobre si e sobre outros elementos culturais definidos por cada povo. Para tanto, dentro do marco nacional que caracteriza a realidade brasileira atual, deverá ser uma instituição fundada no convívio dialógico com múltiplos protagonistas, especialmente com o poder público e com as respectivas comunidades.

\footnotetext{
5 Como ensina Foucault (1987), é distribuindo os indivíduos nos espaços, determinando seus respectivos lugares, classificando-os, decidindo sobre a forma de aproveitamento de seu tempo, articulando seus gestos e os movimentos de seus corpos aos objetos escolares, determinando sequências de complexidade crescente, exercitando-os e examinando-os em cada etapa, que se processa o disciplinamento dos sujeitos e que se produzem as verdades.
} 


\section{Referências}

BALANDIER, Georges. As dinâmicas sociais - sentido e poder. S. Paulo - Rio de Janeiro: Difel, 1976.

BATALLA, Guillermo Bonfil. La teoría del control cultural en el estudio de procesos étnicos. Ciudad de México: Papeles de la Casa Chata n. 3,1987.

BRAND, Antonio. O impacto da perda da terra sobre a tradição Kaiowá/Guarani; os difíceis caminhos da Palavra. Tese de doutorado, Porto Alegre: PUC/RS, 1998.

BRYAN, Newton. Desafios do ensino tecnológico. In: BICUDO \& SILVA JUNIOR (Orgs). Formação do educador - dever do Estado, tarefa da Universidade. v. 2 e 3. S. Paulo: Editora Unesp, 1996.

BRZEZINSKI, Iria. Trajetória do movimento para as reformulações curriculares dos cursos de formação de profissionais da educação: do Comitê (1980) à Anfope (1992).

CASTORIADIS, Cornelius. A instituição imaginária da sociedade. S. Paulo: Paz e Terra, 2000.

CAVALCANTI, Ricardo A. Presente de branco, presente de grego? escola e escrita em comunidades indígenas do Brasil Central. Dissertação de Mestrado, Rio de Janeiro: PPGAS - Museu Nacional-UFRJ, 1999.

CHARBONNIER, Georges. Arte, linguagem, etnologia. Entrevista com Lévi-Strauss, trad. Nícia Adan Bonatti. Campinas: Papirus, 1989.

COSTA, Angyone. Ideologia. Rio de Janeiro: Livraria Editora Zelio Valverde, 1943.

DIAS DA SILVA, Rosa Helena. A autonomia como valor e a articulação de possibilidades: um estudo do movimento dos professores indígenas do Amazonas, Roraima e Acre, a partir dos seus encontros anuais. Tese de doutoramento, S. Paulo: Programa de Pós-Graduação em Educação, USP, 1997.

FERREIRA, Mariana K. Leal. Da origem dos homens à conquista da escrita: um estudo sobre povos indígenas e educação escolar no Brasil. Dissertação de mestrado, S. Paulo: Programa de Pós-Graduação em Antropologia Social, USP, 1992.

FOUCAULT, Michel. Vigiar e punir. 7.ed. Petrópolis: Vozes, 1987.

GENTILLI, Pablo. A mcdonalização da escola: a propósito de "consumindo o outro". In: COSTA, Marisa V. Escola básica na virada do século: cultura, política e currículo. S. Paulo: Cortez, 1996.

MEC. Diretrizes para a política nacional de educação escolar indígena. Cadernos de educação básica, série institucional, v. 2. Brasília: MEC, 1993. 
Plano decenal de educação para todos - 1993-2003. Brasília: MEC, 1994.

MELIÁ, Bartomeu. Bilinguismo e escrita. In: D’ANGELIS \& VEIGA (Orgs). Leitura e escrita em escolas indígenas. Campinas: Mercado de Letras, 1997.

Desafios e tendências na alfabetização em língua indígena. In: EMERI, L. \& MONSERRAT, R. (Orgs). A conquista da escrita. S. Paulo/Cuiabá: Iluminuras/OPAN, 1989.

MORIN, Edgar. A cabeça bem feita - repensar a reforma, reformar o pensamento. Rio de Janeiro: Bertrand Brasil, 2000b.

OIT - Organização Internacional do Trabalho. Pueblos indígenas y tribales: guía para la aplicación del convenio núm. 169 de la OIT. Genebra: OIT, 1996.

QUIJANO, Aníbal. Modernidad, identidad y utopía en América Latina. Lima: Sociedad y Política Ediciones, 1988.

ROUANET, Sérgio Paulo. O bom e o mau selvagem. In: Brasil 500 anos: a outra margem do ocidente. S. Paulo: Itaú Cultural/Fundação Nacional de Arte, 1998.

ROUSSEAU J.-J. Discurso sôbre as ciências e as artes e sôbre a origem e os fundamentos da desigualdade entre os homens. $(1749 ; 1753)$ Trad. Maria Lacerda de Moura, Biblioteca Clássica, v. XII, S. Paulo: Atena Editora, s/d.

SCHROEDER, Ivo. O significado da escola em sociedades indígenas. Revista de educação pública. Cuiabá, v.7.n.12. Editora Universitária da UFMT, 1998.

SECCHI, Darci. Cem anos depois: escolas indígenas em Mato Grosso. In: CEI/MT. Urucum jenipapo e giz: a educação escolar indígena em debate. Cuiabá: CEI/MT, 1997.

SECCHI, Darci. Escolas indígenas e currículos interculturais: avanços e desafios. In: Alípio Casali e Suely Castilho (Orgs.) Diversidade na educação: implicações curriculares. Educ Editora da PUC-SP, 2015.

SEDUC. Projeto Tucum: programa de formação de professores indígenas para o magistério. Cuiabá: Secretaria de Estado de Educação, 1995.

A construção coletiva de uma política de educação escolar indígena para Mato Grosso (versão preliminar). Cuiabá: SEDUC/CAIEMT/CEI/MT, 2001.

SILVA, Tomaz Tadeu da. Identidades terminais: as transformações na política da pedagogia e na pedagogia da política. Petrópolis: Vozes, 1996.

SILVA, Márcio F. da. A conquista da escrita. Campinas: Unicamp, 1994. 


\section{AS CONTRIBUIÇÕES DOS ESTUDOS CULTURAIS PARA OS ESTUDOS COM CRIANÇAS INDÍGENAS}

Adir Casaro Nascimento(PPGE/UCDB)

Rozane Alonso Alves (UFAM)

\section{Introdução}

Pelas relações que as autoras estabelecem com pesquisas voltadas às crianças indígenas de Rondônia e Mato Grosso do Sul - cada uma com contextos indígenas específicos - e pelas aproximações com o campo dos Estudos Culturais, é que a proposta deste escrito se pauta em problematizar as articulações possíveis e as contribuições dos Estudos Culturais na pesquisa com crianças, a ressignificação dos conceitos de infância, bem como as novas percepções sobre infância e criança indígena no campo dos estudos das culturas infantis indígenas.

Busca, também, discorrer acerca da produção da pesquisa, entendendo a multiplicidade de olhares produzidos pelas pesquisadoras com crianças indígenas, no âmbito da produção dos dados e nas possibilidades do pesquisar. A intenção é discutir as limitações, aproximações, distanciamentos, os deslizes que produzem os caminhos metodológicos e as percepções desses caminhos, enquanto campo de experiências, a partir dos diálogos com os Estudos Culturais.

É interessante apontar que tais problematizações também se articulam com as novas possibilidades de olhar a criança indígena como sujeito que pesquisa e produz a pesquisa. Se, ao nos posicionarmos como sujeitos que, ao olhar a pesquisa com crianças, neste caso indígena, as percebem como sujeitos-pesquisadores, acabamos por entrar em jogo das palavras, dos discursos ou, como Walter Benjamin (2002), no jogo das experiências que quase sempre se constituem pela voz do adulto que a vivenciou. "Travamos nossa luta por responsabilidade contra um ser mascarado. A máscara 
do adulto chama-se experiência" (p.21). Os escritos de Benjamin se atentam a descrever a voz que constrói a verdade sobre as vivências das crianças, que as autorizam a falar, a viver.

Estamos também falando de culturas que vivenciam e experienciam as crianças sob a ótica de outras relações. Mas, ao trazer Benjamin para esta discussão, o fazemos por entender que quem fala dessas crianças e das relações que elas estabelecem com suas culturas, com seus pares, no nosso caso, tem sido o adulto não indígena e, neste momento, posicionar-se como o sujeito outro que tenta minimamente, no contexto da pesquisa, "escutar o outro sem pretensão de compreendê-lo [...] pois a compreensão, se não vier acompanhada do reconhecimento de que há coisas incompreensíveis, resultará no retorno da mesmidade e da asfixia da diferença”. (BACKES, NASCIMENTO, 2011, p. 30).

Posicionadas sobre qual lugar ocupa a criança indígena (e demais) no campo da pesquisa, na produção dos dados e nas possibilidades metodológicas, passamos agora a discutir teoricamente o que estamos chamando de Estudos Culturais e suas contribuições neste pesquisar com crianças indígenas de Rondônia e Mato Grosso do Sul.

\section{Estudos culturais e crianças indígenas: possibilidades teórico-meto- dológicas}

"Os Estudos Culturais jamais constituíram, e tampouco constituem, hoje, um conjunto rigidamente articulado de ideias, concepções e pensamento" (KIRCHOF; WORTMANN; COSTA, 2015, p. 7). Mas se apresentam como um campo de investigação que transita nas instabilidades da própria investigação e, ao mesmo tempo, se constitui com espaço de "produção de novos saberes acerca dos modos como processos socioculturais estão implicados na construção de nossas concepções sobre o mundo [...]"(KIRCHOF; WORTMANN; COSTA, 2015, p. 7). As instabilidades, a produção de novos saberes, constituem também os sujeitos pesquisadores e pesquisadoras por meio da escrita que se produzem nos (des)caminhos 
da pesquisa, o "si mesmo(a)" e os dos outros, no caso o "si" das crianças indígenas.

Transitar entre diferentes campos teóricos buscando apoio conceitual que desse conta de perceber as crianças indígenas como sujeitos atuantes dos procedimentos metodológicos, ou mesmo que possibilitasse a abertura de novas fontes teóricas, se tornou foco dos pesquisadores e pesquisadoras de culturas infantis indígenas

Apoiando-se nessas discussões, Aracy Lopes da Silva e Angela Nunes (2002), ao tratarem das contribuições da etnologia indígena brasileira, lembravam as poucas referências no âmbito das pesquisas com crianças indígenas e o quanto se faziam emergentes escritos específicos que as abordassem como sujeitos que também pesquisam.

Outros campos teóricos, como os estudos denominados sociologia da infância com foco para os pesquisadores/as portugueses e norte americanos, iniciaram, especificamente na década de 1990, estudos mais aprofundados sobre o conceito de infância e de criança. $\mathrm{Na}$ década de 1970, Philippe Ariès iniciou as discussões sobre a história da criança e da família que acabaram levando o nome de seu livro. Em suas discussões, Áries tratou as crianças como sujeitos únicos, universais, deixando de problematizar as especificidades relacionadas aos contextos, às culturas, entre outras. Mesmo com a universalidade abordada por Áries, sua contribuição para o surgimento de novos diálogos sobre as infâncias tornou-se imprescindível.

A antropologia tornou-se também uma das possibilidades para se discutir as culturas infantis indígenas. Autores como Nunes (2002), Cohn (2005) Silva (2002), Sobrinho (2009), em seus trabalhos, articulam a Sociologia da Infância e a Antropologia para discutirem seus trabalhos com as crianças indígenas.

Fazer essas articulações entre campos conceituais e, ao mesmo tempo, problematizar as discussões que permeiam ambas as disciplinas, produzindo novas reflexões que irão transitar e/ou produzir novos diálogos, são questões constantes nos Estudos Culturais, uma vez que há "novos terrenos com práticas e produções cujas aproximações com a teoria são variadas e, 
sobretudo, incomuns, as quais, por sua diversidade e constantes transformações, ainda não puderam ser mapeadas" (KIRCHOF; WORTMANN; COSTA, 2015, p.9).

Mas é a partir desse campo teórico que novas possibilidades metodológicas são problematizadas, pois essas possibilidades são transitórias e a própria provisoriedade do tema de pesquisa a desestabiliza. Os Estudos Culturais buscam discutir os métodos e metodologias como orientações que precisam ser revisitadas sempre que o/a pesquisador(a) pensar/estar (n) o campo empírico, (n)as relações que ele ou ela estabelece com os sujeitos envolvidos, e a própria relação que os sujeitos participantes da pesquisa estabelecem com a proposta da pesquisa.

Pensar os métodos e os procedimentos metodológicos de produção de dados como práticas investigativas que devem contextualizar os sujeitos, suas relações, experiências, movimentos, identidades, culturas, negociações, articulações, entre outras questões que se fizerem relevantes, a partir do campo empírico, são problematizações presentes no campo teórico em tela. É interessante entender que contextualizar não se restringe a descrever um contexto ou uma relação, mas de aproximar sujeitos, culturas, e visibilizar as relações dos sujeitos com e sobre seu contexto. Para aqueles que pensam essas questões apenas como "espaço e tempo absolutos e abstratos", contextualizar torna-se sem sentido (COSTA, 2015, p. 65).

Essa transitoriedade metodológica no pesquisar com crianças indígenas permite aos pesquisadores e pesquisadoras problematizar os deslizes, os escorregões nas escritas, nas leituras, nas pesquisas, nas análises. O escorregar, o deslizar ${ }^{1}$, além de criar a possibilidade de viver nas fronteiras ${ }^{2}$, constitui também condições desses sujeitos pesquisadores de

\footnotetext{
${ }^{1}$ Hall (2005) conceitua deslizar a partir do campo da linguagem, propondo que não há um significado nas/para as "coisas", as "coisas" são contingenciais, movediças, é produzida a partir do tempo, do momento, do uso dos discursos como estratégia temporal.

${ }^{2}$ Viver nas fronteiras ou entre fronteiras não se constitui como a demarcação/cercamento de um espaço, contexto, mas como a transposição de sujeitos e culturas que vivem entre-lugures (local intersticial). Para Bhabha, "fronteira se torna o lugar a partir do qual algo começa a se fazer presente [...] ponte que reúne enquanto passagem que atravessa” (1998, p.24).
} 
olhar as suturas ${ }^{3}$ dos sujeitos com quem se pesquisa, neste caso, as crianças indígenas.

É preciso entender que os Estudos Culturais se constituem, enquanto campo teórico, móvel, flexível, é articulador de ideias e conceitos que problematizam os sujeitos e sua multiplicidade, seus contextos, significados, representações ${ }^{4}$, identidades, enfim, culturas, para que, desse modo, possa pensar a criança indígena contemporânea, seus modos de relacionar-se nesses contextos.

A exploração desse novo território (ou será um velho território sob novas explorações?) produz novas direções, novas possibilidades, novas formas de pensar a pesquisa com crianças, uma vez que, ao produzir dados, produzem-se também representações dessas crianças indígenas, de suas culturas e das relações que elas estabelecem entre cultura e si mesmas.

As inconstâncias, os deslizes, a não concretude/fixidez dos dados produzidos nos permitem problematizar, por exemplo: quais sujeitos produzo perante as representações que constituo a partir das minhas escolhas teórico-metodológicas? Que significados atribuímos às crianças indígenas no que se refere às "posições de sujeitos" delas em relação ao contexto que pesquiso? Que atenção, qual olhar circula em nossas percepções empíricas em relação às crianças indígenas com quem pesquisamos? Como elas nos "produzem e como nós, como sujeitos, podemos ser posicionados nessas 'posições de sujeitos"' no pesquisar, na produção de dados? (WOODWARD, 2012, p. 17).

Os conflitos, as tensões da pesquisa também são produzidas no interior das relações que são estabelecidas entre pesquisador(a) e crianças indígenas (seus contextos, seus significados, as representações que atribuem,

\footnotetext{
${ }^{3} \mathrm{O}$ fato de que projetamos a "nós próprios" nessas identidades culturais, ao mesmo tempo que internalizamos seus significados e valores, tornando-os "parte de nós”, contribui para alinhar nossos sentimentos subjetivos com os lugares objetivos que ocupamos no mundo social e cultural. A identidade, então, costura (ou, para usar uma metáfora médica, "sutura") o sujeito à estrutura. Estabiliza tanto os sujeitos quanto os mundos culturais que eles habitam, tornando ambos reciprocamente mais unificados e predizíveis (HALL, 2005, p.12).

${ }^{4}$ Nossas identidades são produzidas pelos sistemas de representação. As tensões e conflitos cotidianos que constituem nossas identidades também são. A representação "inclui práticas de significação e os sistemas simbólicos por meio dos quais os significados são produzidos, posicionando-nos como sujeito. É por meio dos significados produzidos pelas representações que damos sentido à nossa experiência e àquilo que somos"(WOODWARD, 2012, p.17-18).
} 
seus olhares, suas identidades, as representações que as crianças produzem a seu respeito).

Os Estudos Culturais não constituem uma teoria fixa, rígida, mas um campo de articulação, de transgressão, de subversão, uma vez que seu campo de investigação, discussão, problematização e de análise atua sobre contextos e sujeitos múltiplos, e suas verdades são sempre provisórias.

Ressaltamos que os/as autores(as) do campo dos Estudos Culturais apontam que, mesmo os Estudos Culturais sendo um campo plural em que múltiplas vertentes e disputas são constitutivas, isso não significa que esse campo não possa estabelecer suas especificidades.

As articulações, as possibilidades teórico-metodológicas desse campo permitem a produção de narrativas outras nos discursos sobre os estudos das culturas infantis. Se, no âmbito dos discursos constituídos como verdade, por meio do eurocentrismo/ocidentalismo sobre a criança e a forma de se viver a(s) infância(s) produziam/produzem narrativas homogeneizantes, estereotipadas e generalizantes, as concepções e percepções dos Estudos Culturais provocam o pesquisador(a) frente ao campo empírico e negocia com os conceitos que sustentam seus estudos, ele(a) desestabiliza essas narrativas, problematizando-as e constituindo um espaço de discussões outras, sobre as formas de ser das crianças.

Apontamos que tais discussões outras, para além das possibilidades de problematizar as crianças, podem também trazer para este trabalho as traduções, negociações e transgressões (BHABHA, 1990, 1998) dessas formas de ser - criança-sujeito-indígena, vivenciados e experienciados por ela.

Os Estudos Culturais é um projeto político não apenas por construir uma história política do presente, mas por fazer isso de um modo particular, radicalmente contextual, para evitar os mesmos universalismos e essencialismos que caracterizaram as práticas dominantes de produção do conhecimento, os quais têm contribuído, mesmo que não intencionalmente, para o estabelecimento de relações de domínio, desigualdade e sofrimento que os Estudos Culturais desejam transformar (BARBERO, 2004, p. 39). 
Nas palavras de Hall, "Com efeito, fazer com que os Estudos Culturais colocassem em sua agenda as questões críticas de raça, da política racial, a resistência ao racismo, questões críticas da política cultural, constitui uma ferrenha luta teórica" (HALL, 2011, p. 197).

Pensar a partir dos escritos de Stuart Hall (2011), referentes às questões críticas que os Estudos Culturais abordam em meio as suas problematizações, nos remete a pensar as múltiplas infâncias e crianças.

Por sob rasura a escrita, a problematização, aquilo que busca empiricamente, permite ao pesquisador(a) tentar mostrar os acontecimentos, os sujeitos, os discursos, as narrativas como elas são, como estão sendo produzidas as relações sociais do hoje, do presente. Em relação à pesquisa, essas problematizações não devem ser apenas na perspectiva do(a) pesquisador(a), mas no sentido de que o sujeito-pesquisador(a) deve estar atento às nuanças, às relações, ao contexto que se pesquisa.

Assim, o(a) investigador(a) não vai transformar uma determinada realidade, um determinado contexto, um determinado sujeito ou grupo social, mas poderá discutir, articular, questionar, fazer emergir a pluralidade das questões pesquisadas, não como conclusivas, uma vez que os Estudos Culturais não têm a priori a conclusão. Nesse sentido, os Estudos Culturais tentam escapar da delimitação.

É em relação à fuga da delimitação que talvez os estudos com crianças vêm buscando problematizar como se constitui a infância/criança e como as identidades das crianças vão sendo produzidas perante os seus modos de ser infantil na contemporaneidade. Nesse sentido, passamos agora a discutir algumas dessas problematizações.

\section{A pesquisa com crianças indígenas no contexto de Mato Grosso do Sul e Rondônia a partir do campo dos Estudos Culturais}

O trabalho ${ }^{5}$ de dissertação de mestrado da professora indígena Terena Edineide Bernardo Farias buscou problematizar os "primeiros impactos sofridos pela criança indígena Terena no primeiro contato escolar

\footnotetext{
${ }^{5}$ Ressaltamos que os trabalhos se encontram disponíveis no banco de dissertações do Programa de Pós-Graduação em Educação da Universidade Católica Dom Bosco - UCDB.
} 
ao ser inserida na pré-escola, analisando o diálogo estabelecido entre os saberes tradicionais familiares e os novos saberes da educação escolar indígena, o processo de socialização da criança indígena terena da Aldeia Buriti no contexto familiar, bem como a importância dos processos próprios de aprendizagem dessa criança indígena antes de chegar ao espaço escolar”. A presente pesquisa foi desenvolvida na Escola Municipal Indígena Alexina Rosa Figueredo, na aldeia indígena Buriti, da etnia Terena, localizada no município de Dois Irmãos do Buriti, em Mato Grosso do Sul.

A tessitura deste escrito esteve pautada no campo dos Estudos Culturais, tendo como premissa metodológica a etnografia bem como entrevistas dialogadas com os anciões da aldeia Buriti, com professores, pais de alunos e alunos da pré-escola da Escola Municipal Indígena Alexina Rosa Figueredo, da Aldeia Buriti. A etnografia, no contexto deste trabalho, funcionou como linha articulatória entre modos de ser criança na contemporaneidade e as ressignificações produzidas no contexto do povo Terena da aldeia Buriti.

Ao fazer a leitura do trabalho de Farias (2015), percebemos como as crianças se tornam protagonistas no próprio contexto da escrita da dissertação, pois as narrativas conduzem a autora e a autoriza experienciar novas possibilidades de ver a "infância" e ao mesmo tempo contar suas experiências de ser criança.

Farias coloca sob rasura os modos de ser criança Terena no contexto da aldeia Buriti para que ela, como professora e pesquisadora Terena, possa problematizar as suturas das crianças de sua comunidade e suas ressignificações, articulações e negociações no âmbito da escola. Questiona com as crianças os processos de socialização delas ao ingressarem no espaço escola e como elas são produzidas nesse contexto.

Para perceber essas suturas, esses modos de ser criança no espaço da escola, a autora discute como elas transitam nesse espaço e como elas articulam ser Terena, ser criança e ser estudante. Ao narrar essas identidades infantis Terena, Farias aponta que "a criança indígena Terena assume várias identidades: ouvindo os mais velhos na roda do mate, ela se posiciona como ouvinte; nas brincadeiras, com suas aventuras; e na escola, adota uma 
postura para ouvir e aprender" (2015, p. 58) e busca nos escritos de Hall (2005, p. 13) problematizar que a "identidade é definida historicamente, e não biologicamente. $\mathrm{O}$ sujeito assume identidades diferentes em diferentes momentos, identidades que não são unificadas ao redor de um 'eu' coerente". Farias aponta ainda que "a criança indígena Terena possui seu próprio aprendizado, mesmo antes de frequentar o ambiente escolar, mas que, a partir deste momento, passa a agregar novas formas da construção de saberes, já que possui uma cultura híbrida, através da orientação da educação escolar” (2015, p. 59).

O trabalho da professora Kaiowá Elda Vasque de Aquino, intitulado Educação Escolar Indígena e os processos próprios de aprendizagens: espaços de inter-relação de conhecimentos na infância Guarani/Kaiowá, antes da escola, na Comunidade Indígena de Amambai, Amambai - MS, se aproxima das discussões do trabalho de Farias (2015) na medida em que se propõe a conhecer melhor a criança Guarani/Kaiowá antes de ir à escola, e observar/ descrever como se dão as suas aprendizagens, tendo em vista a compreensão dos seus processos próprios de aprendizagens e as suas interações estabelecidas com o cotidiano e seu entorno. Ressaltamos que o trabalho em tela se encontra disponível no banco de dissertações do Programa de Pós-Graduação em Educação da Universidade Católica Dom Bosco - UCDB.

Aquino (2012) ficou atenta aos modos como as crianças produzem seus processos próprios de aprendizagem no contexto Guarani/Kaiowá, numa perspectiva da cultura tradicional. Buscou entender ainda como é ser criança na comunidade, diante de todas as informações que vão chegando, bem como compreender a infância Guarani/Kaiowá e os seus modos de aprendizagem, além de perceber como é o trânsito entre essas fronteiras, nos entre-lugares (BHABHA, 2007). E para dar conta dessas suturas, a autora buscou apoio na etnografia pautada nas discussões dos Estudos Culturais e também nas entrevistas e fotografias como mecanismo para a produção de dados.

Com esses instrumentos de produção de dados, Aquino (2012, p. 48) narra como os conhecimentos são produzidos e dialogados no contexto do povo Guarani/Kaiowá da aldeia Amambai, e segue nos provocando a 
pensar a relação das crianças com a comunidade e seus saberes a partir da relação que elas estabelecem com os mais velhos e com seus pares, pois

[...] os conhecimentos são transmitidos pelos mais velhos e até pelas outras crianças com quem convivem, seja na família ou com os parentes que estão no entorno. A educação a vida vai acontecendo no dia a dia e em vários locais: seja na beira do fogo, da madrugada, no amanhecer, quando os conselhos de nossos avôs tinham mais sucesso, porque nosso deus usava a boca deles para repreender os espíritos da desobediência.

Aquino nos provoca a problematizar as negociações e os atravessamentos das crianças indígenas da aldeia Amambai frente aos novos saberes e sujeitos que circulam com elas em seus contextos de vivências, no viver na fronteira, nos entre lugares da cultura. "As crianças sabem que precisam ressignificar no mundo moderno os conceitos antigos, fazer uma difusão de conhecimentos e sabedoria para poder continuar mantendo o 'ñandereko tee yvyarigua"' (nosso jeito de viver aqui no mundo) (2012, p. 105).

Encontramos no trabalho de dissertação de mestrado de Claudemiro Pereira Lescano, intitulada TAVYTERÃ REKO ROKYTA: os pilares da educação Guarani Kaiowá nos processos próprios de ensino e aprendizagem, um "mundo vasto que existe na cosmovisão do povo Kaiowá, composta de valores, elementos culturais, processos próprios de ensino e aprendizagem, bem como a inserção das crianças Kaiowá para manutenção, ressignificação e fortalecimento de identidade" (2016, p. 5). O pesquisador indígena Guarani Kaiowá, apoiado no campo dos Estudos Culturais, aponta que sua proposta metodológica se pautou na investigação etnográfica e autobiográfica e que foi desenvolvida através de observação, visitas e conversas com os sábios, rezadores e crianças guarani e Kaiowá.

Os escritos de Lescano (2016) nos permitem perceber a produção das identidades das crianças Guarani Kaiowá pela cosmovisão de seu povo. $\mathrm{O}$ pesquisador nos mostra, em suas narrativas e nas narrativas dos participantes da pesquisa, como são percebidos os comportamentos e envolvimentos das crianças no contexto da comunidade, e seu desenvolvimento enquanto bom (ou não) Guarani Kaiowá ao longo da vida. A relação entre o pesquisador 
(também como próprio participante) e os participantes da pesquisa teceu os procedimentos metodológicos abordados para a tessitura do trabalho, uma vez que Lescano vivencia e experiencia o contexto que pesquisa.

$\mathrm{Na}$ dissertação, o autor descreve como as vivências possibilitaram pensar os procedimentos metodológicos e trazer à baila as discussões que envolvem as crianças e seus modos de ser Guarani Kaiowá. A esse respeito, Lescano (2016, p. 81) aponta que "a enorme abrangência de tudo o que está associado à criança ou ao seu entorno forma o seu cenário cultural muito bem definido, com todos os elementos culturais, a partir da sua liberdade de transitar, do respeito por si mesmo e pelas regras postas para serem seguidas para ser um bom Guarani ou Kaiowá”.

A tese do professor Terena Antonio Carlos Seizer da Silva, intitulada de KALIVÔNO HIKÓ TERENÔE: Sendo criança indígena Terena do século XXI - vivendo e aprendendo nas tramas das tradições, traduções e negociações, buscou perceber, a partir das suas experiências como Terena, o processo de construção da criança indígena Terena antes da escolarização. A pesquisa foi desenvolvida na Terra Indígena Cachoeirinha (Miranda/ MS) e Terra Indígena Taunay/Ipegue (Aquidauana/MS), consideradas historicamente "terras indígenas-irmãs" (2016, p. 7). O autor destaca as estratégias metodológicas para o desenvolvimento da tese, defendida junto ao Programa de Pós-Graduação em Educação da Universidade Católica Dom Bosco - UCDB. Informa que esteve articulada à "pesquisa qualitativa - estudo de caso do tipo etnográfico (KLEIN; DAMICO, 2012), tendo como instrumento a análise bibliográfica, entrevistas com adultos de três gerações e observação participante com as crianças com registro no diário de campo". (2016, p.7)

Seizer da Silva (2016) permite a quem visita seus escritos conhecer as crianças Terena, seus atravessamentos, suas negociações e traduções com os discursos contemporâneos, bem como as ressignificações das crianças com os artefatos culturais que envolvem tanto a tradição Terena como aqueles artefatos que transitam nos espaços outros do seu povo. A esse respeito, encontramos nos escritos do autor questões que nos permitem perceber como as negociações transitam no contexto Terena, neste caso, no espaço da escola, 
pois "até os cinco anos em média, não criamos meninos, nem meninas, mas crianças, um universo de tudo para todos, sem categorização inicial, fato que começa a ocorrer quando vão para a escola, onde identificam seus pares de gênero (menino/menina) e com isso marcam o espaço e o seu entorno através das filas, dos brinquedos e brincadeiras, das vestimentas principalmente para as meninas" (p. 124). A escola no contexto Terena pesquisado funciona como um entre-lugares (criança Terena e marca de gênero na infância), como espaço de negociação dos próprios modos de ser da criança Terena.

Independente da cultura, "quando a criança se utiliza de um artefato em suas brincadeiras, ela personifica esse objeto a seu bel-prazer. Uma espiga de milho se torna uma boneca; um pedaço de pau, seu cavalo; as latas, carrinhos e/ou vagões de trens, tudo em sua mão se transforma, se ressignifica e isso não é apenas com objetos que aparentemente não tenham 'formas de brinquedos"' (p. 129).

Seizer da Silva (2016) narra a produção de identidades das crianças Terena e, nessa narrativa, discute as ressignificações, as tramas e traduções que permeiam essa produção identitária. O campo dos Estudos Culturais lhe serve como um procedimento analítico e político das relações culturais estabelecida na tríade criança Terena-modernidade-contemporaneidade.

Nesse campo teórico, o autor (2016, p. 168) relata que alguns apontamentos são possíveis para a compreensão do processo de construção da criança Terena, sendo que:

[...] antes da escolarização, principalmente, as negociações internas e externas; as 'modernas' e tradicionais; e ao mesmo tempo, mostrando que os fios as redes/ tramas por mais estreitos que sejam, são mais importantes que as formas geométricas formadas para/na rede, por maiores e bonitas que sejam, o que vale são os fios que teceram a trama e como a partir deles serão construídas novas tramas, construindo e desconstruindo sem o receio de tecer novamente, então, podemos dizer que esse processo é contínuo, étnico e intercultural.

Seizer da Silva (2016) discute o quanto é necessário perceber como os discursos que centram as crianças no contexto cultural, neste caso Terena, 
não são fixos e que há marcas que precisam ser observadas, entre elas a relação dos saberes indígenas com outros saberes. É essa relação, segundo o autor, que permite a construção da criança Terena na contemporaneidade.

Outra tese que discute as crianças indígenas (agora em contexto urbano) e se vale do campo teórico Estudos Culturais é o trabalho de Carlos Magno Naglis Vieira, vinculado também ao Programa de Pós-Graduação em Educação pela Universidade Católica Dom Bosco. Esse escrito, intitulado: A criança indígena no espaço escolar de Campo Grande/MS: identidades e diferenças, buscou "identificar os elementos que contribuem na produção de identidade e diferença das crianças indígenas em contexto urbano frente aos conflitos e às tensões produzidas na Escola Municipal Sulivam Silvestre Oliveira - Tumune Kalivono, no município de Campo Grande/MS"(VIEIRA, 2015, p.10). Como proposta metodológica, Vieira (2015) por meio da bricolagem, produziu seus dados utilizando entrevistas, observação participante, análise documental e bibliográfica e outros recursos, como desenhos, redações, fotografias e vídeos.

O trabalho de Vieira (2015, p.10) aponta que as identidades das crianças indígenas em contexto urbano são produzidas nos entrelugares, nas fronteiras do próprio espaço urbano e, especificamente, no âmbito da escola onde as identidades "sofrem com uma prática pedagógica de exclusão, silenciamento, subalternização e marginalização do diferente e, por isso, fazem do espaço escolar um 'entrelugar', constituindo estratégias próprias para garantir e afirmar o modo de ser indígena”.

Em uma das leituras realizadas nos escritos de Nascimento, em parceria com Urquiza e Vieira (2011, p. 34-35), falam da presença e das representações das crianças indígenas Kaiowá e Guarani. Vale a pena reescrever o trecho que segue para pensar essas ausências na presença: "as crianças estão presentes em todas as atividades do cotidiano, quando pequenas acompanham as mães a todos os lugares; quando crescidas, perambulam pelos espaços da aldeia, através das trilhas que levam às casas da parentela [...]”.

Considerando a especificidade do tema tratado, as crianças indígenas continuam a estar presente na vida de suas comunidades. As questões da liberdade por meio dos espaços sociais também dizem sobre as infâncias indígenas. 
Pereira (2011, p. 98), ao falar da participação das crianças Kaiowá e Guarani, em Mato Grosso do Sul, junto aos adultos, e como essa participação se dá por meio dos acompanhamentos que as crianças fazem, nos diz que:

Perceber a presença das crianças circulando entre os fogos exige que se reconheça sua importância para a vida política das comunidades. São atores políticos importantes e, no desempenho destes papéis, elas se socializam na prática política, no exercício de construção da identidade percebida como exclusiva ao fogo familiar ou à parentela. Paralelamente, também aprendem a lidar com os mercadores de alteridade que delineiam as fronteiras em relação aos outros módulos organizacionais. Em sua socialização a criança deve aprender a reconhecer e negociar com estes mercadores [...] Desde cedo estas crianças costumam acompanhar os pais em suas visitas a outras comunidades, ocasiões em que podem acompanhar eventos políticos e religiosos nos quais têm a oportunidade de observar as performances dos próprios parentes e líderes de outras parentelas.

Observa-se que, na sociedade indígena, as crianças têm direitos já alcançados em relação às crianças que compõem outras infâncias. Pensando em um contexto específico e pesquisados pelas autoras, citamos as crianças Arara-Karo do estado de Rondônia.

Diante dessas discussões sobre as infâncias, as crianças indígenas e posicionadas dentro do campo dos Estudos Culturais, não há nos sujeitos pesquisadores(as) a preocupação ou delimitação de trabalhar com elementos causais, técnicos, universais, mas podem pensar seu campo empírico a partir da provisoriedade dos acontecimentos, das narrativas das crianças, de suas concepções de mundo de criança, sua relação com o grupo, com o cotidiano e as inferências dessas situações diante da sua participação em relação aos seus grupos étnicos e com os outros.

As crianças indígenas Arara-Karo estão imersas no mundo das culturas que compõem seus espaços de vida. Que esses lugares de cultura estão na aldeia, nos espaços rurais que compõem a comunidade onde residem, assim como os espaços urbanos. Desse modo, as crianças indígenas fazem uso de diferentes artefatos culturais, carregados de significados, de 
representações, tais como: baton, maquiagem, celular, blusas com emblemas de cantores e cantoras de que gostam, jogos eletrônicos, entre outros, bem como os colares, as brincadeiras tradicionais e a própria ressignificação desses artefatos. Elas, por sua vez, fazem uso de outros artefatos culturais que produzem as suas identidades - criança-sujeito-indígena.

Se entendermos que a identidade não é algo fixo, absoluto, concreto, impossível de mudança, podemos prontamente negar que existe um estilo único de se apresentar como criança indígena. Existem diferentes culturas infantis indígenas (dentro da mesma comunidade, do mesmo grupo social). As crianças Arara-Karo transitam nesses espaços, nesses acontecimentos, são produzidas em meio a essas relações com seus pares, com os adultos indígenas e não indígenas e são constituídas em meio às diversas fronteiras que "habitam" os mesmos espaços.

Entendemos, pelas questões destacadas, que as representações produzidas por meio da pesquisa podem colaborar para a produção das identidades das crianças indígenas, e que essas identidades estão imbricadas na relação que temos e fazemos com o meio no qual estamos inseridos, uma vez que os olhares que atuam sobre elas não são neutros.

Desse modo, a representação que produzimos das crianças indígenas constitui suas identidades. No entanto, cada criança com sua particularidade, com sua multiplicidade de significados e representações, que dará a elas modos de ser específicos e coletivos, diferentes das demais crianças indígenas Arara-Karo, Guarani, Kaiová e Terena, citadas neste trabalho.

Ainda sobre os modos de ser das crianças indígenas Arara-Karo, elas são sujeitos atravessados por marcas culturais indígenas e não indígenas, e continuam sendo crianças, estudantes, filhos, consumidores e têm medos e sonhos. Todas essas representações culturais produzem suas identidades; as crianças indígenas são sujeitos de identidades plurais.

Seus modos se constituem na maneira como experienciam o mundo e em como vivem esse mundo. A "infância indígena” nas aldeias, por exemplo, se diferencia muito dos modos como as crianças urbanas funcionam no cotidiano de suas vidas. Dificilmente, nas aldeias indígenas, (como das crianças Arara-Karo do Município de Ji-Paraná-Rondônia), as crianças são 
encontradas ao redor dos adultos, com estes as controlando, no sentido de "não sobe aí que você vai se machucar, não faz isso ou aquilo". As crianças indígenas estão no mundo, e Nunes (2002) nos ajuda a pensar sobre isso quando relata:

Em nome da tranquilidade da ordem social, da educação que a preparará para entrar no mundo adulto, da insegurança doméstica ou urbana, a criança das sociedades urbanas acaba por ser isolada em espaços e tempos definidos pelos adultos como os mais adequados para suas várias idades. A cidade, a escola e a própria casa são contextos cheios de regras ou sofisticados esquemas que constrangem a relação das crianças com o que está para além dessas fronteiras. Nas sociedades indígenas brasileiras, de acordo com os relatos e trabalhos disponíveis, a fase que corresponde à infância é marcada pelo que consideramos ser uma enorme liberdade na vivência do tempo e do espaço, e das relações societárias que por meio destes se estabelecem, antecedendo ao período de transição para a idade adulta que, então, inaugura limites e constrangimentos muitos precisos (p. 65).

Trata-se de mostrar como circulam, transitam, ressignificam esses espaços, as relações estabelecidas nele e com ele. Todos esses acontecimentos, essas experiências cotidianas produzem as crianças, seu modo de perceber o mundo e de estar nele.

A partir dessas conceitualizações sobre a infância e a criança contemporânea e buscando articular com os Estudos Culturais, podemos ir problematizando que o sujeito é construído no interior das representações culturais. Ao pensar a centralidade da cultura (HALL, 1997) como um atravessamento das práticas políticas, culturais, econômicas e sociais, e no processo de ressignificação da cultura, logo o sujeito se ressignifica. Nesse sentido, se hibridizam as práticas e os sujeitos.

Como trazer à tona as vozes das crianças no contexto da pesquisa e, a partir de suas narrativas, seus olhares, suas percepções, torná-las visíveis na transcrição, análise e produção dos dados? Talvez pensando na provisoriedade das respostas, das análises, da escrita, da interpretação, da participação, do contexto, da representação das crianças em meio às respostas, ao observado, 
ao visto, participado, tocado em meio ao contexto, aos sujeitos (crianças, adultos, mais velhos, pesquisadora) e ao que se pergunta. Levando em consideração também as experiências, vivências, aquilo que marcou, deixou vestígio (LARROSA, 2011) durante todo processo de pesquisa.

Vale ressaltar, segundo Damico e Klein (2012), que não há neutralidade na pesquisa, pois nos colocamos, nos retiramos (quando convenientes) tanto no processo de produção de dados, quanto na análise que fazemos com e dos referidos dados produzidos. Na perspectiva dos Estudos Culturais, a ausência da neutralidade mostra-se no próprio texto e na referência do posicionamento que nós, enquanto autores(as) da escrita do trabalho, tomamos em relação à pesquisa e aos sujeitos. No entanto, é necessário estar atento às várias táticas para a produção dos dados.

As pesquisas devem provocar uma reflexão de como as coisas (identidades, relações, contexto, tempo, espaço, práticas) são produzidas. A pesquisa não tem, a priori, um projeto propositivo de ação, de mudança, mas são as reflexões provocadas, as discussões apresentadas na pesquisa que possibilitam práticas reflexivas que nos permitem problematizar, ressignificar, subverter, dialogar, articular, hibridizar os sujeitos e seus contextos.

Há, em curso, uma dilatação da produção de conhecimentos que se vale do campo dos Estudos Culturais (NELSON et al. , 2012; COSTA, 2004). Autores de vários campos e interesses têm visto nos Estudos Culturais não apenas uma forma de descentralizar as essencialidades das disciplinas clássicas, mas de por em funcionamento um conjunto amplo de métodos e técnicas que servem para ampliar a linhas de alcance de suas pesquisas. Reconhecidamente, existe uma forma desencaixada de produção de conhecimento inaugurado pelo campo dos Estudos Culturais que, ao subverter a relação entre sujeito - objeto, não apenas mostra a artificialidade desse processo, como também assinala que essa forma clássica de produzir conhecimento é uma montagem histórica e cultural.

Argumentos instituídos por Nelson et al. (2012) sugerem que [...] "de fato, os Estudos Culturais não são simplesmente interdisciplinares, como outros tem dito, ativo e progressivamente antidisciplinar" (NELSON et al., 
2012, p. 8). Essa forma deslocada e cambiante de produzir conhecimentos não significa, por sua vez, a construção de elementos conceituais descompromissados com a textualidade histórica do poder e suas várias engenharias culturais. Todas as estratégias de pesquisas nesse campo são instituídas de forma a mostrar o papel operante da cultura na constituição de sistemas complexos de representação que articulam elementos "pré-fixados" pela tradição aos conceitos disponibilizados pelas relações de natureza intercultural.

O campo sugere que o pesquisador seja um alquimista do saber e, para isso, passa a experimentar e empregar metodologias em versões "puras" ou hibridizadas. Os Estudos Culturais mostram o compromisso político e teórico de toda a produção do conhecimento ao não pressupor a criação hipotética de pesquisa, haja vista que "[...] A escolha de práticas de pesquisas depende das questões que são feitas e as questões dependem de seu contexto" (NELSON et al., 2012, p. 10). Tais enunciações assinalam que não há hipóteses a serem provadas no conjunto das pesquisas que se valem deste campo, mas a canalização de instrumentos de pesquisas e produção de dados que servem para descrever as engrenagens da maquinaria social, vista como uma produção humana e nada mais.

Os Estudos Culturais, como campo inter/trans/in/disciplinar, reconhecem e mostram "[...] as sociedades capitalistas industriais como lugares de divisões desiguais no que se refere a etnia, sexo, divisões de gerações e de classe. A cultura é um dos principais lócus onde são estabelecidas e contestadas tais divisões, onde se dá a luta pela significação" [...] (COSTA, 2004, p. 25). Oportunamente, os Estudos Culturais se instituem como teorias de fronteiras e, além delas, cruzam por todos os lados e direções, sem, contudo, perder a centralidade da cultura no processo de transformação da sociedade.

Para finalizar, temporariamente, trazemos um excerto de Larrosa que, nesse momento, reflete nosso posicionamento sobre os estudos, as pesquisas, as leituras, as escritas que temos feito sobre as crianças indígenas: "[...] as crianças, esses estranhos dos quais nada se sabe, esses seres selvagens que não entendem nossa língua". E segue indicando que: "a infância como um outro não é o objeto (ou objetivo) do saber, mas é algo que escapa a qualquer objetivação e que se desvia de qualquer objetivo.” (2003, p. 185) 


\section{Referências}

AQUINO, Alda Vasques de. Educação escolar indígena e os processos próprios de Aprendizagem: espaço de inter-relação de conhecimentos na infância Guarani/Kaiowá, antes da escola, na Comunidade Indígena de Amambai - Amambai-MS. Campo Grande, 2012. 118p. Dissertação de Mestrado em Educação - Universidade Católica Dom Bosco/ UCDB, 2012.

BACKES, José Licínio; NASCIMENTO, Adir Casaro. Aprender a ouvir as vozes dos que vivem nas fronteiras étnico-culturais e da exclusão: um exercício cotidiano e decolonial. Séries-Estudos, Campo Grande, n. 31, p.25-34, jan./jun., 2011.

BARBERO, Jesús Martín. Os exercícios de ver. 2. ed. São Paulo: SENAC, 2004.

BENJAMIN, Walter. Reflexões sobre o brinquedo, a criança e a educação. São Paulo, Ed. 34, 2002.

BHABHA, Homi K. O local da cultura. Belo Horizonte: Ed. UFMG, 1998.

BHABHA, Homi K. O terceiro espaço: uma entrevista com Homi Bhabha. Revista do Patrimônio Histórico e Artístico Nacional, n.24, p. 35 - 41, 1990. Entrevista realizada por Jonathan Rutherford.

COSTA, Marisa Vorraber. Estudos Culturais: para além das fronteiras disciplinares. In: COSTA, Marisa Vorraber (Org.). Estudos Culturais em Educação: mídia, arquitetura, brinquedo, biologia, literatura, cinema. Porto Alegre: UFRGS, 2015.

FARIAS, Edineide Bernardo. A criança indígena Terena da aldeia Buriti, em Mato Grosso do Sul: O primeiro contato escolar. 2014. 91p. Dissertação de Mestrado em Educação. Universidade Católica Dom Bosco (UCDB).Campo Grande, 2014.

HALL, Stuart. Da diáspora: identidades e mediações culturais. 1. ed. Belo Horizonte: Editora UFMG, 2011.

HALL, Stuart. A Identidade Cultural na Pós-modernidade. 10. ed. Tradução de Tomaz Tadeu da Silva. Rio de Janeiro: DP\&A, 2005.

KLEIN, Carin; DAMICO, José. O uso da etnografia pós-moderna para a investigação de políticas públicas de inclusão social. In: MEYER, Dagmar Estermann. PARAÍSO, Marlucy Alves Paraíso. Metodologias de pesquisa pós-críticas em educação. Belo Horizonte: Mazza Edições, 2012.

KIRCHOF, Edgar Roberto; WOETMANN, Maria Lúcia; COSTA, Marisa Vorraber. Apontamentos à guisa de introdução. In: KIRCHOF, Edgar Roberto; WOETMANN, Maria Lúcia; COSTA, Marisa Vorraber (Orgs). Estudos Culturais e Educação: contingências, articulações, aventuras, dispersões. Canoas: Ed. Ulbra, 2015. 
LARROSA, Jorge. Tecnologias do eu e educação. In: SILVA, Tomaz Tadeu da. (Org.) O sujeito da educação: estudos foucaultianos. 12. ed. Petrópolis, RJ: Vozes, 2011.

LARROSA, Jorge. Pedagogia profana: danças, piruetas e mascaradas. 4. ed. Belo Horizonte: Autêntica, 2003.

LESCANO, Claudemiro Pereira. Tavyterã reko rokyta: os pilares daeducação guarani kaiowá nos processosprópriosde ensino e aprendizagem. 2016. 109p. Dissertação de Mestrado. Universidade Católica Dom Bosco, 2016.

NASCIMENTO. A. C; URQUIZA, A. H. A.; VIEIRA, C. M. N. A cosmovisão e as representações das crianças Kaiowá e Guarani: o antes e o depois da escolarização. In: NASCIMENTO. A. C. (Org.). Criança indígena: diversidade cultural, educação e representações sociais. Brasília: Liber Livro, 2011.

NELSON, Cary; TRECHLER, Paula A.; GROSSBERG, Lawrence. Estudos Culturais: uma introdução. In: SILVA, Tomaz Tadeu da (Org.). Alienígenas na Sala de Aula: uma introdução aos Estudos Culturais em Educação. Petrópolis: Vozes, 2012.

NUNES, Angela. No tempo e no espaço: brincadeiras das crianças A 'uwe-Xavante. In: Silva, Aracy; Macedo, Ana Vera; Nunes, Angela. Crianças indígenas: ensaios antropológicos. São Paulo: Global, 2002.

PEREIRA, Levi Marques. A socialização da criança Kaiowá e Guarani: formas de sociabilidade internas às comunidades e transformações históricas recentes no ambiente de vida. In: NASCIMENTO, Adir Casaro et al (Orgs). Criança indígena: diversidade cultural, educação e representações sociais. Brasília: Líder Livro, 2011.

VIEIRA, Carlos Magno Naglis. A criança indígena no espaço escolar de Campo Grande/ MS: identidades e diferenças. Campo Grande, 2015. 228 p. Tese de Doutorado em Educação - Universidade Católica Dom Bosco/UCDB.

SEIZER DA SILVA, Antonio Carlos. Kalivôno Hikó Terenôe: Sendo criança indígena Terena do século XXI - vivendo e aprendendo nas tramas das tradições, traduções e negociações. Campo Grande, 2016.189p. Tese (Doutorado em Educação) Universidade Católica Dom Bosco/UCDB.

WOODWARD, Kathryn. Identidade e diferença: uma questão conceitual. In: SILVA, Tomaz T. (Org.). Identidade e diferença. A perspectiva dos Estudos Culturais. Petrópolis; Vozes, 2012. 


\title{
4. INDÍGENAS NA EDUCAÇÃO SUPERIOR EM RONDÔNIA
}

\author{
Regina Aparecida Costa (PPGE/UNIR) \\ José Lucas Pedreira Bueno (PPGEEProf/UNIR) \\ Juracy Machado Pacífico (PPGEEProf/UNIR)
}

\section{Introdução}

Quais as vias de acesso e quais fatores favorecem o indígena a ingressar no ensino superior? Foram essas as questões que motivaram a elaboração deste estudo. Os dados apresentados representam um recorte temporal, ou seja, matrículas de indígenas na educação superior em Rondônia no ano de 2011.

Consideramos importante fazer uma abordagem sobre o que falamos quando falamos em educação. Isso devido ao entendimento de que o conceito e a definição para educação são manifestados de várias formas, mas com pontos em comum. A educação pode ser restrita a um período ou pode estar relacionada com a cultura de uma sociedade. Além disso, pode ser representada por sistema de leis estruturantes, a exemplo da LDB n ${ }^{\circ}$ 9394/96 e outras diretrizes, ou a partir de abordagens filosóficas. Partimos, portanto, dessas manifestações para delimitar nosso entendimento.

Assim, ao pesquisar sobre educação, vemos que as definições e fundamentos repousam sobre um conjunto de abordagens e dimensões, disciplinas e áreas que possibilitam ou resultam na formação de um sistema cultural de um determinado povo (FREIRE, 2005). A educação representa também a possibilidade de construção de um processo de conhecimento capaz de promover mudanças, visto que seu mecanismo dinâmico se articula com os demais sistemas sociais, tais como a economia, a política e a religião. Sendo assim, os sistemas educacionais têm como referência um conjunto de valores e tradições determinantes para a formação da identidade de um 
povo (FREIRE, 2005), razão pela qual não há neutralidade nem fora e nem dentro dos sistemas.

Na obra Educação como prática da liberdade (2011), do educador Paulo Freire, a educação representa "um ato de amor e, por isso, um ato de coragem”. Nesse sentido, o autor aponta a questão da conscientização, a liberdade de expressão e a necessidade de autonomia. Somente a educação é capaz de enfrentar as mais diferentes batalhas para assegurar os direitos e a liberdade de uma nação. A educação leva ao debate. Nessa obra estão relatadas as diferentes concepções de ser humano em relação ao mundo e seu desenvolvimento, possibilitados pela educação. Nesse sentido, Paulo Freire ressalta a importância da participação do ser humano, homens e mulheres, nos rumos da nação. Para Freire, é necessário que façamos uma "educação corajosa", capaz de levar o ser humano comum à discussão de seus direitos (FREIRE, 2011, p. 122).

No aporte de Paulo Freire, a educação também é um ato político. Se não, como entender as palavras proferidas na abertura de uma seção do livro Pedagogia do Oprimido (2005, p.23): "Aos esfarrapados do mundo e aos que neles se descobrem e, assim descobrindo-se, com eles sofrem, mas, sobretudo com eles lutam"? Trata-se de um ideal claro de luta de classes, aqui situados como oprimidos em confronto com os opressores. Observa-se o quão intenso e atual é o trecho citado, pois não se tem observado outra coisa a não ser uma interminável luta de classes. Com essas palavras, o autor situa o ser humano sempre em busca da liberdade, sujeito de si e não como mero objeto ou mero expectador (FREIRE, 2005, p. 23).

Em consonância com o discurso de Paulo Freire, se situa a questão da educação escolar indígena, em todos os níveis, que desde a invasão portuguesa sofreu interferências externas e se obrigou à adaptação aos moldes tradicionais de educação praticados pelos europeus (RIBEIRO, 2005). Os indígenas têm uma visão diferente de educação em relação à cultura de não indígenas. Enquanto a educação tradicional acontece no espaço escolar adequado, a educação, para os indígenas, acontece em todo ambiente, não necessariamente a escola. Todo o sistema é compreendido como um aprendizado. A responsabilidade de educar é de todos (LUCIANO, 2006). Têm-se 
observado avanços nessa direção, conforme a publicação da Unesco (2006), e situada por Luciano, para quem a educação indígena está definida como

Os processos próprios de transmissão e produção dos conhecimentos dos povos indígenas, enquanto a educação escolar indígena diz respeito aos processos de transmissão e produção dos conhecimentos não indígenas e indígenas por meio da escola, que é uma instituição própria dos povos colonizadores (LUCIANO, 2006, p. 129).

$\mathrm{O}$ autor acrescenta que, durante muito tempo, os indígenas conviveram com a ideia de que a educação escolar era um processo de aculturação, portanto havia certa "desconfiança", conforme relata o autor, em relação ao processo de escolarização. Mas esse posicionamento tem sinalizado mudanças, visto que o indígena também já vislumbrou o processo de globalização que impactou a sociedade como um todo. Diante disso, a educação superior acena como um caminho em direção ao atendimento de necessidades e um "instrumento de fortalecimento das culturas e das identidades indígenas e um possível canal de conquista da desejada cidadania, entendida como um direito de acessos aos bens e aos valores materiais e imateriais do mundo moderno" (LUCIANO, 2006, p. 129).

No que tange à educação superior indígena, a sociedade atual vivencia debates ressaltando sua importância, por entender que o acesso a ela se constitui em uma força na construção do conhecimento, além de avanços em pesquisas e inovações, que se apresentam como melhorias para as sociedades indígenas. Convém ressaltar que nesse sentido o conhecimento construído na universidade pode retornar em projetos e aprendizagens sob a orientação de indígenas que podem compartilhar com as suas comunidades (UNESCO, 2009).

Neste estudo, analisa-se a presença de indígenas na educação superior em Rondônia e foi desenvolvido a partir de levantamento bibliográfico e pesquisa documental. $\mathrm{Na}$ pesquisa documental, analisou-se o projeto pedagógico do curso de licenciatura em Educação Básica Intercultural, ofertado pela Fundação Universidade Federal de Rondônia, campus de Ji-Paraná. Também foi realizada entrevista com a coordenação do curso. 
Portanto, será apresentado uma visão parcial da presença de indígenas na educação superior em Rondônia, o que implicará em descrição pormenorizada do curso de licenciatura em educação básica intercultural, ofertado pela Unir, Campus de Ji-Paraná, que representou uma importante via de acesso a indígenas na educação superior em Rondônia.

\section{A educação superior e o acesso a indígenas}

O acesso à educação superior no Brasil está longe de ser democratizado, mesmo considerando que os programas de expansão tenham possibilitado aumento significativo de matrículas nesse nível nos últimos anos. Esse aumento de matrículas pode ser observado em documento intitulado Mapa do Ensino Superior no Brasil, publicado em 2015, pelo Sindicato das Mantenedoras de Ensino Superior (SEMESP, 2015). De acordo com os dados,

Nos últimos 13 anos, o número de matrículas em cursos presenciais das IES públicas e privadas no Brasil cresceu 129\%, sendo que em 2013, período mais recente do levantamento, o aumento chegou a 3,8\%. No ensino a distância (EAD), de 2009 a 2013, o crescimento ficou em $37,5 \%$, refletindo um crescimento de $50 \%$ na rede privada e uma queda de 10,5\% na rede pública. Em 2013, enquanto o crescimento do EAD na rede privada alcançou 7,2\%, na rede pública a queda chegou a 14,9\%. Com relação aos cursos tecnológicos de nível superior, de 2009 a 2013, as matrículas tiveram um aumento de $26,4 \%$, sendo que, em 2013, o crescimento ficou em 2,2\% (1,2\% na rede privada e 6,2\% na pública). (SEMESP, 2015, p. 5).

Identifica-se outro dado importante quando se analisa o acesso por região. De acordo com o documento, "A Região Sudeste é responsável por $47,2 \%$ de matrículas em cursos presenciais no ensino superior no Brasil, seguida pelas regiões Nordeste (20,9\%), Sul (15,6\%), Centro-Oeste (9,4\%) e Norte (6,9\%).” (SEMESP, 2015, p. 8). Ou seja, a região Norte é a que tem o menor quantitativo de ingressos na educação superior, mas isso precisa ser relativizado, considerando-se que também é a região Norte que, comparada às demais, possui a menor população, o que equivale a 8,5\% da 
população do Brasil. A região Sudeste, sozinha, é responsável por 41,9\% da população do país.

Por outro lado, se o acesso à educação superior não atinge parcela significativa da população, como será, então, o acesso dos povos indígenas à educação superior em Rondônia? De acordo com texto publicado por Neves $(2012)^{1}$, organizadora desta obra, percebe-se que, se os povos indígenas não estão na universidade pública, isso não se deve à ausência de indígenas na região. Segundo a professora,

O Estado de Rondônia possui uma das mais significativas populações indígenas do país - cerca de 11 mil pessoas, distribuídas em 23 Terras Indígenas que representam um total de $20,82 \%$ da área do estado (GTA, 2008), abrigando etnias como os Arara, Gavião, Cinta-Larga, Suruí, Karitiana, Karipuna, Tupari, sabanê, aikanã, Makurap, Kaxarari, Oro Nao', Oro Win, Oro Mon, Oro Eo, Oro Waran, Oro Waran Xijein, Oro Cao Waje, Djeromitxi, Canoé, Salamãi, dentre outros povos, além dos grupos urbanos, como os Cassupá, os ressurgidos como os Puruborá e os indígenas livres ou isolados.

Bergamaschi e Kurroschi (2013) destacam que, no Brasil, o acesso de indígenas aos cursos de graduação iniciou timidamente, mas o saldo dos últimos anos pode ser considerado positivo, pois,

[...] na última década registra-se um aumento substancial do acesso indígena ao ensino superior [...] há dez anos havia 1.300 universitários indígenas, majoritariamente em instituições privadas, com apoio da FUNAI, ou de instituições estrangeiras; em 2013 estimam-se quase dez mil, predominantemente em Universidades Públicas.

Observa-se nesse crescimento o impacto das ações governamentais, mas, principalmente, dos movimentos dos povos originários que, entre outros caminhos, elegeram também o ensino superior como um espaço de afirmação e as universidades como aliadas em suas lutas. (BERGAMASCHI; KURROSCHI, 2013, p. 3-4).

\footnotetext{
$\overline{1}$ Texto publicado no site http://www.tudorondonia.com.br/, disponível em: <http://www. tudorondonia.com.br/noticias/a-unir-e-os-povos-indigenas-de-rondonia-a-invisibilidade-do-tema-nas-pautas-dos-reitoraveis-na-eleicao-2012-,26907.shtml>. Publicado em: 27 fev.2012. Acesso em: abr. 2015.
} 
Ainda de acordo com Bergamaschi e Kurroschi (2013), no Brasil, mais de 70 universidades públicas, além das vagas ofertadas em cursos de licenciaturas interculturais, garantem o direito de ingresso a indígenas na educação superior, a partir de três possibilidades:

1) reserva de vagas, com um número específico ou um percentual em relação às vagas universais oferecidas em cada ingresso; 2) bônus no processo seletivo, modalidade em que o candidato recebe pontos para concorrer no processo seletivo regular, imaginando-se com isso igualá-lo ao patamar dos demais candidatos; 3) vagas suplementares, em geral um número específico em cursos determinado pela universidade e ou pelas comunidades indígenas, ou em conjunto. Para esta modalidade há um processo seletivo diferenciado. (BERGAMASCHI; KURROSCHI, 2013, p. 7).

Considerando os dados apresentados, é possível confirmar que há a possibilidade de ingresso de indígenas em cursos superiores, de licenciaturas ou bacharelados, nas universidades públicas e privadas do Brasil. Mas, e em Rondônia, Estado da região Norte do Brasil, onde o acesso à educação superior de modo geral ainda representa um mínimo e está aquém das demais regiões do Brasil?

\section{Indígenas de Rondônia na educação superior e curso de Licenciatura em Educação Básica Intercultural da UNIR}

O número de indígenas inseridos na educação superior em Rondônia é concernente, em sua maioria, ao curso de licenciatura em educação básica intercultural, ofertado pela Universidade Federal de Rondônia, no campus de Ji-Paraná. Além disso, as IES particulares também apresentam alguns números de indígenas matriculados, onde se obtiveram dados mediante a aplicação de instrumento de coleta, com a secretaria geral de cursos e gerência acadêmica, além de contatos telefônicos com a representação estadual de ensino e com a Funai, nas representações administrativas de Cacoal e Guajará-Mirim. (COSTA, 2012).

$\mathrm{Na}$ capital, Porto Velho, Ferreira (2011) apresentou um levantamento realizado junto a quatro IES, onde se obtiveram os seguintes resultados: havia 
14 indígenas presentes na educação superior, distribuídos em oito cursos. Desse total, 11 alunos são beneficiários de bolsa integral do Prouni; dois alunos não possuem nenhum tipo de auxílio com bolsa de estudo e um aluno tem 30\% de bolsa, não identificada a origem desse auxílio. Nota-se, portanto, a prevalência do Prouni, como uma fonte de acesso recorrida por esses universitários.

O Quadro 1 ilustra a presença de indígenas na educação superior, de etnias que têm sua representação administrativa nas cidades de Porto Velho, Cacoal e no Estado do Acre.

Quadro 1 - Presença de indígenas na educação superior em Porto Velho RO - 2011

\begin{tabular}{|c|c|c|c|c|}
\hline Etnia & Curso & Faculdade & Bolsa & $\begin{array}{c}\text { Administração } \\
\text { (FUNAI) }\end{array}$ \\
\hline Suruí & Administração & São Lucas & Prouni & Cacoal \\
\hline Suruí & Biologia & São Lucas & Prouni & Cacoal \\
\hline Suruí & Turismo & São Lucas & Prouni & Cacoal \\
\hline Suruí & Direito & FARO & Prouni & Cacoal \\
\hline Suruí & Administração & São Lucas & Prouni & Cacoal \\
\hline Kaxinawá & Enfermagem & FARO & Prouni & Acre \\
\hline Cassupá & Farmácia & FIMCA & Prouni & Porto Velho \\
\hline Cassupá & Enfermagem & São Lucas & Prouni & Porto Velho \\
\hline Cassupá & Ed.Física & FIMCA & Sem bolsa & Porto Velho \\
\hline Cassupá & Administração & FIMCA & Sem bolsa & Porto Velho \\
\hline Karitiana & Enga Florestal & FARO & Prouni & Porto Velho \\
\hline Karitiana & Enfermagem & FARO & Prouni & Porto Velho \\
\hline Karitiana & Administração & FARO & Prouni & Porto Velho \\
\hline Paritintin & Ed.Física & ULBRA & $30 \%$ de bolsa & Porto Velho \\
\hline
\end{tabular}

Fonte: Ferreira $(2011)^{2}$

O Estado de Rondônia tem pela frente o desafio que se inicia pela dificuldade de se coletar informações precisas sobre o acesso e permanência dos povos indígenas no espaço universitário. As informações se limitam

\footnotetext{
${ }^{2}$ FERREIRA, Leidiane da Silva. A inserção do Indígena no Ensino Superior em Porto

Velho - RO. Disponível em http://www.webartigos.com. Acesso em 20 maio 2011.
} 
às publicações de pesquisas em sites da Funai e institutos ligados ao meio ambiente, como é o caso do Instituto Socioambiental. A questão territorial também deve ser considerada, em função de alguns povos estarem isolados e com o acesso restrito (LUCIANO, 2006).

Observamos que os programas de formação de professores representaram, até 2012, a forma mais efetiva de acesso de indígenas na educação superior. Conforme Venere (2011), em Rondônia, a educação escolar e a formação de professores indígenas ganharam visibilidade mediante o "I Encontro de Professores Indígenas do Estado de Rondônia”, realizado na cidade de Vilhena, em 1990. A partir dessa data, segundo o autor, o governo do Estado reconhece os "professores indígenas como integrantes da Categoria profissional de docentes, deixam de ser 'meros monitores' bilíngues" (VENERE, 2011, p. 26).

A formação de professores para o magistério indígena, segundo Venere (2011), foi iniciada por intermédio de projetos pedagógicos de responsabilidade do Estado e dos municípios, em virtude da transferência da responsabilidade pela educação indígena, antes da Funai, atualmente, pelo MEC. Este, por sua vez, transferiu para Estados e municípios o desenvolvimento e execução de propostas que atendessem aos dispositivos legais previstos no decreto 26/91, artigos $1^{\circ}$ e $2^{\circ}$. Ainda segundo o autor, uma série de ações se desenvolve no Estado de Rondônia em torno da política de educação escolar e a formação de professores indígenas, com várias frentes de representação, com o propósito de construção de um projeto pedagógico que atenderia às comunidades indígenas em suas especificidades. Dentro de um conjunto de propostas surgiu o "Projeto Açấ", elaborado para o atendimento das séries iniciais do ensino fundamental em escolas situadas em terras indígenas ${ }^{3}$. Acrescenta que,

[...] devido aos apelos das lideranças e movimentos indígenas, discutiu-se a necessidade de formação de professores indígenas para atender às peculiaridades de cada povo. As discussões resultaram na criação do

\footnotetext{
${ }^{3}$ Projeto Açaí - Curso de Formação de Professores para o Magistério Indígena. In: VENERE, 2011, p. 31.
} 
referido projeto, cabendo à SEDUC-RO, com a participação de representantes das comunidades, elaborarem as linhas básicas do projeto, sua estrutura, o projeto pedagógico e sua gestão. Toda a estrutura do Projeto foi discutida com as representações das comunidades indígenas de Rondônia, resultando em um projeto básico elaborado pela SEDUC. Uma das discussões que tomou tempo significativo foi com relação à carga horária, pois era preciso estabelecer alguns critérios que estivessem de acordo com as disponibilidades dos professores indígenas, mas que atendessem aos critérios legais e normativos da legislação educacional brasileira (VENERE, 2011, p. 82).

A primeira oferta do projeto foi executada no período de 1998 a 2004, com a formação de 120 professores; e foram esses professores que fizeram parte da demanda para a construção do curso de licenciatura em educação básica intercultural, aprovado em 2009 pela Unir, para ser ofertado no campus de Ji-Paraná.

O curso de Licenciatura em Educação Básica Intercultural está implantado na Universidade Federal de Rondônia, no campus de Ji- $\mathrm{Pa}-$ raná. A universidade tornou pública a abertura do curso de licenciatura em educação básica intercultural com o primeiro vestibular realizado no ano de 2009, com a publicação do edital de no 009, de 11 de agosto de 2009, com oferta a partir do segundo semestre do mesmo ano. A oferta foi de 50 vagas para professoras e professores indígenas, oriundos do projeto Açai. ${ }^{4}$

De acordo com informações contidas no Edital, o curso foi ofertado em regime de turno integral. No ano seguinte, a Universidade Federal publicou o edital no 021 , de 23 de julho de 2010, com a oferta de mais 50 vagas para professoras e professores indígenas, sendo mantida a oferta nos próximos anos. O projeto considerou, para sua elaboração e execução, os seguintes instrumentos legais: a Constituição Federal de 1988; a LDB

\footnotetext{
${ }_{4}^{4}$ Programa de Formação de Professores Indígenas, denominado projeto Açaí. Esta formação ocorreu entre os anos de 1998 e 2004, dividida em 11 etapas, sendo que uma destas realizou-se nas comunidades - "Açaí nas Aldeias". Este projeto habilitou aproximadamente 120 professores em Magistério Indígena para atuarem com alunos de $1^{\mathrm{a}}$ a $4^{\mathrm{a}}$ série do ensino fundamental. (UNIR - PPC, 2008, p. 5). A segunda etapa esteve em vigência desde o ano de 2009 e se encerrou em 2013.
} 
9394/96; o Plano Nacional de Educação de no 10.172/2001; Pareceres e Resoluções decorrentes.

O curso de licenciatura em educação básica intercultural está voltado para a formação de professor(a) multidisciplinar para o ensino fundamental e professor(a) para atuar no ensino médio. $O$ curso abrange as seguintes áreas de formação do futuro profissional: 1. Educação escolar intercultural no ensino fundamental e gestão escolar; 2 . Ciências da linguagem intercultural; 3. Ciências da natureza e da matemática intercultural; e 4. Ciências da sociedade intercultural. Além dessa estrutura curricular, o curso se compõe ainda de atividades de prática de ensino e estágio supervisionado, totalizando 4.200 horas, assim distribuídas: 2.500 horas para a formação básica; 1.700 horas para a formação específica e 400 horas para a prática de ensino.

No histórico de construção do projeto pedagógico do curso de licenciatura em educação básica intercultural no campus da Universidade Federal de Rondônia, localizado no município de Ji-Paraná, consta como propósito a ampliação do programa de formação de professores indígenas iniciado com o projeto Açaí, considerado um marco de realização da educação escolar indígena executado pela SEDUC.

Sobre esse projeto, tem-se a seguinte consideração:

Em 2004 os professores concluíram o Açaí e apenas em 2007 receberam a certificação oficial. Durante esses anos as discussões sobre a continuidade da formação destes professores já era tema de seminários e mesas redondas. Configura-se, então, um momento de luta por um espaço dentro da Universidade para um curso específico, destinado a professores indígenas, numa perspectiva intercultural (UNIR - PPC, 2008, p. 17-18).

Dessa forma, conforme consta do projeto original do curso de licenciatura em educação básica intercultural, os professores indígenas reivindicavam a continuação de seus estudos. Cria-se nesse momento uma demanda legítima para a construção de um projeto pedagógico que contemple esses professores que queriam ampliar o campo de conhecimento.

Para a consolidação da proposta apresentada, o curso tem como objetivo geral formar e habilitar professores indígenas em licenciatura 
intercultural para lecionar nas escolas de ensino fundamental e médio e atender às comunidades indígenas.

A justificativa para a abertura do curso de licenciatura em educação básica intercultural está assim descrita no projeto pedagógico:

Justifica-se a criação do curso: Como uma proposta do Departamento de Ciências Humanas e Sociais do Campus de Ji-Paraná, por compreender que uma sociedade que se pretende justa e cidadã deve considerar necessariamente a inclusão dos povos indígenas, e isto subverte o acesso ao ensino superior. O Perfil do Egresso: Propõe competência para exercer as funções de Magistério nas Escolas de Ensino Fundamental e Médio, bem como, a depender da Formação Específica escolhida, exercer cargos de gestão no âmbito da educação (UNIR - PPC, 2008, p. 22).

A proposta de implantação do projeto atende a convocação do Ministério da Educação e Cultura - MEC, que articula políticas educacionais voltadas para a graduação e pós-graduação.

Para cumprir as diretrizes estabelecidas pelo MEC, as universidades têm que atender aos dispositivos publicados em Edital e aprovados pela Comissão Especial, criada pela portaria no 52, de 29 de outubro de 2004, para elaborar políticas de educação superior indígena - CESI/SESU/ MEC, seguindo, ainda, as normas descritas na lei $n^{\circ} 11.514$, de 13 de agosto de 2007, o decreto $n^{\circ} 6170$, de 2007, a portaria interministerial $n^{\circ} 127$, de 2008 e as demais normas que regulam o programa.

As propostas descritas e o texto na íntegra constam do processo 23118.001886/2008-52, que discute também a adesão da Unir às determinações do sistema de planos de Reestruturação e Expansão das Universidades Federais (REUNI); do Programa de Formação Superior e Licenciaturas Indígenas (PROLIND) e da Secretaria de Ação Continuada, Alfabetização e Diversidade (SECAD). ${ }^{5}$

\footnotetext{
${ }^{5}$ Consta, no plano de providências Reuni, item E. do Compromisso Social da Instituição e no item E.1. Políticas de Inclusão, que a universidade pretende executar, entre seus planos de metas a serem alcançadas, a criação do curso de licenciatura intercultural em educação básica para professores indígenas.
} 
Também consta no histórico de construção do projeto pedagógico do curso de licenciatura em educação básica intercultural a ampliação do programa de formação de professores indígenas iniciado com o projeto Açaí, considerado um marco de realização da educação escolar indígena executado pela Seduc, no ano de 1998 e que habilitou 120 profissionais índios para atuarem nas séries iniciais. Embora a primeira fase desse projeto tenha sido encerrada no ano de 2004, no ano de 2006 é que os professores indígenas foram legalmente habilitados.

No projeto consta ainda que seriam abertas para cada processo seletivo 40 vagas anuais, visto que, conforme descrição, o espaço físico das salas de aula comportava esse número de alunos, para que o trabalho fosse executado de forma confortável e satisfatória, do ponto de vista pedagógico. O colegiado de curso, de acordo com o projeto, está vinculado ao departamento de Ciências Humanas e Sociais da Unir - Campus de Ji-Paraná.

Para a efetivação da proposta pedagógica e o cumprimento da matriz curricular seria necessária, de acordo com a descrição do PPC, a aquisição de 500 títulos que comporiam as referências bibliográficas constantes no ementário dos componentes curriculares.

Em relação à infraestrutura básica, o campus dispunha de laboratório de informática e também já tinha institucionalizado um grupo de pesquisa denominado Grupo de Estudos Amazônicos em funcionamento. Constava também no projeto a necessidade de construção de um prédio próprio para o pleno funcionamento do curso, o que já foi alcançado, pois, em 2016, o curso já tinha um prédio específico.

De acordo com os instrumentos de coletas de dados, aplicados à coordenação do curso, seria necessária também a abertura de processo público para contratação de docentes com formação específica, o que vem sendo realizado desde 2010 .

\section{Considerações finais}

Vimos que o acesso de indígenas à educação superior tem sido possibilitado, em sua maioria, no caso mais específico de instituições públicas, por meio dos programas de formação de professores. No entanto, nas faculdades privadas também há ingresso de indígenas. 
O fato de Rondônia ser um Estado novo, com apenas 30 anos de emancipação política, é razoável que ainda esteja à procura de sua verdadeira vocação. Mas a questão que envolve a educação terá que permear em todos os âmbitos, visto que no Estado de Rondônia se faz presente uma concentração de terras e povos indígenas que resistiram e mantêm parte de sua cultura e identidade até o presente momento.

No decorrer da realização do estudo, e de acordo com as literaturas consultadas, constatou-se que os povos indígenas foram alvos de massacres desde a presença dos colonizadores portugueses e ainda são, no momento atual. Recentes conflitos ocorridos em alguns Estados da região Norte denunciam que as determinações legais, dispostas em nossa Carta Magna, estão longe de serem cumpridas, e a voz indígena longe de ser ouvida.

Percebe-se também que, sem desconsiderar o recorte temporal, ou seja, os dados de matrículas de indígenas na educação superior em Rondônia limitam-se ao ano de 2011, as IES particulares têm, nesse sentido, representado papel social importante, pois em seus espaços podem promover ações para mitigar os problemas socioconômicos dos povos indígenas, visto que existem lacunas que as instituições públicas presentes no Estado ainda não alcançaram.

A implantação do curso de licenciatura em educação básica intercultural apontou um avanço na direção das necessidades por educação superior para os povos indígenas, e também pelo caráter social que a educação intercultural promove entre os povos, a superação dos obstáculos, quebra de paradigmas.

\section{Referências}

BRASIL, Ministério da Educação e do Desporto. Conselho Nacional de educação. Lei $10.172 / 2001$.

CARVALHO, Joêmia Batista de. Terra Indígena Raposa Serra do Sol. Disponível em: <http://www.socioambiental.org >. Acesso em 20 mar.2012. 
COSTA, Regina A. Políticas Públicas de Acesso e Permanência de Indígenas no Ensino Superior em Rondônia. 2012. Dissertação (Mestrado), apresentada ao Programa de Pós-Graduação Stricto Sensu em Educação, Mestrado Acadêmico em Educação, da Fundação Universidade Federal de Rondônia. Porto Velho, 2012.

ESTUDANTES INDÍGENAS NO ENSINO SUPERIOR: O Programa de Acesso e Permanência na UFRGS. Maria Aparecida Bergamaschi - Universidade Federal do Rio Grande do Sul (UFRGS) Andreia Rosa da Silva Kurroschi - Universidade Federal do Rio Grande do Sul (UFRGS) Políticas Educativas, Porto Alegre, v. 6, n.2, p. 1-20, 2013 - ISSN: 1982-3207.

FERREIRA, Leidiane da Silva. A inserção do Indígena no Ensino Superior em Porto Velho - RO. Disponível em: <http://www.webartigos.com>. Acesso em 20 maio 2011.

FREIRE, Paulo. Pedagogia do oprimido. 41. ed. Rio de Janeiro: Paz e Terra, 2005.

FREIRE, Paulo. Educação como prática da liberdade. 14. ed. São Paulo: Paz e terra, 2011.

FUNDAÇÃO UNIVERSIDADE FEDERAL DE RONDÔNIA - UNIR. Projeto Pedagógico de Curso. Ji-Paraná-RO, 2008.

LUCIANO, Gersem dos Santos. O Índio Brasileiro: o que você precisa saber sobre os povos indígenas no Brasil de hoje. Coleção Educação para todos, v. 12. Brasília: Ministério da Educação, Secretaria de Educação Continuada, Alfabetização e Diversidade; LACED/ Museu Nacional, 2006.

NEVES, Josélia Gomes. A UNIR e os Povos Indígenas de Rondônia: a invisibilidade do tema nas pautas dos reitoráveis na eleição 2012. In: TUDORONDONIA.COM. Disponível em: <http:// www.tudorondonia.com.br/noticias/a-unir-e-os-povos-indigenas-de-rondonia-a-invisibilidade-do-tema-nas-pautas-dos-reitoraveis-na-eleicao-2012-,26907.shtml>. Publicado em 27 fev.2012. Acesso em: abr. 2015.

RIBEIRO, Maria Luisa S. História da educação brasileira. A Organização escolar. 19. ed. São Paulo: Autores Associados, 2005.

SINDICATO DAS MANTENEDORAS DE ENSINO SUPERIOR. Mapa do Ensino Superior no Brasil. Disponível em: <http://convergenciacom.net/pdf/mapa-ensino-superior-brasil-2015.pdf>. Acesso em: nov. 2016.

UNESCO Conferência Mundial sobre Ensino Superior 2009: as novas dinâmicas do ensino superior e pesquisas para a mudança e o desenvolvimento social (Paris, julho de 2009). Disponível em: <http//:www.aplicweb.feevale.br>. Acesso em: mar. 2012.

VENERE, Mario Roberto. PROJETO AÇAÍ: uma contribuição à formação dos professores indígenas no Estado de Rondônia. Tese (Doutorado). 2011. UNIVERSIDADE ESTADUAL PAULISTA “JÚLIO DE MESQUITA FILHO”. Faculdade de Ciências e Letras - Campus de Araraquara - SP, 2011. 


\title{
5. O POVO INDÍGENA ARARA-KARO DE RONDÔNIA: CENÁRIOS HISTÓRICOS E A COLONIZAÇÃO NA AMAZÔNIA BRASILEIRA
}

\author{
Maria Isabel Alonso Alves (UFAM /PPGE/UCDB) \\ Heitor Queiroz de Medeiros (PPGE/UCDB)
}

\section{Introdução}

Trata-se de um desdobramento de pesquisa no âmbito do Programa de Pós-Graduação em Educação da Universidade Católica Dom Bosco PPGE/UCDB que objetiva verificar a produção das identidades/diferenças das mulheres/professoras/indígenas da etnia indígena Arara-Karo, localizada no município de Ji-Paraná, Estado de Rondônia, Brasil. Este texto apresenta um breve cenário histórico sobre a constituição do povo Arara-Karo e sua relação com o processo de colonização da Amazônia brasileira. São reflexões que buscam se aproximar das questões ligadas à colonização da região amazônica. $\mathrm{O}$ argumento principal do texto refere-se à ideia de que os deslocamentos e as ressignificações nos modos de organização, no contexto social ou cultural das populações indígenas, especificamente os Arara-Karo, foram intensificados com o processo de colonização. A produção de dados desta pesquisa se constitui de revisões bibliográficas a respeito do processo de colonização amazônica, considerando a colonização na constituição recente do povo Arara-Karo, bem como de entrevista narrativa com uma professora Arara-Karo. Vale ressaltar que este texto foi publicado na Revista Série-Estudos no ano de 2016. O texto em questão apresenta possibilidades de entender a relação do processo de colonização Amazônica no Brasil com a história e constituição do povo Arara-Karo, especificamente fatos históricos que compõem possíveis deslocamentos (físicos e culturais) dessa etnia indígena. Como estratégia de pesquisa, destacamos a utiliza- 
ção de estudos bibliográficos que representam a possibilidade de revificar alguns argumentos disponíveis sobre a história regional que contempla a história dos povos indígenas presentes na Amazônia legal brasileira, dentre os quais destacamos Becker (2005); Neves (2009), Fonseca (2008) e outros. Também destacamos a entrevista narrativa, segundo as abordagens metodológicas apontadas por Andrade (2012), a qual afirma que a produção do sujeito se dá no âmbito da linguagem, na relação com as forças discursivas que o nomeiam e governam, $[\ldots]$ no qual se produz e se nomeia o sujeito (ANDRADE, 2012, p. 174). Tendo em vista a possibilidade do estudo sobre o povo indígena Arara-Karo, os cenários e a colonização amazônica, utilizamos conceitos que buscam inferir os processos de colonização da Amazônia, levando em consideração os povos indígenas presentes. Assim, o texto em questão aborda de forma breve a história da colonização Amazônica, do povoamento não indígena e da localização atual onde se encontra a cidade de Ji-paraná, além de discorrer sobre os modos de vida Arara-Karo de Rondônia.

\section{As implicações da colonização na constituição da Amazônia legal Brasileira}

A origem do sistema-mundo capitalista foi produzida pela competência econômica interimperial entre os europeus no final do século XV, a partir da expansão colonial europeia, pela necessidade de encontrar mais rotas para o comércio com o oriente, o que, na perspectiva eurocêntrica, levou ao chamado descobrimento da Américas, produzido pela colonização espanhola e portuguesa (GROSFOGUEL, 2007). Na mesma perspectiva de pensar a colonização, Castro-Gomes (2007, p. 14) afirma que "a maioria das análises do sistema-mundo enfocam a divisão internacional do trabalho e das lutas geopolíticas constitutivas dos processos de acumulação capitalista mundialmente."

$\mathrm{O}$ conceito de sistema-mundo aqui utilizado refere-se, assim como Castro-Gomes (2007), às ideologias globais de desenvolvimento, cujo cen- 
tro está no poder colonial articulado a uma hierarquia racial/étnica global e suas classificações binárias, destacando as hierarquias superior/inferior; desenvolvido/subdesenvolvido; civilizado/selvagem, entre outras.

Os apontamentos de Grosfoguel (2007) e Castro-Gomes (2007) dão pistas de que, na perspectiva de atender as prerrogativas postas pela ocidentalidade (necessidades mercantis das coroas europeias), se deram os primeiros avanços às fronteiras amazônicas que, a partir de então, passou a ser considerada como o eldorado brasileiro, onde os desejos de dominação local, econômico e cultural da ocidentalidade puderam se tornar realidades. A Amazônia, além de ser vista como um local paradisíaco capaz de fazer prosperar em riquezas e poder, satisfazia as necessidades do hipotético sistema-mundo idealizado pelos colonizadores europeus. Densos argumentos da geógrafa brasileira Berta Becker (2005) mostram que

A Amazônia, o Brasil, e os demais países latino-americanos são as mais antigas periferias do sistema mundial capitalista. Seu povoamento e desenvolvimento foram fundados de acordo com o paradigma de relação sociedade-natureza, que Kenneth Boulding denomina de economia de fronteira, significando com isso que o crescimento econômico é visto como linear e infinito, e baseado na contínua incorporação de terra e de recursos naturais, que são também percebidos como infinitos. Esse paradigma da economia de fronteira realmente caracteriza toda a formação latino-americana. (BECKER, 2005, p. 72).

A história da colonização amazônica, como também mostra Bentes (2006), infere que o processo de ocupação da Amazônia, especificamente a Amazônia brasileira, está arraigado a diferentes momentos, sendo constituídos de três períodos, conhecidos como: o período de reconhecimento e descrição do universo fantástico, a partir do século XVI; o período de integração em fins do século XIX; e o período de colonização e expropriação desencadeado na segunda metade do século XX (BENTES, 2006).

O período fantástico corresponde às primeiras imagens da Amazônia, considerada um suposto paraíso terreno, descrito por aventureiros europeus 
que acreditavam ter localizado o paraíso na terra, "um lugar fantástico, ou ainda, a entrada principal do jardim do Éden” (GONDIM, 2006). A esse respeito, Gondim (2006) aponta que,

O fascínio da visão inaugural completa-se com o prodígio da terra e a temperança do ar. Terras e céus - o alto e o baixo - se encontram na diversidade do espetáculo novo e se unem em um todo harmonioso de vales, rios, montes, selvas, fontes, colinas, distribuídos em espaços ilimitados, ocupados por homens, feras, raízes curativas e alimentícias, mares piscosos, árvores frutíferas, ouro, pérolas. A ante-sala do Éden tem sua antítese no Velho Mundo (GONDIM, 2006, p. 52).

As descrições fantásticas a respeito da Amazônia e dos potenciais econômicos igualmente fantásticos desses espaços trouxeram um contingente substancial de pessoas a essa parte do Brasil. Sobre a existência e passagens de Europeus pelos territórios amazônicos, Holanda (2000,p. 31), descreve que,

Foi às beiradas daquele ri-mar, porém e quando pela primeira vez na História um bando de espanhóis o cursou em sua maior extensão até chegar a embocadura, que elas vieram a ganhar corpo. Tendo saído do Quito em 1541 rumo ao imaginário país da Canela, Francisco de Orellana e seus companheiros, antes de alcançar o Maxifaro e a terra dos Omagoa, foram avistados pelo velho cacique Aparia de que, águas abaixo, no grande rio, se achava Amazonas.

Também Bentes (2006), com relação às primeiras imagens da ocupação da Amazônia brasileira, afirma que "a primeira tentativa de penetrar no interior da atual Amazônia foi feita pela expedição de Alonso Mercadillo, em 1538, com o objetivo de conquistar as riquezas que se imaginava existir nos territórios dos índios Chupacho e Iscaicinga, nas vertentes orientais dos Andes" (BENTES, 2006, p. 9). As descrições e afirmativas postas mostram que o processo histórico da colonização amazônica, a princípio, se deu com o objetivo de exploração comercial e territorial que pudesse alimentar as ambições mercantis da Europa. As primeiras visões da Amazônia foram 
marcadas pelas descrições fantásticas e pela comparação dos espaços observados ao paraíso historicamente descrito nas narrativas literárias europeias.

O período de integração, em fins do século XIX, refere-se, entre outros momentos, ao chamado ciclo da borracha. A produção da borracha deu início ao desenfreado povoamento de pessoas não indígenas na Amazônia brasileira. A borracha é um tipo de goma elástica extraída da seringueira, árvore nativa da região amazônica, também conhecida cientificamente de Hevea brasiliensis. A seiva que a seringueira produz é a matéria prima da borracha, denominada látex ou seringa (FONSECA, 2008). O extrativismo descomedido do látex amazônico ficou conhecido como primeiro e segundo ciclos da borracha (FONSECA, 2008).

O primeiro ciclo aconteceu no início do século XIX, período em que a extração da borracha fazia parte da economia da região, sendo considerada uma "atividade artesanal, e secundária, na economia da região, que era a produção de artigos de borracha para a exportação" (FONSECA, 2008, p. 62). Era um importante produto artesanal extraído no Brasil e comercializado em outras partes do mundo, sendo a matéria prima para fabricação de artefatos de exportação, tais como botas, seringas e outros produtos impermeáveis; entretanto, sua qualidade ainda era baixa, pois amolecia com o calor e endurecia com o frio, quebrando facilmente, o que prejudicava a comercialização do produto.

Com o passar do tempo, já no considerado segundo ciclo da borracha, o látex extraído passou a ser vulcanizado ${ }^{1}$, e isso incorreu no aprimoramento do produto. A borracha passou a ser utilizada na fabricação de "pneus de carros e bicicletas; mangueiras de água e capeamento de fios elétricos, além os tradicionais impermeáveis" (FONSECA, 2008, p. 62). A borracha aparece no cenário brasileiro como um fator de economia muito forte, entretanto sua produção foi controlada e monopolizada pelo capital estrangeiro que viabilizava desde o contingente humano - os seringueiros que faziam a extração do látex na floresta - até a comercialização do produto para as grandes indústrias nacionais e internacionais.

\footnotetext{
${ }^{1}$ Vulcanizar é combinar a borracha com o enxofre para torná-la mais resistente ao calor e ao frio, mantendo sua elasticidade (FONSECA, 2008, p. 62).
} 
Pelo que expõe Castro-Gomes (2007, p. 14), entendemos que a maioria das análises do sistema-mundo enfoca a divisão internacional do trabalho e das lutas geopolíticas constitutivas dos processos de acumulação capitalista, mundialmente. Nessa perspectiva, a exploração econômica e cultural da Amazônia brasileira foi um dos aportes do consumo gerado pelo sistema-mundo.

A manifestação da colonização vinculada ao sistema-mundo pode ser observada no trecho da obra literária - poesia de cordel intitulada $O$ cancioneiro do Vale do Madeira, do poeta portovelhense Doca Brandão. $\mathrm{Na}$ obra, o poeta, ao retratar épocas dos seringais, mostra a forma de exploração do sistema-mundo em vários aspectos. Assim declama: "E a borracha aparece; No cenário brasileiro; Mas sua produção é controlada; Pelo capital estrangeiro; Que tudo monopoliza; Da colheita ao fornecimento; Pelo sistema dominante; De crédito e aviamento" (BRANDÂO, sem data, p. 31).

O trecho do poema de Doca Brandão dá pista de como o processo de colonização da Amazônia brasileira foi intenso, principalmente com relação à exploração da mão de obra dos trabalhadores nos seringais.

A colonização das áreas ocupadas por seringais não ocorreu de forma pacífica, tendo em vista que a maioria das terras onde se localizavam as florestas exploradas pertencia a grupos indígenas. À medida que os seringais avançavam em busca da borracha, ocorria expropriação dos povos originário, que ou ficavam desalojados de suas terras ou submetiam-se ao trabalho nos seringais. Os grupos que recusavam abandonar as terras ou servir de mão de obra nos seringais entravam em conflitos com os seringueiros. Foi assim que "os indígenas ilegalmente escravizados, ou semiescravizados, passaram a ocupar os seringais" (FONSECA, 2008, p. 65) para servir de mão de obra na extração da seringa. Fonseca (2008) mostra que os indígenas foram importantes para a formação dos ciclos de exploração da borracha, pois eram conhecedores das matas e sabiam a exata localização das árvores.

Se, de um lado, o processo de ocupação e exploração da borracha amazônica se constituiu com profundos impactos sobre as populações nativas, é possível dizer que, do outro, ou seja, da captura e seleção de 
mão de obra para o suposto enfrentamento da floresta, não foi diferente. Narrativas produzidas a respeito do tema informam que

Os nordestinos arregimentados não tinham a menor ideia do que era o trabalho nos seringais. Adoeciam e morriam com facilidade. Demoravam a se acostumar à solidão e à lei da mata. $\mathrm{O}$ alfaiate João Rodrigues Amaro, 72 anos, se arrependeu antes de chegar. Mas já era tarde demais. Aos 17 anos ele deixou Sobral só com a passagem de ida. A Campanha da Borracha uniu o útil ao útil. Em um ano de seca, encontrou no Nordeste um exército de flagelados pronto para partir, ou melhor, fugir. Nos postos de arregimentação, um exame físico e uma ficha selavam o compromisso. Para abrigar tanta gente - às vezes mil em um único dia -, o jeito foi construir alojamentos, como a hospedaria modelo, de nome Getúlio Vargas, em Fortaleza. Lá, eles passavam a viver até o dia da viagem, sob um forte regime militar (ARAÚJO, 2008, p. 2).

Em meio à ação colonizatória da Amazônia Legal brasileira, o processo de ocupação do estado de Rondônia - antes Território Federal do Guaporé, espaço pertencente à Amazônia brasileira - não foi diferente dos outros contextos de ocupação. Entretanto, esses processos podem ser considerados ainda mais intensos com a chegada das frentes de exploração do território pelo governo nacional, principalmente com a criação da comissão que tinha o objetivo de desbravar, percorrer e integrar a região Amazônica ao restante do país. "Durante o ciclo da borracha, todo o vale do rio Madeira e parte do vale do Guaporé formaram colônias de estabelecimentos rurais destinados à coleta da seringa, os seringais" (FONSECA, 2008, p. 65).

O estudo sobre a localização das terras indígenas do Estado de Rondônia, realizado por Santos (2014a) mostra que Rondônia está situada ao norte do Brasil, especificamente na área pertencente à Amazônia Legal. Seus limites geográficos estão entre norte e oeste com os Estados do Amazonas e Acre, bem como a leste com o Estado do Mato Grosso, fazendo divisa ao sul com a República da Bolívia, possuindo uma área de 237.590,543 km² (SANTOS, 2014a). "O Estado possui 52 muni- 
cípios, sendo a capital, a cidade de Porto Velho. A população em 2010 era 1.562.409 habitantes, 12.015 indígenas (IBGE, 2010). No ano de 2013 a população estimada foi de 1.728.214 habitantes, não sendo identificadas estimativas para o número de indígenas" (SANTOS, 2014a, P. 37-38). Tais dados encontram-se atualizados em 2015, sendo comprovado um aumento significante em sua população demográfica. Consta em 2015 uma estimativa de 1.768.204 habitantes².

O grande fluxo migratório de outras regiões do país, em decorrência da extração da borracha e, posteriormente, na década de 1970, com vistas à ocupação da Amazônia, acabou gerando conflitos em decorrência das disputas pelos espaços entre grupos indígenas que disputavam territórios entre si e, isoladamente ou em conjunto, contra a ocupação e apropriação dos não indígenas de suas terras. De acordo com Santos, (2014a, p. 43) “[...] a ocupação de Rondônia foi marcada por conflitos entre modos diferentes de organização social da vida e de apropriação sobre os recursos naturais entre indígenas e não indígenas. Antes do contato os povos indígenas viviam seus conflitos interétnicos com pouca interferência sobre o meio onde abundava as florestas densas". Registros produzidos por Souza e Pessoa (2009) afirmam que:

A produção do espaço amazônico e, especificamente, do estado de Rondônia, apresentou como características fundantes a expropriação e a violência. Para o território rondoniense, em especial, a Marcha para Oeste foi sinônimo de degradação do homem e do meio natural. Os grupos indígenas, que já vinham sendo gradativamente exterminados, a partir da década de 1960, com a colonização agrícola, passam a sofrer um impacto potencializado da relação com a Civilização do capital (SOUZA; PESSOA, 2009, p. 02).

\footnotetext{
${ }^{2}$ Fonte: IBGE, Diretoria de Pesquisas, Coordenação de Trabalho e Rendimento, Pesquisa Nacional por Amostra de Domicílios Contínua 2015. Dados extraídos do site do Instituto Brasileiro de Geografia e estatística - IBGE. Acessado em 10 de mar. de 2016. Disponível no site: http://www.ibge.gov.br/estadosat/perfil.php?lang=\&sigla=ro.
} 
As atividades econômicas marcadas pela exploração/extração da borracha na região amazônica provocou grande fluxo migratório de outras regiões do Brasil. No Estado de Rondônia, "destaca-se os seringais como atividade econômica que marcou um período de intensas movimentações de não indígenas" (SANTOS, 2014a, p. 34).

A colonização do Estado de Rondônia desencadeou processos de expropriação territorial e cultural dos povos originários, habitantes da região. Os indígenas serviram de mão de obra escrava nos seringais e, quando se recusavam, eram expulsos de suas terras, forçados a migrar para os territórios de outros grupos indígenas, o que causou conflitos e tensões entre alguns grupos étnicos amazônicos. A esse respeito, M. Arara relata que "o seringal ficava do lado dos índios, e em troca da mão de obra, estes recebiam dinheiro, tecido, gado e cachaça. Os Arara trabalhavam mais com o Firmino, o maior seringal era o Santa Maria” (M. ARARA, ENTREVISTA, 2015). Também é o caso dos Gavião-Ikolén que, ao se verem expulsos de seus territórios pelos colonizadores/seringueiros e seringalistas, adentraram o espaço territorial dos Arara-Karo. Assim conta M. Arara:

Os Gavião vieram recuados do Mato Grosso, os brancos entraram na terra deles e não quiseram mais devolver, eles vieram para cá e lutaram com os Arara para ficar na terra dos Arara. [...] há pouco tempo que a gente conversa, depois que nós tivemos um pouco de estudo, nós, eu e o Sebastião conhecemos a história e falamos para a comunidade, não vamos ficar o resto da vida brigando, vocês acolheram eles e vamos ficar os dois povos na terra, então para que ficar lembrando uma coisa que já foi [...], agora está tudo em paz (M. ARARA, Entrevista, 2015).

Devido ao processo de colonização, as duas etnias disputaram os mesmos espaços territoriais, sendo que, atualmente, Arara-Karo e Gavião-Ikolén dividem e habitam a mesma Terra Indígena - T.I. Igarapé Lourdes. Ao descrever parte da história de ocupação do espaço Amazônico, chama-se a atenção para o fato de que essas ocupações se deram em territórios anteriormente ocupados por grupos indígenas. 
A conquista territorial na Amazônia desencadeou um processo de amansamento indígena. Embora essas populações pudessem sentir-se livres, essa liberdade representava apenas certa formalidade convencional, pois não passava de condições impostas pelos colonizadores. Nessa perspectiva, “[...] todo o processo de ocupação da Amazônia tem representado uma usurpação dos territórios [...] indígenas, [...] era e é a estratégia geopolítica do confisco sumário pela força desses territórios [...]” (OLIVEIRA, 1990, p. 103).

De acordo com Teixeira e Fonseca (2001), a exploração dos territórios indígenas na região Amazônica facilitou a ocupação das áreas indígenas, o que impulsionou o intenso fluxo migratório das populações advindas das diversas regiões do Brasil, ocorrendo, assim, mais ataques e novas chacinas contra as comunidades indígenas, já bastantes pequenas. Nesse sentido, as populações indígenas foram vítimas de grileiros, posseiros, garimpeiros e seringueiros que, com ameaças e ataques, afugentavam os indígenas para outros locais, ocupando assim suas terras.

Independente da época, o fato é que o contato provocou a quase dizimação das etnias existentes na região, pois, além dos conflitos pela posse das terras, houve a propagação de doenças entre essas populações. Assim relata M. Arara:

$\mathrm{Na}$ época quando eles (os mais velhos indígenas) tiveram contato com os brancos, eles sofreram muito, foi o tempo que chegaram as doenças e eles não eram acostumados. Para eles aquilo era uma coisa nova. Para curar as doenças era só o pajé, nesse tempo adoeciam dois, três de uma vez só, assim eles foram morrendo. Assim, Os Arara passaram a viver em regime de semi-escravidão, trabalhando nos seringais, o que provocou o total desaldeamento daquele povo (PAULA, 2008, p. 27).

Trata-se de acontecimentos que ressignificaram os modos de vida da etnia em questão.

Fatos como os mencionados ocorreram com a maioria das populações indígenas que ocupavam as margens do Rio Machado. A chegada da Linha Telegráfica contribuiu para o povoamento não indígena em Rondônia e 
provocou o afastamento de algumas populações indígenas que migraram para outras localidades. No contexto de Ji-Paraná, os povos que mais sofreram com o processo de colonização foram os Arara-Karo e os GaviãoIkolen. Neves (2009, p. 25) explica que “Os Arara-Karo e Gavião-Ikolen são sobreviventes destes tempos, testemunhas das situações difíceis, confusas e violentas pelos quais passaram e que ainda são relembradas nas narrativas orais.”

\section{A contribuição da Comissão Rondon no surgimento do município de Ji-Paraná, Rondônia}

Conforme mencionado, a proposta dessa discussão é pensar a respeito do processo de colonização da Amazônia brasileira em consonância com a história e constituição do povo Arara-Karo. Tendo em vista os aspectos demográficos e históricos da região amazônica, abordamos a história a partir dos avanços da Comissão Rondon, em 1908, período em que foi dado início à construção da linha telegráfica que cortava todo o estado de Rondônia, permitindo, então, a abertura da BR 364, que favoreceu o fluxo migratório para Rondônia, o que resultou no povoamento não indígena nesse território.

O surgimento da cidade de Ji-Paraná começou em 1879, com pessoas advindas da região do Nordeste brasileiro que, ao fugirem da seca, se instalaram nessa região dando-lhe o nome de Urupá, em função da etnia indígena Urupá que habitava o atual município de Ji-Paraná (NEVES, 2009). Registros históricos (FRANCO; LACOMBE, 2001) indicam que no dia "13 de Novembro de 1908, chegou o grupo de Rondon ao cruzamento do paralelo 11 e meridiano 20. Pelas cartas deviam estar próximo a cabeceira do Jacyparaná [...] neste trecho da expedição, encontraram Miguel Sanka empregado nos seringais de Urupá, no rio Machado ou Ji-Paraná [...]” (FRANCO; LACOMBE, 2001, p. 96). Como mostram Franco e Lacombe (2001), a comitiva Rondon chegou à região onde atualmente se localiza o município de Ji-Paraná, estado de Rondônia, local antes habitados por indígenas, inclusive os Arara. 
A afirmação de que havia presença de não indígenas - seringueiros, na localização da atual cidade de Ji-Paraná,já no século XIX, é mostrada por Teixeira e Fonseca (2001, p.103) quando afirmam que "a partir de meados do século XIX e durante todo o primeiro ciclo da borracha, a oportunidade de colonização permanente da região do Guaporé e do Madeira viria concretizar-se e as margens dos rios Madeira, Ji-Paraná, Machado, Mamoré e Guaporé [que] foram ocupadas por grupos isolados de seringueiros”.

Isidoro (2006) afirma que os Arara-Karo habitavam o local onde hoje se encontram instalados: o Museu, o teatro Dominguinhos, a Matriz de São João Bosco; os Bancos - Bradesco, HSBC, Brasil e Itaú, além de comércios e praças que fazem parte do centro da cidade de Ji-Paraná. Para Isidoro (2006, p. 16), as terras tradicionais dos Arara-Karo

[...] correspondem a quase todo o território do Município de Ji-Paraná, no Estado de Rondônia. Segundo esses indígenas, havia uma grande maloca que se localizava no centro da atual cidade de Ji-Paraná, onde hoje se encontra uma das primeiras construções oficiais do município. Tal construção serviu de posto telegráfico e de alojamento para Marechal Cândido Rondon e sua comitiva no início do século XX. Nos dias atuais, funciona um museu que recebeu o nome de Marechal Cândido Rondon.

Outro documento importante sobre o processo ocupacional da região por não indígenas é descrita por Roquette-Pinto (1935), para quem, no início do século XX, a comissão Rondon “chegava às margens de um rio que se pensava ser o Jaci-Paraná, onde deveriam encontrar uma expedição enviada para esperá-lo. Mas, um erro existente nas melhores cartas, tinha-o feito chegar ao Jamari [...] todavia já caminhavam em zona de Seringueiros: havia recursos" (ROQUETTE-PINTO 1935, p. 56-57). Os documentos assinalam que durante os séculos XIX e XX havia indícios de que alguns seringueiros já habitavam a região. A comissão Rondon veio contribuir com o processo de ocupação não indígena no Estado de Rondônia.

Com a chegada da rede telegráfica, a cidade passou a ser chamada de Afonso Pena, em homenagem ao presidente da época; posteriormente, 
passou a ser chamada de Vila de Rondônia, por último, Ji-Paraná, em homenagem ao rio Ji-Paraná e, posteriormente, o mesmo rio passou a ser denominado Rio Machado, nome atual. Diante das demarcações, principalmente dos pontos telegráficos - objetivo da Comissão Rondon - foram surgindo diversos povoados que se tornaram atualmente amplos espaços urbanos, entre eles, a cidade de Ji-Paraná, que se urbanizou intensamente com a instalação de um posto telegráfico, ocupando territórios antes habitados por indígenas, inclusive os Arara-Karo, etnia sobre a qual buscaremos discorrer.

\section{4 "Nós Arara": os Karo-Rap de Rondônia}

No campo teórico dos Estudos Culturais, o conceito de identidade tem nos inspirado a perceber as diversas formas pelas quais os sujeitos se enredam, produzem e transitam em diversos modos de representação e identidade. Trata-se de uma visão que busca ver as várias formas da "produção não daquilo que nós somos, mas daquilo que nós nos tornamos" (HALL, 2013, p. 109) no decorrer da nossa história. Também com aporte em Bauman (2005), entendemos que a identidade é algo que afeta as estruturas da sociedade. As estruturas a que Bauman (2005, p. 11) se refere envolvem a produção cultural, a vida cotidiana e as relações entre o eu e o outro. Esse pensamento se dá precisamente porque “[...] as identidades são construídas dentro e não fora do discurso. Além disso, elas emergem no interior do jogo de modalidades específicas de poder e são, assim, mais o produto da marcação da diferença [...]” (HALL, 2013, p. 109).

Os autores apontam que as identidades não são um fato concluído, mas uma produção inacabada, que pode ser (re)negociada sempre dentro e não fora das representações discursivas. Nesse sentido, entendemos, assim como Hall (2013) e Bauman (2005), que a identidade não pode ser vista de forma inteiriça, fixa, mas sim como algo que se produz, se modifica nos contextos sociais e culturais e que vão sendo assumidas no decorrer da história de vida de cada sujeito. Nesse modo de pensar, cabe-nos descrever a produção identitária do povo Arara-Karo ou Karo-Rap/Nós-Arara, como preferem ser chamados. 
Nas últimas décadas, algumas pesquisas etnográficas foram desenvolvidas junto ao povo Arara-Karo. Desses estudos, alguns consistiram em entender e registrar a fonologia da língua Karo (GABAS, 1989). O idioma Karo, até 1898, a não havia sido registrado, como assegura Gabas (1989, p. 8), sendo que os pesquisadores Nimuendaju (1925), Rondon (1948), Lévi-Strauss (1950) e Schultz (1955) foram os primeiros etnólogos a documentarem o idioma Karo através de pequenas listas de palavras apenas.

O registro e sistematização fonológica da língua Karo foi efetuado somente em 1989, por Gabas. Pelo que afirma Gabas (1989), os estudos referentes a esse grupo étnico pelos etnógrafos citados eram voltados aos fatores sociais, econômicos, culturais, de localização, dentre outros, do ponto de vista da modernidade. Em tais estudos, a língua Karo aparecia mais na forma oral; , o primeiro registro fonológico da língua Karo foi feito no ano de 1989, por Gabas, linguista pesquisador da Universidade Estadual de Campinas - UNICAMPI. Vale ressaltar que, assim como Gabas, os autores por ele citados não são da região onde se localiza a etnia Arara, mas de outras localidades do Brasil e até mesmo da Europa.

Posterior à pesquisa de Gabas (1989) sobre a fonologia da língua Karo, outros estudos realizados por pesquisadores locais foram fundamentais para a compreensão da história do povo Arara-Karo. No ano de 2006, Isidoro buscou verificar a situação sociolinguística da etnia em questão e aponta a língua Karo como forma de interação social e afirmação identitária dos Arara-Karo, além de mostrar algumas relações sociais e econômicas que influenciam na constituição linguística desse povo. Em 2009, Neves, outra pesquisadora local, produziu dados empíricos a respeito da cultura escrita no contexto indígena na terra Indígena Igarapé Lourdes, local onde residem os Arara-Karo e os Gavião-Ikolen. Tal pesquisa documentou e investigou o processo de aquisição da cultura escrita das etnias citadas. Nas duas pesquisas locais, aparecem a localização, o contexto histórico de colonização, bem como a relação do povo Arara-Karo com a língua materna, o idioma Karo da família Rararáma de tronco tupi, entre outros elementos fundamentais que nos mostram os Arara-Karo de Rondônia. 
Os estudos aqui mencionados sobre os Arara-Karo de Rondônia trouxeram elementos importantes, constitutivos da história do povo Arara-Karo. De modo geral, aparecem importantes informações a repeito do grupo pesquisado e nos ajudam a conhecer a história do povo em questão, nos possibilitando novos olhares, novas interpretações. As pesquisas citadas nos auxiliam conhecer a constituição identitária do povo Arara-Karo em meio ao processo da colonização ocidental da Amazônia, foco deste excerto.

Os Arara-Karo de Rondônia também são autodenominados como Karo-Rap, que significa Nós Arara (ISIDORO, 2006). Sobre a constituição do povo Arara-Karo, Sebastião Kara’yã Péw Arara Gavião, ao ser entrevistado por Neves (2009), narra:

Somos um povo indígena, cada um de nós tem um nome diferente. Nossa autodenominação é "Karo Rap" que significa Povo Arara. Surgimos de uma pedra retirada na beira do rio. De dentro da pedra surgiu o primeiro ser humano (Arara) e depois todos os outros. Fomos chamados de Arara porque usamos muito urucum no corpo durante as festas. Os não indígenas nos achavam parecidos com a cor das penas de arara e assim passaram a nos chamar (NEVES, 2009, p. 2).

O Arara-Karo é um povo falante do idioma Karo e preza pela manutenção da língua materna. É provável que o idioma Karo seja o único idioma da família linguística Ramaráma de tronco Tupi no Brasil, pois, como afirma Gabas $(1989$, p. 8) “[...] o Karo e o Itogapúk são os únicos membros sobreviventes, uma vez que os Urumi e o Ramaráma já desapareceram.” Para Gabas (1989), a comunicação entre os Arara-Karo no contexto da etnia (em reuniões do grupo, conversas entre os pares Arara e outros momentos) é feita exclusivamente na língua Karo, ficando a língua portuguesa para a comunicação fora do contexto Arara ou em conversas com não indígenas. Mesmo em rodas de conversas em que estão presentes os Arara-Karo e não indígenas, a comunicação entre os pares ocorre na língua Karo e em português com os demais (GABAS, 1989). Assim afirma:

Com relação à situação linguística dos Arara, pude constatar que ela é bastante homogênea: na comunicação entre eles é usado 
exclusivamente o idioma Karo. Apenas nas situações de interação com o branco (chefe do posto, encarregado da FUNAI, comerciantes de Ji-Paraná, etc.) a língua é falada em português, sendo os homens seus únicos falantes usuários - embora as mulheres entendam bem o português, elas não a falam (GABAS JR, 1989, p. 10).

Buscamos em Lopes (2010) a afirmação de que as identidades se constroem (ou são assumidas) por meio do processo de construção dos significados linguísticos, de modo que os indivíduos vão se produzindo, vão construindo suas identidades. Os Arara de Rondônia, ao se assumirem Karo-Rap ou Nós Arara, afirmam suas identidades étnicas, locais, territoriais, linguísticas e outras identidades.

Os Arara-Karo habitam a Terra indígena (TI) Igarapé Lourdes localizada na região do Município de Ji-Paraná, Rondônia e se dividem em duas aldeias, Iterap e Paygap. Na aldeia Iterap,

[...] as pessoas estão distribuídas em pequenos núcleos, distantes entre 300 e 800 metros uns dos outros, compostos por várias casas que contém, cada uma, uma família nuclear que compartilha com as demais um terreiro e uma cozinha. Cada núcleo comporta um casal mais idoso, seus filhos e filhas solteiros, filhos recém-casados com suas esposas e filhos e, mais raramente, filhas recém-casadas, configurando uma família extensa distribuída em várias casas contíguas (SANTOS, 2014b, p. 155 - grifo da autora).

Santos (2014b, p. 156) ainda afirma que a aldeia Paygap é menor, habitada pela família pais, irmãos e irmãs da esposa do cacique da aldeia, senhor P. Arara ${ }^{3}$, entretanto, a organização nuclear das famílias ocorre da mesma forma que a Iterap, onde o "[...] esquema de residência em casas compostas por famílias nucleares se repete, mas as casas são bem mais próximas umas às outras e, embora os descendentes do cacique sejam

\footnotetext{
${ }^{3}$ P. Arara é cacique da aldeia Paygap, "Há cerca de dois anos, os diversos núcleos residenciais de Iterap solicitaram à FUNAI o reconhecimento como aldeias independentes e "elegeram", cada um, um cacique", conforme afirma Santos (2014b, p. 139, 156), Atualmente os caciques são P. Arara cacique da Paygap e M. Arara da Iterap.
} 
maioria e ocupem mais casas, o discurso de que ali vive uma só família é bem difundido."

De acordo com Paula et al (2010), os integrantes da aldeia Paygap se deslocaram da aldeia Iterap como forma de proteção à terra indígena "das constantes invasões dos migrantes que se dirigiam para Rondônia na década de 1980" (PAULA et al, 2010, p. 1). Era uma estratégia para não serem atacados todos de uma única vez, dando-lhes a chance de proteção. Nas duas aldeias vive uma população de pouco mais de trezentas e quarenta e seis pessoas ${ }^{4}$, sendo cento e oitenta mulheres e cento e sessenta e seis homens, além de quatorze crianças na faixa etária de nove anos e quarenta e nove crianças entre dez e quatorze anos. As demais faixas etárias não foram informadas.

De acordo com Instituto Socioambiental (ISA, 2015), dois terços dessa população vivem na aldeia Iterap e os demais na aldeia Paygap. A cidade mais próxima das duas aldeias é Ji-Paraná, que se encontra cerca de setenta $\mathrm{km}$ de distância, por rodovia, da aldeia mais distante - a Iterap, ou três horas de barco descendo pelo Rio Machado e subseguindo pelo Rio Prainha (que deságua no Machado). Para a aldeia Paygap, o acesso é por terra e fica aproximadamente a cinquenta $\mathrm{km}$ de distância da cidade.

Vale ressaltar que a T.I. Igarapé Lourdes também é ocupada pela etnia Gavião, com quem os Arara mantêm relações instáveis (SANTOS, 2014b, p. 147), sendo que as duas etnias - Arara e Gavião - dividem o mesmo território. Santos (2014b, p. 138) afirma que “[...] os Arara habitam desde tempos imemoriais a bacia do Rio Machado, afluente da margem direita do Rio Madeira, no estado de Rondônia, e compartilham com os Gavião a Terra Indígena Igarapé Lourdes, no município de Ji-Paraná.”

A área total da T.I. Igarapé Lourdes tem aproximadamente 190.000 hm2 de extensão, e cerca de um terço dessa área pertence aos Arara-Karo. A respeito da localização das terras indígenas pertencentes aos Arara-Karo na década de 80, Gabas $(1989$, p. 8) assim descreve:

\footnotetext{
${ }^{4}$ Informações fornecidas pela Cacique M. Arara em conversa no dia 22 de abril de 2015, na sala do GPEA (Grupo de Pesquisa em Educação na Amazônia) no âmbito da Universidade Federal de Rondônia-UNIR.
} 
Os Arara vivem, juntamente com os Gavião e alguns Zoró, na área indígena Igarapé Lourdes, na região centro-leste de Rondônia. A área compreende três aldeias distintas: a do Lourdes, onde vivem apenas índios Gavião, a de Nova Colina (ou Ikolén), onde vivem Gavião, Zoró e apenas um Arara; e a aldeia da Triangulina (ou Iterap), onde vivem os Arara.

Gabas (1989) denomina de aldeia Triangulina a aldeia Itepap, local onde reside parte dos Arara-Karo. Destaque-se que Triangulina foi uma empresa (rede de supermercados que não existe mais) em Ji-Paraná e demais municípios de Rondônia na década de 1980. Seus donos possuíam, além do comércio, grandes áreas de terras (fazendas) nas redondezas de Ji-Paraná, portanto, suas terras cercavam a aldeia Iterap, que ficou conhecida como aldeia da Triangulina. Conforme explica gabas (1989),

A aldeia da Triangulina é formada por duas sub-aldeias distintas: a do 'centro' - denominação do chefe do posto e dos próprios índios - localizada mais ao centro da área, de onde os Arara extraem os principais produtos (borracha, caucho e castanha) que comercializam na cidade de Ji-Paraná; e a aldeia do 'posto' localizada o sul da área, próximo à desembocadura do Igarapé Prainha no rio Machado (ou rio Ji-Paraná), onde se localiza o posto da aldeia (GABAS JR, 1989, p. 9).

A respeito da localização do povo Arara na atualidade, M. Arara, em uma de suas narrativas (ENTREVISTA, 2015), conta que somam nove aldeias distribuídas em torno da aldeia central, a Iterap 1:

Hoje nós temos aqui um total de nove aldeias Araras. Aqui onde estamos é a aldeia e Iterap 1, no alicate é a aldeia Iterap 2, tem a aldeia do Chapinha que é a Prainha, tem aldeia do Pelado, aldeia Cafezinho, a aldeia Patuasal, aldeia Cachoeirinha, aldeia Postinho e a aldeia Galhada. A única aldeia que tem uma escolinha é a Prainha, de todas as outras, as crianças vem estudar aqui na Iterap 1.

A descrição do espaço onde se localizam as aldeias do povo AraraKaro, realizada no ano de 1989, leva à compreensão de que, possivelmente, o que o autor chama de Triangulina pode ser uma das fazendas pertencentes 
ao dono da rede de supermercados na época, podendo ser considerada, hoje, a mesma fazenda M. P. ${ }^{5}$ que cerca parte das T.I do Igarapé Lourdes, especificamente a aldeia Iterap onde vive parte dos Arara-Karo, conforme observado e registrado no caderno em campo, em dezembro de 2015:

O acesso via estrada de chão às Terras Indígenas Igarapé Lourdes, especificamente à aldeia Iterap, é restrito. Parte da Terra Indígena Igarapé Lourdes é cercada por várias fazendas. Entre as fazendas, há uma grande área de terra conhecida pelo nome de seu proprietário M. P. A fazenda M. P. cerca parte das Terras Indígenas (TI) do Igarapé Lourdes. Há cercas de arame liso e farpado com várias porteiras de madeira e arame que broqueiam o caminho, mas não estão trancadas [...] (ALVES, M. A. A. Caderno de Campo, dez de 2015').

Com relação à descrição anterior, $\mathrm{M}$. Arara relata que as porteiras ficavam trancadas com cadeados e, para o acesso à Terra Indígena, era preciso se deslocar a pé até a sede da fazenda para retirar as chaves das porteiras com o capataz e devolvê-las em seguida, o que causava transtornos aos indígenas e demais pessoas que transitavam na região. M. Arara afirma que isso ocorreu por muito tempo, até que houve um desentendimento entre um indígena Arara e o capataz da fazenda por conta da insatisfação do indígena com tal situação. Nessa ocasião, o indígena Arara foi assassinado pelo capataz da fazenda, o que causou revolta na comunidade. A partir de então, as porteiras passaram a ficar escancaradas ou apenas encostadas, sem necessidade de chaves para abri-las. O relato de M. Arara nos conta um pouco de suas angústias como mulher e liderança indígena frente à situação de tomada das terras de seu povo.

A respeito das implicâncias da colonização ocidental no contexto do povo Arara-Karo, M. Arara relata que foi um processo de muito sofrimento. Assim narra:

\footnotetext{
${ }_{5}^{5}$ M. P. refere-se às iniciais do nome do proprietário da fazenda que cerca a T.I Igarapé Lourdes. A fazenda tem o nome do dono.

6 Trata-se de resultados parciais (ainda não divulgados) da pesquisa de doutorado em andamento no Programa de Pós-Graduação em Educação da Universidade Católica Dom Bosco - PPGE/UCDB.
} 
Os não indígenas mataram nossos parentes e os que sobraram contam essa história de sobrevivência, os velhos contam que sofreram muito, andaram muito. Até na minha época mesmo, nós vivíamos andando, não era como hoje. Nós moramos muito tempo no seringal, nossos pais cortavam seringa depois de muito tempo é que nós viemos para cá ( $M$. ARARA, ENTREVISTA, 2015).

Segundo M. Arara, no processo de colonização ocidental na Amazônia brasileira, as mulheres Arara-Karo sofriam nos/com os conflitos. Os homens iam para as frentes de batalha em defesa das terras e das vidas Arara-Karo, e as mulheres que ficavam nas aldeias eram violentadas pelos não indígenas. Muitas crianças na época dos conflitos por terras ficaram órfãs ou foram deixadas para trás nas fugas, sendo que muitas delas acabaram sendo adotadas, criadas pelos não indígenas seringueiros da região.

Às vezes, a pessoa adoecia e eles (os parentes) largavam para trás, se escapar, escapou, então era assim, ninguém ficava parado em um canto. É por isso que esses meninos que eram criados com o branco foram largados, não é que os parentes não gostavam, mas estavam eles correndo perigo e largavam as crianças. [...] Aprendi muito com a minha mãe, todo tempo fui curiosa, eu perguntava: Como que era isso? Porque matavam crianças que nasceram deficientes? Ela me respondia que antigamente eles estavam sempre fugindo e, às vezes, largavam as crianças que estavam doentes. De repente vinha um invasor que os atacava e eles tinham que fugir. De todo jeito as crianças iam morrer e quando a mãe morria, eles (os parentes indígenas) matavam as crianças porque não tinham como cuidar. Algumas crianças que escaparam foram adotadas por alguns seringueiros (M. ARARA, ENTREVISTA, 2015).

Os relatos de M. Arara narram suas angústias de mulher indígena que busca compreender a história do seu povo em meio ao processo de colonização a Amazônia. Fatos como os narrados possibilitam a compreensão de que as lutas pelas terras foi um dos movimentos marcantes para a constituição identitária do povo Arara-Karo. Assim entendemos que o território Arara é muito mais que apenas terras de onde retiram alimentos ou recursos para subsistência, mas um local de cultura, de afirmação identitária e constituição do próprio povo Arara. 


\section{Considerações finais}

Este estudo mostra que o norte se apropriou das riquezas dos países do sul por meio da exploração e dominação. No caso da Amazônia brasileira, isso pode ser observado com relação à tentativa de extermínio dos povos indígenas pela expropriação territorial e cultural dos mesmos no período de colonização. Os autores da modernidade/colonialidade nos dão pistas de que a colonialidade global ainda permanece e não pode ser vista ou reduzida à presença ou ausência de administradores coloniais.

A eliminação das administrações não elimina a descolonização do mundo, inclusive dos povos indígenas. Ou seja, acreditar em um mundo pós-colonial significa dizer que já não ocorrem processos colonizatórios, porém as múltiplas e heterogêneas estruturas de poder relacionadas aos mais de 500 anos de história do Brasil não se evaporam com a não presença administrados coloniais. As lutas contra as novas formas de colonização e as lutas antirracistas, étnicas, de gênero e outras, contra a supremacia branca europeia, podem servir para unificar os povos contra o inimigo comum: o sistema-mundo.

Com relação ao processo de colonização da Amazônia brasileira e suas implicações na constituição do povo Arara-Karo, é possível perceber que a intensificação e interesse pela região Amazônica se deram não apenas em função das demarcações de limites, mas, sobretudo, na intenção de tornar o espaço amazônico produtivo para alimentar o mercado de capitais.

Com referência a esse processo integracionista, destacaram-se as diversas missões e expedições sobre o território amazônico, como, por exemplo, a comissão Rondon que, no início do século XX, percorreu grande parte do Norte Brasileiro na tentativa de viabilizar a comunicação e o deslocamento de pessoas e produtos extraídos da Amazônia, como, por exemplo, a borracha. Em meio ao processo colonizatório, os Arara-Karo foram ressignificando seus modos de vida e reorganizando seus espaços. 


\section{Referências}

ANDRADE, S. S. A entrevista narrativa ressignificada nas pesquisas educacionais. In: MEYER, D.E.; PARAÍSO, M. A. Metodologias de pesquisas pós-críticas em educação. Belo Horizonte: Mazza edições, 2012, p. 173-194.

ARARA, Marli. Entrevista Narrativa [15 de dezembro, 2015]. Ji-Paraná, Rondônia. Entrevista Concedida a Maria Isabel Alonso Alves.

ARAÚJO, Ariadne. Batalha da Borracha. Revista Primeira Versão. Ano VII, v.23, n. 233, set./dez. Porto Velho, 2008.

BAUMAN, Zygmunt. Identidade. Rio de Janeiro: Zahar, 2005.

BECKER, Bertha K. Geopolítica da Amazônia. Revista Estudos Avançados. v..19, n. 53, p.71-86, 2005.

BENTES, Dorinethe dos Santos. As Primeiras Imagens da Amazônia. Manaus: Centro Cultural dos Povos da Amazônia, 2006.

BRANDÂO, Doca. O cancioneiro do Vale do Madeira. In: Cordel Temático Rondônia História Regional. Porto Velho, [s.n.] 2000.

CASTRO GÓMEZ, Santiago; GROSFOGUEL, Ramón. Prólogo. Giro decolonial, teoria crítica y pensamiento heterárquico. In: CASTRO GÓMEZ, Santiago; GROSFOGUEL, Ramón. El giro decolonial. Reflexiones para una diversidad epistémica más allá del capitalismo global. Colombia: Siglo del Hombre Editores, 2007 (p. 9-24).

FRANCO, Afonso A. de Mello; LACOMBI, Américo Jacobino. Marechal Rondon. São Paulo: Três, 2001.

FONSECA, Dante Ribeiro da. Rondônia, sua história e sua gente. Curitiba: Base Editora, 2008.

GABAS, Nilson, Jr. Estudo fonológico da língua Karo (Arara de Rondônia). Dissertação (Mestrado em Linguística)-UNICAMPI, Campinas, 1989.

ISA. Instituto Socioambiental. Povos indígenas no Brasil. Disponível em: <http://pib.socioambiental.org/pt/povo/karo >. Acessado em: 20 abr. 2015.

GONDIM, Neide. A invenção da Amazônia. São Paulo: Marco Zero, 2006.

GROSFOGUEL, Ramón. Descolonizando los paradigmas de la economía política: transmodernidad, pensamiento fronterizo y colonialidad global. In: GROSFOGUEL, MALDONADO TORRES, Unsetling postcoloniality: coloniality, transmodernity and border thinking. Estados Unidos: Duke University Press, 2007. Disponível em <http://www. manuelugarte.org/modulos/biblioteca/g/ramon_grosfoguel_descolonizando_paradigmas_ economia_transmodernidad.pdf $>$. Acessado em: 29 abr. 2016. 
HALL, Stuart. Quem precisa da identidade? In: SILVA, Tomaz Tadeu da (Org.). Identidade e diferença: a perspectiva dos estudos culturais. 12. ed. Petrópolis, RJ: Vozes, 2013.

HOLANDA, Sergio Buarque de. Visão do Paraíso: os Motivos Edênicos no Descobrimento e Colonização do Brasil. São Paulo: Brasiliense, 2000.

ISIDORO, Edinéia Aparecida. Situação sociolinguística do povo Arara: uma história de luta e resistência. 2006. Dissertação (Mestrado em Letras) - UFG, 2006.

LOPES, Luiz Paulo da Moita; BASTOS, Liliana Cabral (Orgs). Para Além da Identidade: fluxos, movimentos e trânsitos. Belo Horizonte: UFMG, 2010.

NEVES, Josélia Gomes. Cultura Escrita em Contextos Indígenas. 2009. Tese (Doutorado em Educação) - UNESP, Araraquara, 2009.

OLIVEIRA, Ariovaldo Umbelino de. Amazônia: monopólio, expropriação e conflito. Campinas, São Paulo: Papirus, 1990.

PAULA, Jania Maria de. KARO e IKÓLÓÉHJ: escola e seus modos de vida. 2008. Dissertação (Mestrado em Geografia) - UNIR, Porto Velho, 2008.

PAULA, Jania Maria de et al. O povo Arara-Karo: entre a produção tradicional e o mercado. In: Associação Nacional de Pós-Graduação e Pesquisa em Ambiente e Sociedade (ANPPAS). ENCONTRO ASSOCIAÇÃO NACIONAL DE PÓS GRADUAÇÃO E PESQUISA EM AMBIENTE E SOCIEDADE, 5, UFSC. Anais...(on line) Florianópolis - Santa Catarina - Brasil. Disponível em: <http://www.anppas.org.br/encontro5/ cd/resumos/GT14-399-392-20100520120935.pdf>. Acessado em: 29 abr. 2016.

ROQUETE-PINTO, E. Rondônia. São Paulo: BPD, 1935.

SANTOS, Alex Mota dos. Cartografias dos povos e das terras indígenas em Rondônia. 2014. Tese (Doutorado em Geografia) - UFPR, Curitiba, 2014a.

SANTOS, Júlia Otero dos. Ritual, "Cultura” e Transformação: a festa do jacaré entre os Arara de Rondônia. In: CUNHA, Manuela Carneiro da; CESARINO, Pedro de Niermeyer. (Orgs). Políticas culturais e Povos indígenas. São Paulo: Cultura Acadêmica, 2014b. (p. 135-163). 



\title{
6. CULTURA INDÍGENA NO COTIDIA- NO DA ESCOLA YWARÁ PURUBORÁ: CONTRIBUIÇÕES PARA A (RE)CONS- TRUÇÃO DA IDENTIDADE ${ }^{1}$
}

\author{
Anatália Daiane de Oliveira Ramos (PPGE/UFMT) \\ Marli Lúcia Tonatto Zibetti (PPGE/MAPSI/UNIR)
}

\section{Introdução}

O presente texto tem como objetivo descrever e analisar as formas como a cultura indígena comparece no cotidiano do trabalho pedagógico da Escola Indígena de Ensino Fundamental Ywará Puruborá, discutindo as contribuições e os limites desse trabalho para a (re)construção da identidade do povo Puruborá.

O povo Puruborá é um grupo étnico resistente e ressurgido ${ }^{2}$ do estado de Rondônia que, na década de 1990, teve negada sua identidade e, na década de 2000, ressurge e passa a lutar por seu reconhecimento perante os órgãos regulamentadores, obtendo em 2003 esse reconhecimento pela Fundação Nacional do Índio (FUNAI). Atualmente, encontra-se na luta pela revitalização da sua cultura, fortalecimento de sua identidade indígena e demarcação do seu território tradicional.

O texto foi elaborado a partir de pesquisa do tipo etnográfico, realizada na Aldeia Aperoi, constituída por um conjunto de áreas rurais localizadas às margens da BR 429, no município de Seringueiras, estado de Rondônia, que utilizou como instrumentos análise documental, obser-

\footnotetext{
${ }^{1}$ Este texto é parte da pesquisa de mestrado intitulada "Escolarização indígena e identidade Puruborá: contribuições e desafios da escola para um povo ressurgido/resistente na Amazônia", defendida junto ao Programa de Pós-Graduação em Psicologia da Fundação Universidade Federal de Rondônia (UNIR) e contou com apoio da CAPES.

${ }^{2}$ Ressurgido: "sair do anonimato", "dar-se a conhecer", "apresentar-se" e "levantar-se" como indígenas ao órgão oficial e à sociedade local, após um período sem o fazer (AMORIM, 2003; 2010).
} 
vação participante, diário de campo e entrevistas. Participaram da pesquisa 15 pessoas, sendo elas: Hozana3, cacique do povo Puruborá; Valdinei, à época chefe do Núcleo de Educação Escolar Indígena; a professora Gisele, filha de Hozana, que trabalhava com as disciplinas de Língua Portuguesa, Matemática, História, Geografia e Ciências; o professor de Língua Puruborá Mário e o professor Deivid, que substituía Gisele quando esta cursava disciplinas do curso de Licenciatura em Educação Básica Intercultural na Universidade Federal de Rondônia (UNIR); as estudantes Maria Paula, Mariana, Rafaela e Katiely; as mães das estudantes Lúcia, Dulce e Ana; e as ex-estudantes da escola Helena, Geisa e Marcela.

Para atender os objetivos do presente texto, fazemos inicialmente uma breve discussão teórica sobre identidade, chamando os autores e as autoras $^{4}$ da Psicologia Social para contribuir com essa discussão e sustentar a análise dos dados obtidos acerca do trabalho escolar na aldeia Aperoi do Povo Puruborá.

$\mathrm{Na}$ segunda seção, descrevemos e analisamos o trabalho com a cultura na escola Ywará Puruborá, destacando a centralidade do ensino da Língua Puruborá como elemento identitário. Por fim, tecemos os últimos fios do presente texto ao apresentarmos nossas considerações finais.

\section{Identidade: breve discussão}

A questão da identidade tem sido estudada por psicólogos, sociólogos, filósofos, antropólogos e diferentes cientistas sociais, além de discutida em diferentes lugares, entre eles, a escola. (CIAMPA, 2004; DANTAS; CIAMPA, 2014). Segundo Sawaia (1999, p. 21) não são necessários estudos exaustivos para constatar que a identidade "[...] é uma das idéias força da modernidade contemporânea".

\footnotetext{
${ }^{3}$ Os nomes Hozana, Valdinei, Gisele, Mário e Deivid são verídicos e foram utilizados mediante suas autorizações. Os nomes das estudantes são fictícios e foram escolhidos por elas; os demais nomes também são fictícios, mas foram escolhidos pela pesquisadora. Exceto Valdinei, Maria Paula, Katiely, Lúcia e Geisa, os e as demais são indígenas Puruborá.

${ }^{4}$ Neste texto utilizaremos a linguagem não sexista, inspirada em Freire (1993).
} 
Para Ciampa (2004), assim como o ser humano só pode se tornar humano sendo um ser social e histórico, por meio de um processo contínuo e progressivo, as possibilidades, as impossibilidades, os modos e as alternativas de sua identidade são decorrentes do contexto histórico e social em que ele e ela vivem. Assim, de acordo com o autor (2004, p. 74), "Identidade é movimento, é desenvolvimento do concreto. Identidade é metamorfose. É sermos o Um e um Outro, para que cheguemos a ser Um, numa infindável transformação.” Por isso, a identidade não deve ser vista como dada, mas como se dando em um processo contínuo de identificação, considerado o caráter de sua historicidade, uma vez que nos fazemos pela prática.

Concordamos com Ciampa que identidade é metamorfose e movimento. No entanto, julgamos que a identidade não é só metamorfose, pois existem cristalizações, ou seja, características individuais que permanecem conosco durante o decorrer da nossa existência. Segundo Maheirie (2002, p. 40), tradicionalmente o significado de identidade se refere a "[...] uma unidade de semelhanças se fechando na permanência [...]”.

Assim, apropriamo-nos das ideias de Sawaia (2001, p. 121) que identificou a "[...] existência de duas concepções antagônicas de identidade: a identidade transformação/ multiplicidade e a identidade permanência/ unicidade [...]”, sendo que, para esta autora, as concepções não se anulam e não há uma melhor que a outra, “[...] ao contrário, a tensão entre ambas permite conceber identidade como 'identificações em curso', isto é, identidade que, ao mesmo tempo que se transforma, afirma um 'modo de ser'."

Sawaia (1999, p. 21) problematizou essas concepções antagônicas advertindo que:

O problema reside na polarização e cristalização de uma delas em detrimento da outra. Quando isto ocorre, cai-se ou na esquizofrenia da "identidade volátil" que impede relações ou na cristalização da "identidade clichê" e no seu correlato de ultra investimento na diferença, na marca que separa e discrimina. Ambas matérias prima do preconceito e do fundamentalismo e cujos horizontes é a solidão. (Destaques no original). 
Assim, de acordo com esta autora é preciso manter a tensão entre esses dois sentidos do conceito de identidade (permanência e transformação) uma vez que “[...] usar a concepção de identidade como multiplicidade não é abandonar a concepção de identidade como de ser e de se relacionar como individualidade única e identificável. Sem o idêntico a si mesmo não há convivência e relação." (SAWAIA, 1999, p. 23).

Santos (2010, p. 135) também concorda que as identidades são “identificações em curso.” Segundo ele, há diferentes razões para o questionamento do conceito de identidade, dependendo de quem formula e de quais propósitos sustentam estes questionamentos:

Sabemos também que as identificações, além de plurais, são dominadas pela obsessão da diferença e pela hierarquia das distinções. Quem pergunta pela sua identidade questiona as referências hegemónicas mas, ao fazê-lo, coloca-se na posição de outro e, simultaneamente, numa situação de carência e por isso de subordinação. [...] A questão da identidade é assim semifictícia e seminecessária. Para quem a formula, apresenta-se sempre como uma ficção necessária. Se a resposta é obtida, o seu êxito mede-se pela intensidade da consciência de que a questão fora, desde o início, uma necessidade fictícia. É, pois, crucial conhecer quem pergunta pela identidade, em que condições, contra quem, com que propósitos e com que resultados.

Santos (2010) nos ajuda a compreender que a definição das identidades se dá especialmente pelos e pelas que estão na relação de dominação, uma vez que são eles e elas que precisam constantemente definir suas identidades, como, por exemplo, os e as indígenas, que "necessitam" se posicionar e buscar entender a questão cultural, social e histórica em que suas condições foram construídas, enquanto os "brancos" e as "brancas" raramente precisam pensar que eles e elas fazem parte da hegemonia. Assim, de acordo com Sawaia (1999, p. 22), este autor “[...] situa a identidade nas relações de poder e introduz a ética e a cidadania nas suas discussões, apresentando-a como categoria política e estratégia nas relações de poder.”

Sawaia (2001) também afirma que o conceito de identidade é político e deve ser situado nas relações de poder, por estar ligado à inserção 
social nas sociedades excludentes, complexas e hierarquizadas, bem como à inserção social nas relações internacionais. Para a autora (2001, p. 124):

O clamor pela identidade, quer para negá-la, reforçá-la ou construí-la, é parte do confronto de poder na dialética da inclusão/exclusão e sua construção ocorre pela negação dos direitos e pela afirmação de privilégios. Ela exclui e inclui parcelas da população dos direitos de cidadania, sem prejuízo à ordem e harmonia social.

Dessa forma, para ela $(1999$, p. 22) "Identidade esconde negociações de sentido, choques de interesse, processos de diferenciação e hierarquização das diferenças, configurando-se como estratégia sutil de regulação das relações de poder, quer como resistência à dominação quer com seu reforço.”

De acordo com Ciampa (2004), "A questão da identidade nos remete necessariamente a um projeto político" (p. 73), sendo que "Qualquer tendência, convergência ou concorrência que se arvore em verdade, em ação, em expressão definitiva e acabada de um único projeto de transformação absolutiza-se, tornando-se antidialética, anti-histórica, anti-humana.” (p. 74).

Dessa forma, o conceito de identidade que fundamentará a análise dos dados neste trabalho é de que as pessoas e os grupos se constituem por meio de características que permanecem durante a existência. No entanto, os contextos histórico, econômico, político, ideológico, psicológico, cultural e social influenciam e contribuem para que elas e eles possam ir modificando estas características fazendo o que Santos (2010) denominou de “identificações em curso". A tensão permanência/transformação não é opositiva, mas complementar, sendo necessário mantê-la, segundo Sawaia (1999). Assim, a identidade muda, por meio da apropriação ou da imposição, é ressignificada em função de várias questões, mudanças, alterações, contextos e, por isso, está em movimento.

\section{0 trabalho com a cultura indígena na escola Ywará Puruborá}

De acordo com Bosi (1996, p. 16), “Cultura é o conjunto das práticas, das técnicas, dos símbolos e dos valores que se devem transmitir às novas 
gerações para garantir a reprodução de um estado de coexistência social.” Partindo desse conceito, podemos entender a importância que a transmissão da cultura de seus ancestrais representa para a revitalização da identidade Puruborá. De fato, ao longo da história de colonização do estado de Rondônia, que culminou com a expulsão dos indígenas de suas terras e com a proibição de viver de acordo com seus costumes, os Puruborá, em decorrência dessa diáspora sofrida, deixaram de compartilhar boa parte da sua cultura com as novas gerações, que nasceram e cresceram fora de aldeias indígenas.

O reagrupamento de vários membros da etnia Puruborá em torno da terra adquirida por uma das matriarcas do grupo permitiu a organização da Aldeia Aperoi, e a luta sistemática do povo garantiu a construção da escola Ywará Puruborá. Nesse espaço buscam, de acordo com as possibilidades da professora e dos professores que nela atuam, resgatar aspectos de sua cultura com vistas a contribuir para a revitalização da identidade do grupo.

Durante nossa permanência na Aldeia Aperoi e acompanhamento do cotidiano escolar, percebemos que a professora Gisele e os professores Mário e Deivid, ao serem questionados sobre o trabalho com a cultura de seu povo na escola, centralizam a discussão em torno da Língua Puruborá. Assim, embora recolham e transmitam outras práticas culturais na escola, parecem entender que o que torna a escola indígena são as aulas de Língua Puruborá.

Embora a Língua Puruborá seja considerada quase extinta do ponto de vista linguístico (MONSERRAT, 2002), para os e as indígenas ouvidos em nossa pesquisa ela é considerada como língua materna e um elemento identificador da identidade desse povo. Conforme afirma o professor Deivid, se o estudante tiver aulas apenas de Língua Portuguesa e esquecer a língua materna, não terá acesso à sua própria raiz. (Entrevista Deivid,11/09/2014).

Da mesma forma que aponta Freitas (2003) em sua pesquisa com o povo Makuxi, a língua é vista pelos e pelas participantes como um símbolo, um ícone utilizado para preservação identitária, que fortalece a luta pelos seus direitos, inclusive o territorial. Nesse sentido, ao apoiar-se na Língua Puruborá como um elemento da cultura, como um símbolo de sua identidade indígena e como uma forma estratégica e política de posicionar-se 
diante das populações indígena e não indígena, a escola Ywará Puruborá garante o acesso a ela como forma de luta pelos seus direitos.

Mário também considera que o trabalho com a cultura indígena se dá pelo ensino da língua materna: "Todo indígena tem que ter, se tiver oportunidade de estudar, estuda, né? Porque fortalece a cultura. E com a escola, com a língua materna aí fortalece muito a cultura do indígena. Até pra poder tá lutando pelos direitos, né?” (Entrevista Mário, 08/09/2014).

Assim, estudar a Língua Puruborá e saber sobre ela contribui para que as pessoas do povo sintam-se e afirmem-se como indígenas, reivindicando o reconhecimento de sua identidade. No contexto atual, afirmar-se como indígena garante alguns benefícios, o que fortalece a luta por esse reconhecimento. Por isso, o trabalho com a língua na escola, ao mesmo tempo que permite "resgatá-la" para que não se perca, está ligado à (re) construção da identidade desse povo, empoderando-o diante da lutas que são obrigados a travar.

As aulas de Língua Puruborá, denominadas pelos e pelas participantes como de língua materna, acontecem na escola e buscam envolver todos e todas as integrantes da comunidade e não somente as estudantes matriculadas. $\mathrm{O}$ ensino dessa Língua, por não estar atrelado a um processo de letramento, uma vez que ela não é usada nas práticas sociais do povo, faz com que ela seja tratada como um objeto de ensino escolar e não como um veículo de comunicação, assim como acontece em outras escolas indígenas. Ou seja, os e as estudantes recebem aulas DE Língua Puruborá, mas não são ensinados NA língua.

O professor Mário é o sabedor indígena e estuda a Língua Puruborá há pelo menos 15 anos. Ele nos informou que em 2012 a Língua Puruborá foi homenageada durante uma semana no Museu Paraense Emílio Goeldi, em Belém. A professora Gisele afirmou que Mário foi o que se interessou pela Língua Puruborá: "Estudava sozinho na casa dele. Ligava o som, o DVD lá ${ }^{5}$, pediu da mãe, os DVD e ele estudava sozinho. Ninguém mais teve esse interesse, né?” (Entrevista Gisele, 12/09/2014).

\footnotetext{
5 Segundo Gisele, os DVDs foram disponibilizados pela pesquisadora Ana Vilacy Galúcio.
} 
O professor Mário contou-nos como surgiu o seu interesse em estudar a Língua Puruborá:

Interesse assim... quando eu via que tinha alguma coisa escrita na língua do povo Puruborá eu falei: "Eu vou aprender isso aqui” e já entrei de... eu falei: "Pra mim isso aqui, eu quero aprender." Mas não com intenção de ser professor. Aí depois que surgiu a ideia de ter um professor. Daí, eu como tava mais adiantado, tô sendo professor. (Entrevista Mário, 08/09/2014).

Ao relatar "Eu vou aprender isso aqui", Mário indica uma das suas identificações, um dos elementos que ele valoriza e empreende esforço para aprender. Essa identificação e valorização possibilita que ele esteja professor e ele sonha, deseja ou objetiva ver toda a comunidade aprendendo e falando nessa língua, que ela tenha correspondência com a prática social ao afirmar que "[...] eu queria um dia chegar pra ver todo mundo assim, chegar numa casa e ver todo mundo tá ensinando seu filho [...].” (Entrevista Mário, 08/09/2014).

O professor Mário utiliza como recursos materiais os trabalhos desenvolvidos por diferentes pesquisadores e pesquisadoras, entre eles, os das linguistas Ruth Maria Fonini Monserrat e Ana Vilacy Galúcio, por meio dos quais foi possível obter algumas listas de palavras na língua materna, bem como o vocabulário ilustrado - animais na Língua Puruborá, publicado em 2013 (Figura 1).

Figura 1- Capa do vocabulário ilustrado - animais na Língua Puruborá

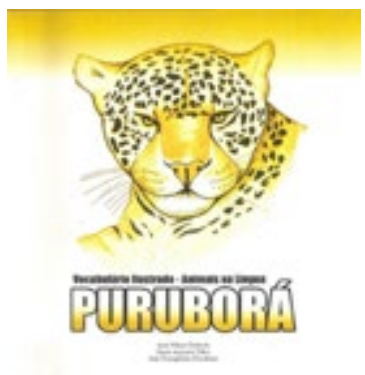

Fonte: Acervo pessoal da pesquisadora principal (escaneado). 
De acordo com Neves (2009), um dos desafios na construção da escola indígena intercultural é o limitado material didático diferenciado a que professores e estudantes têm acesso. Esta autora destaca que a falta de estudos descritivos e analíticos das línguas maternas de algumas etnias "[...] provoca impactos negativos na prática pedagógica no que se refere ao material didático diferenciado, inexistente ou insuficiente, que por sua vez leva as comunidades e seus docentes a escolherem a língua portuguesa para a alfabetização nas aldeias [...].”(NEVES, 2009, p. 205).

O vocabulário ilustrado - animais na Língua Puruborá, para o professor Mário, é representativo:

Ah! Aquilo ali é a história, né? Como eu tava falando, aquilo quando eu comecei foi só as vogal e umas palavrinhas. Esse livro veio chegar aí o ano passado pra gente, não, é o ano trasado chegou pra gente. Aí já veio já contemplando. Que eu comecei eu tinha pouca coisa. Tinha um livrinho fininho, alguma coisa só. Aí eu falei: "vou começar com isso aqui" e começamos, né? Mas isso aí já é fruto de muito trabalho, um trabalho com os outros mais velhos. [...] Assim, eu tenho assim, participação. Porque quando ela ${ }^{6}$ veio fazer o trabalho eu já era o professor, né? Ela veio passou uma semana aí, fomos fazer um trabalho de aula, plano de aula, assim, como funcionava. (Entrevista Mário, 08/09/2014).

Mário afirmou que no começo trabalha mais o vocabulário e as palavras, mas "Depois com os mais avançados eu já vou fazendo umas histórias, já vou fazendo umas frases." (Entrevista Mário, 08/09/2014). Segundo o professor Mário, todas as e os estudantes estão no $1^{\circ}$ ano na Língua Materna, e o trabalho envolvendo crianças e adultos não atrapalha. Percebemos que Mário e as outras pessoas adultas que participam da aula de Língua Puruborá aparentam ter paciência com as crianças e suas "agitações”, especialmente, com Katiely, que apresenta dificuldades na leitura das palavras em Língua Puruborá. Em um momento durante a observação em sala de aula, Mariana afirmou que Maria Paula lia melhor que Katiely as

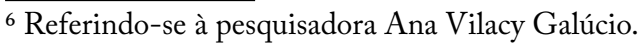


palavras na Língua Puruborá, e Marcela comentou: "Acho que é porque ela tem vergonha. Já falei para ela não ter vergonha, nós estamos aprendendo. Elas sabem igual a gente. Estamos aprendendo. Somos todos alunos." (DIÁRIO DE CAMPO, 11/02/2015).

Ao afirmar que "Estamos aprendendo", Marcela remete ao processo construtivo em que a Língua Puruborá se encontra. Nesse sentido, Dulce, ex-estudante e mãe da estudante indígena Mariana, ao afirmar a importância do trabalho com a língua, relatou:

$\mathrm{E}$ a gente não pode exigir muito porque está todo mundo, precisando mesmo. Que até o professor, ele dá aula e tudo, mas ele não aprendeu, ele não sabe muita coisa assim, de criança. Tá começando agora também né? Então a gente não pode exigir, essas coisas, muita coisa dele, porque ele tá aprendendo também, né? Mas eu acho que é muito importante, tanto pras crianças, quanto pra ele, pro professor, pro grupo, pra nós, pra todo mundo. Acho que é bom demais! (Entrevista Dulce, 02/09/2014).

O trabalho com o vocabulário ilustrado baseia-se na memorização da grafia, do significado das palavras e das frases que o livro contém e também de seu som. As cenas 1 e 2 demonstram como esse trabalho estava sendo realizado durante o tempo em que permanecemos em campo.

Cena 1- O trabalho com o vocabulário ilustrado - animais na Língua Puruborá (Situação 1). Cada estudante chegou e pegou com Mário um livro com vocabulário ilustrado de animais na Língua Puruborá. Cada uma foi para sua carteira ler as páginas correspondentes às letras que estão estudando: Rafaela e Mariana estão estudando a letra K. Katiely está estudando a letra B. Mário chamou Maria Paula para ler algumas palavras do caderno dela e orientou que ela copiasse aquelas palavras nas linhas deixadas por ele abaixo... Depois de uns 15 minutos que Rafaela, Mariana e Katiely estavam fazendo leitura no livro de língua materna, Mário pegou os livros e deu uma folha sulfite em branco para elas escreverem as palavras que lembrassem da letra que estavam estudando. (DIÁRIO DE CAMPO, 18/08/2014). 
Cena 2- O trabalho com o vocabulário ilustrado - animais na Língua Puruborá (Situação 2). Às $15 \mathrm{~h} 59 \mathrm{~m}$ Mário pediu para Mariana fechar o livro e disse para ela as palavras iniciadas com a letra $\mathrm{K}$ do livro da língua materna em Língua Portuguesa e ela respondeu na Língua $\mathrm{Pu}-$ ruborá. Mariana errou apenas duas palavras. Após perguntar todas as palavras para Mariana, Mário pediu para Katiely fechar o livro e disse para ela as palavras iniciadas com a letra B do livro da língua materna em Língua Portuguesa para ela responder na Língua Puruborá. Katiely apresentou muita dificuldade, por isso, Mário disse as palavras em Língua Puruborá para ela dizer o que significava em Língua Portuguesa. Katiely errou algumas palavras, mas apresentou menor dificuldade. (DIÁRIO DE CAMPO, 22/08/2014).

Outra atividade bastante trabalhada por Mário é o ditado. Antes de realizá-lo, ele trabalha algumas palavras na Língua Puruborá com uma letra específica, ou seja, copia as palavras no quadro, lê todas elas, solicita uma leitura individual de cada estudante (em voz alta), posteriormente, uma leitura coletiva com todos e todas presentes (em voz alta) e então pede que fechem os cadernos, entrega uma folha sulfite para cada estudante, orienta para que coloquem o nome e a data da atividade e inicia o ditado. Quando finaliza o ditado das palavras na Língua Puruborá, Mário solicita as folhas para corrigir as grafias, devolve para as e os estudantes olharem as palavras que estão grafadas erroneamente e devolver para ele, pois guarda todas as atividades realizadas pelas e pelos estudantes em pastas.

Nessas atividades de ditado, Mário consegue trabalhar a memorização, a atenção, a percepção e a grafia das palavras. Por meio da observação participante, percebemos que esse tipo de atividade pode contribuir para os processos de ensino e de aprendizagem, no entanto, a repetição causa o desinteresse das estudantes crianças. Além disso, a atividade torna-se demorada, pois há uma pausa prolongada entre uma palavra e outra e, nesse intervalo, as crianças ficam ociosas, o que causa cochichos e brincadeiras durante sua aula e traz incômodo para o professor.

Mário encontra algumas dificuldades no domínio da Língua Portuguesa, as quais se refletem no ensino da Língua Puruborá. Essa limitação 
do professor é reconhecida por Valdinei que a justifica por Mário estar concluindo o ensino fundamental. Informou-nos que disponibilizará uma gramática para Mário estudar e não o fez ainda porque não havia conseguido um bom livro. (DIÁRIO DE CAMPO, 01/09/2014).

Mesmo diante das limitações do vocabulário da Língua Puruborá dominado pelo professor, pelos e pelas estudantes, Mário trabalha com produção de textos, como podemos observar na cena abaixo.

Cena 3-Atividade de produção de texto realizada pelo professor Mário Mário fez o encaminhamento inicial: iríamos fazer uma história com desenho nesse dia. A história e o desenho poderiam ser do que gostamos de fazer, do que não gostamos, de animal, da nossa família, sobre qualquer coisa. Ele entregou uma folha sulfite para Mariana, Katiely e para mim. ${ }^{7}$. Mário escreveu algumas palavras na Língua Puruborá para Maria Paula ir copiando, enquanto Mariana, Katiely e eu desenhávamos e escrevíamos nossas histórias. Mário ficou sentado na sua mesa, folheando, vendo e lendo algumas palavras na Língua Puruborá registradas em um dos seus cadernos. Mariana perguntou: "Professor tem elefante em nosso livro?" Mário respondeu: "Não, mas não tem problema, a gente coloca em Português as palavras que não tiver."

[...] Mário perguntou se eu tinha terminado o meu desenho. Respondi que sim e ele pediu para ver, foi até sua mesa e começou a escrever minha história na Língua Puruborá. Enquanto Mário estava escrevendo minha história em Língua Puruborá, ele leu: "As nuvens tão lindas" e disse: "Nuvens eu não sei." Mencionou que iria colocar em Língua Portuguesa o que ele não sabia. (DIÁRIO DE CAMPO, 20/08/2014).

As afirmações de Neves (2009, p. 234) sobre os usos da escrita entre os povos indígenas pesquisados por ela também se aplicam ao povo Puruborá, para quem a escrita, além de representar a resistência e o protagonismo dos e das indígenas, não se aplica apenas a questões imediatas, como, por exemplo, a elaboração de uma lista de compras, “[...] mas se inscreve como objeto cultural,

${ }^{7}$ Nesse dia, Mariana se sentou próxima a mim, uma carteira na minha frente. 
que em uma linguagem poética narra acontecimentos e história do povo, como ampliação de um recurso de memória [...].” Para a autora, os povos indígenas, ao apoderarem-se da cultura escrita, reinventaram essa prática social que anteriormente era colonizadora e utilizada para fins integracionistas e, atualmente, a ressignificaram, utilizando-se dela para fins interculturais.

Como citado, mesmo diante das limitações pedagógicas e do conhecimento que o professor Mário apresenta, os e as participantes da presente pesquisa veem a aula de Língua Puruborá como de extrema importância. Assim, de acordo com Helena, é importante o trabalho com a língua “[...] porque minha mãe nunca... minha mãe não sabe falar. E ela também nunca passou isso pra nós. E agora a gente tá tendo a oportunidade de um professor passar pra nós. É bom que a gente aprende e passa pros nossos filhos.” (Entrevista Helena, 11/09/2014).

Embora para o povo Puruborá a língua seja um elemento importante da afirmação de sua identidade, denominando-a de língua materna, para este e para outros povos indígenas a língua materna é a Língua Portuguesa, e coube à escola fornecer o primeiro contato com a língua tradicional, ocupando por isso a posição de segunda língua e, em alguns casos, o tratamento de língua estrangeira.

Para Marcela, a importância da língua pode ser comparada à importância do território: "Ah, porque a gente precisa saber da nossa língua, porque um índio sem a sua língua materna, eu acredito que é um índio... É mesmo que não ter a sua terra, né?” (Entrevista Marcela, 08/09/2014). Esta afirmativa resume a importância atribuída à língua pelo povo da aldeia Aperoi. E esta valorização parece justificar a centralidade que é dada ao seu ensino, como a mais importante atividade cultural na reafirmação da identidade desse povo.

Nas entrevistas individuais com as estudantes Katiely, Maria Paula e Mariana, elas relataram que gostam das aulas de Língua Puruborá. Já a estudante Rafaela disse que gosta um pouco e destacou que gosta de ler, desenhar e fazer histórias nessas aulas. Deivid também concordou com Valdinei e Mário sobre a questão do trabalho com a cultura indígena na escola, relatando que: 
Rapaz, aqui na nossa escola nós tamo fazendo, que é sobre a língua, né? Isso daí é o primeiro passo do que foi feito. No momento eles só tão trabalhando a língua materna, porque não tem outro pra trabalhar artesanato, não tem uma criança homem pra gente trabalhar modo de como se flechar, fazer flecha. Só que a cultura tá sendo trabalhada que é a própria língua, né? (Entrevista Deivid, 11/09/2014).

Segundo Gisele, a cultura indígena é "um pouco" trabalhada na escola, no entanto,

Deveria ser mais, se a gente tivesse mais conhecimento. Porque [...] o que eu pouco sei foi por causa das pesquisas que eu fiz, o que eu pouco sei foi porque a vó ${ }^{8}$ me passou. Mas assim aquela cultura tradicional mesmo, igual é das outras etnias, a gente não é. [...] Mas assim, tipo pinturas, a gente já fez esse tipo de trabalho na escola, a gente já trabalhou um pouco da história, foi envolvido todo mundo, não foi só com eles. E a gente não trabalhou mais com os pequeninhos, porque assim, cultura assim sobre língua, pintura, mito a gente conversa, mas não trabalha muito em si. Porque eu trabalho mais com eles conteúdos não indígenas. É o que eu mais trabalho com os meus pequenos. [...] A gente não trabalha, tipo, cestaria, não trabalha na escola, porque eu também não sei e nem uma das mães das meninas também sabe. Eu acho que a gente deveria saber mais, pra poder trabalhar mais. Mas infelizmente pra gente fica mais difícil. A gente não pode deixar morrer aquilo que a gente já tem. Isso daí a gente não deixa. Mas assim, cestaria, trançados, como caçar, pescar, que é muito bonito lá no papel, mas que nas escolas indígenas, porque eu converso e eu tenho bastante amigos que são professores, não é trabalhado nem na nossa escola e nem em escola nenhuma. Eu não vejo que tem esse trabalho em si, de cultura. Tá muito bonito lá no papel. "Ah, os trançados, não sei o que", mas não tem. Até hoje não tem nenhum projeto político de escola assim que eu vi, que eu convivi com as meninas, que eu vi que tem mesmo assim aquele... como que eles conseguiram colocar no papel e como eles conseguiram trazer pra escola. É igual a nossa. (Entrevista Gisele, 12/09/2014).

${ }_{8}^{8}$ Referindo-se a dona Emília, matriarca do povo. 
A falta de maiores conhecimento sobre sua cultura é consequência do fato de a maioria do povo - especialmente os e as jovens, os e as adolescentes e as crianças do povo - não ter vivido a educação indígena nas aldeias, ao contrário, ter nascido, convivido e ter sido alfabetizada/escolarizada em contextos não indígenas.

Apesar de Deivid haver relatado que "não tem outro pra trabalhar artesanato", constatamos que a cacique Hozana possui essa prática, fazendo cocares, brincos, colares, pulseiras, palitos para cabelo, utilizando como matéria prima sementes diferentes, penas de aves diversas, entre outros, inclusive expõe em eventos de artesanato, vendendo-os e contribuindo na sua renda familiar. Entendemos que, nesse caso, seria possível e interessante para os e as estudantes a articulação entre esta prática cultivada pela Cacique e o trabalho com a cultura indígena no cotidiano da escola.

Sobre a participação "dos mais vividos”, Gisele afirmou que não é possível, "Porque o tio Paulo não tem como, porque ele vive doente. E se ele vem pra cá e tem algum ataque? $\mathrm{E}$ a vovó faleceu. $\mathrm{E}$ os outros mais velhos moram em Guajará." (Entrevista Gisele, 12/09/2014).

Entretanto, Gisele, juntamente com os professores Deivid e Mário, fazem esse trabalho de forma inversa. Em vez de os mais velhos virem até a escola, eles vão até os mais velhos, com o intuito de ter mais conhecimento sobre as práticas culturais do povo Puruborá e socializá-las com a comunidade. Nesse sentido, a escola é fundamental para (re)construção da identidade do povo, especialmente como espaço de socialização dessas informações, como os professores vêm fazendo. Porém, parece que esse processo não tem sido percebido pelos professores e pela professora, pois embora os e as participantes afirmem que o trabalho com a cultura indígena se dá por meio das aulas de Língua Puruborá, percebemos que esse trabalho também acontece no decorrer da elaboração e execução de projetos realizados pela professora Gisele, que por vezes contou com a ajuda dos professores Mário e Deivid. Ocorre que boa parte desse trabalho visava cumprir as atividades obrigatórias do curso de Licenciatura em Educação Básica Intercultural da UNIR, que Gisele concluiu em 2014, e não foi uma concepção ou criação da equipe de professores da escola. 
As condições próprias da história desse povo, cujas pessoas viveram em contextos não indígenas, com pouca convivência com os anciões e as anciãs do povo, parecem colocar para a escola uma tarefa muito específica: recolher e disseminar a cultura do povo, antes que ela se perca. Porém, esse trabalho não parece ser desenvolvido de forma consciente pelos professores e pela professora, exceto em relação ao ensino da Língua Puruborá. Assim, o ensino da língua assume a centralidade quando se trata de falar da cultura do povo, e outras práticas e histórias se fazem presentes no espaço escolar apenas em momentos específicos, não se configurando como um processo próprio de construção da escolarização específica desse povo.

A análise da organização e funcionamento do cotidiano da escola, bem como os diálogos estabelecidos com os profissionais que nela atuam, evidencia uma cisão entre o trabalho com os conteúdos curriculares e o trabalho com a cultura indígena. A cultura indígena, entendida como o trabalho com a Língua Puruborá, é considerada de responsabilidade do professor Mário, já os conteúdos não indígenas são atribuição da professora Gisele, que dedica a maior parte do tempo a esse trabalho, embora tenha desenvolvido projetos relacionados às práticas culturais tradicionais do povo Puruborá em momentos específicos.

Durante o período do trabalho de campo, não presenciamos nenhum momento em que a professora Gisele tenha trabalhado a cultura indígena durante suas aulas. Tivemos acesso apenas às descrições orais e escritas de outras situações desenvolvidas por ela, em momentos e anos anteriores, e percebemos que, para a professora, trabalhar com a cultura indígena na escola se restringe a trabalhar com a Língua Puruborá, e esta é a tarefa do professor Mário. A ela cabem apenas esses trabalhos esporádicos.

Isso nos instigou a pensar nas razões pelas quais a professora construiu essa concepção e atuação e percebemos que ela é decorrente de várias questões, dentre as quais destacamos: sua história de vida, que transcorreu em contextos urbanos, privando-a da possibilidade de viver sua infância e juventude nas tradições de seu povo; sua história de escolarização, transcorrida em escolas não indígenas, e a formação para a docência no ensino superior voltada para uma área de atuação mais filosófica e política, com 
enfoque menos específico nos anos iniciais do ensino fundamental, além do fato de a formação continuada, a que ela está tendo acesso, transcorrer em programas voltados para a realidade de escolas não indígenas.

Assim podemos inferir que o trabalho com a cultura indígena, apenas por meio de projetos específicos, sem de fato inserir essas práticas no cotidiano de suas aulas, decorre também da forma como ela se apropriou dos conhecimentos teóricos e práticos que a universidade proporcionou.

Além disso, ao acreditar que a inclusão da cultura se dá pelo trabalho na Língua Puruborá, a professora Gisele parece não se sentir responsável por essa tarefa, já que esse é o papel do professor Mário, o que ocasiona uma cisão dentro da escola, influenciando sua organização na divisão de horário e atividades. Assim, embora as atividades pudessem ser feitas por meio do trabalho coletivo entre a professora e os professores, ela e eles as dividem e, assim, as estudantes também acabam por construir uma visão cindida do processo de aprendizagem escolar e cultural.

Conforme Gisele esclarece em seu Trabalho de Conclusão de Curso, a formação a que teve acesso no ensino superior estava voltada para a atuação em conteúdos mais amplos, voltados aos e às estudantes dos anos finais do ensino fundamental:

[...] O curso teve a duração de cinco anos, onde nos três primeiros fiz o ciclo de formação básica com atuação nos anos iniciais do ensino fundamental e os dois últimos anos finais fiz o ciclo de formação na área específica das Ciências da Sociedade Intercultural, que me habilita para lecionar as disciplinas de História, Geografia, Filosofia, Sociologia e Antropologia. (MONTANHA, 2014, p. 11).

Essa formação talvez não tenha oportunizado a discussão de práticas mais focadas nos anos iniciais. E isso, somado à formação continuada ocorrida em programas nos quais também não se discutia a realidade indígena, pode ter fortalecido uma prática em que a realidade indígena não tenha se enraizado.

Ao contrário de Gisele, Deivid frequentou um curso de formação (Projeto Açaí) voltado para a formação de professores para os anos iniciais 
do ensino fundamental, específico para a realidade indígena. $\mathrm{E}$ foi com ele que Gisele conseguiu desenvolver algumas atividades em que ocorreu a integração da cultura em suas aulas por meio da Língua Puruborá.

Um exemplo de atividades desse tipo foi relatado por Gisele em relação à prática de pintura corporal que se iniciou após a efetivação de uma pesquisa que ela e Deivid fizeram acerca dos mitos e da pintura tradicional. Ela mostrou algumas fotos do dia em que, juntamente com Deivid, ensinaram às estudantes como era o processo de pintura e pintaram seus rostos. (DIÁRIO DE CAMPO, 16/09/2014).

A professora Gisele afirmou que, ao pesquisar sobre essa prática cultural, ela trabalhou, juntamente com Deivid, com os interessados e as interessadas:

E aí quando a gente foi pra descobrir as pinturas, as histórias, não teve como o tio Paulo vim, então só foi eu lá. Eu e o Deivid. Mas a gente chegou aqui, trabalhou no projeto. Não ficou assim, sabe, só comigo. Não, as pinturas foi divulgada. Tanto que o Deivid hoje em dia pinta todo mundo aqui na comunidade e até pessoa que não é da comunidade o Deivid pinta. A gente repassou os traços tudinho. Não ficou só comigo e com o Deivid. (Entrevista Gisele, 12/09/2014).

Em outro momento, Gisele relatou que procederam da mesma forma em relação aos mitos, utilizando a escola para compartilhar esse conhecimento com a comunidade:

[...] Porque o do fogo a gente conversou, o da pintura a gente também já conversou, da origem da língua e da origem do povo. Tanto que esses dois outros mitos foram trabalhados na escola, eles foram ilustrados. Aí a gente já trabalhou também na escola, como que era as brincadeiras dos mais velhos, as crianças mesmo fizeram pesquisa, como que era as casas, como que eles se viam como povo, a gente fez todos esses projetos com a comunidade. Não foi uma coisa fechada, da gente, e nem foi só da escola. Foi aberto. A gente convidou todo mundo. Daí foi eu e o Mário que trabalhamos o projeto. (Entrevista Gisele, 12/09/2014). 
Além disso, a professora Gisele já utilizou a escola como lugar que possibilitou a reflexão sobre a história do povo Puruborá, suas práticas culturais e suas ausências, como foi possível perceber ao assistir alguns vídeos da execução do projeto "História Tradicional do Povo Puruborá: narrativas da escola indígena Ywará Puruborá”. Desenvolvido em 2012 por Gisele, com ajuda de Mário, esse trabalho contou com a participação dos e das estudantes da escola, dos moradores e das moradoras próximas (crianças e adultos), inclusive o da Cacique.

Por meio desse projeto, Gisele proporcionou ainda a reflexão sobre a imagem dos e das indígenas construída e sobre o papel que as escolas não indígenas e para índios(as) teve e têm na veiculação e transmissão dessa imagem, o que intensifica o preconceito e a discriminação existentes contra os e as indígenas, inclusive as e os "ressurgidos e ressurgidas", como é possível perceber na cena 4.

Cena 4- Reflexão sobre a imagem dos e das indígenas construída e que é veiculada e transmitida nos livros didáticos

Um primo de Gisele estava segurando um livro com imagens de indígenas na época do primeiro contato e os portugueses explorando os e as indígenas e Gisele estava explicando: " $E$ ensinaram nas escolas, na escola indígena, na escola não indígena, e aí quando a gente sai na rua e alguém pega e fala assim: 'Mas você não é índio', aonde vocês acham que eles aprendem que índio tem que ser daquele jeito lá? Aonde começa o preconceito contra os indígenas?”. Uma das participantes respondeu que era na escola. Gisele pediu para os e as participantes olharem as imagens do livro que o primo dela segurava na frente e perguntou se alguma vez eles e elas tinham se questionado sobre aquelas imagens. Uma das primas de Gisele disse que não. Gisele pediu para se atentarem nas imagens. Levou livros diferentes e pediu para os e as participantes mostrarem as imagens dos livros. Gisele pediu para olharem o que era ensinado nas escolas não indígenas, dizendo: "Quando eles falam de índio eles incluem todo mundo, tá. Eles não especifica não, esse é tal povo. Cada nação tem seu jeito de se ver, o jeito que eles pensa que são os povos indígenas. Oh, vocês conseguem se ver? A nossa moradia são é assim? O livro didático ensina a realidade indígena no Brasil?”. 
Os e as participantes disseram que não. Gisele confirmou que não e acrescentou: "É triste". "O livro didático lá mostra que o índio é nu, pintado, correndo de tanga e ainda coloca lá que o índio não trabalha tá. Ali pode ver que os índios estão só caçando, pescando. Isso é o que as criancinhas, isso é ensinado pra nós que somos indígenas e a gente sabe a realidade, imagina as criancinhas. Olha só de onde vem o preconceito". [...] Voltando a atividade de antes, por que será que o livro didático ensina que o índio tem que ser daquele jeito? Por que hoje em dia ele não mostra, não retrata o índio como ele é, não mostra a gente que está ressurgindo, não mostra que o índio está podendo ter acesso a tecnologia, que o índio só não anda pelado, pintado e enfeitado? Que hoje em dia os indígenas não anda só de canoa, anda de moto, anda de carro, né, quero que vocês comentem sobre isso, fale sobre isso. O que vocês acham? (Cena de um dos vídeos do projeto "História Tradicional do Povo Puruborá: narrativas da escola indígena Ywará Puruborá”, 2012).

As situações destacadas no projeto desenvolvido por Gisele nos remetem às afirmações de Maheirie (2002, p. 39), quando afirma que a constituição da identidade singular é realizada no coletivo e as identidades singular e coletiva são compreendidas em uma dimensão temporal, implicando relação com o passado, o presente e o futuro; em razão disso, essas identidades “[...] são construídas por oposições, conflitos e negociações, sendo constantemente inventada por estes sujeitos, em um processo aberto, nunca acabado." Para a autora (2002, p. 41):

A constituição da identidade tem a marca da ambigüidade, da síntese inacabada de contrários, daquilo que é individual e coletivo, daquilo que é próprio e alheio, daquilo que é igual e diferente, sendo semelhante a uma linha que aponta ora para um pólo, ora para outro. A utilização do conceito de identidade nos permite desvelar os indivíduos, grupos ou coletividades, localizá-los no tempo e no espaço, "identificando-os" como estes e não outros, mesmo em metamorfose. (Destaque no original).

Ciampa (2004) também entende que as identidades individuais se refletem umas nas outras; sendo assim, falar de identidade do indivíduo é falar de uma identidade do grupo a que ele e ela pertencem, das pessoas 
com as quais se relacionam, das características que os e as agrupam, dos valores e causas defendidas, das associações em torno de suas identificações e das necessidades comunitárias. E, por isso, a identidade do grupo (coletiva) também contribui na construção da identidade individual.

Embora esses trabalhos de "resgate" e socialização de práticas culturais ocorram em momentos específicos, a escola indígena Ywará Puruborá tem sido um lugar de revitalização e divulgação da cultura indígena Puruborá e de luta pelo respeito que lhe é devido. Percebemos que nessa realidade acontece o oposto do que ocorre em outras escolas indígenas pesquisadas por Abbonizio (2013), Batista (2005), Belz (2008) etc. Ou seja, naquelas escolas há uma luta para que as aprendizagens que circulam na prática social sejam incluídas no currículo da escola. Já a escola indígena Ywará Puruborá tem desempenhado o papel de revitalizar as práticas culturais que a comunidade não pratica mais, recolhendo-as junto às pessoas mais velhas da comunidade e divulgando-as para toda comunidade, especialmente o ensino sistemático da Língua Puruborá.

Nesse sentido, Neves (2009, p. 189) afirma: “[...] observamos que há explicitamente uma atribuição muito clara que se espera da escola, a de revitalização da língua indígena como se fosse possível assegurar este comportamento entre as quatro paredes da sala de aula, sem a fundamentação e a correspondência com a prática e o contexto social."

Entretanto, segundo o Referencial Curricular Nacional para as Escolas Indígenas (RCNEI - BRASIL, 1998), a tentativa de recuperação linguística é muito importante, especialmente em comunidades indígenas em que somente algumas pessoas idosas falam a língua indígena do povo, enquanto as crianças falam apenas a Língua Portuguesa: "Essas iniciativas de revitalização, mesmo que apenas parciais, devem ser incentivadas devido aos benefícios políticos e à melhoria da autoimagem que trazem, não apenas aos alunos, mas a toda a comunidade." (BRASIL, 1998, p. 120). No caso dos e das Puruborá, percebemos que o seu ensino e registro está ligado à revitalização da autoestima, da cultura e da identidade do povo, e, por isso, mesmo em outros lugares que não a escola, o Vocabulário ilustrado - animais na Língua Puruborá, que é um símbolo das aulas de língua, é motivo de orgulho. 


\section{Considerações finais}

Percebemos que a escola Ywará Puruborá tem sido um lugar de revitalização e divulgação da cultura indígena. Já o trabalho com outros elementos da cultura na referida escola acontece em situações específicas, pois a professora Gisele e os professores Mário e Deivid não experienciaram durante a infância a educação indígena do seu povo. Embora ela e eles acreditem e possuam respeito às práticas culturais, desenvolvendo projetos que visam revitalizar algumas delas (língua, pintura, mitos e outras), essas práticas se tornaram objetos de ensino, mas mesmo assim estão contribuindo para a (re)construção da identidade do povo Puruborá.

A especificidade da história desse povo faz com que o trabalho na escola Ywará Puruborá se dê no sentido inverso daquele que ocorre em outras escolas indígenas, pois, em vez de os mais velhos virem até a escola, a escola vai até os mais velhos, com o intuito de registrar os conhecimentos sobre as práticas culturais do povo Puruborá, socializando-o com a comunidade.

Nesse aspecto, o trabalho com a Língua Puruborá é um elemento assumido pelos sujeitos da comunidade como fundamental para a identidade desse povo. Entretanto, a escola Ywará Puruborá não é uma escola bilíngue, mas uma escola com aulas de Língua Puruborá, uma vez que essa língua se tornou um objeto de estudo e não um veículo de ensino, já que a escola possui aulas DE e não NA Língua Puruborá. Isso porque a língua materna desse povo é a Portuguesa, apesar de eles considerarem a Língua Puruborá como sua língua materna.

Acreditamos que todo o povo Puruborá precisa participar ativamente das lutas pela demarcação do território, pela revitalização da sua cultura e pela manutenção da escola, que, embora esteja em construção (material, técnica, administrativa, pedagógica, social e culturalmente), tem contribuído para a revitalização da identidade indígena do povo. Segundo Hozana, as pessoas que moram na aldeia são as que mais lutam para que os direitos do povo sejam garantidos e cumpridos, entre eles, os da educação, pois são os/as maiores beneficiados e beneficiadas na concretização desses 
direitos. Em um de nossos diálogos, Hozana reclamou que não são todas as pessoas do povo que lutam pelos seus direitos, o que fragiliza um pouco a luta pela demarcação do território e demais reivindicações.

Entretanto, esse também pode ser resultado da falta da demarcação da Terra Indígena Puruborá, pois, sem condições de permanecerem ao redor da aldeia, já que não há emprego para todos e todas, os e as indígenas se mudam para as cidades vizinhas ou outras cidades do estado em busca de melhores condições de sobrevivência, o que aponta para a importância vital da garantia de acesso aos territórios ancestrais aos povos que a eles têm direito.

\section{Referências}

ABBONIZIO, Aline Cristina de Oliveira. Educação escolar indígena como inovação educacional: a escola e as aspirações de futuro das comunidades. São Paulo, 2013, 192f. Tese (Doutorado em Educação)- Universidade de São Paulo, São Paulo, 2013.

AMORIM, Siloe Soares de. Índios ressurgidos: a construção da auto-imagem os tumbalala - Os Kalankó, os Karuazu, os Catókinn e os Koiupanká. Campinas, SP, 2003, 301f. Dissertação (Mestrado em Multimeios)- Universidade Estadual de Campinas, Campinas, SP, 2003.

AMORIM, Siloe Soares de. Os Kalankó, Karuazu, Kaoipanká e Katokinn: resistência e ressurgência indígena no Alto Sertão alagoano. Porto Alegre, 2010, 431f. Tese (Doutorado em Antropologia Social)- Universidade Federal do Rio Grande do Sul, Porto Alegre, 2010.

BATISTA, Teresinha Aparecida da Silva. A luta por uma escola indígena em Te'yikue, Caarapó/MS. Campo Grande, 2005, 156f. Dissertação (Mestrado em Educação)- Universidade Católica Dom Bosco, Campo Grande, 2005.

BELZ, Karina Cristiane. Educação escolar Kaingang: do discurso oficial às práticas efetivas. Florianópolis, 2008, 189f. Dissertação (Mestrado em Educação)- Universidade Federal de Santa Catarina, Florianópolis, 2008.

BOSI, Alfredo. Dialética da Colonização. 3.ed. São Paulo: Companhia das Letras, 1996.

BRASIL. Referencial curricular nacional para as escolas indígenas. Brasília: MEC/SEF, 1998.

CIAMPA, Antonio da Costa. Identidade. In: LANE, Silvia Tatiana Maurer; CODO, Wanderley (Org.). Psicologia Social: o homem em movimento. São Paulo: Brasiliense, 2004. p. 58-75. 
DANTAS, Sérgio Silva; CIAMPA, Antonio da Costa. Projeto de vida e identidade política: um caminho para a emancipação. Revista de Psicologia da UFC, v. 5, p. 138-152, 2014.

FREIRE, Paulo. Pedagogia da esperança: um reencontro com a Pedagogia do oprimido. 2.ed. Rio de Janeiro: Paz e Terra, 1993.

FREITAS, Déborah de Brito Albuquerque Pontes. Escola Makuxi: identidades em construção. Campinas, SP, 2003, 234f. Tese (Doutorado em Linguística Aplicada)- Universidade Estadual de Campinas, Instituto de Estudos da Linguagem, Campinas, SP, 2003.

MAHEIRIE, Kátia. Constituição do sujeito, subjetividade e identidade. Interações, São Paulo, v. 7, n. 13, p. 31-44, jan-jun, 2002, Universidade São Marcos.

MONSERRAT, Ruth Maria Fonini. Notícia sobre a Língua Puruborá. In: XVII Encontro da ANPOL, Gramado, RS, 2002.

MONTANHA, Gisele de Oliveira. Mitos do povo Puruborá. Ji-Paraná, RO, 2014, 37f. Monografia (Graduação em Licenciatura em Educação Básica Intercultural)- Fundação Universidade Federal de Rondônia, Ji-Paraná, RO, 2014.

NEVES, Josélia Gomes. Cultura Escrita em Contextos Indígenas. Araraquara, SP, 2009, 369f. Tese (Doutorado em Educação Escolar)- Universidade Estadual Paulista "Júlio de Mesquita Filho”. Faculdade de Ciências e Letras, Araraquara, SP, 2009.

SANTOS, Boaventura de Sousa. Modernidade, identidade e a cultura de fronteira. In: SANTOS, Boaventura de Sousa. Pela mão de Alice: o social e o político na pós-modernidade. 13.ed. São Paulo: Cortez, 2010. p. 135-157.

SAWAIA, Bader Burihan. Comunidade como Ética e Estética. Uma Reflexão Mediada pelo Conceito de Identidade. Psykhe, Santiago, Chile, v. 8, n. 1, p. 19-25, 1999. Disponível em: http://www.psykhe.cl/index.php/psykhe/article/view/384/364. Acesso em: 13 mar. 2015.

SAWAIA, Bader Burihan. Identidade - uma ideologia separatista? In: SAWAIA, Bader Burihan (Org.). As artimanhas da exclusão: análise psicossocial e ética da desigualdade social. 2.ed. Petrópolis, RJ: Vozes, 2001. p. 119-127. 


\title{
7. A CRIANÇA KAIOWÁ E O SEU TERRITÓRIO
}

\author{
Antonio Hillário Aguilera Urquiza (UFGD) \\ Sônia Rocha Lucas (Saberes/UFGD)
}

\section{Introdução}

No Brasil, segundo dados do IBGE (2010), dos mais de 190 milhões de pessoas, 817,9 mil foram declaradas indígenas, no quesito cor ou raça. No entanto, ao somarmos todos os que não se declaram nesse mesmo quesito, mas se autodeclaram indígenas e são contabilizados dentro das terras indígenas, esse número passa para 896,9 mil pessoas distribuídas em 305 diferentes etnias, com o registro de 274 línguas indígenas no país.

Ao analisarmos os povos indígenas quanto a sua residência em Terras Indígenas, o número segue para 517,383 mil (57,7\%) e 379,534 mil $(42,3 \%)$ vivendo fora delas, ou seja, quase a metade da população indígena brasileira está vivendo em áreas urbanas, fora das Terras Indígenas. Mato Grosso do Sul, com 77.025 indígenas, conta com a segunda maior população indígena no país e 79\% de sua população vivem em terras consideradas indígenas, especialmente as reservas. Em primeira análise, esse dado pode ser considerado animador, mas, ao considerar a atual situação fundiária no estado do Mato Grosso do Sul - cenário de intenso conflito fundiário entre os indígenas e os proprietários rurais - percebemos que a realidade polêmica e de extrema violência contra os povos indígenas é apenas um dos elementos dessa situação.

Segundo o relatório de Violência Contra os Povos Indígenas em Mato Grosso do Sul, publicado pelo Conselho Indigenista Missionário CIMI (2010, p. 16), "no ano de 2003 a 2010 houve no Mato Grosso do Sul 250 assassinatos de indígenas, enquanto no restante do Brasil, neste mesmo período, foram registrados 202”. No ano de 2014 foram 25 vítimas indígenas assassinadas, somente em Mato Grosso do Sul (CIMI, 2014. p.76). 
Esse quadro, apresentado nos últimos anos, coloca o Estado como o líder do ranking de violência contra os povos indígenas no país.

Apesar das garantias constitucionais, entre eles o Artigo 231 da Constituição Federal de 1988, que reconhece o direito dos povos indígenas a seus costumes, línguas, religiões e organização social distintas da sociedade nacional, salientamos, no entanto, a contínua violação de direitos humanos desses povos, sendo um dos principais indicadores o descaso com o direito à demarcação de suas terras tradicionais.

O estado de Mato Grosso do Sul tem sido um cenário em que os povos indígenas, especialmente os Kaiowá e Guarani, têm enfrentado a dura realidade de um constante conflito fundiário, o qual só é possível de ser compreendido através do processo histórico de ocupação dessa parte do território brasileiro. Tal processo histórico de expropriação territorial já foi abordado por vários autores ${ }^{1}$. Cabe a nós, aqui, no contexto deste trabalho, a intenção de trazer novos elementos para buscar reconstruir os principais marcos históricos referentes à população/comunidade do Pakurity, a partir de dados históricos e relatos, somados à narrativa do líder indígena dessa aldeia, o senhor Bonifácio Reginaldo Duarte, com os dados de campo de 2015 e 2016, realizados no contexto da pesquisa de mestrado (Pós-graduação em Antropologia da UFGD).

Bonifácio, da etnia Kaiowá, filho de Pacheco Duarte e Felícia Duarte, nasceu na Aldeia Pakurity e permaneceu nesse território tradicional até seus oitos anos de idade, quando, juntamente com sua mãe, foi forçado a deixar a área, para retornar anos depois. Casou-se uma única vez com Priscila de Souza, da etnia Guarani, filha de Daniel Souza e Santa Souza, em 1950, com cinco filhos e, atualmente, 18 netos. Assim como o líder Bonifácio, todos são nascidos na aldeia.

Figura 1 - Bonifácio Líder Indígena

${ }^{1}$ Schaden (1974), Brand (1997), Pereira (1999, 2004), Mura (2006), Barbosa da Silva (2007), entre outros. 


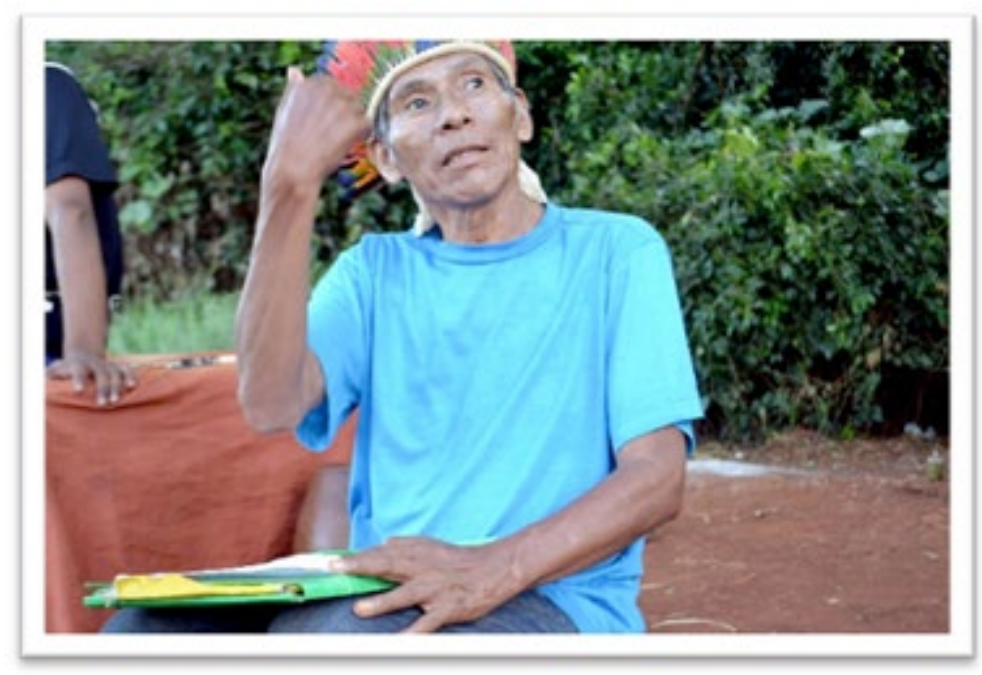

Fonte: Arquivos da pesquisa, 2016.

\section{História e relatos de Bonifácio Reginaldo Duarte acerca do território Pakurity}

Segundo Bonifácio, o tekoha Pakurity já era habitado pelos Kaiowá, antes mesmo da guerra do Paraguai (Guerra da Tríplice Aliança 18641870) e da chegada das primeiras frentes de ocupação agropastoril no sul do então Mato Grosso. Nesse contexto, e durante todo o período histórico da Primeira República (meados do século XX), notamos episódios que acarretaram grandes modificações no cenário nacional e que, mais tarde, culminariam na atual situação de confinamento dos povos indígenas (BRAND, $1993,1997)^{2}$ e situações que resultaram no esbulho de seus tekoha ${ }^{3}$.

Segundo Chamorro (2015, p.105), a primeira e a última fase da guerra que envolveu o Brasil, Argentina e o Uruguai, de um lado, e o Para-

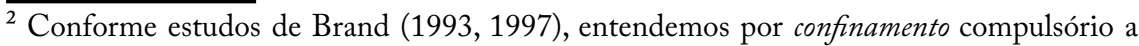
transferência sistemática e forçada da população das diversas aldeias Kaiowá e Guarani tradicionais para dentro das oito Reservas demarcadas pelo governo entre 1915 e 1928.

${ }^{3}$ Lugar físico e espiritual - terra, mato, campo, águas, animais, plantas, remédios etc. onde se realiza o teko, o "modo de ser", o estado de vida guarani. Engloba a efetivação de relações sociais de grupos macro familiares que vivem e se relacionam em um espaço físico determinado (conforme CAVALCANTE, 2013; e http://pib.socioambiental.org/pt/povo/ guarani-nandeva/1298. Acesso no dia 22 nov.2013).
} 
guai, de outro, ocorreu “em pleno território paĩ-tavyterã e kaiowá”. A autora ainda afirma que "A ocupação desse território por tropas paraguaias e brasileiras significou uma drástica interferência na região, a qual já tivera início com a presença dos viajantes demarcadores a partir de meados do século XVIII" e declara que "para as comunidades falantes de guarani, a guerra intensificou a política civilizadora iniciada anos antes e o povoamento da região de fronteira com o Paraguai por não indígenas” (2015, p. 111).

Após a Guerra do Paraguai, instala-se, no sul do então Mato Grosso, a Companhia Mate Laranjeira (1870) que, em 1877, deu início à exploração da erva-mate, mas em território Paraguaio. A empresa, sediada em Concepção, enquanto aguardava uma concessão do governo brasileiro para instalar-se no Brasil (CHAMORRO, 2015, p.112), tanto durante a permanência no Paraguai como no Brasil, usou intensamente a mão de obra do povo guarani para a extração da erva, o que foi um forte fator de impacto no processo das relações interétnicas (cf. FERREIRA, 2007).

Quanto à concessão da Companhia Mate Laranjeira no Brasil, Correa Filho apresenta que:

Quando o Barão de Maracaju se tornou presidente da província de Mato Grosso, Laranjeira recorreu à sua proteção. Foi por intermédio dele que conseguiu o decreto imperial no 8799 , de 9 de dezembro de 1882, que o tornou o primeiro concessionário legal para colher erva-mate nos terrenos devolutos existentes nos limites da Província de Mato Grosso com a República do Paraguai, "entre os Rio Verde e Amambai, e pela linha que desses pontos for levada para o interior" (CORREA FILHO, 1925. p. 22). Por ocasião da prorrogação do monopólio em 1894 por mais 16 anos, a terra arrendada à Companhia estendia-se das cabeceiras do Ribeirão das Onças, na serra do Amambai, ao Ribeirão São João, aos Rios Dourados, Brilhante, Ivinhema e Paraná, até a serra de Maracaju e "pela crista de ambas as serras até as referidas cabeceiras das Onças" (CORREA FILHO, 1925, p.30; apud CHAMORRO, 2015, p. 112, destaques do autor). 
Em tudo isso, podemos notar que a Companhia Mate Laranjeira teve grande influência na ocupação do território do sudoeste brasileiro e, em 1916, consegue, mais uma vez, através da Lei 725 de 24 de setembro de 1915, renovar o arrendamento de 1.440 .000 hectares, porém, a partir desta data, perdeu o monopólio. Correa Filho, citado por Chamorro, explica:

Essa mesma lei em seu artigo terceiro liberava a venda pelo Estado de até dois lotes de 3.600 hectares a terceiros, inclusive aos posseiros, no prazo de dois anos a partir de julho de 1916, preferencialmente aos que já ocupavam terras de pastagens ou lavouras dentro da área arrendada à companhia (CORREA FILHO, 1925, p. 30; apud CHAMORRO, 2015, p. 113).

A Grande Guerra e a Companhia Mate Laranjeira foram fatos preponderantes para a transformação do cenário territorial do Estado, mas, a esses fatos, não podemos deixar de somar as ações da criação da Colônia Agrícola Nacional de Dourados (CAND; através do Decreto Lei $\mathrm{n}^{\circ}$ 5.941/1943) que, juntos, trouxeram para o Estado muitos colonos com a finalidade de povoar o território (colonização) do sul de Mato Grosso. Como bem sabemos, esses territórios estavam ocupados por povos indígenas, especialmente os Kaiowá e Guarani.

O espírito nacionalista do Estado Novo motivou a Marcha para o Oeste, durante a qual foram assentadas famílias agricultoras procedentes de outras regiões do Brasil sobre terras geralmente ocupadas por indígenas. Em termos geopolíticos, o espírito nacionalista era sinônimo de ocupação efetiva das fronteiras e de substituição da migração estrangeira - entenda-se na região: argentina e paraguaia - por colonos nacionais. Iniciava-se aqui a fase de enfrentamento direto entre indígenas e não indígenas (CHAMORRO, 2015, p. 191).

Constatamos, assim, que foi o próprio Estado o indutor dessa política de ocupação territorial, à revelia da presença maciça de indígenas na região. Para Brand, a CAND interferiu de forma significativa nesse cenário da perda das terras indígenas. Ele diz: 
A implantação da Colônonia em área de aldeias Kaiowá marcou o início de uma longa e difícil luta dos índios pela manutenção e recuperação de nossas terras. Negávamos em deixar as terras, que foram vendidas pelo governo a colonos. Estes, por sua vez, buscavam constantemente obter a expulsão dos índios, através de ações na justiça, ou através de meios mais escursos (BRAND, 1997, p.78).

Assim feito, abriu-se espaço para a concessão de títulos públicos a particulares, com o intuito de ocuparem os "espaços vazios", chamados de "terras devolutas", em nome do desenvolvimento nacional. Bem sabemos que esses espaços não eram propriamente "vazios", mas de uso e permanência dos indígenas. E, para Brand (1997, p. 85), "o problema das terras indígenas, usurpadas pela Colônia Agrícola Nacional de Dourados, a partir de 1943, permanece sem solução até a presente data”. Apenas a comunidade de Panambi, no Município de Douradina, conseguiu reaver parte do seu território tradicional, no início do século XXI.

Anterior à CAND, mas já com a intenção de liberar as terras para os novos colonos, nos anos de 1915 a 1928 foram criadas as oito reservas ${ }^{4}$ indígenas no sul do estado para abrigar as comunidades Kaiowá e Guarani. Cabe ressaltar que em nenhum momento foi considerada - ou respeitada - a diferença étnica de seus grupos e o direito inalienável a seus territórios tradicionais, situação que acarretou e ainda acarreta um grande conflito interno e desconforto entre as parentelas. Diante desse fato, ou seja, com a criação dessas reservas, a situação do território e a própria cosmologia dos Kaiowá e Guarani ficaram comprometidas, tendo em vista a importância da terra para o modo de viver em seus tekoha. Tal importância é destacada por Aguilera Urquiza:

[...] esta terra torna-se fundamental para produção e reprodução da cultura de um povo, pois para eles, tudo que se relaciona com a estrutura social, ritual ou religiosa está intimamente relacionada ao território. A terra é, desta forma, um recurso sociocultural, mais que apenas um recurso da mãe natureza (2013, p. 64).

\footnotetext{
${ }^{4}$ As oito reservas são: Amambai, Dourados, Caarapó, Porto Lindo, Taquaperi, Sassoró, Limão Verde e Pirajuí - (Cavalcante, 2013, p. 84).
} 
A partir desse cenário, rapidamente descrito, o senhor Bonifácio ressalta as modificações que não somente sua comunidade, mas os indígenas do estado enfrentaram. Ele diz:

A Republica Brasileira criou a então denominado CAND - Colônia Agrícola Nacional de Dourados - que veio fazer um serviço para colonizar a região e com ela a ideia de fazer (instituir as reservas). $O$ próprio constituinte da República tiveram a ideia de fazer uma aldeia/reserva. Isso começou em 1916. E nesse mesmo ano as estratégias quanto aos indígenas foram sendo modificadas, principalmente com o fechamento da Matte Laranjeira. Nessa mesma época, em 1916, esse lugar onde estamos era cheio de indígenas Kaiowá e Guarani. Era bastante a população Kaiowá e Guarani, com sua maneira de viver, maneira de andar e falar. Viviam em uma vida de igualdade (teko joja). E assim continuou até 1924, em que se pensou com grande euforia (por parte dos governantes) em se arrumar uma aldeia, ou seja, um lugar para os indígenas. Encontrar uma solução para os indígenas (Entrevista, 2016).

Sendo assim, para o líder indígena Bonifácio, o marco fundamental da perda de seu tekoha ocorreu em 1924 (demarcação das reservas pelo $\mathrm{SPI})$, quando:

O governo decidiu arrumar um lugar reservado para nós, os indígenas e, assim, encontrar uma solução razoável frente a ocupação territorial do Estado na época. Enquanto essa estratégia se consolidava na região, nós vivenciávamos dois cenários antagônicos: o primeiro, que se concentrava nas medidas do governo quanto ao destino dos povos indígenas e, no outro, era a nossa permanecia com o nosso modo de viver em nosso tekoha, ou seja, em nossos territórios tradicionais (Entrevista, 2016).

Diante deste quadro histórico e no contexto de todas essas transformações, segundo Bonifácio,

O teko porã, ou seja, o modo de ser verdadeiro de um Guarani e Kaiowá, foi se modificando cada vez mais, pois o lugar em que vivíamos, o tekoha Pakurity, era cheio de indígenas e possuía uma população bem 
numerosa, tanto da etnia Kaiowá, como a dos Guarani. Nós podíamos viver, falar e andar livremente segundo o nosso costume e tradição. Havia, também, uma casa de reza e vivíamos, o dia a dia, na maneira tekojoja (viver entre iguais) em toda comunidade, mostrando a importância da terra para a comunidade (Bonifácio; Entrevista, 2016).

Em tudo isso, Bonifácio destaca que "enquanto o pensamento de se colocar os indígenas em reservas crescia e se desenvolvia, naquela mesma época havia muitos indígenas no tekoha do Pakurity. Tinha um número grande de pessoas, tinham a casa de reza e seu domínio próprio”. Com o "domínio próprio", entende-se aqui a autonomia e a liberdade dos povos indígenas, em específico, os da aldeia Pakurity.

Nas décadas seguintes, as ações do governo em agrupar todos os indígenas do estado nas respectivas reservas intensificaram-se a todo custo e, diante desse quadro, a maior indignação, segundo Bonifácio, foi, principalmente, "a ação de esbulho contra os povos indígenas que contou com a ajuda do, até então, SPI - Serviço de Proteção aos Índios, visto que esse órgão tinha como objetivo a proteção dos povos indígenas”.

Podemos ver nas palavras de Pereira que houve poucos esforços para se reservar terras para os povos indígenas. $\mathrm{O}$ autor diz:

Quando se pensou em reservar terras para os índios, o destino inicial desses espaços era, via de regra, abrigar a população kaiowá que já vivia nesses locais. Entretanto, logo acabou prevalecendo a intenção de reunir nesses espaços a população de um grande número de comunidades kaiowá dispersas pelo território (PEREIRA, 2006, p.72).

E continua o mesmo antropólogo:

A população kaiowá resistiu de diversas formas, procurando manter a posse das terras que ocupava. Entretanto, a maior parte das famílias das comunidades que tiveram suas terras expropriadas pelas frentes de ocupação agropecuária gradativamente cedeu às pressões dos fazendeiros e dos funcionários do SPI e se recolheu às áreas de acomodação (PEREIRA, 2006, p.72). 
Nesse contexto, inserimos aqui uma breve biografia do líder Bonifácio, até porque seu relato confunde-se com este período de perda dos territórios tradicionais. Em suas próprias palavras:

Em meio a tudo isso, em 1940 eu, Bonifácio Reginaldo Duarte, nasci no município de Dourados/MS em solo da Aldeia Pakurity e ainda na infância, por volta dos 8 anos de idade, meu pai Cacique Duarte faleceu, fato que se tornou em um grande motivo para unir e fortalecer ainda mais toda a comunidade da Aldeia Pakurity em defesa da posse de seu território. Nós criamos ainda mais força para continuar com nossa luta (Bonifácio; Entrevista, 2016).

Quando o senhor Bonifácio já estava mais crescido, conta que enfrentou a dura realidade da entrada e da presença dos colonizadores em seu território e, com eles, o empenho de dar maior movimento monetário para a região, através da criação de gado ou de outros negócios. Essa invasão chegou até o tekoha Pakurity. Em sua fala, Bonifácio afirma:

A aldeia era um lugar bom e espaçoso em que os colonos em viagens encontravam para fixarem suas tropas. Geralmente eles vinham do sentido Ponta Porã - Cuiabá. O dono de uma dessas tropas que passou pela região e permaneceu na terra da Aldeia Pakurity foi a família Torraca. A princípio a família Torraca trabalhava na Matte Laranjeira e com o fechamento da empresa eles passaram a negociar gado (Bonifácio; Entrevista, 2016).

Após a entrada dos colonos nas terras indígenas, era comum utilizar do trabalho dos próprios indígenas para a derrubada da mata e limpeza do terreno. O senhor Bonifácio, declara que "como não poderia ser diferente, com o passar do tempo eu me tornei empregado deles" (Entrevista, 2016).

Crespe acrescenta que "depois de realizado o trabalho de limpeza, os índios, na maioria das vezes, não eram mais tolerados e então eram expulsos” (2015, p. 231). Tal expulsão, para a autora, era:

[...] a expulsão do tekoha tendia a ser gradativa, na medida em que as matas eram derrubadas para a introdução das lavouras e pastos. 
Quando saíram de lá outros parentes já haviam saído e se esparramado por diversas áreas. Alguns foram para a reserva indígena de Dourados, onde Bonifácio foi com a mãe. Entretanto, segundo Bonifácio, algumas famílias conseguiram permanecer escondidos dentro da área até pouco tempo atrás (CRESPE, 2015, p.229).

Para Bonifácio, após a retirada da comunidade do território em que viviam, eles andaram transitoriamente em outros territórios indígenas e, por várias vezes, tentaram voltar ao seu tekoha, mas sempre foram expulsos pelos proprietários rurais. Ressalta que eles sempre retornavam ao território. Faziam caminhadas, a fim de coletar frutos e remédios, fazer pescas e, até mesmo, voltavam para trabalhar nas fazendas. Bonifácio afirma que ele mesmo continuou empregado da família Torraca e "cheguei a ver os próprios índios desse tekoha trabalhar por uma galinha, por um bezerro ou cavalo. Muitos trabalharam para o fazendeiro" (Entrevista, 2016).

Nesse período de perambulação dos indígenas e, em específico, do Bonifácio, ao redor do seu território tradicional, podemos mapear o seguinte trajeto:

Depois de isso ocorrer com a família de Bonifácio eles passam a perambular de um lado para o outro porque, segundo Bonifácio, não tinha onde morar: $E$ a gente começou, depois, não ter lugar para morar. Fui para Nova Alvorada do Sul e fiquei mais de vinte anos, vendendo arco e flecha, andando para lá e para cá. A ida para Nova Alvorada do Sul se deve a não acomodação na reserva e ao não desejo de permanecer nela, o que gerou uma perambulação forçada dessas famílias, segundo o que me disse Bonifácio. Depois dessa perambulação, ele se lembra de retornar ao tekoha produzido pelos jary’i: (CRESPE, 2015. p. 231).

Durante esse período, as crianças também têm um destaque:

A criançada não podia mais falar guarani, dançar, caçar, e começou por em risco nosso costume. É pra terminar, esse é o primeiro pensamento que nós tivemos. A partir disso eu disse não pra isso aí, e o espaço é muito pouco. Aí nós lembramos de voltar pro nosso tekoba. (Bonifácio, apud CRESPE, 2009, p. 65) 
E, como relatado por vários autores ${ }^{5}$ os indígenas Kaiowá e Guarani do tekoha Pakurity também não conseguiram viver livremente onde o estado os colocou, ou seja, nas reservas. "Não conseguimos viver, não da maneira do modo tradicional, ou seja, viver no tekojoja”, segundo Bonifácio (Entrevista, 2016).

A partir do final da década de 1970 e principalmente dos anos 1980 em diante é que se intensificam o movimento indígena e a mobilização política para obter do Estado o reconhecimento e a demarcação de parte do seu território tradicional como terras indígenas (CAVALCANTE, 2013, p. 24). Com o advento da Constituição Federal de 1988, a mobilização para a retomada do território tradicional ganha maior proporção no estado do Mato Grosso do Sul.

\section{0 território Pakurity}

A aldeia Pakurity está localizada junto a BR 463, a $20 \mathrm{~km}$ do perímetro urbano de Dourados, em sentido Ponta Porã/MS. Os Indígenas que vivem no tekoha Pakurity são, em sua maioria, da etnia Kaiowá; apenas alguns são Guarani (Ñandeva). No local encontramos aproximadamente 15 moradias indígenas (barracos de lona) espalhadas ao longo de uma mata ciliar e, segundo o senhor Bonifácio ${ }^{6}$, líder da comunidade, são aproximadamente 87 pessoas e 80 crianças, distribuídas em 10 famílias.

As famílias da comunidade Pakurity, como muitos outros grupos indígenas, vivenciaram o processo histórico de esbulho de seus territórios tradicionais e, após perambular por vários lugares, passaram a viver à margem da BR 463, entre a rodovia e a cerca da fazenda, enquanto não conseguiam retomar seu tekoha.

Conforme citado anteriormente, com o advento da Constituição Federal, fruto de muita luta de grupos e organizações indígenas e indigenistas, iniciaram em todo o estado as "retomadas", ou seja, tentativas

\footnotetext{
5 Podemos citar Brand (1998), Pereira (2006), Aguilera Urquiza (2013), entre outros.

${ }^{6}$ Bonifácio Reginaldo Duarte: Entrevista [22 jan. 2014]. Anotações em caderno de campo. Entrevista concedida no âmbito do projeto de iniciação científica (PIBC/CNPq), desenvolvido por Sônia Rocha Lucas, junto à Universidade Federal de Mato Grosso do Sul.
} 
de reocupar as áreas que consideram suas terras tradicionais. Sobre isso, comenta Pereira que se verificam

[...] iniciativas de vários líderes indígenas de tentarem reagrupar suas comunidades com o fim de reocupar parte dos territórios perdidos para a ocupação agropastoril.Tais tentativas são percebidas como necessárias para recuperar as condições necessárias à reprodução física e cultural de suas comunidades. Isto requer o empenho dos líderes no reagrupamento dos parentes e na atualização de formas de sociabilidade parental, tornando possível a atualização das comunidades políticas. Apresentar-se como comunidade política é o primeiro passo para novamente reivindicarem uma base territorial (2010, p. 118).

Atualmente, a aldeia Pakurity encontra-se em um pequeno fragmento do amplo território tradicional reivindicado, ou seja, em alguns poucos hectares, dos 15.500 já reivindicados. Mesmo vivendo em parte do seu tekoha, trata-se de uma comunidade em situação de acampamento, cercada de situações de conflitos e provisoriedade.

Atualmente, no Estado de Mato Grosso do Sul há mais de 40 acampamentos que estão, ou na beira da estrada, ou em pequenas parcelas de seu território tradicional (como é o caso do Pakurity), ou, ainda, tentando "retomar" seu tekoha. Tratar da atual situação da regulamentação e demarcação das terras desses acampamentos é assunto muito complexo e delicado, principalmente por se tratar de casos inseridos no contexto dos conflitos fundiários que ocorrem no sul do Estado. No caso do Pakurity não é diferente. No site da FUNAI e do Ministério Público, não consta nenhuma informação quanto a atual situação desse processo da aldeia Pakurity. Sabemos que, em 12 de novembro de 2007, foi assinado o Termo de Ação e Conduta (TAC) com a finalidade de constituir Grupos Técnicos (GT) com vistas à identificação e delimitação de 7 Áreas Indígenas. As Terras Indígenas estão divididas em grandes áreas que abrangem várias aldeias/tekohás. A aldeia Pakurity está inserida na Área Indígena Douradopegua. O GT foi constituído por especialistas, coordenado por um antropólogo, o qual deveria elaborar os relatórios de identificação e delimitação das Terras Indígenas. No caso do Pakurity, até o momento, o GT ainda não finalizou sua ação em todo esse processo. 
Sendo assim, sem o relatório de identificação e delimitação do território, a fonte de dados para a pesquisa utilizada neste trabalho, sobre quais os limites que abrange o território do Pakurity, volta-se para os relatos do líder indígena Bonifácio ${ }^{7}$. Ele afirma que conhece muito bem a área reivindicada como sendo o território de posse tradicional de seu povo. "Tenho gravado em minha cabeça, posso mostrar em todos os caminhos que usamos na nossa vida do dia a dia. Caminhos que fazem parte na nossa caça, pesca e contato com outros parentes" (Bonifácio. Entrevista, 2016).

Segundo ele, "o território vai da cerca próxima ao Yvyjumirim até o Manguruju e do Pirity ao Ajacareta". Essas marcações e outras mais específicas o Sr. Bonifácio desenhou em um papel (Figura 2), que abrange os 15.500 reivindicados pela comunidade. Segundo ele, "tal figura foi produzida pela comunidade para não permitir o esquecimento de toda a área que corresponde ao território tradicional do Pakurity”. Para Bonifácio, “a área proporcionava aos antigos a liberdade de viver e andar livremente em toda a sua extensão”.

Observando ainda a Figura 2, podemos destacar que o tekoha Pakurity envolve ambos os lados da BR 463. Do lado oposto, em que encontramos atualmente a comunidade, está a região do Pirity (n.2 na Figura 2). Recebe esse nome porque, segundo o Bonifácio, "os antigos saiam do rio Dourados e caminhavam até o Pirity para buscar uma espécie de semente que os mesmos utilizavam para colocar dentro do chocalho a fim de produzir o som". $\mathrm{Na}$ parte superior esquerda, há um cemitério, no qual está enterrado o seu pai, Pacheco Duarte, antigo Cacique (n.1 na Figura 2).

$\mathrm{Na}$ parte inferior direita, encontramos a localização da área da atual permanência dos indígenas do Pakurity (n.3 na Figura 2), devidamente sinalizado.

Ainda na Figura 2, podemos verificar, na parte inferior do canto esquerdo, a assinatura (n. 4 na Figura 2) do presidente da FUNAI, Mércio Pereira Gomes (2003 a 2007). Segundo o relato do Bonifácio, em uma

\footnotetext{
${ }_{7}^{7}$ Bonifácio Reginaldo Duarte: Entrevista [16 abril. 2016 ]. Dourados (acampamento Pakurity), 2016. Anotações em caderno de campo e filmagem. Entrevista concedida no âmbito do projeto de mestrado (Antropologia - UFGD).
} 
visita ao acampamento, Mércio pôde verificar a localização e permanência da comunidade na aldeia Pakurity e assinou o desenho, para comprovar a sua presença no local. O senhor Bonifácio afirma que "Mércio nos encontrou nesse mesmo local. Lugar onde fizemos a primeira retomada física e aqui permanecemos até hoje". De maneira incisiva, segundo o relato do líder indígena Bonifácio, a extensão da aldeia Pakurity abrange desde o rio Dourados até o local em que a comunidade se encontra atualmente, compreendendo os dois lados da BR463.

Figura 2 - Mapa Pakurity produzido pela comunidade

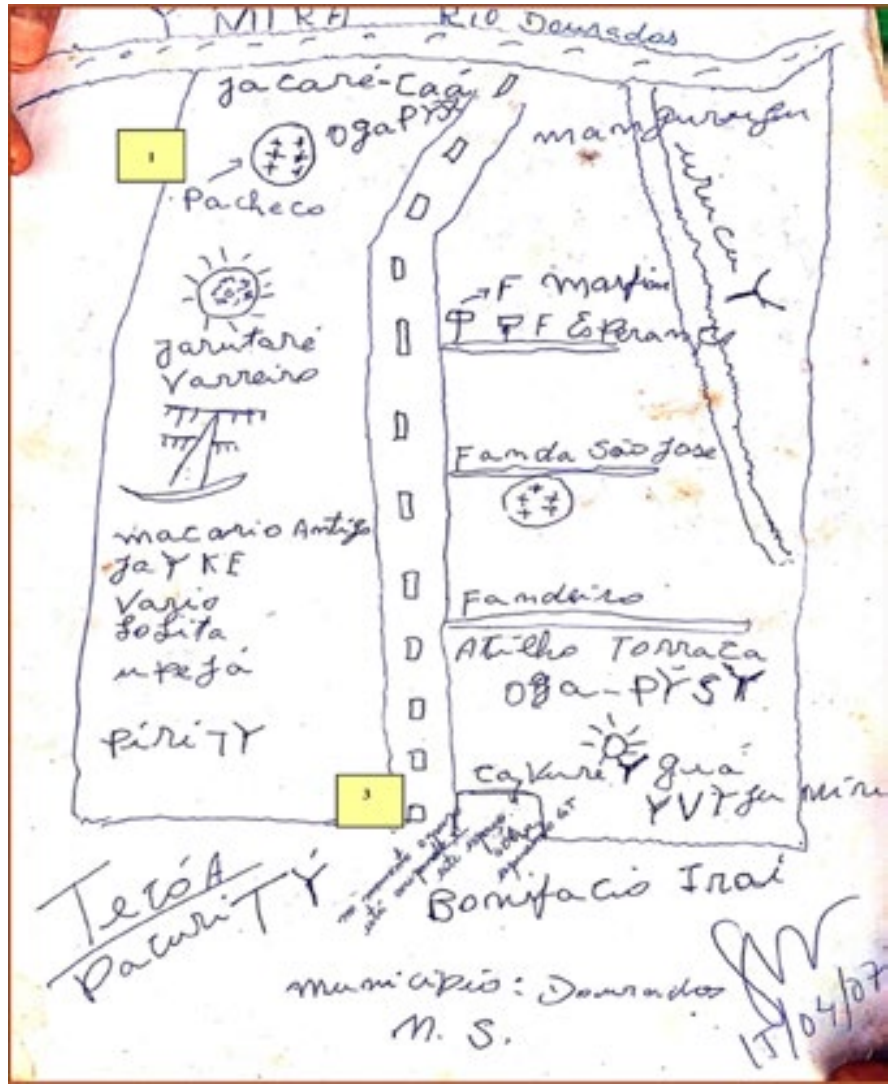

\section{LEGENDA:}

1. Cemitério onde foi enterrado o pai de Bonifácio o Cacique Duarte;

2. Região do Pirity

3. Local onde se encontra a comunidade indígena do Pakurity;

4. Assinatura do presidente da Funai Mércio Pereira Gomes. 


\section{A criança Kaiowá e o território}

No presente contexto, apresentado até o momento, cabe a nós perguntar: como vivem as crianças e como fazer para se ouvir a voz das crianças Kaiowá? Para aprofundar essa pergunta, iniciamos com a reflexão de Sarmento:

No entanto, o paradoxo maior da expressão "ouvir a voz das crianças" reside não apenas no facto de que ouvir não significa necessariamente escutar, mas no facto de que essa "voz" se exprime frequentemente no silêncio, encontra canais e meios de comunicação que se colocam fora da expressão verbal, sendo, aliás, frequentemente infrutíferos os esforços por configurar no interior das palavras infantis aquilo que é o sentido das vontades e das ideias das crianças. Mas essas ideias e vontades fazem-se "ouvir" nas múltiplas outras linguagens com que as crianças comunicam. Ouvir a voz é, assim, mais do que a expressão literal de um acto de auscultação verbal (que, alias, não deixa também de ser), uma metonímia que remete para um sentindo mais geral de comunicação dialógica com as crianças, colhendo as suas diversificadas formas de expressão (SARMENTO, 2011, p. 28, destaques do autor).

O autor acrescenta, ainda, que "o desenho infantil insere-se entre as mais importantes formas de expressão simbólica das crianças" (SARMENTO, 2011, p. 28). Dessa maneira, escolhemos a técnica de desenhos como forma de expressar a percepção das crianças indígenas da aldeia Pakurity em relação ao seu território.

No contexto do trabalho de campo desenvolvido na comunidade, foram dois os momentos em que trabalhamos com as crianças a técnica dos desenhos. O primeiro foi realizado com onze crianças de 6 a 15 anos, todas da aldeia Pakurity, produzindo no total 25 desenhos. Para a realização metodológica da técnica de desenho, reunimos as crianças em uma determinada área/barraco da aldeia, que até o momento era utilizada para reuniões e que atualmente foi transferida para outra parte. As crianças se acomodaram conforme lhes aprouve (Figura 3). 
Figura 3 - Crianças do Pakurity desenhando

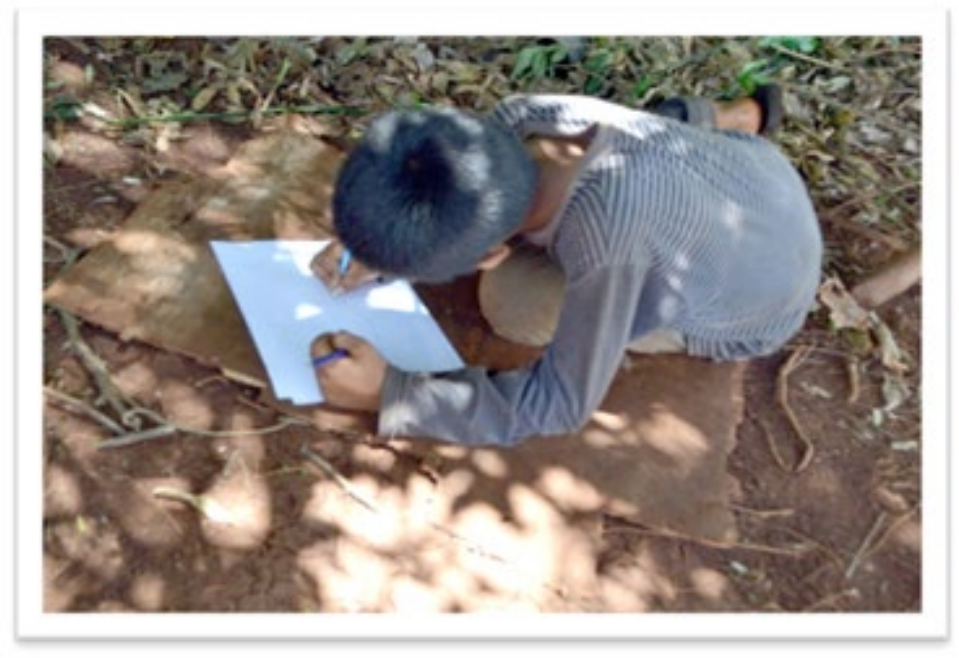

Fonte: Arquivos da pesquisa, 2014

Sentadas no chão, nos bancos ou em pneus abandonados e até mesmo deitadas, cada criança, após a orientação, fez o seu desenho durante um certo tempo. Cabe salientar que cada folha equivale a um desenho feito por uma criança indígena, pois houve a participação de alguns adultos, mas os desenhos produzidos por eles não foram considerados para o estudo em tela.

Após a atividade do desenho das crianças, continuamos entre elas na comunidade, visitando seus espaços de convivência, de recreação e de relações sociais. Para a análise ${ }^{8}$ destacamos nos desenhos elementos contidos em 6 grupos distribuídos nos seguintes temas: 1. Flora - Desenhos referentes à vida vegetal; 2 . Fauna - Temas referentes à vida animal; 3. Terra - Desenhos referentes à terra, ou relações com o ambiente; 4. Lagos - Temas referentes a lagos ou rios; 5. Temas Tradicionais - Desenhos

\footnotetext{
${ }^{8}$ A análise dos desenhos foi abordada originalmente no texto: LUCAS \& AGUILERA URQUIZA. TÔ AQUI... PARECE QUE TÔ RENASCENDO TUDO DE NOVO": experiências de campo sobre a retomada da terra e a retomada cultural dos acampamentos Pakurity e Laranjeira ñanderu. Revista Nanduty, Dourados - MS. Vol. 3, N. 3: Dossiê Educação Indígena - Miscelânea | janeiro a junho de 2015.
} 
referentes a objetos de uso tradicional da cultural Kaiowá e Guarani do Pakurity; e 6. Outros Temas - aqueles que não se apresentam na cultura Kaiowá e Guarani do Pakurity (elementos externos à sua cultura tradicional). Os desenhos, uma vez recolhidos, foram separados nas temáticas apresentadas para a análise.

Após análise dos desenhos, o resultado que obtivemos foi que os grupos 1. Flora e 2. Fauna aparecem em 17 dos 25 desenhos realizados pelas crianças. Eles contêm imagens como: árvores, plantas, flores e gramas (grupo 1), assim como pássaros, tatu, cobra, peixes, cachorro, cavalo, touro e onça (grupo 2).

O tema 3. Terra nos causou um impasse. Se levarmos em consideração apenas os desenhos que contêm imagem que delimita o espaço físico (chão) no desenho, como exemplo, montanhas, caminhos, estrada ou uma determinada região cercada, seriam 11 desenhos que contêm tais objetos. Mas, se o desenho fizesse alusão à possibilidade de uma representação do solo ou uso da terra, apenas 2 dos desenhos do total geral não se encaixariam nesse grupo, pois esses desenhos apresentam apenas objetos tradicionais (diadema indígena, arco, flecha e maracá). Nesse caso, seriam 23 desenhos com imagens no tema 3. Terra. Sendo assim, a maior expressão contida nos desenhos faz alusão a terra, fauna e flora. O que mudaria significativamente o resultado da análise.

Os desenhos referentes aos Grupo 4 (Lagos) e 6 (Outros Temas) foram apresentados em 5 desenhos. Elementos como casa tradicional, espécie de diadema indígena, arco, flecha, maracá, fogueira, cacique e um pajé estiveram presentes em 16 dos desenhos do Grupo 5, que se refere aos objetos pertencentes ao cotidiano da vida tradicional Kaiowá e Guarani - Pakurity.

Em suma, se considerarmos toda alusão à possibilidade de uma representação do solo ou uso da terra, o resultado seria o seguinte: $\mathrm{O}$ grupo Terra viria em primeiro lugar com 23 desenhos; seguido por Fauna e Flora (17 desenhos); Temas Tradicionais (16 desenhos) e Lagos juntamente com outros objetos, ambos representados em 5 desenhos. 
Para melhor exemplificar, escolhemos as figuras 4 e 5, com elementos classificados como Temas Tradicionais. A criança desenhou um cocar (jeguaká) confeccionado com penas, um arco e o maracá. Não cabe aqui discutir se tais objetos, assim como estão representados, são ou não utilizados pelos Kaiowá e Guarani, mas queremos trazer o significado de um objeto de uso tradicional representado por uma criança indígena através do desenho.

Figura 4 - Desenho classificado no Grupo Temas tradicionais

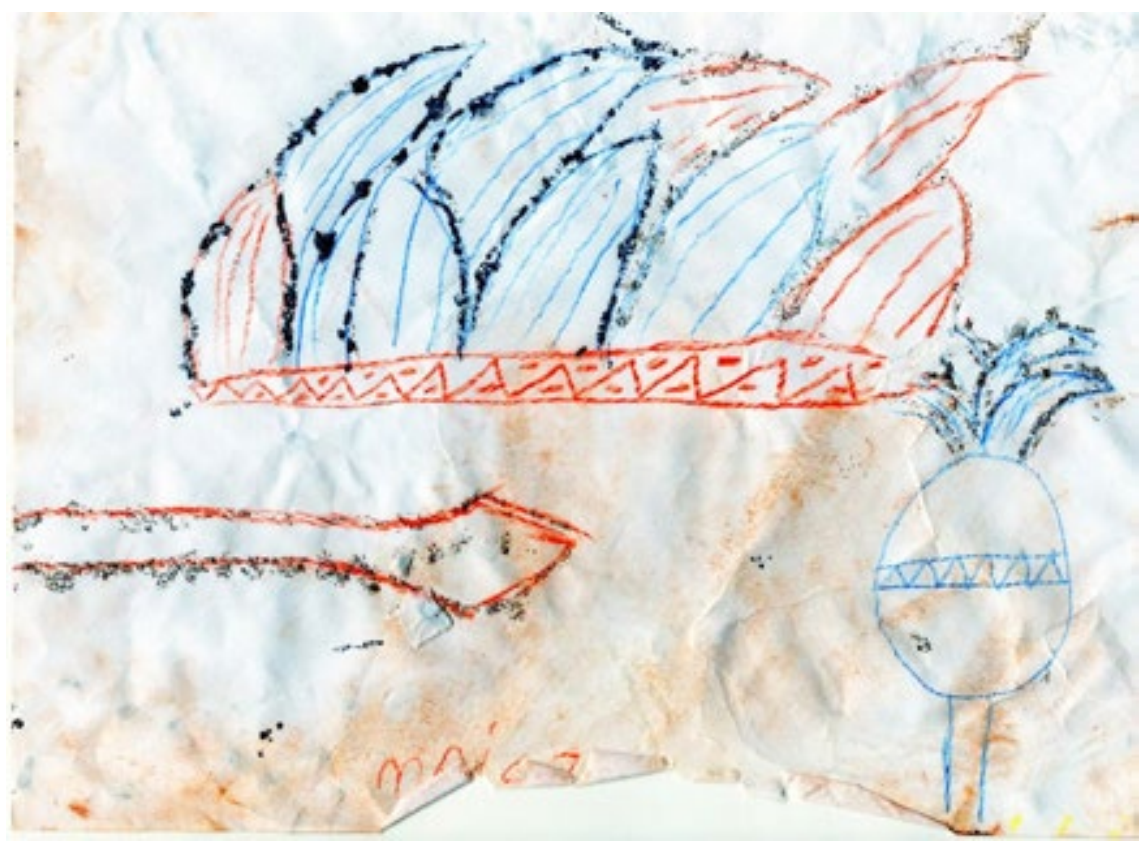

Fonte: Arquivos da pesquisa, 2014

O desenho seguinte (Figura 5) apresenta a significativa quantidade e variedade de temas contidos no imaginário: da flora (árvores), da fauna (tatu, cobra e "cachorro"), da terra (linha horizontal abaixo da casa que nos remete à existência de um solo), um lago, uma casa tradicional e uma casa de alvenaria. 
Figura 5 - Desenho classificado em vários grupos temáticos

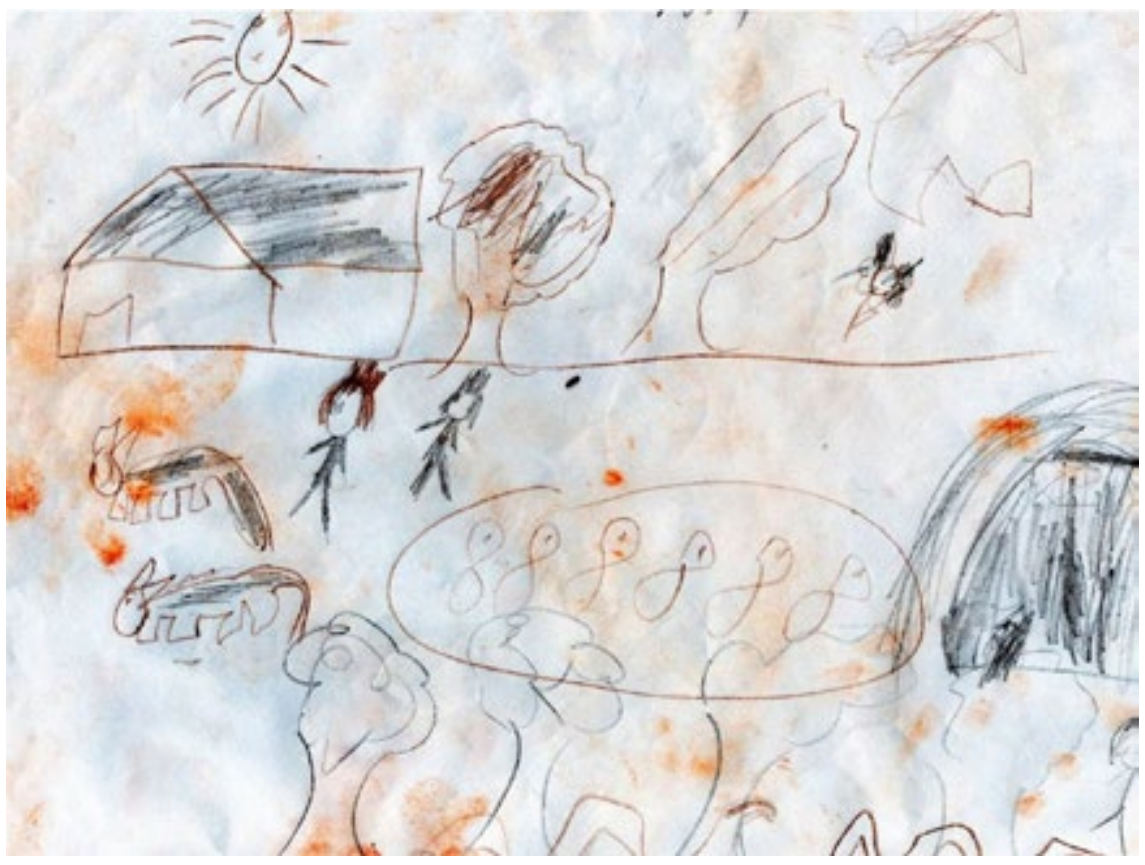

Fonte: Arquivos da pesquisa, 2014

O segundo momento aborda o desenho realizado por um dos netos do senhor Bonifácio. A criança escolhida foi Vanessa Martins Fernandes, de 11 anos. Vanessa foi colocada em destaque pelo próprio lider indígena e sua esposa, ao afirmar que a menina está sendo ensinada para ocupar um lugar significante na luta pela posse do tekoha. Em um dos encontros com Vanessa, foi deixado com ela um caderno de desenho (A5) e foi pedido que ela desenhasse o que mais gostava em sua vida, seja na escola, seja na casa de sua tia na aldeia Bororó/MS, seja na aldeia Pakurity. Vanessa realizou o seguinte desenho: 
Figura 6 - Desenho de Vanessa

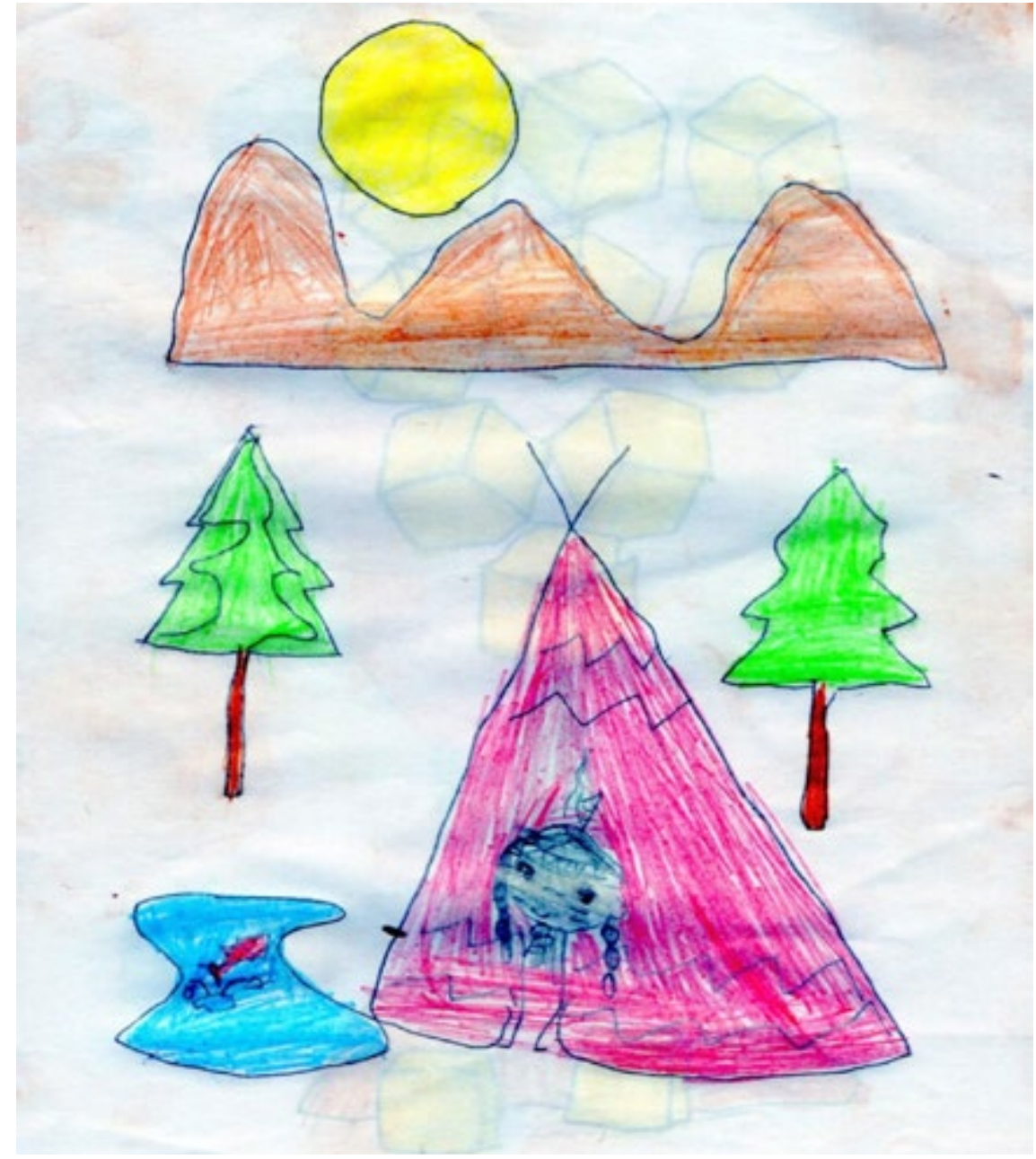

Fonte: Arquivos da pesquisa, 2016

Ao ser indagada sobre o significado do desenho, ela disse que é: "sou eu em casa no acampamento". Nota-se que dentro da casa tem uma pequena menina indígena, fazendo, assim, referência a ela. Continuei: que acampamento? E, com um leve sorriso no rosto, respondeu: o Pakurity! Ué! Indagação que provocou as palavras como resposta natural dentro de sua lógica. Entendemos, a partir dessas manifestações, que o que esta criança mais gosta é viver no "acampamento Pakurity". 


\section{Considerações finais}

"É bom morar no mato!". Afirmação dita por uma das crianças do Pakurity ao ser indagada sobre o que achava de viver no tekoha Pakurity. Diante dessa declaração e dos desenhos aqui apresentados, podemos inferir que o território é um espaço próprio de constituição e vivência identitária, principalmente se levado em conta que, para as crianças indígenas, esta relação é chamada de ñande reko, quer dizer, "nosso jeito de ser". Por esse motivo, neste texto defendemos a noção da autonomia, mesmo que relativa, das crianças nas relações com os adultos, com o ambiente e com a aldeia/ tekoha. As crianças são sujeitos que elaboram seus próprios códigos de comportamento de acordo com suas experiências e necessidades, sempre em contato com o mundo exterior, em contato com outras crianças e também com os adultos.

Diante da luta pelo território e do significado que este possui para os Kaiowá e Guarani, acredita-se que essa profunda relação física, afetiva, espiritual e simbólica com a terra também seja desenvolvida pelas crianças. Essa constatação choca-se com a realidade atual das comunidades Kaiowá e Guarani, em especial, as que estão em situação de acampamento, realidade de extrema vulnerabilidade e desrespeito aos direitos humanos básicos dessa população. Essa realidade histórica de perda do território tradicional e suas consequências seguem comprometendo o modo de ser tradicional desse povo (ñande reko), assim como compromete o crescimento saudável dessas crianças e todos os direitos garantidos no ordenamento jurídico nacional e internacional. 


\section{Referências}

AGUILERA URQUIZA, A. H (Org.). Cultura e História dos Povos Indígenas em Mato Grosso do Sul. Campo Grande/MS: Ed. UFMS, 2013. 334 p.

AGUILERA URQUIZA, A. H.; NASCIMENTO, A. C. (Org.). Crianças Indígenas: Diversidade Cultural, Educação e Representações Sociais. Brasília: Liber Livro, 2011.292 p.

ARIÈS, Philippe. História social da criança e da família; tradução de Dora Flaksman. 2. ed. Rio de Janeiro: LTC, 2012.

BARBOSA DA SILVA, Alexandra. Mais além da "aldeia": território e redes sociais entre os Guarani de Mato Grosso do Sul. Universidade Federal do Rio de Janeiro. Museu Nacional Programa de pós-graduação em antropologia social. Rio de Janeiro, 2007.

BRAND, Antônio. O confinamento e seu impacto sobre os Pãi/Kaiowá. Dissertação (Mestrado em História), PUC - Porto Alegre, 1993.

BRAND, Antônio. O impacto da perda da terra sobre a tradição kaiowá/guarani: os difíceis caminhos da Palavra. Tese de Doutorado em História - PUCRS, Porto Alegre, 1997.

BRAND, Antônio. Os complexos caminhos da luta pela terra entre os Kaiowá e Guarani no MS. Tellus, Campo Grande, v.3, n.4, p. 137-145, 2004.

CAVALCANTE, Thiago Leandro Vieira. Colonialismo, Território e Territorialidade: a luta pela terra dos Guarani e Kaiowá em Mato Grosso do Sul. 2013. 470f. Tese (Doutorado em História) - Faculdade de Ciência e Letras, Universidade Estadual Paulista, Assis, 2013.

CHAMORRO, Graciela. História Kaiowá. Das origens aos desafios contemporâneos. São Bernardo do Campo: Nhanduti Editora, 2015, 320 p.

CIMI. As Violências Contra os Povos Indígenas em Mato Grosso do Sul. 2010. http:// www.cimi.org.br/pub/MS/Viol_MS_2003_2010.pdf. Acessado em: 9 jun.2016, às 17h30.

CIMI. Relatório Violência contra os povos indígenas no Brasil. 2014. http://www.cimi. org.br/pub/MS/Viol_MS_2003_2010.pdf. Acessado em: 9 jun. 2016, às 17 h30.

COHN, Clarice. Antropologia da criança. Rio de Janeiro: Jorge Zahar Ed., 2005.

CORREA FILHO, V. À Sombra dos Hervaes Matogrossense. São Paulo: Ed. São Paulo, $1925,84 \mathrm{p}$.

CRESPE, Aline Castilho. Acampamentos indígenas e ocupações: novas modalidades de organização e territorialização entre os Guarani e Kaiowa no município de Dourados - MS: (1990-2009). 2009. Dissertação de Mestrado. Programa de Pós-Graduação em História da UFGD. 2009. 
EREMITES DE OLIVEIRA, J.; PEREIRA, L. M. Reconhecimento de territórios indígenas e quilombolas em Mato Grosso do Sul: desafios para a antropologia social e a arqueologia em ambientes colonialistas. In: AGUIAR, Rodrigo Luiz S. et al. (Org.). Arqueologia, Etnologia e Etno-história em Iberoamérica: fronteiras, cosmologia e antropologia em aplicação. Dourados: Editora UFGD, 2010, p. 185-208.

FERREIRA, Eva Maria Luiz. A participação dos índios Kaiowá e Guarani como Trabalhadores nos ervais da Companhia Matte Larangeira (1902-1952). Dissertação de Mestrado em História Indígena. UFGD. 2007.

IBGE. Instituto Brasileiro de Geografia e Estatísticas, 2010.

LOPES DA SILVA, A.; MACEDO, A. V. L. da SILVA; NUNES, A. (Orgs.). Crianças indígenas: Ensaios Antropológicos. São Paulo: Global, 2002.

LUCAS, S. R.; AGUILERA URQUIZA, A. H. Tô aqui... Parece que tô renascendo tudo de novo": experiências de campo sobre a retomada da terra e a retomada cultural dos acampamentos Pakurity e Laranjeira Ñanderu. Revista Nanduty, Dourados - MS. v. 3, n. 3: Dossiê Educação Indígena - Miscelânea | janeiro a junho de 2015.

MURA, Fábio. À procura do “bom viver”. Território, tradição de conhecimento e ecologia doméstica entre os Kaiowá. Universidade Federal do Rio de Janeiro. Museu Nacional. Programa de Pós Graduação em Antropologia. Rio de Janeiro, 2006.

OLIVEIRA, Roberto Cardoso de. O trabalho do antropólogo. 3.ed. São Paulo: Editora Unesp, 2000.

PEREIRA, Levi Marques. Assentamentos e formas organizacionais dos Kaiowá atuais: o caso dos "índios de Corredor". Tellus, ano 6, n. 10, p. 69-81, abril 2006

PEREIRA, Levi Marques. No mundo dos parentes: a socialização das crianças adotadas entre os Kaiowá. In: LOPES DA SILVA, A.; MACEDO, A. V. L. da SILVA; NUNES, A. (Orgs.). Crianças indígenas: Ensaios Antropológicos. São Paulo: Global, 2002.

PEREIRA, Levi Marques. Mobilidade de processo e processo de territorialização entre os Guarani atuais. História em Reflexão, Dourados, v.1, n.1, p. 1-33, 2007.

PEREIRA, Levi M. Parentesco e Organização Social Kaiowá. 1999. 244p. Campinas. Dissertação (Mestrado em Antropologia Social). Universidade Estadual de Campinas, Instituto de Filosofia e Ciências Humana, 1999.

PEREIRA, Levi M. Demarcação de terras kaiowa e guarani em MS: ocupação tradicional, reordenamentos organizacionais e gestão territorial. Tellus. Campo Grande, ano 10, n. 18, p. 115-137, jan. / jun. 2010.

PEREIRA, Levi M. Imagens Kaiowá do Sistema Social e seu Entorno. 2004. 345p. Tese de doutorado em Antropologia (etnologia). Universidade de São Paulo - USP, 2004. 
SARMENTO, Manuel Jacinto. Conhecer a infância: os desenhos das crianças como produções simbólicas. In: FILHO, Altino José Martins; PRADO, Patrícia Dias (Orgs.). Das pesquisas com crianças à complexidade da infância. Campinas: Autores Associados, 2011.

SCHADEN, Egon. Aspectos Fundamentais da Cultura Guarani. São Pulo. E.P.U./ EDUSP, 1974 [1954]

\section{SITES}

http://www.cimi.org.br/pub/RelatorioViolencia_dados_2013.pdf >. Acesso em: 3/11/2014. http://www.cimi.org.br/pub/MS/Viol_MS_2003_2010.pdf. Acessado em 09 de Junho de 2016 ás 17 hs.

http://indigenas.ibge.gov.br/images/pdf/indigenas/folder_indigenas_web.pdf. Acesso em $18 / 10 / 2015$ às 10 hs.

http://pib.socioambiental.org/pt/povo/guarani-kaiowa/554. Acesso em 18/10/2015;

http://pib.socioambiental.org/pt/povo/guarani-nandeva/1298 - acesso no dia 22/11/2013

http://www.funai.gov.br/index.php/2014-02-07-13-24-32.Acesso em 18/10/2015;

http://www.funai.gov.br/index.php/indios-no-brasil/terras-indigenas. Acesso18/10/2015.

\section{Entrevista}

Bonifácio Reginaldo Duarte: Entrevista [22 jan. 2014] Entrevistador: Sônia Rocha Lucas. Rio Brilhante (acampamento Pakurity), 2014. Anotações em caderno de campo. Entrevista concedida no âmbito do projeto de iniciação científica (PIBC/CNPq) desenvolvido por Sônia Rocha Lucas junto à Universidade Federal de Mato Grosso do Sul.

Bonifácio Reginaldo Duarte: Entrevista [16 abril. 2016 ] Entrevistador: Sônia Rocha Lucas. Dourados (acampamento Pakurity), 2016. Anotações em caderno de campo e filmagem. Entrevista concedida no âmbito do projeto de mestrado (Antropologia - UFGD). 


\title{
8. RELAÇÕES INTERCULTURAIS EAS EXPECTATIVAS DE ESTUDANTES ESTRANGEIROS EM UMA ESCOLA DE FRONTEIRA
}

\author{
Emanuelly Cristiny Vieira Rodrigues (PPGP/MAPSIIUNIR) \\ Maria Ivonete Barbosa Tamboril (PPGP/MAPSIIUNIR)
}

\section{Entre fronteiras...}

Julgamos necessário iniciar este artigo informando que a pesquisa que deu origem a ele escolheu como local para o estudo um município chamado Guajará-Mirim, no estado de Rondônia, que se localiza em uma região fronteiriça entre o Brasil e a Bolívia, onde há um número considerável de famílias de bolivianos que lá residem e, consequentemente, se apresentam de forma expressiva, também dentro das instituições públicas de ensino.

Essa expressividade se dá em virtude de o fluxo migratório de bolivianos para o Brasil não ser recente. Todavia, após a promulgação de um acordo binacional, firmado entre o Brasil e a Bolívia por meio do Decreto N. 6.737, de 12 de janeiro de 2009 (BRASIL, 2009), através do qual se tornou possível obter permissão de ingresso, residência, estudo, trabalho, previdência social e concessão de documentos especiais a estrangeiros residentes em localidades fronteiriças, essa realidade ficou bem mais evidenciada.

Em regiões de fronteira, normalmente a movimentação de imigrantes já ocorre muito antes da promulgação desse decreto e em Guajará-Mirim; essa realidade não é diferente. Estrangeiros que, junto com suas famílias, chegam ao município e a outras partes do país e optam por residirem no Brasil, somaram, no ano de 2010, de acordo com o Instituto Brasileiro de Geografia e Estatística (IBGE), mais de 250 mil pessoas advindas de diversas partes do mundo. Segundo esse mesmo Censo, os bolivianos 
ficaram em quinto lugar entre as nacionalidades que mais se destacam pela quantidade de imigrantes residentes - legalmente ou não - no país.

Nesse contexto, percebemos que existe uma realidade crescente e considerável de imigração, que chama atenção não apenas pela proximidade com outros países, mas pela permanência desses estrangeiros nas regiões para a qual imigraram. Em Rondônia, esta realidade pode ser facilmente identificada nas relações estabelecidas nas cidades fronteiriças, como é o caso de Guajará-Mirim, que faz divisa com a cidade boliviana chamada Guayaramerin.

Apesar da proximidade das regiões, os motivos que levam esses sujeitos a imigrarem podem ser os mais diversos. No caso da Bolívia, eles baseiam-se, geralmente, em questões econômicas.

Segundo o Índice de Desenvolvimento Humano (IDH) da Organização das Nações Unidas (ONU), a Bolívia se situa entre os países com um nível de desenvolvimento intermediário, ocupando, em 2003, a posição 114 entre 175 países, e em 2007 a posição 104 do ranking. Tais índices são influenciados pela inconstância econômica do país (CUNHA, 2004; MAGALHÃES, 2010)

Esse país, segundo o prognóstico da Comissão Econômica para a América Latina e Caribe (CEPAL, 2014), teve um aumento do PIB de até $5,5 \%$ em 2014. Todavia, a instabilidade na economia se tornou um vilão para muitas famílias, culminando com a evasão da população em direção a outros países.

O aumento da pobreza e dos distanciamentos de classes fez com que os grupos minoritários se tornassem ainda mais frágeis, do ponto de vista econômico e social, eclodindo sobre a sociedade boliviana e o seu desenvolvimento como um todo (NOGUEIRA, 2007). Tal situação tornou-se uns dos aspectos que motivaram e ainda motivam muitas famílias de imigrantes bolivianos a mudarem de país e escolherem, entre outros países, o Brasil para reiniciarem suas vidas.

A imigração, de forma geral, se configura como um processo social que, ao mesmo tempo que envolve decisões individuais, atinge o coletivo. De acordo com Ruivo (2006), refere-se ao movimento de entrada em um 
dado país, região, cidade, geralmente motivado por algo que faz o sujeito abandonar a sua comunidade de origem.

Essa motivação está ancorada em ideias positivas que são construídas sobre o lugar de destino, as quais são veiculadas, em geral, pela imprensa ou ainda pelos agenciadores de imigrantes no local de partida (SILVA, 2006). Isso permite que o indivíduo crie algumas representações a respeito do local para o qual pretende se mudar, fantasiando, assim, algumas realidades que, muitas vezes, são bem distantes das condições reais.

Em Guajará-Mirim, o que se observa é que as famílias que imigraram e permaneceram situam-se à margem da sociedade, seja por ocuparem funções consideradas inferiores, seja por residirem em bairros distantes ou por dependerem de um assistencialismo que provém mais da ajuda dos colegas imigrantes do que do próprio Estado. Portanto, podemos afirmar que a relação que existe entre brasileiros e bolivianos não se baseia nos princípios da igualdade, ao contrário, o comportamento que apresentamos mais parece a continuidade de uma história de dominação e poder.

Diante do exposto, o objetivo principal foi analisar as relações interculturais no processo de escolarização de estudantes bolivianos em uma escola pública na cidade de Guajará-Mirim - Rondônia, buscando identificar as possíveis dificuldades que esses estudantes encontram na escola, devido às diferenças culturais no processo de escolarização, e procurando observar em que medida a presença desses estudantes altera as rotinas e programações da escola, além de atentar para a relação e atuação do corpo docente em meio a essa realidade.

Optamos por entender essa realidade do prisma que se forma e se estabelece nas relações interculturais dentro de uma escola de fronteira, atentando para o fato de como tais relações influenciam o processo de aprendizagem de estudantes imigrantes, tendo como referência a Escola Estadual de Ensino Fundamental "Durvalina Stilbem de Oliveira”. Essa escola é uma das instituições de ensino mais antigas do município, localizada próxima ao porto oficial e no bairro onde o maior número de bolivianos reside. 
A instituição possui mais de 400 estudantes, distribuídos entre as séries iniciais, o ensino fundamental e a Educação de Jovens e Adultos (EJA). Desse total, existem 15 estudantes estrangeiros, nascidos na Bolívia de onde migraram, 62 estudantes que nasceram em Guajará, mas com pais bolivianos, e 21 estudantes indígenas, números estes do ano de 2014 .

Atualmente, a escola é referência no município por investir em projetos que atendem às diferentes demandas culturais que chegam à instituição, destacando-se os projetos "Intercâmbio Brasil x Bolívia" (em execução) e o "Currículo Bilíngue" (em desenvolvimento).

O projeto "Currículo Bilíngue" pretende unir, juntamente com escolas do município do país vizinho, diferentes formas de atuação escolar que auxiliem no desenvolvimento dos estudantes imigrantes que estudam nos dois países. Para tanto, utiliza formação de políticas linguísticas e educacionais que objetivam avançar e sistematizar a educação de escolas que atendem a esses estudantes que não possuem a língua materna da instituição na qual estão estudando, auxiliando, desse modo, o seu processo de aprendizagem.

Então, para auxiliar-nos nesse desafio, caminhamos pelas literaturas que discorrem sobre fronteiras, imigração e escola, verificando as legislações que são usadas como base para nortear as ações, para, em seguida, debruçar-nos sobre debates e pesquisas contemporâneas a respeito da interculturalidade e o seu papel dentro da educação.

Unido a isso, começamos a busca pelos participantes que contribuíram na pesquisa por meio de entrevistas. Conseguimos o retorno de três que, com suas informações, nos ajudaram a compreender como acontece o seu processo de aprendizagem e que tipos de relações são construídas no início e durante a permanência desses sujeitos dentro da escola.

Para nos auxiliar no entendimento das informações que eram cedidas pelos entrevistados, optamos por realizar observações participantes aleatórias na escola, registrando-as em diário de campo. Essas observações permitiram-nos perceber a escola através do olhar de um imigrante, atentando para as formas de integração utilizadas por ela e o desenvolvimento das atividades cotidianas. 
Todos os dados adquiridos para este trabalho foram obtidos e produzidos com o intuito de apresentar melhor a singularidade dessa região. Motivou-nos o fato de que o número de bolivianos ser crescente no município, e fingir que não os percebemos é negar uma realidade que faz parte do nosso cotidiano.

A análise das informações fornecidas pelos três entrevistados - Pardal (15 anos), Andorinha (13 anos) e Bem-te-vi (14 anos) - nos mostrou que as situações vivenciadas por eles, em muitos aspectos de vida, e elementos destacados no processo de escolarização, se aproximam.

\section{Dialogando com diferentes conceitos de cultura}

No esforço de encontrar a melhor maneira para começar a entender o conceito de interculturalidade e suas múltiplas fronteiras (WALSH, 2009a), é imprescindível, primeiramente, delinear o conceito de cultura. Esse termo comumente utilizado em diferentes tipos de diálogos pode fazer referências distintas que justifiquem situações diversas do cotidiano.

Seguimos as escritas de Hall (2003) e de outros autores, que acreditam que não importa como surgiram ou como se manifestam as diferentes formas de cultura, mas sim o que fazemos com ela.

Assim, pudemos entender que a função da cultura é, dentre outras, a de proporcionar a permissão e adaptação do indivíduo ao meio social e natural em que vive, onde cada um, embasado por sua herança cultural, pode se comunicar não apenas por linguagem, mas também por comportamentos (SILVA; SILVA, 2006).

Portanto, existem diversos conceitos para "cultura", e defini-la pode parecer um trabalho bem complexo, principalmente quando lembramos que seu conceito possui uma divisão e classificação vasta. Termos como, por exemplo, multiculturalidade, transculturalidade e interculturalidade, de forma geral, tentam absorver e reconhecer as múltiplas diferenças culturais e as identidades nelas existentes.

Hall (2003) defende o multiculturalismo inferindo que ele possui características sociais com problemas de governabilidade apresentados por 
qualquer sociedade, nas quais diferentes comunidades culturais convivem e tentam construir uma vida em comum, ao mesmo tempo que retêm algo de sua identidade original.

Já o termo intercultural, segundo Fleuri (2003), tem sido utilizado para indicar realidades e perspectivas incongruentes entre si. Esse termo, produzido na América Latina, nos traz a compreensão sobre o pertencimento, mesmo que, em alguns momentos, ele tenha seu significado reduzido a questões folclóricas, o que não auxilia no entendimento sobre a compreensão da singularidade de cada grupo.

Paralelamente a esses dois termos, encontramos o conceito de transculturalidade que, para Fleuri (2003), é entendido como um elemento transversal já presente em diferentes culturas e também como produto original da hibridização de elementos culturalmente diferentes. Sanches (2011) já acredita na hipótese de que o termo se vincula à ideia de híbridas identidades que se mesclam em cada indivíduo contemporâneo, fazendo assim que a realidade o convide para transformações no campo da educação.

Dinâmicas migratórias são exemplos dessas representações, que envolvem a temática de cultura de forma abrangente e, muitas vezes, desenfreada, posto que impera a lógica de que, se eu pertenço a uma determinada cultura, ela, naturalmente, me acompanhará para onde eu for.

Entretanto, soa muito perigoso defender essa proposta, já que os fenômenos culturais são distintos e, com o advento da globalização, a ideia de uma suposta cultura de massa, onde tudo se nivela, cada vez mais faz com que a criação de uma identidade e cultura únicas sejam substituídas pelas reafirmações de identidades e culturas individuais ou próprias, criadas em muitos momentos em virtude de fenômenos culturais recentes.

Partindo desse pressuposto, acreditamos ser relevante destacar de que forma a interculturalidade se apresenta, uma vez que já temos a compreensão de que a cultura pode se manifestar de diversas formas e ser distinguida de acordo com várias expressões, objetivando, desse modo, a criação de um debate a respeito da relação entre educação e diferenças culturais. 


\subsection{Sobre a interculturalidade}

Desde meados dos anos 1990, o termo interculturalidade vem sendo muito utilizado, tornando-se, juntamente com a multiculturalidade, temas que viraram moda (WALSH, 2009a). Nessas discussões, basicamente, utilizam-se novas narrativas que incluem distintas abordagens culturais, dentro do campo das Ciências Humanas e Sociais (DAMAZIO, 2008).

$\mathrm{O}$ uso da terminologia interculturalidade gera polêmica por ser defendida de inúmeras formas, todavia, as propostas de Moreira e Candau (2008), que entendem que a interculturalidade surgiu de uma perspectiva que propõe um multiculturalismo mais aberto e interativo, parecem ser as que mais se aproximam do entendimento aqui adotado.

Reyna (2007) afirma que cada um dos termos e seu uso são de extrema importância, posto que eles possibilitam a abertura de novos campos do saber contemporâneo, novas ideias e novos resultados de descreverem o mundo.

Isso, para a sociedade, surte um efeito extremamente positivo, visto que novos conhecimentos podem fazer com que os sujeitos interessados aperfeiçoem suas ideias e pensamentos, principalmente dentro do espaço escolar, onde as pessoas passam a adquirir formas mais críticas de absorverem todos os acontecimentos que as cercam.

Com mais de sete bilhões de habitantes no mundo, fica impossível entender e definir todas as dinâmicas sociais vigentes, sendo os espaços compostos por múltiplas realidades culturais que se encontram e se transformam ou se encontram e se destroem.

A interculturalidade, portanto, busca promover relações dialógicas e igualitárias entre pessoas e grupos que pertencem a universos culturais diferentes, trabalhando os conflitos inerentes a essa realidade (DAMAZIO, 2008).

Contudo, não podemos desconsiderar o que Olivé (2004) muito bem pontuou sobre a impossibilidade de evitar a diversidade, uma vez que a capacidade que temos de manejar a língua, de conectar ideias, fazer inferên- 
cias, aceitar crenças, normas e valores, com bases em razões, varia ao longo da história e muda de acordo com cada cultura.

A interculturalidade aparece então como uma estratégia para favorecer a coesão social, assimilando os grupos socioculturais subalternizados à cultura hegemônica, apontando a construção de sociedades que assumam as diferenças como constitutivas da democracia, que sejam capazes de construir relações novas, verdadeiramente igualitárias entre os diferentes grupos socioculturais, propondo empoderar aqueles que foram historicamente inferiorizados (CANDAU, 2012).

Entretanto, como sabemos, toda generalização soa um tanto contraditória, por isso Walsh (2009a) nos alerta para o risco de que esse reconhecimento e respeito à diversidade cultural, que tanto é destacado, possa se converter em uma nova estratégia de dominação, que aponta não para a criação de sociedades mais equitativas e igualitárias, mas ao controle do conflito étnico e à conservação da estabilidade social, com a finalidade de impulsionar os imperativos econômicos, com ajuda dos grupos historicamente excluídos em seu interior.

Geralmente, quando se assume um diálogo intercultural, escolhe-se uma abordagem que focaliza atenção a diferentes grupos socioculturais, com o objetivo de superar as tensões que Delors (2010) acredita ser o que danifica o mundo no século XXI. Porém, políticas específicas precisam ser bem sinalizadas, para que não sejam aplicados apenas modelos neoliberais de conduta dentro da sociedade.

Desse modo, acreditamos, assim como Reyna (2007), que essas temáticas e problemáticas sempre trazem consigo um número abundante de literatura que proporcionam várias definições e interpretações, e todas elas mostram as distâncias entre ambos os termos - interculturalidade e multiculturalidade -, que ocorrem por conta do prefixo que acompanha cada um deles.

Por isso, nosso caminho neste estudo está orientado para defender a interculturalidade. De fato, entendemos que não há justificativa para criação de novas culturas, oriundas de "pedaços" considerados importantes ou de destaques das culturas que compõem as relações, mas sim a reflexão a 
respeito de como podem ser trabalhadas culturas diferentes, em um mesmo lugar, sem favorecer uma em detrimento de outras.

\subsection{Inteculturalidade na educação}

Sabemos que existem diferentes culturas dentro do ambiente escolar, e essa singular riqueza cultural incita diversos pesquisadores a se debruçarem e a debaterem sobre o assunto, apresentando essa realidade através de visões multiculturais e interculturais.

Essas diferenças fazem com que as relações sociais evidenciem cada vez mais dentro dos diversos tipos de cultura, tendo em sua configuração a ideia do rompimento das barreiras sociais e de classe. Tais barreiras, apoiadas nos princípios igualitários e democráticos que integram a compreensão de globalização, demonstram-se tão perversas e tecnicistas, a ponto de ditar não apenas os padrões de comportamento, mas também as culturas elitistas e discriminatórias dentro da sociedade como um todo (MCLAREN, 1999).

As culturas que se apresentam dentro do ambiente escolar podem manifestar-se, dentre outras formas, através de uma dinâmica nova e independente, como é o caso das imigrações internacionais, que ocorrem devido aos fluxos migratórios vividos pela humanidade ao longo dos tempos, que pluralizam as culturas pré-existentes e diretamente afetam o sistema educacional como um todo (RODRIGUES; SOUZA, 2008; FLEURI, 2003).

$\mathrm{O}$ imigrante, ao chegar a determinado país (com a intenção de se fixar), muitas vezes encontra-se em estado de ilegalidade. Todavia, por se tratar de questões humanas, não se podem negar os direitos fundamentais que esses sujeitos possuem, dentre eles os direitos educativos, que se iniciam na sua inserção dentro da escola.

Esses direitos, baseados em premissas de diversos marcos legais, propõem a convivência democrática entre diferentes grupos e culturas, tendo a educação inclusiva como uma proposta que surge para a democratização do ensino, visando assegurar uma educação de qualidade para todos. Essa 
perspectiva se configura como uma promessa de educação para a alteridade, aos direitos do outro, à igualdade de dignidade e de oportunidades (FLEURI, 2006).

Quando falamos de relações baseadas em diferentes grupos sociais, podemos incluir nessa perspectiva estudantes de minorias raciais, residentes em favelas, com etnias diferentes, que possuem algum tipo de auxílio financeiro (bolsas concedidas pelo governo), imigrantes e outros marginalizados que procuram fazer parte das instituições escolares de forma igualitária.

De acordo com Fleuri (2006), uma das primeiras preocupações que emergem, ao se focalizar o tema de diferenças socioculturais, diz respeito ao entendimento e enfrentamento dos estereótipos culturais, preconceitos, discriminação e racismo, assim como dos processos de inclusão e exclusão social e institucional.

Quando pensamos em temáticas que abordam as questões da igualdade, da diferença e da desigualdade, sempre questionamos em quais momentos essas situações aparecem dentro do universo escolar. Diante disso, acreditamos que é necessário que a abordagem sobre tais termos seja a mais profunda e relevante possível, para que as análises e propostas solucionadoras também sejam condizentes com as realidades apresentadas.

Esse debate sempre rodeia o universo escolar nos seus âmbitos pedagógicos, psicológicos e políticos, relacionando a inclusão de estudantes dentro da realidade escolar.

O reconhecimento da possibilidade de aproximação e de diálogos entre sujeitos diferentes dentro do ambiente escolar traz à tona a concepção do estabelecimento da interculturalidade apresentada nesse universo. Como ela, desde seus momentos iniciais, tem significado uma luta na qual estão em permanente disputa assuntos como identificação cultural, direito e diferença, autonomia e nação, não é de se estranhar, nesse sentido, que um dos espaços centrais desta luta seja a educação, como instituição política, social e cultural, onde se cria um espaço de construção e reprodução de valores, atitudes e identidades e do poder histórico-hegemônico do Estado (WALSH, 2009b). 
As relações interculturais, de forma geral, se configuram na perspectiva de interação e evolução homogênea de diferentes culturas que congreguem pacificamente o mesmo espaço. Dentro do espaço escolar, isso também precisa ser otimizado, eliminando a visão curricular que demanda conteúdos escolares dedicados exclusivamente às culturas consideradas hegemônicas, ao mesmo tempo que ocultam ou desvalorizam as culturas populares (PANSINI, 2013).

O papel da escola e, em especial, do professor, tem uma grande relevância no que diz a respeito à inclusão e aprendizagem desse estudante imigrante e de sua cultura, uma vez que, se buscando respeitar a natureza do ser humano, o ensino dos conteúdos não pode se dar alheio à formação moral do educando (FREIRE, 2007).

\section{Entrada e permanência de estudantes imigrantes no sistema educacio- nal deGuajará-Mirim: desafios e possibilidades}

A imigração é um fenômeno muito antigo que faz parte da própria constituição da humanidade e até hoje aparece como um complexo desafio a ser superado pelas sociedades. Vários são os motivos que fazem um cidadão sair de seu país em busca de uma nova localidade para viver e, nesse sentido, também são vários os motivos que determinam a escolha desse novo local.

Em relação ao boliviano que chega ao Brasil, segundo uma pesquisa realizada na cidade de São Paulo, o principal motivo relaciona-se com o nível econômico desses sujeitos, sendo seu interesse primordial, no percurso de mudança de país, conseguir um emprego e melhorar sua situação financeira.

A decisão de imigrar geralmente tem a ver com a situação econômica vivenciada por muitas famílias, que tem como efeito uma tomada de decisão por parte dos adultos da família. Essa ação, através de um processo involuntário, acaba envolvendo as crianças e adolescentes que fazem parte dessas famílias, posto que elas, como regra, acabam acompanhando seus pais nesse trajeto de luta por condições mais adequadas de sobrevivência. 
De acordo com Valenzuela e Julian (2014), essa realidade está cada vez mais comum, o que faz com que diversos setores que envolvem uma sociedade necessitem de reparos no acolhimento desses sujeitos.

No campo educacional não é diferente, visto que ele também necessita ser ajustado e isso, segundo as autoras, começa por um estudo sobre o processo de integração de crianças e adolescentes de famílias imigradas, para assim se trabalhar todo o contexto educativo em que eles estão inseridos.

\section{$3.1 \mathrm{O}$ direito à educação e os imigrantes}

Cada sistema que configura parte da vida do sujeito tem suas leis e diretrizes que sinalizam e determinam de que forma um país pode gerir diferentes situações.

Sobre a educação é sabido que existem várias leis, documentos, mobilizações e entidades que lutam regularmente pelo direito ao ensino igualitário e de qualidade. Esses movimentos definem de que formas tais direitos podem ser aplicados, a fim de resguardarem os interesses coletivos e individuais das pessoas.

De acordo com Bobbio (1992), a valorização de tais leis foi um importante passo dado na direção da garantia do direito à educação, uma vez que elas são definidas como direito público subjetivo, pois a pessoa possui poder de proteger ou defender um bem considerado inalienável e ao mesmo tempo legalmente reconhecido.

Todavia, é importante frisar que o direito à educação é mais amplo que o direito à escola. Os processos educativos permeiam toda a vida das pessoas com diferentes dimensões e fases (SACAVINO, 2006).

No Brasil, o reconhecimento da importância da educação está representado na Constituição Federal do Brasil de 1988. Contudo, desse documento, outro foi formulado a fim de garantir e respeitar as necessidades básicas das crianças. Nomeado como "Declaração Universal dos Direitos das Crianças”, tem como objetivo, dentre outros, zelar pela sobrevivência dessa população dentro de nossa sociedade, ajudando na regulamentação 
de diferentes âmbitos que circundam a vida delas desde a infância até a sua adolescência.

Além dos documentos norteadores citados, no Brasil existe também o Estatuto da Criança e do Adolescente (ECA), promulgado em 1990, que prevê a proteção integral das crianças, definidas nessa lei como pessoas que possuem até doze anos incompletos, e adolescentes, que abrange os que possuem entre doze e dezoito anos de idade. Essa lei se aplica também, embora em caráter excepcional, aos que têm entre dezoito e vinte e uns anos de idade.

Todas essas leis possuem elementos de garantias que são de extrema relevância em todas as fases de vida do sujeito e, principalmente, na sua infância; todavia, mantê-las é o que torna o trabalho mais árduo, uma vez que falar de direitos não garante que eles serão devidamente aplicados quando a real necessidade surgir (BOBBIO, 1992).

Pensar em uma educação que alcance todos os públicos que possam vir a fazer parte de uma escola já é uma tarefa difícil, imaginamos então quando falamos de uma instituição que, além do público "comum”, precisa lidar com as diferenças e idiossincrasias de outros estudantes estrangeiros.

O Brasil, de acordo com dados do Censo do IBGE, abrigava em 2010 um pouco mais de 264 mil imigrantes; desses, 65\% são imigrantes brasileiros que retornavam ao país, restando ainda 35\%, que contabilizam 93 mil imigrantes de nacionalidade estrangeira que passaram a residir em diferentes estados da federação.

O aumento considerável de fluxo migratório no Brasil coloca à prova sérias propostas do sistema de ensino nacional, atentando para a sua real capacidade em lidar com as diversas situações que venham a surgir nas salas de aula, relacionadas às diferenças que existem dentro delas.

Indiscutivelmente, a investidura, nesse campo, oportuniza ao sujeito possibilidades e facilidades que diminuem as dificuldades de inserção que ele, como imigrante, naturalmente, já tem na sua transição para um país novo, ofuscando, desse modo, as possíveis diferenças que existem entre os 
que chegam e os que recebem; essa inserção, no entanto, não pode acontecer de qualquer forma.

De fato, para se inserir na rede de ensino do Brasil, o estrangeiro será amparado e terá como guia todas as obrigatoriedades e aplicações das leis baseadas nos direcionamentos descritos, conforme preveem a Constituição Federal e o Estatuto do Estrangeiro.

O Estatuto do Estrangeiro foi criado com o objetivo principal de dar ao imigrante a plena liberdade de entrar, fixar-se ou sair do Brasil em tempos de paz, respeitando todos os interesses da nação.

Esse Estatuto é um documento criado na época da Ditadura Militar Brasileira, que regula a situação dos imigrantes no Brasil, através da Lei número 6.815 de 19 de agosto de 1980, na qual fixa a estada legal desses estrangeiros no território brasileiro, além de caracterizar os seus direitos e deveres (BRASIL, 1980), criando, desse modo, uma perspectiva de melhoria no combate à desigualdade, racismo e preconceito às pessoas de nacionalidades diferentes dentro de um ambiente coletivo.

Mas, para de fato conseguir tais garantias, o estrangeiro precisa seguir uma série de regras necessárias para regularização dentro do país, para que assim suas necessidades e interesses sejam atendidos. Essa regularização inicia-se desde a entrada do sujeito, até a sua autorização legal, cuja concessão é fundamentada nas premissas do estatuto.

Esses requisitos são guiados pelas premissas determinadas no Estatuto do Estrangeiro e prezam, antes de tudo, legitimar principalmente a segurança nacional, a organização institucional, os interesses políticos, sociais, econômicos e culturais do Brasil, bem como a defesa do trabalhador nacional (BRASIL, 1980).

Após a efetivação dos processos burocráticos, o imigrante que deseja se inserir numa escola poderá iniciar as buscas por vagas e matrículas como qualquer cidadão brasileiro. Contudo, dentro da escola se inicia um novo passo: ultrapassar as dificuldades que poderão surgir em virtude da adaptação e apropriação à nova língua, aos novos amigos e à nova cultura escolar. 
3.2 Panorama sobre a educação em Guajará - Mirim e a inserção de estudantes imigrantes em uma escola de fronteira

Contando atualmente com 64 centros de ensino, Guajará-Mirim, devido à sua extensão, possui uma diversidade de instituições educacionais que operam para as diferentes classes e idades de estudantes. Por localizar-se em uma região fronteiriça, o município recebe frequentemente imigrantes bolivianos que se matriculam ou matriculam seus filhos na rede pública do município, sendo inexistentes matrículas nas instituições privadas.

Essa constatação foi obtida após um levantamento feito sobre as matrículas iniciais realizadas no ano de 2015, nas escolas públicas do município, identificando todas as matrículas feitas por estudantes estrangeiros.

Em pesquisa desenvolvida com os dados de matrículas das escolas do município, identificamos a presença de 109 estudantes de origem boliviana. Destes, 101 estão distribuídos nas dez escolas da rede estadual, enquanto apenas oito frequentam escolas na rede municipal, que mantém um total de 11 escolas no município.

A pesquisa, nas escolas, trouxe outro dado relevante que diz respeito à concentração desses estudantes. Foi observado que, dos 109 estudantes bolivianos matriculados, 28 deles estão na Escola Estadual Durvalina (aproximadamente 26\%), colocando a instituição em primeiro lugar no ranking das escolas que recebem estudantes estrangeiros no município, o que justificou a minha escolha por esse local do estudo.

A Escola Durvalina, como instituição diferenciada no sistema de inclusão e acolhimento de estudantes imigrantes e indígenas, possui projetos que, muitas vezes, são mantidos por interesse do corpo da escola, o que faz com que busque parceria, independente do suporte que a Secretaria Estadual se propõe a dar.

O plano da escola vislumbra o que Fleuri (2002) acredita ser primordial para uma educação intercultural de qualidade, segundo a qual o plano educativo busca a formação de cidadãos capazes de respeitar as diferenças culturais, não se limitando à descrição e localização das diferenças, mas reconhecendo que elas existem e precisam ser valorizadas. Afinal, como 
pontuado anteriormente, o direito à educação é mais amplo que o direito à escola.

\section{Considerações finais}

Os dados obtidos e considerados resultados dessa pesquisa trazem alguns apontamentos relevantes, destacados pelos entrevistados, que podem ser observados em um ambiente escolar de fronteira.

São eles:

1) Identificação dos estudantes: Observamos primeiramente que os estudantes imigrantes bolivianos que estudam em Guajará-mirim são, em sua maioria, crianças e adolescentes, que, junto com suas famílias, mudaram de país, com o intuito de conseguir estabilidade financeira e melhoria de condições de vida, não encontrada em sua terra natal. Geralmente são famílias de origem "colla" que, na própria Bolívia, já são inferiorizados, residentes em cidades próximas à fronteira ou que já possuíam parentes que viviam há bastante tempo no território brasileiro.

Ao cruzarem a fronteira, essas famílias passam a ter contato com outra cultura, e o entrosamento entre as duas nacionalidades é proporcionado pelo desenvolvimento das relações, que assim se iniciam.

2) Burocracia para inserção na escola: Depois de mudarem, as famílias que desejam matricular seus filhos na rede de ensino no município precisam, primeiramente, passar por um processo de regularização documental exigido dentro dos ambientes escolares brasileiros. O que, em geral, se torna uma primeira barreira a ser superada por esses estudantes, pois, para que eles possam ingressar em escolas brasileiras, precisam ultrapassar uma série de fases burocráticas, antes de conseguir os mesmos direitos de outros estudantes. Esses processos, muitas vezes, são longos e caros, principalmente se o imigrante estiver ilegal no país.

As dificuldades burocráticas, especialmente no caso dos ilegais, são as grandes vilãs de muitas famílias de imigrantes, que desejam matricular 
seus filhos em qualquer rede de ensino. Tal situação nos fez refletir a respeito da eficiência de alguns métodos, ainda adotados pelo Estado, que supostamente organiza a forma de recebimento dos imigrantes, mas faz isso através de trâmites ultrapassados, que constituem um grande percalço, emergindo negativamente na trajetória desses indivíduos.

Os estudantes entrevistados, e os demais que estão matriculados, superaram esse processo, todavia verificamos que um deles (Bem-te-vi) começou a estudar antes mesmo de conseguir toda documentação, em virtude de uma flexibilização da instituição escolar. Essa maleabilidade nos revela a sensibilidade da escola em não impedir o aluno de iniciar o ano letivo, juntamente com os outros estudantes, posto que isso poderia dificultar sua adaptação.

3) A atuação da escola: Por meio das observações, também foi possível constatar que existe na escola uma preocupação em preparar o ambiente para receber respeitosamente esses estudantes, através das identificações dos espaços feitas na língua portuguesa e na língua espanhola, evidenciadas durante todo o ano letivo. Além desses cuidados com o espaço físico, a escola possui um projeto em andamento e outro em desenvolvimento, em conjunto com uma escola na Bolívia, que visam valorizar essas diferenças culturais, propiciando aos estudantes uma aproximação com a realidade do país vizinho.

Esses indícios, por parte da instituição, demonstram uma preocupação genuína em receber bem esses estudantes, gestos que são sentidos e atestados por eles. Isso é comprovado quando os entrevistados afirmam que a linguagem não é considerada um empecilho no processo de adaptação e aprendizagem. $\mathrm{E}$ as possíveis dificuldades que surgem, em algumas disciplinas específicas (Geografia e Português), são ocasionadas por fatores alheios à questão da linguagem.

Nesse caso específico, entendemos que a escola pode auxiliar na busca por uma aproximação e estreitamento de laços com essa realidade, ao desenvolver métodos pedagógicos diferenciados junto aos docentes, talvez buscando conhecer como essas disciplinas são trabalhadas em outras loca- 
lidades para depois tentar uma adaptação da prática. Trata-se de alguns dos auxílios que podem contribuir ainda mais para o crescimento desses estudantes na escola e para o seu envolvimento com as relações estabelecidas.

4) O posicionamento dos docentes: Os resultados apontaram que, na Escola Durvalina, os docentes preocupam-se com o entendimento do conteúdo exposto em sala, principalmente no primeiro ano, posto que geralmente ele é o mais difícil. Para tentar melhorar as possíveis dificuldades, eles buscam, através do auxílio de alguns instrumentos, proporcionar ao estudante imigrante a possibilidade de acompanhar o restante da turma.

Esses instrumentos baseiam-se tanto na percepção da necessidade de eles próprios aprenderem a língua espanhola, quanto na sensibilização de acompanhar esses estudantes e seu desenvolvimento individual, dentro de sala. Além da participação ativa em todos os projetos que giram em torno da temática imigratória e da construção das relações culturais.

5) O imigrante na escola: Verificou-se que os três entrevistados estão cursando anos diferentes, mas não estão sozinhos na escola e nem mesmo em suas salas de aula, tendo conterrâneos na sala dos três, o que colabora com o processo de naturalização com que esses estudantes são recebidos e tratados pelos colegas de sala e professores.

Todos apontaram que suas experiências dentro da escola não apresentavam, até o momento da pesquisa, nada que lhes fizesse desejar sair da instituição ou até mesmo voltar para a sua escola anterior, no seu país.

As motivações iniciais que os trouxeram para o Brasil foram, em geral, econômicas, mas a preferência pela educação brasileira e a vontade de seguirem os estudos em nosso país coincidem, pela crença de todos na melhoria da qualidade de vida e na possibilidade de fazer uma faculdade e ascender profissionalmente.

$\mathrm{O}$ que nos remete ao entendimento da necessidade de se pensar em políticas públicas diferenciadas para o município e para as demais institui- 
ções que atendem essa clientela, enfatizando a peculiaridade que faz parte do cotidiano de cada escola da região. Acreditamos que exigir ou autorizar as escolas a receber esses estudantes, aplicando técnicas que são baseadas em realidades totalmente diferentes das do município, pode torna a educação bastante ineficiente para essa população específica.

É importante enfatizar que, mesmo com o trabalho desenvolvido pela "Durvalina" e diante dos números cada vez maiores de estudantes imigrantes, que são introduzidos na rede de ensino do município, a falta de apoio dos órgãos competentes e o pouco interesse,de outras instituições de ensino, farão com o que, no futuro, esse trabalho não surta tanto efeito, como o esperado para a região. A estrutura, o desenvolvimento e a aplicação de todos os meios necessários para abraçar essa realidade com maestria não se sustentam sozinhos e, no caso dessa escola específica, encerra-se no nono ano.

Desse modo, mesmo sendo tímidas tais constatações, acreditamos ser uma oportunidade interessante de despertar, coletivamente, esse sentimento de valorização do desenvolvimento das relações, que nos permite estimular o exercício da cidadania, através da atuação conjunta de membros de diversas áreas que compõem a sociedade, vislumbrando, assim, um pequeno progresso, nesse processo chamado igualdade, dentro dessa América maiúscula.

\section{Notas}

${ }^{i}$ Texto "As expectativas dos imigrantes bolivianos na cidade de São Paulo: reflexões sobre a comunicação intercultural", dos autores Dra. Mônica Ayala Soliz e Fábio Randigonda Serrato. Disponívelem:<http://www.revistaorganicom.org.br/sistema/index.php/organicom/ article/download/777/588> Acesso em: 20/03/2015.

ii É importante frisar que existe uma proposta de texto para uma nova Lei de Migrações, criada pela comissão de especialistas instituída pelo Ministério da Justiça que deverá substituir o Estatuto do Estrangeiro, tendo como principais propostas reforma no campo migratório, com a revisão administrativa no Departamento de Estrangeiros e do Comitê Nacional para os Refugiados (Conare); a publicação de portarias que desburocratizam procedimentos; criação de mecanismos participativos junto à sociedade civil; início da estruturação de unidades de atendimento e acolhimento pelos governos locais, com convênios federais; maior inserção brasileira nos organismos e foros internacionais sobre o tema. Disponível em: < http://www.brasil.gov.br/cidadania-e-justica/2014/08/nova-lei-de-migracoes-devera- 
-substituir-estatuto-do-estrangeiro >. Acesso:18/01/2015. Todavia, enquanto as novas mudanças não são instituídas, nos baseamos no Estatuto do Estrangeiro antigo para a escrita desse trabalho.

iii Dados informados na Secretaria Municipal de Educação (SEMED) / Prefeitura Municipal de Guajará-Mirim - RO.

\section{Referências}

BRASIL. Estatuto da Criança e do Adolescente. Lei Federal no 8069, de 13 de julho de 1990. Disponível em: www.planalto.gov.br/CCIVIL_03/leis/L8069.htm. Acesso em: 15 jan. 2015.

Planalto do Governo. Decreto - lei n. 6.737, de 12 de janeiro de 2009. Disponível em: <http://www.planalto.gov.br/ccivil_03/_ato2007-2010/2009/decreto /d6737.htm>. Acesso em: 23 nov. 2013.

Planalto do Governo. Estatuto do Estrangeiro. Decreto - Lei n. 6.815, de 19 de agosto de 1980. Disponível em: <http://planalto.gov.br/ccivil_03/leis/16815. 2 Acesso em: 15 jan. 2015.

BOBBIO, N. A era dos direitos. Rio de Janeiro: Campus, 1992.

COMISSÃO ECONÔMICA PARA A AMÉRICA LATINA E CARIBE (CEPAL). Perspectivas económicas de América Latina 2014: Logística y competitividad para el desarrolo. Disponível em: <www.cepal.org/brasil>. Acesso em: 5 jan. 2015.

CUNHA, A. M. Reflexões sobre a crise boliviana. Porto Alegre: UFRGS, 2004.

DAMAZIO, E. S. P. Multiculturalismo versus Interculturalismo: por uma proposta intercultural do Direito. Revista Desenvolvimento em questão, v. 6, n. 12, p. 63-86, Rio Grande do Sul, 2008.

FLEURI, R. M. A produção das diferenças pela escola. In: NEVES, J. G. et al. (Org.). Escolarização, cultura e diversidade: percursos interculturais. Porto Velho: EDUFRO, p. 10-17, 2013.

FLEURI, R. M. Intercultura e educação. Revista Brasileira de Educação, n. 23, p. 16-35, São Paulo, 2003.

FLEURI, R. M. Desafios à educação intercultural no Brasil. In: FLEURI, R. M (Org.). Intercultura: estudos emergentes. Ijuí-RS: Unijuí, 2002.

FLEURI, R. M. Políticas da Diferença: para além dos estereótipos na prática educacional. Educação e Sociedade, v. 27, n. 95, p. 495-520, Campinas, 2006.

FREIRE, P. Pedagogia da autonomia: saberes necessários à pratica educativa. São Paulo: Paz e Terra, 2007. 
HALL, S. A questão multicultural. In: HALL, S. Da diáspora. Belo Horizonte: Editora UFMG, 2003.

INSTITUTO BRASILEIRO DE GEOGRAFIA E ESTATÍSTICA - IBGE. Censo 2010. Disponível em: <http://www.cidades.ibge.gov.br/download/mapa_e_municipios. php?lang=\&uf=ro $>$. Acesso em: 6 jan. 2015.

MAGALHÃES, G. M. Fronteiras dos direitos humanos à educação: Um estudo sobre os imigrantes bolivianos nas escolas públicas de São Paulo.2010. (Dissertação) Faculdade de educação da Universidade de São Paulo: 2010.

MCLAREN, P. Utopias provisórias: as pedagogias críticas num cenário pós-colonial. Petrópolis, RJ: Vozes, 1999.

MINAYO, M. C. S. O desafio do conhecimento: pesquisa qualitativa em saúde. São Paulo: Hucitec, 2008.

MOREIRA, A. F.; CANDAU, V. M. F. Multiculturalismo: Diferenças culturais e práticas pedagógicas. Petrópolis: Vozes, 2008.

NOGUEIRA, D. de A. M. Diplomacia do gás: a Petrobras na política externa de Cardoso para a integração energética com a Bolívia (1995-2002). Instituto de Relações Internacionais, Pontifícia Universidade Católica do Rio de Janeiro, 2007.

OLIVÉ, L. Interculturalismo y justiça social: Autonomia e identidad cultural en la era de la globalización. 2004. (Dissertação) Universidad Nacional Autonoma do México, 2004.

PANSINI, F. Educação como diálogo de sujeitos: as culturas no espaço escolar. In: NEVES, J. G. et al. (Orgs.). Escolarização, cultura e diversidade: percursos interculturais. Porto Velho: EDUFRO, 2013.

RODRIGUES, A. L.; SOUZA, R. Q. A educação na fronteira: 0 caso dos alunos bolivianos na rede pública e particular de Corumbá / MS. Mato Grosso do Sul: UFMS, 2008. Disponível em: <http://migre.me/rMzhC>. Acesso em: 20 nov. 2013.

RUIVO, P. A imigração: uma visão geral. Coimbra: Universidade de Coimbra, 2006.

SACAVINO, S. Direito a educação no Brasil: uma conquista para todos/as? ENCONTRO NACIONAL DE DIDÁTICA E PRÁTICA DE ENSINO, 13. Programa de Pós-Graduação em Educação da Universidade Federal de Pernambuco: Recife: 2006. Anais... Disponível em: <http://migre.me/rMzhd>. Acesso em: 8 mar. 2015. 
SANCHES, S. C. P. Pressupostos para pensar a alteridade no ensino de artes visuais na educação básica em Mato Grosso do Sul. Revista Interfaces da Educação, Paranaíba, v. 2, n. 5, p. 50-62, Paranaíba.

SILVA, K. V.; SILVA, M. H. Dicionário de Conceitos Históricos. São Paulo: Contexto, 2006.

SILVA, S. A. Bolivianos em São Paulo: entre o sonho e a realidade. Estudos Avançados, n. 20, p. 157- 170, São Paulo, 2006.

VALENZUELA, L. A. B.; JULIÁN, B.P. Educación intercultural en Chile: la integración del alumnado extranjero en el sistema escolar. Educ. Educ. v. 17, n. 3, p. 405-426, 2014.

WALSH, C. Interculturalidad, Estado, Sociedad: Luchas (de)coloniales de nuestra época. Quito: Ediciones Abya - Yala, 2009a.

WALSH, C. Interculturalidade crítica e educação intercultural. La Paz: Instituto Internacional de Integración del Convenio Andrés Bello, 2009b. Disponível em: <http://migre. me/rMzge >. Acesso em: 23 jan. 2015. 


\section{POVOS INDÍGENAS EM RONDÔNIA: \\ O ENSINO SUPERIOR COMO \\ NOVA FERRAMENTA FRENTE À \\ COLONIALIDADE}

Thaís Oliva Fernandes Sanders (PPGE/UFMT)

\section{Introdução}

Este texto apresenta uma interpretação das distintas fases do processo de colonização de exploração e de povoamento do estado de Rondônia, e sua decorrência para os povos indígenas originários da região, tendo como referência a noção de colonialidade. Essa contextualização objetiva conhecer o cenário histórico em que se apresenta o Curso de Licenciatura em Educação Básica Intercultural - LEBI, a fim de compreender a proveniência do perfil docente indígena manifesto na formação acadêmica.

As bases teóricas desta investigação são desdobramentos de estudos e pesquisas realizadas junto ao Programa de Pós-Graduação em Educação da Universidade Federal de Mato Grosso (PPGE/UFMT), especificamente no âmbito do Grupo de Estudos e Pesquisa em Educação Escolar Indígena (GEPEEI).

Pelo fato de o referido Curso ser interpretado sob os aspectos pessoal, institucional e cultural, neste trabalho utilizou-se, como método, a pesquisa qualitativa de tipo etnográfica. Nesse sentido, "a principal preocupação da etnografia é com o significado que têm as ações e os eventos para as pessoas ou os grupos estudados na tentativa de descrever sua cultura e compreender seus significados" (ANDRÉ, 1995, p. 19).

Por conseguinte, como técnicas para a construção dos dados, no período de interação social entre o investigador e os sujeitos, utilizou-se da observação participante (diário de campo), análise documental, conversas informais e questionário. 


\section{Os povos indígenas no desenvolvimento do Estado de Rondônia}

A teoria de Lander (2005, p.13) sobre "a visão universal da história associada à ideia de progresso (a partir da qual se constrói a classificação e hierarquização de todos os povos, continentes e experiências históricas)" e a teoria de Quijano (2002, p. 1) sobre a "colonialidade do poder, isto é, a ideia de 'raça' como fundamento do padrão universal de classificação social básica e de dominação" retratam o processo histórico do estado de Rondônia.

No decurso do período de colonização de exploração ${ }^{1}$, marcado pelos Ciclos do Ouro e da Borracha, e para as construções da Ferrovia Madeira-Mamoré e das Linhas Telegráficas Rondon, segundo autores como Matias (1998) e Perdigão e Bassegio (1992), houve a prática da escravidão de negros, da servidão de indígenas, seringueiros, mineradores e demais trabalhadores, explorados intensivamente entre 1640 a 1940, com certo anacronismo até 1970, com a finalidade de manutenção da atividade econômica extrativista.

A subjugação da pessoa humana a essas condições somente foi possível dada a associação entre o conceito de progresso e raça, em que, supostamente, um descreve o outro. Nesse contexto, a priori teórico e em seguida naturalizado socialmente, a ausência do progresso local justifica-se pelas limitações atribuídas a raça das pessoas que o ocupam. Essa circunstância marca o processo político e social de colonização pelo qual o estado se estruturou e, fundamentalmente no que se refere aos povos indígenas como consequência, tem-se a corporificação e a naturalização de conceitos estereotipados com base fenotípica.

Esse discurso, mantido durante a colonização de povoamento, apresentava os indígenas em uma totalidade genérica, ao passo que, como evidencia Castro-Gómez (2005), promove a “invenção do outro" na medida em que o conhecimento que se tem sobre o outro é suficiente para

\footnotetext{
${ }^{1}$ Conforme Jefferson Evandro Machado Ramos existe dois tipos de colonização: de exploração e de povoamento. "Na colonização de povoamento, os colonizadores buscam desenvolver a região colonizada. Criam leis, organizam, investem em infraestrutura e lutam por melhorias:" A colonização de exploração explica o tempo durante o qual território se encontra conquistado ou invadido para a exploração. (Fonte: Sua Pesquisa.com e Dicionário Priberam da Língua Portuguesa).
} 
conhecê-lo e descrevê-lo, situação que finda o discurso. E como repercussão, por gerações, esse pensamento "se mantém arraigado nos esquemas culturais e de pensamento dominantes, legitimando e naturalizando as posições assimétricas” (PORTO-GONÇALVES; QUENTAL, 2012, p. 31).

Perante a imagem estereotipada dos povos indígenas, com a criação do Território Federal de Guaporé, em 1943, para intensificar o fluxo de povoamento, propagou-se a noção de "vazio demográfico", fundamental para o desenvolvimento da economia local, visando ao fortalecimento da estrutura política administrativa, condição necessária para sua elevação a estado.

Em meio à estruturação política, não era qualquer indivíduo legitimado à participação, contexto em que poucos possuíam as qualificações necessárias (compreende-se escolarizado e influente economicamente), para o exercício do poder administrativo, reforçando "a naturalização tanto das relações sociais como da "natureza humana" da sociedade liberal-capitalista” (LANDER, 2005, p.13).

Ainda, como mecanismo da naturalização das relações sociais da sociedade capitalista, manifestas no Território, tem-se a transformação da condição de servidão em conversão ao trabalho braçal, necessário ao desbravamento da região. E o assentamento populacional do Território, feito por empresas colonizadoras e programas do governo, que oficializavam o discurso de sociedade liberal-capitalista, ao desconsiderar qualquer forma de propriedade que não estivesse legitimada por um Estado administrador, o que acarretou na desterritorialização dos povos indígenas. Para Escobar (2005, p. 64),

Ao retirar ênfase da construção cultural do lugar a serviço do processo abstrato e aparentemente universal da formação do capital e do Estado, quase toda a teoria social convencional tornou invisíveis formas subalternas de pensar e modalidades locais e regionais de configurar o mundo.

Dessa maneira, a expansão demográfica da região ignorou os territórios indígenas no avanço do desenvolvimento regional, pois, no contexto de sociedade liberal-capitalista, "o lugar afirma-se em oposição ao domínio do espaço, e o não-capitalismo em oposição ao domínio do capitalismo como imaginário da vida social” (ESCOBAR, 2005, p. 68). 
Com a criação do Estado de Rondônia, em 1981, houve a quebra definitiva da estrutura espacial existente (abertura de estrada, derrubada, demarcação), para a criação de cidades, o estabelecimento do comércio, o aparelhamento do estado e o estímulo ao agronegócio.

As eleições diretas ocorridas no estado abordavam a ideologia de "povo rondoniense"; a ser materializada no voto, por um estado representativo, para indígenas, quilombolas, soldados da borracha e migrantes.. No entanto, a partir da ótica de Moreno (2005, p. 93), o "conceito ilustrado de povo, o que se veio usando em política, como o conjunto de toda a população constituída, em princípio, por iguais, já está claro que é uma ficção elaborada pelos que necessitam apagar abstratamente, mas não no concreto, as distinções”.

Nesse cenário, marcam-se os esforços dos povos indígenas para reorganização de seu modo de vida, dentro de um espaço politicamente organizado, que ultrapassava sua compreensão, em função da exclusão política de seus representantes, dada a ideologia de inferioridade racial e noção de progresso.

Como mecanismo para afirmar sua representação, na atualidade, presencia-se a criação de organizações indígenas, para assegurar, diante do Estado e nos seus respectivos poderes, direitos a educação, saúde, segurança e a legislação específica, fundamental para diminuição das desigualdades.

\section{A Universidade Federal de Rondônia e a presença da diversidade étnica Amazônica}

Pode-se dizer que a política educacional de ensino superior nacional sempre esteve focada na noção de desenvolvimento e modernidade, com base na experiência europeia, em função da naturalização da "superioridade dos conhecimentos que essa sociedade produz ('ciência') em relação a todos os outros conhecimentos”. (LANDER, 2005, p. 13). Desse modo, suas ações estiveram pautadas no conhecimento eurocêntrico, visando uma formação civilizadora, como condição para a prosperidade econômica da lógica capitalista. Logo,

As outras formas de ser, as outras formas de organização da sociedade, as outras formas de conhecimento, são transformadas não só em 
diferentes, mas em carentes, arcaicas, primitivas, tradicionais, prémodernas. (LANDER, 2005, p. 13).

Segundo Neto (1993), a ideologia para criação da Fundação Universidade Federal de Rondônia - UNIR, em 1982, surge por interesses "político-partidários", para ganhar força no interior do Estado com o projeto de educação superior, sem se preocupar com a política ideológica do cenário educacional nacional.

Desprovida de forças norteadoras para um processo de transformação social, a universidade é conduzida unilateralmente para manter a sustentação desses políticos, o que significa atribuir à educação uma função instrumental da vontade onipotente de uma classe dominadora. (NETO, 1993, p. 132).

Desse modo, a universidade esteve disponível para o estabelecimento de um processo civilizador/normalizador, incapaz de lidar com as diversidades de povos e culturas presentes na Amazônia, assentindo "desta maneira para ocultar, negar, subordinar ou extirpar toda experiência ou expressão cultural que não corresponda a esse dever ser que fundamenta as ciências sociais" (LANDER, 2005, p. 14).

Dada sua exclusão histórica do meio universitário público local, os povos indígenas, na contramão dessa ideologia, passaram a se aparelhar, logo após a formatura da primeira turma do Projeto Açaí ${ }^{2}$, no ano de 2004, para discutir e reivindicar a pauta de criação de um curso em licenciatura intercultural específico para professores indígenas na UNIR. Quijano compreende a luta por direitos como um momento de libertação da identidade, "quando os dominados da colonialidade do poder estão se reorganizando e se mobilizando"(QUIJANO, 1992, p. 76).

Nesse processo, tanto o que estabelecia a Lei de Diretrizes e Bases da Educação Nacional, Lei no. 9.394/96, como o Plano Nacional de Educação, Lei no. 10.172/2001, sobre formação docente em nível

$\overline{{ }^{2} \text { Faltou o texto desta Nota }}$ 
superior, se tornaram ferramentas jurídicas importantes para que o Núcleo de Educação Escolar Indígena de Rondônia ${ }^{3}$ - NEIRO, a Organização dos Professores Indígenas de Rondônia ${ }^{4}$ - OPIRON e, em Ji-Paraná, a Organização PADEREÉHJ ${ }^{5}$, requeressem a criação de um curso para formação de professores indígenas junto à UNIR ${ }^{6}$.

O marco inicial desse diálogo entre o NEIRO e a UNIIR dá-se com a formalização de um documento junto à instituição após o Seminário "A Universidade Indígena - Educação, Diversidade, Cidadania”, organizado por este núcleo, nos dias 19 e 20 de maio de 2005. Tais esforços culminam com a institucionalização do Curso de Licenciatura em Educação Básica Intercultural - LEBI, em 29 outubro de 2008, durante a reunião de deliberação do CONSEA? .

As discussões cobriram um período de 3 anos e 4 meses de diálogo persistente das organizações indígenas com a universidade, para a institucionalização do Curso de LEBI. Essa política institucional demonstra que ainda se mantém a "visão de mundo pautada na adequação social, impedindo e dificultando a transformação que poderia propiciar formas e relações mais democráticas" (NETO, 1993, p. 140). Desse modo, o Curso de LEBI surge em um contexto de mobilização organizacional indígena e superação de burocracia institucional, para concretização do direito de acesso à modalidade de ensino superior, com garantia das ênfases

\footnotetext{
${ }^{3}$ O NEIRO é uma organização indigenista, criada em 1992, formada por professores indígenas e não indígenas, por lideranças indígenas, professores da universidade, professores da SEDUC e de outras organizações.

${ }^{4}$ A OPIRON é uma organização indígena formada por professores.

${ }^{5}$ A Organização Indígena PADEREÉHJ representa os povos indígenas da Terra Indígena Igarapé Lourdes e Rio Branco, e visa promover a interlocução com os diversos segmentos da sociedade nacional e internacional, o desenvolvimento das atividades sociais e econômicas em caráter coletivo, a formação e informação dos povos, associações e lideranças, no sentido da construção da autonomia e da defesa do patrimônio ambiental, territorial e cultural, de acordo com os interesses e necessidades desses povos.

${ }^{6}$ A Universidade Federal de Rondônia, localizada em Porto Velho, possui 8 extensões nos municípios de Guajará-Mirim, Ariquemes, Ji-Paraná, Presidente Médici, Cacoal, Rolin de Moura, Vilhena e Porto Velho.

7 Conforme Regimento Interno (Resolução no 046/CONSEA, de 19 de junho de 2001), Art. $1^{\circ}$ - O Conselho Superior Acadêmico - CONSEA é órgão normativo, consultivo e deliberativo em matéria de ensino, pesquisa e extensão da Universidade Federal de Rondônia.
} 
no específico e intercultural. Ainda que controverso, em seu núcleo, este Curso pode ser considerada um marco político dentro da UNIR, uma vez que surge por mobilização de uma demanda legítima, levando-a a sair do marasmo habitual de pautas formativas abrangentes, genéricas, que mascaram a negligência de políticas públicas específicas.

A institucionalização do Curso de LEBI legitima a prática da interculturalidade dentro da universidade, uma vez que emerge no contexto das lutas contra os processos crescentes de exclusão social, ao propor novas estratégias de relação entre sujeitos e entre grupos diferentes, em meio ao reconhecimento das diferenças culturais, conforme Fleuri (2001).

\section{As expectativas das comunidades indígenas sobre o curso de licencia- tura em educação básica intercultural}

Até a Constituição de 1988, não existiam políticas destinadas à promoção da diversidade dentro do aparato estatal, sob prerrogativa da democracia racial e identidade nacional, uma forma estratégica para prática da ideologia homogeneizadora e integradora da sociedade. Para Grupioni (2006, p. 93),

Essa cultura burocrático-administrativa deve ser desconstruída e reconstruída para que se possam levar à frente os programas, projetos e ações que promovam o fortalecimento da diferença étnico-cultural nos três níveis administrativos autônomos (Federal, Estadual e Municipal), onde os três poderes da organização política (Legislativo, Executivo, Judiciário) tecem relações muitas vezes extremamente burocratizadas.

Nas últimas três décadas, uma das iniciativas pontuais que se tem destacado no reconhecimento da diversidade cultural diz respeito à promoção da educação escolar indígena, amplamente defendida por vários segmentos, tendo em vista que a relação entre os povos indígenas e a sociedade nacional vem adquirindo propriedade de diálogo intercultural, favorecido por meio da educação.

Se, por um lado, os motivos que levam o professor indígena à formação superior, na quase totalidade dos casos, estão arraigados na comunidade, assim como se observa na narrativa do acadêmico Puruborá, que afirma estudar "para buscar melhoria para o meu povo na educação, pois mesmo estando 
agora estudando nós não temos muitas oportunidades", por outro lado, a comunidade indígena também possui expectativas com a formação docente.

A escola hoje, atualmente, na minha concepção ela é um suporte, em busca de informação, em busca de conhecimento de todas as políticas públicas que se desenvolve no Brasil hoje, a escola é uma ferramenta que vem buscar esse conhecimento, ou além de buscar, leva também a divulgar nossos conhecimentos tradicionais né, isso faz com que a sociedade de fora valorize as comunidades indígenas. (Membro da comunidade Ikolen - Gavião).

Do ponto de vista da comunidade, a educação indígena, e, sobretudo a formação do professor, se apresenta como uma oportunidade de qualificação para representatividade indígena em demais campos políticos, como a saúde, a invasão de terras indígenas, a sustentabilidade, entre tantas outras necessidades derivadas do contato com o entorno regional, que se intensificam mediante a modernização do campo e da sociedade. Desse modo, a formação docente indígena representa a capacitação para o diálogo intercultural, em uma sociedade, em que:

A formação do cidadão como "sujeito de direito" somente é possível dentro do contexto e da escrita disciplinar e, neste caso, dentro do espaço de legalidade definido pela constituição. A função jurídico-política das constituições é, precisamente, inventar a cidadania, ou seja, criar um campo de identidades homogêneas que tornem viável o projeto moderno da governamentabilidade. (CASTRO-GÓMEZ, 2005, p. 80).

Assim, não apenas para as comunidades indígenas, mas também para a sociedade envolvente, o Curso de LEBI, ao promover o reconhecimento da especificidade cultural, qualifica o diálogo intercultural. Fleuri (2001) sugere que o termo ganhou força no Brasil a partir do reconhecimento da dominância de um modelo cultural em detrimento dos demais, o que resultou em processos de exclusão social que levaram à perda da identidade cultural.

Assim, além de um professor apto a oferecer ensino específico, diferenciado, bilíngue e intercultural, as comunidades indígenas esperam, desse 
profissional, o desenvolvimento de atividades políticas de ordem intercultural. Essas atividades ampliariam seu campo de formação para que seja capaz de, além do exercício da docência, conquistar modos do existir indígena em uma sociedade uniformizante.

\section{$5 \mathrm{O}$ acadêmico do curso Licenciatura em Educação Básica Intercultural}

Das “23 Terras Indígenas” (NEVES, 2012, p. 1) do Estado, 12 possuem representatividade no Curso de LEBI, por meio dos seus acadêmicos. São elas: Igarapé Laje, Igarapé Lourdes, Karitiana, Kaxarari, Kwazá, Pacaás Novos, Parque do Aripuanã, Rio Branco, Rio Guaporé, Rio Mequéns, Sagarana e Sete de Setembro, mais os representantes dos povos Migueleno e Puruborá, considerados povos ressurgidos, sem terra indígena no Estado. O curso conta, ainda, com representantes da Terra Indígena Zoró, do Estado do Mato Grosso, que faz divisa ao Sul de Rondônia.

Segundo dados levantados no ambiente de formação, 64\% dos acadêmicos são do sexo masculino e $36 \%$ do sexo feminino, divididos em 3 turmas, com 20 a 25 alunos cada; a primeira turma teve início no ano de 2010 e as demais, no ano de 2015. Os alunos da turma do ano de 2010 estão subdivididos conforme escolha do acadêmico, visto que o Curso propõe os 3 primeiros anos como Ciclo de Formação Básica, com habilitação para atuação no ensino fundamental, e os 2 últimos anos como Ciclo de Formação Específica, com habilitação em uma das 4 áreas de concentração: 1. Educação Escolar Intercultural no Ensino Fundamental e Gestão Escolar; 2. Ciências da Linguagem Intercultural; 3. Ciências da Natureza e da Matemática Intercultural; 4. Ciências da Sociedade Intercultural ${ }^{8}$.

Quanto à definição do perfil profissional docente indígena, os elaboradores do Projeto Pedagógico do Curso a percebem como precipitada, dada a complexidade da antecipação do "acabamento" de um consenso em construção, e elegem o conceito aberto do Curso, ao passo em que anunciam que se trata de uma ação coletiva, em que os próprios alunos indígenas ajudarão a elaborar o perfil. Demonstra-se, assim, em tese, a superação da imposição de modelo, para a elaboração conjunta da profissionalidade docente indígena.

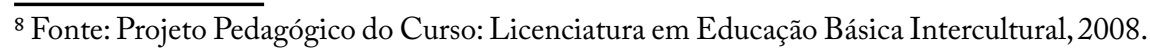


No que se refere aos contornos do perfil docente indígena, pode ser observada, entre os acadêmicos, a ênfase atribuída à cultura como condição anterior à formação profissional indígena, uma vez que sua gênese delibera o professor indígena. $\mathrm{O}$ que, por sua vez, faz com que essa atividade não se esgote em âmbito da sala de aula. Segundo Luciano (2006), a cultura indígena se refere ao modo de ver e de se situar no mundo, como forma de organizar a vida social, política, econômica e espiritual de cada povo.

Tal referência se confirma quando, perguntado aos acadêmicos se, caso pudessem trocar de curso, qual escolheriam, e 27\% afirmaram que não trocariam de curso. Dentre os outros, os cursos mais desejados foram Direito (18\%), Enfermagem (15\%) e Pedagogia (7\%), o que corresponde às demandas antigas e relevantes das comunidades indígenas: amparo jurídico, saúde e educação. Os dados totalizados podem ser vistos no quadro demonstrativo (Figura 1).

Figura 1 - Gráfico demonstrativo de intensão de curso dos acadêmicos do Curso de Licenciatura em Educação Básica Intercultural - ano 2016

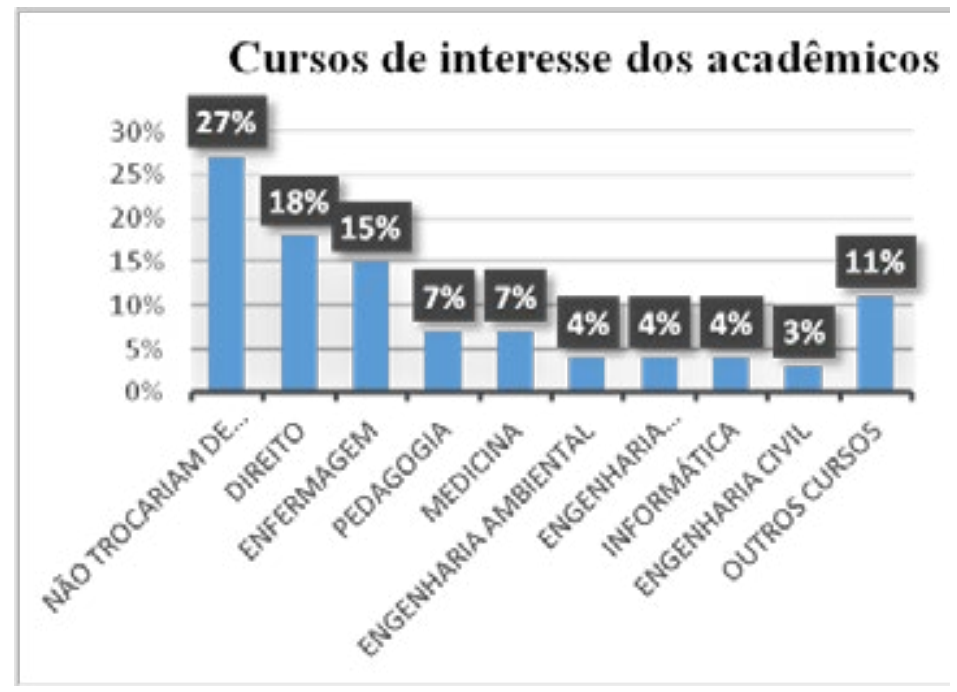

Fonte: Elaborado pela Autora (2016)

Para os acadêmicos indígenas, a educação deve ser priorizada, pois ela subsidia todas as causas indígenas. A educação tem função pré-estabelecida 
de defesa da comunidade, da cidadania, até então garantida por meio de parca legislação, pelos movimentos indígenas e indigenistas. Nesse sentido, o conhecimento ocidental é tão importante para a luta por novos direitos, como para a garantia de direitos já conquistados, uma vez que tais direitos resultam do reconhecimento das especificidades culturais e sociais dos diferentes povos indígenas.

Assim como as intenções na escolha dos cursos, as pretensões após a formação revelam que, entre os acadêmicos que desejam exercer a docência e dar continuidade à formação, encontram-se aqueles que desejam trabalhar para a comunidade, como ato intrínseco da formação. Esses formandos dispõem-se a servir "frequentemente, como um dos mediadores nas relações interétnicas estabelecidas com a sociedade nacional" (GRIPIONI, 2006, p. 81).

Figura 2 - Gráfico demonstrativo de pretensão profissional dos acadêmicos após a formação do Curso de Licenciatura em Educação Básica Intercultural - ano 2016

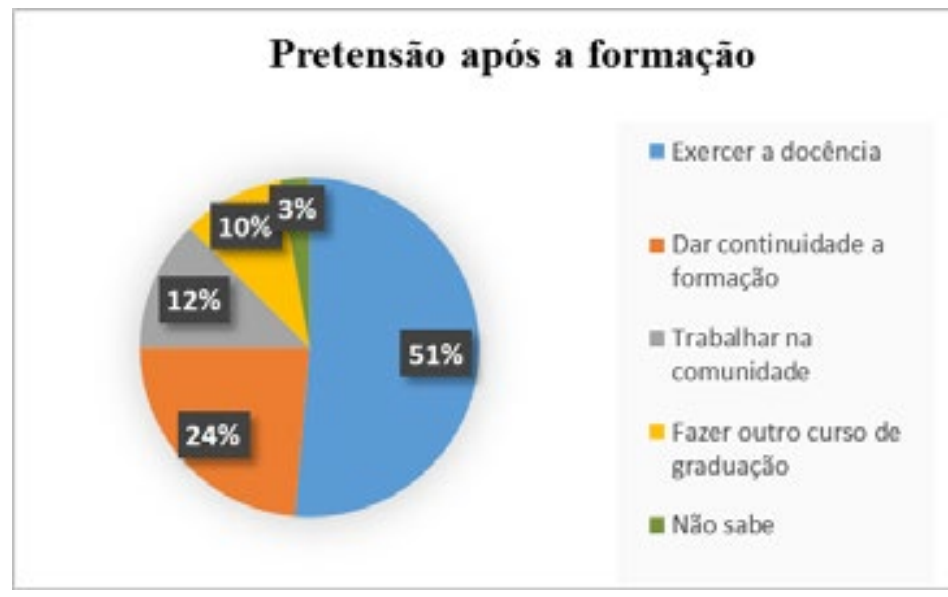

Fonte: Elaborado pela Autora (2016)

Para a maioria dos povos indígenas, a formação em licenciatura intercultural também qualifica o professor à representação comunitária, pelo entendimento de que o conhecimento que o professor indígena desenvolveu o habilita "mais" do que os demais integrantes da comunidade para 
representar o povo em situações interétnicas. Esse quadro tem favorecido a predominância do entendimento do Curso de LEBI, como significativa ferramenta de reposicionamento cultural nas instâncias político e social. Assim,

O seu perfil docente é um misto de diferentes desejos, significados e expectativas que, de alguma forma, sintetizam aquilo que a comunidade educativa considera adequado para esse novo profissional. (SECCHI, 2005, p. 54)

Conciliar a demanda comunitária indígena à formação não tem se revelado uma tarefa fácil para o núcleo acadêmico. Mas cabe à universidade, mediante o perfil profissional docente indígena que se apresenta, mediar as demandas culturais, como requisito de formação, sem, no entanto, perder de vista que "a escola indígena não pode ter como função primordial a resolução de problemas às identidades, às tradições, às culturas e aos saberes indígenas" (LUCIANO, 2013, p. 126), mas precisa ter qualidade e competência para promover os conhecimentos ocidentais desejados como função principal.

Os povos indígenas, na atualidade, reivindicam e recebem a escola, por reconhecer nela o veículo que favorece a compreensão do contexto comunitário, imerso no sistema político social nacional.

\section{Considerações Finais}

A criação do Curso de Licenciatura em Educação Básica Intercultural evoca a superação da colonialidade do poder e do saber, historicamente presente no estado, que utiliza a escola como homogeneizadora de um padrão cultural, que não permite florescer a cultura em suas formas próprias de conhecimento. Nas palavras de Quijano (1992, p. 72), que "bloqueia a capacidade de autoprodução e autoexpressão cultural, já que pressiona para a imitação e a reprodução”.

O Curso de LEBI é a materialização do diálogo intercultural, proposto por meio das organizações dos povos indígenas do estado junto a 
Universidade Federal de Rondônia, pelo reconhecimento do direito à educação diferenciada, específica e intercultural em nível superior, insurgindo para um novo delineamento das relações étnico-raciais que reconhece as diferenças culturais para a promoção de novas relações.

O processo histórico de colonização do estado de Rondônia evidencia nos âmbitos político, educacional e social a urgência da formação docente indígena, necessária para o empoderamento representativo, o diálogo intercultural, luta por direitos, visibilidade de indenidade e resistência a integração cultural massificada.

Dessa forma, pode-se dizer que os povos indígenas de Rondônia vêm reelaborando suas identidades étnicas ao longo de todo o processo histórico do estado, e agora projetam o futuro das comunidades com base na formação docente indígena em nível superior, específica, bilíngue e intercultural.

\section{Referências}

ANDRÉ, Marli Eliza Dalmazo Afonso. Etnografia da prática escolar. Campinas: Papirus, 1995.

CASTRO-GÓMEZ, Santiago. Ciências sociais, violência epistêmica e o problema da "invenção do outro". In: LANDER, Edgardo. (Org.). A colonialidade do saber: eurocentrismo e ciências sociais. Perspectivas latino-americanas. Buenos Aires: Clacso, 2005.

ESCOBAR, Arturo. O lugar da natureza e a natureza do lugar: globalização ou pós-desenvolvimento? In: LANDER, Edgardo. (Org.). A colonialidade do saber: eurocentrismo e ciências sociais. Perspectivas latino-americanas. Buenos Aires: Clacso, 2005.

FLEURI, Reinaldo Matias. Desafios à educação intercultural no Brasil. Revista PerCursos, UDESC/FAED, Florianópolis, n. 1,2001.

GRIPIONI, Luís Donisete Benzi. (Org.). Formação de professores indígenas: repensando trajetórias. Brasília: Edições MEC/UNESCO, 2006.

LANDER, Edgardo. Ciências Sociais: saberes coloniais e eurocêntricos. In: LANDER, Edgardo. (Org.). A colonialidade do saber: eurocentrismo e ciências sociais. Perspectivas latino-americanas. Buenos Aires: Clacso, 2005.

LUCIANO, Gersem dos Santos. Educação para o manejo do mundo: entre a escola ideal e a escola real no Alto Rio Negro. Rio de Janeiro: Contra Capa; Laced, 2013. 
LUCIANO, Gersem dos Santos. O Índio Brasileiro: o que você precisa saber sobre os povos indígenas no Brasil de hoje. Brasília: Ministério da Educação, Secretaria de Educação Continuada, Alfabetização e Diversidade; LACED/Museu Nacional, 2006.

MATIAS, Francisco. Pioneiros. Porto Velho, RO: Gráfica e Editora Maia Ltda., 1998.

MORENO, Alejandro. Superar a exclusão, conquistar a equidade: reformas, políticas e capacidades no âmbito social. In: LANDER, Edgardo. (Org). A colonialidade do saber: eurocentrismo e ciências sociais. Perspectivas latino-americanas. Buenos Aires: Clacso, 2005.

NETO, Clementino Leite. Fatores políticos condicionantes da criação e desenvolvimento de universidades brasileiras: o caso da universidade federal de Rondônia. 1993. 196 f. Dissertação (Mestrado em Administração Pública) - Fundação Getúlio Vargas. Escola Brasileira de Administração Pública. Rio de Janeiro: FGV/EBAP, 1993.

NEVES, Josélia Gomes. A UNIR e os Povos Indígenas de Rondônia: a invisibilidade do tema nas pautas dos reitoráveis na eleição 2012. Tudo Rondônia, Porto Velho, 27.02.2012. Disponível em: <http://www.tudorondonia.com.br/noticias/a-unir-e-os-povos-indigenas-de-rondonia-a-invisibilidade-do-tema-nas-pautas-dos-reitoraveis-na-eleicao-2012-,26907.shtml>. Acessado em: 30 out. 2015.

PERDIGÃO, Francinete; BASSEGIO, Luiz. Migrantes Amazônico Rondônia: A trajetória da ilusão. São Paulo: Edições Loyola, 1992.

PORTO-GONÇALVES, Carlos Walter; QUENTAL, Pedro de Araújo. Colonialidade do poder e os desafios da integração regional na América Latina. Pólis Revista Latinoamericana, Universidad de Los Lagos Campus Santiago, n. 31, 2012.

PPC. Projeto Pedagógico do Curso: Licenciatura em Educação Básica Intercultural. Universidade Federal de Rondônia. Campus de Ji-Paraná, 2008.

QUIJANO, Aníbal. Colonialidade, poder, globalização e democracia. Revista Novos Rumos, UNESP, Marília, Ano 17, n. 37, 2002. Disponível em: <http://plataformacomum. com.br/iap/index.php?option=com_docman\&task=cat_view\&gid=42\&Itemid=46\&limit start=10 >. Acessado em: 10 jul. 2015.

QUIJANO, Aníbal. Notas sobre a questão da identidade e nação no Peru. Revista Estudos Avançados, USP, São Paulo, v. 6, n. 16, set./dez.1992. Disponível em: <http://www.scielo. br/pdf/ea/v6n16/v6n16a07.pdf>. Acessado em: 3 mar. 2016.

SECCHI, Darci. Avaliador externo. Relatório da 2a Avaliação Externa. 2005. In: Relatório Final $3^{\circ}$ Grau Indígena. Turma 2001-2006. Volume II. Universidade do Estado de Mato Grosso (UNEMAT) - Barra do Bugres. Projeto de Formação de Professores Indígenas. Barra do Bugres: UNEMAT, 2006.

VENERE, Mario Roberto. PROJETO AÇAÍ: uma contribuição à formação dos professores indígenas no Estado de Rondônia. Tese (Doutorado). 2011. UNIVERSIDADE ESTADUAL PAULISTA “JÚLIO DE MESQUITA FILHO”. Faculdade de Ciências e Letras - Campus de Araraquara - SP, 2011. 


\title{
10. O EU E O OUTRO: A TEMÁTICA INDÍGENA NA ESCOLAE A PERCEPÇÃO DE ALUNOSE PROFESSORES
}

\author{
Neide da Silva Campos (COEDUC/PPGE/UFMT) \\ Suzana Helena Alves de Arruda (SEDUC-MT) \\ Maria Angela de Arruda Bastos (SEDUC-MT) \\ Beleni Saléte Grando (COEDUC/PPGE/UFMT)
}

\section{Introdução}

Nem parece indio! Para que indio quer tanta terra? Até quando vamos pagar essa divida histórica? São uns preguiçosos, dependentes do governo! Vivem melhores do que nós! Eles possuem celular, filmadora, carrões! Essas narrativas foram ouvidas em diversos momentos, vozes e ecos de alunos, e de professores de uma escola estadual no município de Poconé, Mato Grosso, a partir da implementação da Lei 11.645/08. Assim, conforme os autores Grando; Stroher, Campos (2020):

O estudo sobre o Outro nos permite olhar para dentro e nos enxergar enquanto produto de uma sociedade preconceituosa e autoritária, desnudando-se e se reconhecendo preconceituoso, um processo doloroso tanto para professores quanto para os estudantes, pois implica em romper com crenças fortemente consolidadas no sistema escolar, na família, nos meios de comunicação, na sociedade na qual nos inserimos. (GRANDO; STROHER, CAMPOS, 2020, p.234)

Os estereótipos e estigmas que permeiam os povos indígenas, muitas vezes replicados nos discursos, evidenciam o quão pouco sabemos sobre os diferentes povos e a necessidade de efetivar práticas pedagógicas sobre a história e cultura dos povos indígenas: "As contradições e os preconceitos 
têm na ignorância e no desconhecimento sobre o mundo indígena suas principais causas e origens e que precisam ser rapidamente superados". (BANIWA, 2006, p. 35).

Como outras legislações voltadas ao reconhecimento das identidades na escola, a Lei 11.645/08 nasce de uma demanda social por respeito, valorização, conhecimento e reconhecimento tanto no que se refere à população negra, como à população indígena, cujo histórico é de invisibilidade e negação no espaço escolar. Tematizar sobre as questões indígenas na escola, numa sociedade preconceituosa, é buscar minimizar tais práticas, sensibilizar o outro para as diferentes culturas em relação, numa postura de quem, a partir da educação escolar, busca construir uma sociedade mais humana em relação ao outro.

Como proposta de implementação da lei 11.645/08, o Grupo de Pesquisa Corpo, Educação e Cultura (COEDUC/UFMT) vincula à prática pedagógica na formação continuada de professores, cujo recorte temático é a história e a cultura dos povos indígenas, realizada em parceria com o Centro de Formação e Atualização dos Profissionais da Educação Básica (Cefapro/Cuiabá) para os professores da rede estadual de ensino. Neste texto, trazemos dados e discussões que resultaram da pesquisa exploratória realizada em uma escola, na cidade de Poconé-MT, no ano de 2013, no período de agosto a novembro, durante a execução do Projeto "O eu e o outro: novos olhares sobre os povos indígenas do Brasil".

Além dos estudos em sala de aula, uma das etapas foi a participação de alunos e professores nos XII Jogos dos Povos Indígenas que ocorreu em novembro de 2013, na cidade de Cuiabá-MT, com a presença de mais de 1.500 indígenas de diversas regiões do Brasil, bem como indígenas de outros países, entre eles: Peru, Argentina, Equador, Paraguai, México, Canadá, Guiana Francesa e Costa Rica. Conforme, Grando, Stroher e Campos (2020):

Durante a realização dos XII Jogos dos Povos Indígenas, os estudantes e professores foram recebidos por representantes da etnia estudada, e acompanhados por pesquisadores do Coeduc, a fim de conhecermos quais estratégias pedagógicas e mediações interculturais potencializavam a educação intercultural pretendida na formação. (2020, p.231). 
Os sujeitos da pesquisa foram os professores e os alunos, com os quais buscamos compreender suas concepções a respeito da temática indígena. Utilizamos como instrumento de pesquisa questionário aberto dirigido aos professores, assim como observação de campo. Os dados apontam que ainda há muito preconceito em relação à temática indígena entre os alunos e professores, o que fica evidente quando se observam diferentes formações escolares e idades, ou experiências socioculturais, que fazem a cultura escolar e da sociedade poconeana, no Pantanal Mato Grossense.

Observamos que a implementação da Lei 11.645/08, principalmente no que tange às questões indígenas, ainda é incipiente no contexto escolar, $o$ que nos levou a buscar melhor compreender o papel da formação de professores. Ao refletir sobre a formação inicial de professores, identificamos que ainda não há formalmente a inclusão de disciplina ou conteúdo curricular que dê conta da formação crítica da história e cultura dos povos nativos do Brasil. Isso demonstra uma fragilidade/lacuna no currículo educacional sobre formação inicial a esse respeito, o que nos leva a pensar sobre o quão necessária e urgente é a criação de políticas públicas que atendam de fato a uma demanda enorme, voltada à formação adequada e contínua, pautada nas diversidades, no reconhecimento e no conhecimento sobre as histórias e as culturas dos mais de 300 povos indígenas.

\section{Os professores e a temática indígena: desvelando os preconceitos}

Trabalhar as questões indígenas no interior das escolas é uma necessidade urgente perante as inquietações provocadas pela implementação da Lei 11.645/08. Nesse sentido, ao problematizar essa temática no chão da escola, emerge uma série de questões que antes eram ignoradas pela comunidade escolar. O diálogo sobre as diferentes etnias contribui para amenizar os pensamentos preconceituosos, e nos remete a outra questão crítica: pouco ou quase nada sabemos sobre os indígenas. Esses elementos foram revelados pela prática cotidiana no período de execução do projeto "O eu e o outro: novos olhares para povos indígenas do Brasil".

Em entrevista sobre a implementação da temática indígena nas escolas do Brasil, o antropólogo Luis Donisete Benzi Grupioni destaca que: 
De modo geral eu diria que se sabe pouco e se conhece mal a história e os modos de vida dos povos indígenas que vivem no Brasil. A situação já foi pior, e inúmeros avanços podem ser contabilizados nos últimos anos em termos de difusão de uma nova imagem sobre os povos indígenas que ultrapasse a caricatural cena de índios nus, vivendo em harmonia com a natureza, no culto a Tupã e Jaci, pescando e caçando com arcos e flechas. Mas ainda estamos distante de um cenário em que os povos indígenas possam ser respeitados em sua integridade, reconhecidos como coletividades conscientes e capazes de dizerem o que querem de seu futuro. $\mathrm{E}$ isso tem relação direta com a falta de informação sobre esses povos, seja em termos do processo histórico, no qual grassaram políticas adversas a eles dirigidas, seja em termos contemporâneos (GRUPIONI, 2006, p.2).

Ao retornarmos para a escola, após a formação, foi elaborado um projeto sobre a história e cultura do povo Kuikuro do Alto Xingu. Estudar um determinado povo, proposta do curso $^{1}$, nesse momento, contribuiu para que pudéssemos conhecer mais sobre essa etnia, até então desconhecida por nós da escola, em relação à sua cultura, sua língua, suas pinturas corporais e seus mitos. E, desse olhar atento à especificidade do povo Kuikuro, começamos a ver as diferenças, a reconhecer as singularidades, nos permitimos conhecer mais profundamente sobre o outro. Desenvolver um projeto de ação com o estudo de uma determinada etnia que estaria participando dos XII Jogos dos Povos Indígenas era uma das propostas do curso de formação.

Em reunião com a comunidade escolar, apresentamos aos profissionais da educação a proposta do projeto e sua finalidade, deixando livre para ajustes e contribuições das partes envolvidas. Embora instigássemos para sugestões, acrescentar ou retirar algo do projeto, inicialmente houve

\footnotetext{
${ }^{1}$ Em 2013, foi proposto que cada escola, escolhesse uma etnia do estado de Mato Grosso e que participaria do XII Jogos dos Povos Indígenas para estudo aprofundado. Atualmente o Coeduc tem centrado as formações em Cuiabá-MT, a partir da Etnia Bororo, já que: "Para discutirmos as relações étnico - raciais em Mato Grosso, a partir da história e cultura do que hoje conhecemos como a cidade Cuiabá na qual vivemos, o trabalho inicia com o reconhecimento que não se estuda a história descolada do sentido que esta faz para a compreensão do momento atual, pois a opção por estudar o Povo Bororo implica diretamente no fato de estarmos vivendo e sendo influenciados cotidianamente pela territorialidade ancestral deste povo originário".(GRANDO; PINHO; RODRIGUES, 2018, p.88)
} 
um "sonoro" silêncio. Ali, reunidos, no silêncio gritante de todos, cerca de cinco minutos, os professores se entreolhavam sem nada dizer verbalmente, porém corporalmente pareciam incomodados com o projeto.

A escola sempre teve dificuldade em lidar com a pluralidade e a diferença. Tende a silenciá-las e neutralizá-las. Sente-se mais confortável com a homogeneização e a padronização. No entanto, abrir espaços para a diversidade, a diferença e para o cruzamento de culturas constitui o grande desafio que está chamada a enfrentar (MOREIRA; CANDAU, 2003, p.161).

Passado o impacto inicial, as primeiras sugestões de propostas começaram a surgir. Uns se mostravam empolgados com a possibilidade de trabalhar a temática indígena, enquanto, para outros, o projeto era mais uma demanda desnecessária frente às tantas responsabilidades da escola.

Foi solicitado que respondessem um questionário aberto para que pudéssemos saber os conhecimentos dos professores a respeito dos indígenas. Dos 16 professores, 10 responderam o questionário. Uma das questões versava sobre o conhecimento das etnias indígenas, e seis professores não responderam essa questão. Dos professores que responderam, observamos que foram poucas as etnias mencionadas, a citar: Guarani, Pataxó, Xavante, Enawene-Nawe, Cinta Larga e Kuikuro.

Isso evidencia o pouco conhecimento que temos sobre as diferentes etnias, considerando a realidade brasileira com várias etnias espalhadas pelo Brasil, bem como o Estado de Mato Grosso, que possui em seu território mais de 40 etnias indígenas. $\mathrm{O}$ conhecimento sobre as diferentes etnias nos permite avançar na questão sobre o que vimos defendendo: os indígenas não são todos iguais; cada etnia possui especificidades e formas de organizar e ser no mundo [grifo nosso].

O fato de não conhecer a realidade indígena de nossa sociedade, torna-se cada dia mais evidente, por que muitas vezes a escola acaba deixando de estudar a diferença. Diferença que, neste caso, é tratada como um desafio dentro dos meios escolares e não como uma necessidade [...] (VIERA, 2008, p. 71). 
$\mathrm{Na}$ questão "O que você sabe/conhece sobre os indígenas?”, observamos ainda o conhecimento superficial que temos sobre a história e cultura dos povos indígenas, visto que muitas repostas limitaram-se a informar que os índios foram os primeiros habitantes do Brasil, o que é quase um grande chavão, e que os indígenas possuem culturas diferentes. Mas, quando relacionados à questão do conhecimento das etnias, são observados poucos. Posto isso, refletimos sobre o que verdadeiramente sabemos sobre as diferentes culturas indígenas, suas pinturas, suas danças, seus jogos, seus ritos e mitos, seus conflitos...

Aos indagarmos sobre o que é ser indígena para os professores, há educadores que mantêm uma visão ainda estigmatizada do ser indígena daquele que vive na floresta, que sobrevive da caça e da pesca, imprimindo, assim, uma visão do índio primitivo. Isso nos permite refletir sobre os cinco mitos descritos por Freire (2010) sobre os indígenas. O terceiro diz respeito ao fato de se pensar que as culturas indígenas são congeladas, envolvendo a imagem que permeia o imaginário da sociedade sobre o indígena "nu ou de tanga, no meio da floresta, com arco e flecha como foi descrita por Pero Vaz de Caminha (FREIRE, 2010, p. 24).

Os dados revelam também um preconceito subjacente, velado, de que há uma cultura superior, já que, para um educador, os indígenas “[...] estão evoluindo cada vez mais seus conhecimentos, portanto, são seres humanos" (grifamos). Essa postura evidencia o segundo equívoco descrito por Freire (2010): acreditar que os indígenas possuem culturas atrasadas.

Outro dado que desvela o preconceito ocorreu quando retornamos dos XII jogos e ouvimos de uma profissional da educação que, no evento, "tinha mais índio, do que gente", discurso que insere o índio numa outra posição, e que fazer parte da sociedade envolvente confere aos não indígenas uma outra categoria (superior) de ser e estar no mundo. Assim, de acordo com Brand (2002), "não basta, portanto, levar o educando [educador] a perceber a existência do outro, culturalmente distinto. É necessária uma nova postura diante do outro" (p.148). Eis aqui um ponto nevrálgico: como formar alunos sensíveis ao diferente, se o ator desse processo que visa levar o conhecimento, o esclarecimento, e fazer com que o educando 
rompa o senso comum, não está desprovido dos pré-conceitos com relação aos indígenas?!

Isso também nos remete ao momento em que a professora Severiá, mestranda em educação, da etnia Karajá e Javaé, foi à nossa escola ministrar uma palestra. Em alguns momentos, nos pareceu que a palestrante não tinha nome, etnia, origem, era apenas denominada como índia; teríamos na escola uma palestrante indígena da etnia Karaja e Javaé, professora, mãe de uma menina, e que foi denominada por todos apenas como a "professora índia”. Em alguns momentos, a empolgação era tanta em receber uma palestrante indígena que as pessoas se referiam a ela acrescentando o famoso "uh-uh-uh-uh-uh", batendo a palma da mão na boca.

Quando a professora Severiá chegou à escola, os nossos olhos corriam curiosos buscando as diferenças, o cabelo, o jeito de andar, de falar. No passeio mostrando a escola, os alunos gritavam de suas salas "Olha lá, a professora índia! A índia chegou!", parecia que estavam diante de um ser exótico.

Em relação a de que forma os professores poderiam aprender mais sobre os indígenas, os dados nos revelam que a questão sobre a formação, estudos e capacitação é essencial para o desenvolvimento de uma prática que atende a Lei 11.645/08. A vinda da professora Severiá na escola e sua formação com os professores, e na palestra que houve com os alunos do $9^{a}$ ano, contribuiu de forma significativa para superar algumas visões de senso comum e alguns pensamentos postos pelas mídias e incorporados como verdades para os jovens alunos.

\section{A percepção dos alunos sobre os povos indígenas}

A escola tem uma função primordial ao trazer para o cotidiano a questão da diversidade. Nesse espaço de tantas diferenças, falar sobre o outro, o diferente, é um meio de potencializar e discutir, bem como olhar o outro com outras lentes, não com a que estamos acostumados a lidar cotidianamente, isto é, a lente do preconceito.

Um desses momentos - o de como a criança percebe o outro - ocorreu na hora do almoço com os alunos do Projeto mais Educação. Uma 
aluna questiona a coordenadora do Projeto Mais Educação sobre a "professora índia" que estaria na escola. A coordenadora responde à aluna que a Professora já estava ali, se referindo e apontando a pessoa que almoçava ao lado. A aluna olha, mas não vê. Ali, quase lado a lado, para a aluna, a indígena não se enquadrava no seu conceito de ser índio e indaga perplexa por mais três vezes “cadê a índia?!". Obtendo a mesma resposta, a decepção da aluna foi visível. Aos olhos da menina, a nossa convidada, que trajava roupa, falava o nosso bom português, não se parecia com a imagem produzida, principalmente estereotipada nos livros didáticos, do ser indígena.

A seguir temos o relato de uma professora de Língua Portuguesa, com os alunos do $9^{\circ}$ ano, sobre a experiência vivenciada durante a execução do projeto, que mostra os processos pelos quais os alunos e a professora puderam ressignificar seus olhares sobre os indígenas.

Foi muito prazeroso tanto para os alunos quanto para mim enquanto professora desta turma, receber a professora Severiá, na nossa sala de aula. Foi uma experiência belíssima e inspiradora e conhecimento inesquecivel à cultura indígena. Naquela manhã foi nitido o olhar de ansiedade dos adolescentes em receber uma Indigena na escola. Eles esperavam uma jovem, vestida a caráter, com arco e flecha, é tudo que a maioria das pessoas pensam sobre os indios "o selvagem, que anda nu ou quase nu". Para a decep̧̧ão de alguns, a Severiá se mostrou o oposto do que eles imaginaram. Porém essa decep̧ão deu lugar a um bombardeio de perguntas que minutos depois tornou-se em uma agradável conversa. Todos queriam saber como era a vida na aldeia, como vestiam, o que comiam, o relacionamento familiar, namoro, casamento, linguagem, tudo sobre os indígenas. [...] Após essa experiência ficamos motivados a estudar mais sobre os indios e nada melhor que uma aula de campo. Assim, fomos assistir aos jogos indigenas na arena sucuri, em Cuiabá, onde tivemos contato com milhares de indios de diversas etnias, diferentes culturas e idiomas. Ficamos maravilhados, todos querendo registrar os melhores momentos com fotos e videos das etnias que encontravam. Passamos o dia num intenso calor que tornou-se pequeno diante do conhecimento que tivemos. $E$, aquele conceito do que indios são, é diferentes, foi quebrado dando espaço ao novo conceito "indio são gente com direitos e deveres, logo devem ser respeitado". Não vou dizer que esse conceito se generalizou na escola Caetano, 
mas boa parte do corpo discente e um pequeno grupo docente se sensibilizou para concluir esse trabalho. Montamos uma exposição com as fotos e vídeos registradas pelos alunos interagindo com os indios de diversas etnias nos jogos indígenas cuja temática foi "Uma viagem inesquecivel", com imagens do indio real que ficou registrado em nossas memórias. (Profa. A),

Os dados com os alunos do $2^{\circ}$ ano, $1^{\circ}$ Ciclo, ao trabalhar a temática indígena com alunos de 7 (sete) e 8 (oito) anos, o modo de pensar o indígena, também já revela a carga de preconceito. Muitos enfatizavam que tinham medo, que os índios comem as pessoas, que matam.

Num cenário marcado por desinformação e intolerância, é urgente divulgar informações corretas e atualizadas sobre esses povos. É urgente criar estratégias para que nossos alunos possam rever valores e atitudes frente aqueles que são diferentes de nós, pois se não houver um movimento de abertura ao outro, ao diferente, ao novo, pouco poderá ser conquistado nesse terreno. (GRUPIONI, 2006, p. 2)

“Os índios vão vir para cá, vão tomar tudo”. "Eu não gosto de índio”. Ao questionar o aluno sobre o porquê de não se gostar de índio, ele enfatizou que era porque os índios matavam os animais para comer. Todas essas questões foram poblematizadas junto aos estudantes no sentido de contribuir para que pudessem ter uma outra perspectiva dos fatos superando a visão limitada, ofuscada e equivocada da realidade histórica, quando se trata de debater sobre os indígenas na escola.

O preconceito traduz a falta de flexibilidade entre os grupos, ajudando a definir o posicionamento de um sujeito social frente ao outro. Acrescentando aos modelos conceituais rigidamente definidos sobre o outro (estereótipos) uma forte conotação emocional e afetiva, o preconceito tende a absolutizar determinados valores que se transformam em fonte de negação da alteridade (FLEURI, 2006, p. 499).

Observamos, nas narrativas dos alunos na faixa etária de 7 (sete) e 8 (oito) anos, que o índio é visto por eles sempre do ponto de vista negativo (come o outro, mata, invade, pega as crianças). No imaginário das crianças, o 
indígena aparece sempre como algo que produz algum mal, e trabalhar com a temática indígena, quando há toda essa carga preconceituosa, não pode ser um trabalho que acontece esporadicamente, mas sim cotidianamente, para que, de fato, possa provocar mudanças substanciais e de comportamento com relação ao outro.

Quando retornou dos XII Jogos dos povos indígenas, a professora alfabetizadora estava com os braços tatuados com algumas pinturas corporais indígenas e com alguns colares. Os alunos dela, ao observarem-na com as pinturas e colares, se dirigiam a ela como a "professora índia". A professora provoca as crianças a pensarem que ela não "virou" indígena por utilizar tais ornamentos, assim como o fato de os indígenas usarem celular, roupas, carros, ou viverem na cidade não os tornam não indígenas.

Trata-se de provocar os alunos nesta perspectiva contribui para pensar numa outra dimensão maior, uma vez que, quando os indígenas vêm para a cidade, ou aqueles que vivem na cidade são classificados como não sendo mais indígenas ou o clássico "nem parece índio!", tão fortes são os estereótipos e marcas para definir se é ou não indígena no imaginário da sociedade envolvente. Outro fator a pontuar é que, ao visitarmos as aldeias indígenas, não nos tornamos indígenas, mas quando os indígenas vêm para cidade, é quase que imediata a desqualificação e não valorização dele em torno de sua identidade. A quem interessa esse discurso e quais suas implicações no nosso cotidiano?

A luta contra os estereótipos e os processos discriminatórios, assim como a defesa da igualdade de oportunidades e o respeito às diferenças não é um movimento simples, pois os mesmos argumentos desenvolvidos para defender relações mais justas, dependendo do contexto e do jogo político em que se inserem, podem ser ressignificadas para legitimar processos de sujeição e exclusão (FLEURI, 2006, p. 499).

Assim, observamos que a criança também traz consigo muitas visões preconceituosas, visões estas que são produzidas nos espaços de convívio social. E silenciar isso no espaço escolar é concordar também com essas perspectivas. Nesse sentido, a escola, ao trabalhar com a Lei 11.645/08, pode promover outras formas de ver os indígenas, contribuindo, assim, para relações humanas mais sensíveis ao outro. 
Negar o diálogo dessa diversidade, que é tão marcante no Brasil e principalmente em Mato Grosso, é negar a nossa própria identidade, bem como assumir uma postura passiva frente a tantos estigmas e preconceitos atualmente sobre os indígenas.

\section{Considerações finais}

A Lei 11. 645/2008, por si só, não garante a efetivação da sua aplicabilidade. A sua promoção no contexto escolar, pautada na diferença e para as diversidades, constitui uma ação de cada um e cada uma no chão da escola, na necessidade de uma educação mais humana e sensível às diferenças. Para isso, é necessário fazer as indagações sobre o que nós, como educadores, sabemos a respeito das questões indígenas, quais preconceitos produzimos e reproduzimos nas nossas práticas.

Para implementação de práticas exitosas referentes à Lei 11.645/08, torna-se necessária e urgente a formação continuada de educadores, pois, conforme foi analisado pelos dados e pela observação no transcorrer da execução do projeto, precisamos ampliar o conhecimento sobre as questões indígenas. Foi verificado que o que sabemos sobre as diferentes etnias é um conhecimento superficial e limitado, quando muito carregado de preconceito; outrossim, ainda falta aos educadores reconhecerem que são preconceituosos em relação aos povos indígena, pelo fato do desconhecimento a respeito desse grupo étnico. A vivência e o contato com as diferentes etnias também é um fator essencial para que possamos pensar em outro tipo de educação que valorize e respeito o outro.

Cabe considerar que a práxis pedagógica, referente ao estudo da cultura e história dos povos indígenas, deve ser contínua e não pontual, pois desnaturalizar todo um processo historica e culturalmente produzido sobre o outro requer um movimento cíclico de retomada dessas questões emergentes no chão da escola. O diálogo constante e o que podemos aprender sobre os indígenas nas diferentes áreas de conhecimento podem contribuir para avançarmos numa educação que promova o pensamento crítico sobre as diferenças. 


\section{Referências}

BANIWA, Gersem dos Santos Luciano. O índio brasileiro: o que você precisa saber sobre os povos indígenas no Brasil de hoje. Brasília: MEC/SECAD; LACED/Museu Nacional, 2006.

BRAND, Antônio Jacó. Os desafios da interculturalidade e a educação infantil. In: MUÑOZ CRUZ, Héctor. (Org.) Rumbo a la Interculturalidad en educación. México: UAM, 2002. p. 139-158.

FLEURI, Reinaldo Matias. Políticas da diferença: para além dos estereótipos na prática educacional. In: Educação e Sociedade/CEDES. v.27, n.95. Campinas: Cedes, 2006. p. 495-520.

FREIRE, José Ribamar Bessa. A herança cultural indígena, ou cinco ideias equivocadas sobre os índios. In: ARAUJO, Ana Carvalho Ziller de. Cineastas indígenas: um outro olhar - guias para professores e alunos. Olinda: Vídeos nas aldeias, 2010. p. 15-33.

GRANDO, Beleni Saléte; PINHO, Vilma Aparecida de; RODRIGUES, Eglen Silvia Pipi Rodrigues. Metodologia intercultural na formação-ação para a educação infantil: a cultura bororo e as relações étnico-raciais. In: Laplage em Revista. Sorocaba, v.4, n. especial, set. - dez. 2018, p. 86-101. Disponível em: https://www.laplageemrevista.ufscar.br/index.php/ lpg/article/view/587/826. Acesso: 25 fev. 2020.

GRANDO, Beleni Saléte; STROHER, Jonathan; CAMPOS, Neide da Silva. Por que estudar a história e cultura indígena nas escolas? Contribuições da formação-ação-intercultural do Coeduc em Mato Grosso. In: Educazione Aperta. n.7, 2020. p.223-241. Disponível em: http://educazioneaperta.it/archives/2819. Acesso: 4 set. 2020

GRUPIONI, Luis Donisete Benzi. Lei 11.645/08 na escola. In: Guia Prático para Professores de Ensino Fundamental 1, publicação mensal da Editora Lua (entrevista do mês da edição de abril de 2009. Ano 06, n. 62). p. 1-6.

MOREIRA, Antônio Flavio; CANDAU, Vera Maria. Educação escolar e cultura/s: construindo caminhos. In: Revista Brasileira de Educação, n.23, maio/jun./jul./ago. 2003. p. 156-168.

VIEIRA, Carlos Magno Naglis. O que interessa saber de índio? Um estudo a partir de manifestações alunos de escolas de Campo Grande/MS sobre as populações indígenas do Mato Grosso do Sul. Universidade Católica Dom Bosco, 2008. (Dissertação de Mestrado em Educação). 


\title{
11. ESTUDANTES INDÍGENAS EM ESCOLAS URBANAS: O QUE NARRAM PESQUISADORESE PESQUISADORAS?
}

\author{
Armelinda Borges da Silva (PPGE/UFMT)
}

\section{Introdução}

O Projeto de Pesquisa Educação Intercultural e Colonialidade: Políticas públicas em sociedades indígenas de Mato Grosso, vinculado ao Programa de Pós-Graduação em Educação da Universidade Federal de Mato Grosso (PPGE/UFMT), desenvolve estudos com foco na educação intercultural indígena presente nas regiões Centro-Oeste e Norte. Trata-se de pesquisas relacionadas ao campo educacional no que diz respeito à educação escolar indígena superior, na escola básica e na escola urbana, em áreas da saúde, ambiental, sustentabilidades, economia, cultura, dentre outras. Esse projeto faz parte do Grupo de Estudos e Pesquisas em Educação Escolar Indígena (GEPEEI).

$\mathrm{O}$ interesse principal do projeto de pesquisa, consiste em tecer um recorte da colonialidade, ou seja, discorrer acerca dos padrões mundiais de saber e de poder eurocêntricos difundidos na sociedade como supremos. Apesar da forte presença indígena na sociedade brasileira, perdura a ideia de uma suposta superioridade da cultura do colonizador a ser seguida e trabalhada no currículo escolar, o que desfavorece a aprendizagem dos povos indígenas e não indígenas.

A educação escolar tornou-se um elemento estratégico para os povos indígenas lutarem por direitos perante a sociedade não indígena, o que lhes pode proporcionar mais autonomia, ou provocar dependência do sistema proposto. Nessa perspectiva, o aumento de estudantes em escolas urbanas vem ganhando forças. 
A presença de estudantes indígenas em escolas urbanas vem se constituindo há pouco tempo, mas se intensifica com o passar dos anos. Esse fato se deve aos conflitos enfrentados pelos povos indígenas após o contato com a sociedade não indígena. Dentre outros fatores, destaca-se a diminuição de territórios e consequentemente a redução dos bens naturais disponíveis para a sobrevivência. Como consequência desses e de outros impasses, ocorreu o deslocamento de famílias indígenas para os centros urbanos.

As produções científicas sobre essa demanda também são recentes e ainda em baixa escala. Porém, nas últimas décadas houve o desencadeamento de uma série de dissertações e teses sobre o deslocamento de famílias indígenas para centros urbanos, bem como estudos que investigam a presença de estudantes indígenas em contextos urbanos, apontando para um interesse crescente para tais temas.

O foco deste trabalho consiste, portanto, em apresentar algumas pesquisas desenvolvidas por meio de dissertações, teses e trabalhos relacionados ao indígena em contextos escolares urbanos, centrados nos estados da região Norte e Centro-Oeste. Ao realizar uma pesquisa mais ampla, há o acesso a um contingente maior de trabalhos, tanto nas regiões citadas como no restante do país, porém, no âmbito desse trabalho optou-se pelo recorte das regiões Norte e Centro-Oeste.

\section{Determinantes da migração indígena para os centros urbanos}

Após o contato com a sociedade não indígena, desde a chegada dos colonizadores no local que hoje se denomina Brasil, até os dias atuais, os povos indígenas sofreram uma adversidade de situações desfavoráveis. Isso se deve ao violento embate com o colonizador. Junto com sua sede de obter lucros e usufruir os bens que o "novo mundo" dispunha, trouxeram uma série de doenças ignoradas pelos indígenas, e a contaminação causou uma matança assombrosa.

Os povos indígenas utilizavam seus saberes tradicionais conquistados por seus ancestrais para tratar doenças por meio de remédios feitos com plantas. Porém, com as demandas surgidas, não foi possível criar imediatamente mecanismos para defesa. 
Isso, associado às matanças causadas para a tomada de territórios, bem como à exploração da força do trabalho sem remuneração, foram contribuintes para não apenas diminuir o número dos povos indígenas, mas para alcançar o patamar de extinção de línguas faladas e de povos inteiros. Dessa maneira, os povos indígenas sofreram perdas incalculáveis.

Anteriormente ao contato, os diversos povos indígenas tinham espaços extensos de perambulação, os quais utilizavam para plantar roças, coleta, caça e pesca. Possuíam diversas relações com outros povos vizinhos, como amizade, trocas materiais, guerras, dentre outras. Porém, o contato com a sociedade não indígena ocasionou a redução desses espaços.

Atualmente, muitos povos indígenas vivem aglomerados em terras demarcadas. A título de ilustração, menciona-se a Terra Indígena Rio Guaporé, localizada no município de Guajará-Mirim (Rondônia), e habitada pelos povos Makurap, Aruá, Djeoromitxi, Kanoé, Aikanã, Arikapu, Kujubim, Sakirabiat, Ajuru (Wajuru), Wari, entre outros. A Terra Indígena Rio Branco está situada nos municípios de Alta Floresta do Oeste, São Miguel do Guaporé e São Francisco do Guaporé (Rondônia), habitada pelos povos Tupari, Makurap, Aruá, Djeromitxi, Kampé, Ajuru (Wajuru), Arikapu, Sakirabiat e Djahoi, que, em tempos imemoriais, dispunham de vastas áreas de domínio.

No contexto atual, diversos indígenas, ao longo do território brasileiro, migram para os centros urbanos em busca de melhorias de vida através do acesso ao trabalho assalariado e da educação escolar para os filhos. Enfrentam situações adversas, como a reduzida oferta de trabalho e o preconceito por parte de grande parte da sociedade não indígena.

Com a vinda para a cidade, crianças indígenas passam a estudar nas escolas urbanas não indígenas. Anteriormente, estudavam nas escolas localizadas nas aldeias, inseridas em um contexto indígena; mas passam para um cenário completamente distinto: saem da vida na comunidade indígena e se deparam com um universo diferente daquele a que estavam acostumadas. Também há circunstâncias em que as crianças indígenas já nascem no contexto urbano, devido ao período de fixação dos familiares.

Porém, o ingresso de crianças indígenas em escolas urbanas vindas de escolas das aldeias não ocorre de forma natural. Apesar de ambas as 
escolas terem um currículo em comum, as escolas indígenas têm um currículo diferenciado, voltado para a cultura própria, e na escola não indígena essas particularidades não são abordadas.

Os povos indígenas se deparam com situações de preconceito. Isso se deve à exposição da cultura eurocêntrica como majoritária; as demais são consideradas como inferiores e de pouca relevância social. Esse processo tem vertentes históricas que se perpetuam na cultura dos não indígenas.

A escola pode contribuir para a invisibilidade dos povos indígenas ao não contemplar em seu currículo o estudo da história e cultura indígenas. Assim, com a inserção de crianças indígenas em escolas urbanas, pode haver uma invisibilidade de suas origens, o que contribui para a permanência dos estereótipos.

Estas imagens ofuscadas e distorcidas corroboram para a ocorrência de ações discriminatórias, tal como a insistência em negar a presença indígena na cidade como legítima. Embora os esforços empreendidos para desconstruí-las, essas imagens ainda persistem no dia a dia da cidade (ROSADO; FAGUNDES, 2013, p. 08).

O cenário da escola é composto por indivíduos diferentes, com pensamentos distintos, provindos de variadas culturas. Candau (2008, p. 15) concebe o espaço da escola como local de "[...] cruzamento de culturas, fluído e complexo, atravessado por tensões e conflitos". Remete ao pensamento de Laraia (1986), ao dizer que a herança cultural condiciona o indivíduo a reagir de maneira depreciativa em relação ao comportamento fora dos padrões considerados como normais; e o que foge deste é discriminado.

Conforme o autor, "O fato de que o homem vê o mundo através de sua cultura tem como consequência a propensão em considerar o seu modo de vida como o mais correto e o mais natural" (CANDAU, 2008, p. 72). Dessa forma, as outras culturas podem ser vistas de maneira negativa por estar fora dos padrões culturais considerados majoritários.

A escola precisa mediar os diferentes saberes sem excluí-los ou diminuí-los, mas utilizando-os para reforçar os saberes dos e das estudantes presentes na escola. Bem como problematizar as diferenças presentes na 
sociedade que geram preconceitos, estereótipos e violência. Para Fleuri (2006, p. 11)

De modo geral, portanto, coloca-se a necessidade de se enfrentar os conflitos, de modo a fortalecer as identidades pessoais e culturais, ao mesmo tempo em que construir processos de entendimento e cooperação entre os diferentes grupos sociais. Neste sentido, a relação entre movimentos sociais de diversos matizes, enraizados em contextos diferentes, requer a elaboração de novas linguagens e de novos modelos interculturais à altura da complexidade dos desafios contemporâneos .

Segundo o autor, as relações interétnicas são constantes na história do Brasil, apesar de ser dolorosa e trágica principalmente para os povos afrodescendentes e indígenas. Esses povos contribuíram para a construção da sociedade nacional e muitas vezes não são considerados, passam despercebidos, ou esquecidos de maneira proposital pela sociedade brasileira e no currículo escolar.

\section{Breve compêndio de trabalhos acadêmicos: a presença de estudantes indígenas em escolas urbanas}

Nesta seção, apresenta-se um breve levantamento de dissertações e teses em Programas de Pós-Graduação que tiveram como foco pesquisas desenvolvidas na região Norte e Centro-Oeste do Brasil, acerca da presença de estudantes indígenas em escolas urbanas.

Também abordam-se algumas práticas desencadeadas no Grupo de Pesquisa em Educação na Amazônia (GPEA) da Universidade Federal de Rondônia (UNIR), que priorizou investigar as relações tecidas em escolas urbanas do Estado de Rondônia, no que tange aos e às estudantes indígenas e à comunidade escolar não indígena.

$\mathrm{Na}$ dissertação "Fronteira cultural: a relação entre indígenas e não indígenas em escolas urbanas", do Programa de Pós-Graduação em Educação da Universidade Federal de Mato Grosso (UFMT), Rezende (2002) analisou a percepção de estudantes indígenas e não indígenas sobre a presença do povo Xavante em três escolas urbanas do município de Campinápolis/MT. 
$\mathrm{O}$ autor constatou que as relações escolares entre indígenas e não indígenas são tecidas em meio a conflitos. Tendo como razão a perpetuação de preconceitos construídos historicamente por parte da sociedade não indígena, são inferiorizados em relação aos não indígenas, o que se reflete na escola e na aprendizagem das crianças indígenas.

Destaca ainda a dificuldade da escola como um todo em lidar com a presença indígena, bem como trabalhar a temática. $\mathrm{O}$ fato de muitos povos indígenas não dominar a língua portuguesa contribui para que os e as estudantes fiquem em desvantagem em relação aos estudantes não indígenas, no que diz respeito a aprendizagem e a comunicação. Desse modo,

Quando os "diferentes" chegam à escola, ficam deslocados, não conseguem compreender a linguagem que se usa para lhes ensinar. $\mathrm{O}$ objeto de estudo também não lhes diz respeito, está distante de seu mundo. Se não compreendem a linguagem, e se o objeto de estudos não faz parte de suas experiências de vida, a escola se torna um lugar estranho, onde não é possível sentir-se bem, nem à vontade. É como se a escola fosse um circo, aonde as pessoas chegam, ocupam uma poltrona, assistem a um espetáculo, e, ao saírem de lá, vão viver suas vidas que nada têm em comum com o espetáculo apresentado e que, portanto, quase nada se aproveita para os desafios do dia a dia (REZENDE, 2009, p. 87).

Considera ser de fundamental importância que haja um tratamento igualitário, mas diferenciado, que contribua para superar as barreiras enfrentadas por estudantes indígenas em escola urbanas (REZENDE, 2009).

Pelo Programa de Pós-Graduação em Educação da Universidade Federal de Mato Grosso (UFMT), Both (2006) expõe sua dissertação com o tema "Da aldeia à cidade: o cotidiano de estudantes Paresi em escolas Urbanas de Tangará da Serra-MT". Como informa o título, o autor discute sobre o cotidiano de crianças indígenas do povo Paresi em escolas urbanas no município de Tangará da Serra, Mato Grosso.

$\mathrm{O}$ autor elencou dificuldades e tensões enfrentadas pelas escolas em meio à diversidade étnica indígena nas escolas urbanas. Os indígenas procuram as cidades para cursar os anos finais, não disponibilizados nas escolas 
das aldeias, aumentando a procura do ensino em escolas urbanas. Eles têm o objetivo de estudar em prol de sua capacitação, mas têm o compromisso com o seu povo, por isso se empenham em aprender elementos da cultura do "branco".

O estudo revelou que a prática monocultural das escolas não indígenas contribui para que os e as estudantes Paresi não se reconheçam por meio do ensino, o que prejudica o resultado escolar. Outro fator a ser mencionado é a dificuldade de falar e escrever na língua portuguesa. A barreira linguística causa constrangimentos em sala de aula e dificulta a aprendizagem.

Both (2006) destaca a importância de as escolas dos centros urbanos implementarem uma política multiculturalista na educação escolar, com vistas a conferir maior visibilidade aos diferentes grupos sociais e culturais, com o intuito de lhes garantir o exercício da cidadania, para atender as necessidades dos povos indígenas e consolidar o diálogo intercultural.

Também nesse ano, Freire (2006) desenvolveu o trabalho com o tema "A criança indígena na escola urbana: desafio intercultural", no Programa de Pós-Graduação em Educação da Universidade Federal do Amazonas (UFAM).

A autora constata a presença de crianças indígenas, com destaque no povo Sateré-Mawé em escolas públicas na cidade de Manaus, Amazonas, e analisa o tratamento dado a elas e os desafios encontrados pelas crianças. Buscou entender como se dá a relação cultural em meio à prática pedagógica nas escolas públicas de Manaus. Os resultados da pesquisa mostram que o contexto da escola está envolto por tensões e conflitos.

Assim os índios buscam, através da sua inserção na escola, a incorporação de discursos que lhes tragam a compreensão do que lhes é estranho, ao mesmo tempo em que lhes possibilitem transitar na cultura ocidental: entender a escola, através da apropriação da lógica ocidental, para poderem situar-se na realidade da sociedade envolvente (FREIRE, 2006, p. 98).

A autora sentiu a falta de aprofundamento sobre a temática, por parte de professores e professoras, e a ausência das políticas de formação 
continuada para contribuir na ressignificação da prática atual. Pouco se contempla das diferentes culturas presentes no contexto amazônico, apagam-se as manifestações culturais e prioriza-se a cultura ocidental como referência.

Paladino (2006) escreve a tese de doutoramento intitulada "Estudar e Experimentar na cidade: trajetórias sociais, escolarização e experiência urbana entre 'Jovens' indígenas ticuna, Amazonas”, junto ao Programa de Pós-graduação em Antropologia Social, Universidade Federal de Rio de Janeiro (UFRJ).

Retrata o processo de escolarização de indígenas Ticuna do Alto Solimões, Amazonas, durante o século XX, focalizando uma parcela que vem se constituindo na cidade, sendo um dos motivos o desejo de obter um grau de escolarização mais elevado que os disponíveis nas aldeias. Elenca motivações complexas que contribuem para esse deslocamento.

A autora menciona desafios enfrentados por indígenas Ticuna para se manter nas cidades e estudar. Muitas jovens realizam trabalhos domésticos em troca de favores para permanecer nas casas de "patrões" e ter o acesso à escola. Relatos mostram que veem na escola uma forma de ter acesso a uma educação de qualidade, bem como ter mais contato com a língua portuguesa, conhecer o mundo dos "brancos" e alcançar melhoria social e a condição vivida pelos "brancos".

Ao participar do Programa de Pós-Graduação em Educação, Mestrado e Doutorado da Universidade Católica Dom Bosco (UCDB), Vieira (2008) disserta sobre “'O que interessa saber de índio?’: um estudo a partir das manifestações de alunos de escolas de Campo Grande sobre as populações indígenas do Mato Grosso do Sul.”

Esse autor notou manifestações estereotipadas na prática pedagógica de professores e professoras. A escola ignora a presença indígena e não problematiza tensões e conflitos envolvendo estudantes indígenas. Os manuais didáticos contribuem para transmitir formas de preconceito e discriminação na escola.

Porém, relata que sua pesquisa provocou professores e professoras a refletir sobre sua prática, que pode contribuir para apresentar uma postura mais crítica acerca do que é trabalhado no contexto escolar sobre os povos 
indígenas. $\mathrm{O}$ autor amplia suas investigações ao defender a tese "A criança indígena no espaço escolar de Campo Grande/MS: Identidades e diferenças" (VIEIRA, 2015).

Silva (2013) escreve a dissertação de mestrado com o título "Presença de crianças indígenas em escolas municipais não indígenas de Dourados-MS: A educação na perspectiva intercultural”, no Programa de Pós-Graduação em Educação da Faculdade de Educação da Universidade Federal da Grande Dourados (UFGD).

Durante o estudo, investigou as relações tecidas entre estudantes não indígenas, professores e professoras e estudantes indígenas no recinto educacional. Identificou as barreiras educacionais em escolas públicas urbanas em Dourados, Mato Grosso do Sul e buscou conhecer se a escola desenvolve estratégias para lidar com a interculturalidade. No fim da pesquisa, constatou a ausência de recursos didáticos específicos e de formação pedagógica para lidar com a interculturalidade presente, o que, consequentemente, produz uma homogeneização entre estudantes indígenas e não indígenas, deixando de lado suas particularidades culturais.

Santos (2014), com a pesquisa "Expressões identitárias no espaço escolar: um estudo com estudantes indígenas de escolas públicas urbanas de Ji-Paraná, Rondônia”, apresentou sua dissertação de Mestrado em Educação, desenvolvida no Programa de Pós-Graduação em Educação da Universidade Federal de Mato Grosso (UFMT). Realizou um estudo com estudantes indígenas dos povos Arara-Karo e Gavião-Ikolen, em escolas públicas urbanas do ensino fundamental (anos iniciais) do município de Ji-Paraná, Rondônia. $\mathrm{Na}$ ocasião, acompanhou sete estudantes indígenas, através de observação de aulas ministradas por professoras, observou a rotina dos e das estudantes indígenas na escola, fez entrevistas com profissionais da educação e analisou a relação entre indígenas e não indígenas. Analisou ainda as expressões identitárias dos e das estudantes indígenas, o ser indígena em um contexto distinto do habitual das aldeias em que viviam.

Evidenciou situações em que a criança indígena busca omitir seu pertencimento étnico nos cenários das escolas urbanas, pois nesse local não se identificam como "ser indígena". Mas, apesar de o contexto contribuir 
para omitir sua identidade, as crianças utilizavam, mesmo que discretamente, adereços ou pinturas de seu povo, ou seja, algo vinculado ao seu contexto, que remete a sua identidade étnica.

O ambiente escolar é hostil, pois registra a ocorrência de preconceito, violência verbal, invisibilidade dos e das estudantes. Notou conjunturas de omissão por parte da escola, no que diz respeito a amenizar as situações vivenciadas pelas crianças indígenas, como a ausência de problematizações acerca da presença indígena no contexto amazônico e, especificamente, no contexto escolar urbano em Ji-Paraná.

Ainda nesse ano, Alves (2014) apresenta a dissertação "Infância indígena: narrativas das crianças Arara-Karo na região amazônica”, no Programa de Pós-Graduação em Educação da Faculdade de Educação da Universidade Federal do Rio Grande do Sul (UFRGS). Averiguou a percepção de como cinco crianças narram-se indígenas; elas estudavam em escolas públicas urbanas estaduais no município de Ji-Paraná, Rondônia.

De maneira explícita, foram analisadas as relações tecidas pelas crianças dentro e fora da escola, que mostram a própria percepção de como se veem. A dissertação está recheada pela arte indígena das crianças colaboradoras: há desenhos e fotografias das próprias crianças e da comunidade indígena. Esses detalhes retratam a relação de pertencimento indígena.

As crianças investigadas, apesar de viverem em contexto urbano e estudarem em escolas urbanas, mantêm um vínculo sólido com a comunidade indígena à qual pertencem e se deslocam para esse local com frequência.

Por serem crianças, os nomes não puderam ser citados no trabalho, mas elas, bem como a autora, mostram-se indignados e indignadas, e reivindicaram que suas vozes tivessem vez, pois se fizeram como os e as agentes principais e não foram oportunizados a ter um reconhecimento merecido. Essa percepção demonstra a luta por seus direitos e por serem visibilizados perante a sociedade indígena e não indígena.

Rodrigues (2015) apresenta, ao Programa de Pós-Graduação Stricto Sensu - Mestrado Acadêmico em Educação do Núcleo de Ciências Humanas da Fundação Universidade Federal de Rondônia (UNIR), a dissertação intitulada "A escola urbana e a inclusão de alunos indígenas: os desafios do 
currículo em busca de um diálogo intercultural”. Para tanto, pesquisou uma escola estadual do município de Conquista D'Oeste, Mato Grosso, com estudantes indígenas dos povos Paresi e Nambiquara.

Muitos estudantes se deslocam para o centro urbano para cursar o ensino médio, pois esse nível de estudo é ausente em diversas aldeias, visto que atendem somente o ensino fundamental, principalmente nos anos iniciais. Os e as estudantes indígenas destacam a importância de cursarem o ensino médio para adquirir conhecimentos e para aprender a cultura dos não indígenas, para que sua cultura seja reconhecida e para que sejam respeitados.

A autora menciona uma carência na formação de professores e professoras indígenas com formação superior e em magistério. Também lamenta a ausência de formação específica para professores e professoras não indígenas para trabalhar com estudantes indígenas.

Pondera que o estudo proposto nos centros urbanos é ocidentalizado, sendo um desafio para os e as estudantes indígenas. Nota-se que a interculturalidade entre indígenas e não indígenas é necessária nesse contexto, mas ainda é incipiente e gera desconforto, principalmente para os indígenas.

No período de 2011 a 2013, foi proposto o Projeto de Iniciação Científica "Lápis, caderno, flecha e preconceito: feições da violência institucional com crianças indígenas em Rondônia”, na Fundação Universidade Federal de Rondônia (UNIR), coordenado por Josélia Gomes Neves.

O projeto investigou possíveis situações de violência institucional no cotidiano escolar urbano de Rondônia entre estudantes indígenas e a escola. A pesquisa foi realizada nos municípios de Porto Velho e Ji-Paraná. Após o término, foram encaminhados relatórios aos gestores das escolas acompanhadas, sobre a violência institucional detectada.

A partir desse estudo, outras atividades foram desenvolvidas, como a escrita de artigos científicos e apresentação em eventos e a composição de uma monografia intitulada "Índios urbanos: razões da migração e repercussões das etnias Arara, Gavião e Zoró nas escolas públicas da cidade de Ji-Paraná-RO” (DIAS, 2013) e dois capítulos de livro (PACÍFICO; TAMBORIL, 2013; NEVES; DIAS; SILVA, 2014). Também se desdobrou em pesquisas de mestrado (SANTOS, 2014; ALVES, 2014), já citadas anteriormente nesse trabalho. 


\section{Considerações finais}

Neste texto, realizou-se uma breve exposição de pesquisas desenvolvidas em dissertações, teses e projeto acadêmico sobre estudantes indígenas em escolas públicas em contextos urbanos com povos de estados das regiões Norte e Centro-Oeste. As pesquisas tiveram como cenário determinadas escolas urbanas localizadas em lugares distintos, com povos indígenas variados, porém, os resultados mostram-se semelhantes.

Os pesquisadores e pesquisadoras constataram a dificuldade das escolas em trabalhar com a presença indígena. É frequente a prática de um currículo eurocêntrico como referência, que deixa em segundo plano as culturas consideradas minoritárias, desvalorizando as manifestações culturais dos povos indígenas que passam a fazer parte da escola.

Os motivos que levam os indígenas a se deslocar para as cidades são a procura de trabalho, bem como o acesso a níveis escolares indisponíveis nas aldeias. Os e as estudantes se empenham em aprender a língua portuguesa e os elementos da cultura do "branco", no entanto, a barreira linguística dificulta a aprendizagem.

A carência de recursos didáticos específicos e políticas de formação continuada para trabalhar a interculturalidade contribuem para homogeneizar estudantes indígenas e não indígenas. Há situações em que o ambiente escolar torna-se hostil, com a ocorrência de preconceitos, conflitos, violência verbal, invisibilidade e desconhecimentos dos povos indígenas. Nessa conjuntura, a escola, por não saber lidar com tais ocorrências, ocasiona a omissão e ausência de problematizações acerca das situações vivenciadas e da presença dos povos indígenas no contexto escolar urbano.

Diante das reflexões apresentadas, considera-se este trabalho como uma amostragem do estudo, sendo um convite para o leitor ou leitora aprofundá-lo através de leituras, e até mesmo aguçar o desejo de tornar-se pesquisador ou pesquisadora sobre a inserção indígena em contextos urbanos. 


\section{Referências}

ALVES, Rozane Alonso. Infância indígena: narrativas das crianças Arara-Karo na região amazônica. 2014. 184 f. Dissertação (Mestrado em Educação) Universidade Federal do Rio Grande do Sul, Porto Alegre, 2014.

BOTH, Sergio José. Da aldeia a cidade: o cotidiano de estudantes Paresi em escolas urbanas de Tangará da Serra/MT. 2006. 150 f. Dissertação (Mestrado em Educação) Universidade Federal de Mato Grosso, Cuiabá, 2006.

CANDAU, Vera Maria. Multiculturalismo e educação: desafios para a prática pedagógica. In: MOREIRA, Antônio Flávio; CANDAU, Vera Maria (Orgs.). Multiculturalismo: diferenças culturais e práticas pedagógicas. 2. ed. Petrópolis, RJ: Vozes, 2008.

DIAS, Patrícia. Índios urbanos: razões da migração e repercussões das etnias Arara, Gavião e Zoró nas escolas públicas da cidade de Ji-Paraná-RO. 2013. 189 f. Monografia (Graduação em Pedagogia) Universidade Federal de Rondônia, Ji-Paraná, RO.

FLEURI, Reinaldo Matias. A Produção das diferenças pela escola. In: NEVES, Josélia Gomes [et al.]. Escolarização, cultura e diversidade: percursos interculturais. Porto Velho, RO: EDUFRO, 2013.

FREIRE, Maria do Céu Bessa. A criança indígena na escola urbana: um desafio intercultural. 2006. 118 f. Dissertação (Mestrado em Educação) Universidade Federal do Amazonas, Manaus, 2006.

LARAIA, Roque de Barros. Cultura: um conceito antropológico. Rio de Janeiro: Zahar, 1986.

NEVES, Josélia Gomes; DIAS, Patrícia; SILVA, Armelinda Borges da. Estudantes Indígenas em Escolas Urbanas: quando as diferenças culturais se transformam em violências institucionais. In: BUENO, José Lucas Pedreira; PACÍFICO, Juracy Machado; AMARAL, Nair Ferreira Gurgel do (Orgs.). Qualidade na educação e práticas pedagógicas: realidade e desafios. Florianópolis: Ed. Pandion, 2014.

PALADINO, Mariana. Estudar e experimentar na cidade: trajetórias sociais, escolarização e experiência urbana entre "Jovens" indígenas ticuna, Amazonas. 2006. 366 f. Tese (Doutorado em Antropologia) Universidade Federal do Rio de Janeiro, Rio de Janeiro, 2006.

PACÍFICO, Juracy Machado; TAMBORIL, Maria Ivonete Barbosa. Crianças Indígenas, Escolas Urbanas e Violência Institucional: há lugar para trocas interculturais? In: NEVES, Josélia Gomes; PACÍFICO, Juracy Machado; BUENO, José Lucas Pedreira (Orgs.). Universidade e interculturalidade: anúncio de aprendizagens na floresta. Florianópolis: Ed. Pandion, 2013.

REZENDE, Gerson Carlos. Fronteira cultural: a relação entre indígenas e não indígenas em escolas urbanas. 2002.121 f. Dissertação (Mestrado em Educação) Universidade Federal de Mato Grosso, Cuiabá, 2002. 
RODRIGUES, W. I. S. V. A escola urbana e a inclusão de alunos indígenas: os desafios do currículo em busca de um Diálogo Intercultural. 2015. 112 f. Dissertação (Mestrado em Educação) Universidade Federal de Rondônia, Porto Velho, 2015.

ROSADO, Rosa Maris; FAGUNDES, Luiz Fernando Caldas (Orgs.). Presença indígena na cidade: reflexões, ações e políticas. Porto Alegre: Gráfica Hartmann, 2013.

SANTOS, Vanubia Sampaio dos. Expressões identitárias no espaço escolar: um estudo com estudantes indígenas de escolas públicas urbanas de Ji-Paraná, Rondônia. 2014. 155 f. Dissertação (Mestrado em Educação) Universidade Federal do Mato Grosso, Cuiabá, 2014.

SILVA, Marcela Guarizo da. Presença de crianças indígenas em escolas municipais não indígenas de Dourados-MS: a educação na perspectiva intercultural. 2003. 156 f. Dissertação (Mestrado em Educação) Universidade Federal da Grande Dourados, Dourados, 2003.

VIEIRA, Carlos Magno Naglis. “O que interessa saber de índio?”: um estudo a partir das manifestações de alunos de escolas de Campo Grande sobre as populações indígenas do Mato Grosso do Sul. 2008.126 f. Dissertação (Mestrado em Educação) Universidade Católica Dom Bosco, Campo Grande, 2008.

VIEIRA, Carlos Magno Naglis. A Criança Indígena no Espaço Escolar de Campo Grande/MS: Identidades e diferenças. 2015. 128 f. Tese (Doutorado em Educação) Universidade Católica Dom Bosco, Campo Grande, 2015. 


\title{
12. INDÍGENAS MUDAM O MODO DE FAZER GUERRA: TROCARAM A BORDUNA PELA CANETA!
}

\author{
Anderson Martins (PPGE/UFMT)
}

\section{Apresentação}

Este trabalho visa identificar a forma como os Rikbaktsa concebem a presença da escola em seu cotidiano. No entanto, convém destacar que a validade dos estudos aqui apresentados não se restringe a um único grupo social, mas vai além das fronteiras étnicas, estendendo-se para todas as demais comunidades indígenas do nosso país. Afinal, sabe-se que esses povos foram submetidos a processos bastante semelhantes entre si, no que tange às suas experiências de contato com a sociedade envolvente.

Por várias vezes, eles se viram forçados a usarem a "borduna" para enfrentar os seus inimigos, a fim de garantir a defesa dos seus territórios. A descoberta da "caneta", por sua vez, proporcionou aos autóctones um novo instrumento de luta contra os seus opressores, razão pela qual a maioria dos grupos indígenas brasileiros acabou aderindo à proposta de escolarização. Todavia, ainda não dispomos de dados suficientes para evidenciar essa possível relação entre a educação escolar e o fortalecimento das lutas empreendidas pelos referidos povos em prol do cumprimento dos direitos que lhes são constitucionalmente assegurados. Daí o nosso interesse em realizar esta pesquisa, a partir da trajetória dos índios Rikbaktsa. Inicialmente, pretende-se oferecer uma visão panorâmica sobre alguns elementos históricos e culturais desse povo, a fim de possibilitar uma melhor compreensão em torno dos aspectos relacionados mais diretamente com as suas experiências no campo da educação escolar. Veremos, por exemplo, que os seus primeiros contatos com essa forma de ensino se deram somente a partir do final da década de cinquenta, durante a sua passagem pelo internato de Utiariti. Até então, os Rikbaktsa eram bem pouco conhecidos pelos não 
indígenas, sendo o seu passado considerado uma "incógnita” pelos pesquisadores (PACINI, 1999, p. 09).

Num segundo momento, examinaremos como foi a sua relação com os missionários jesuítas, visto que foram estes os responsáveis pelo processo de "pacificação" ao qual o referido grupo foi submetido. Por fim, acompanharemos alguns depoimentos concedidos por membros da comunidade Rikbaktsa, através dos quais é possível compreender como se deu o seu processo colonizatório sob a perspectiva dos próprios indígenas.

\section{Os Rikbaktsa}

Os Rikbaktsa são reconhecidos como índios brasileiros filiados ao tronco linguístico Macro-Jê. De acordo com Rinaldo Arruda (1992), a palavra Rikbaktsa é composta pelo prefixo Rik, que significa "pessoa" ou "ser humano"; pelo termo $b a k$, que seria um reforço de sentido para expressar a ideia de "verdadeiro"; e pelo sufixo tsa, que constitui uma partícula utilizada na respectiva língua para colocar o substantivo no plural. Assim, o nome Rikbaktsa corresponderia à ideia de que "somos gente de verdade", designando, assim, o modo como o referido povo compreende a si próprio ${ }^{1}$.

Acredita-se que eles chegavam a aproximadamente 1.300 habitantes, antes de estabelecerem os seus primeiros contatos com os não indígenas. Viviam se deslocando de um lugar para o outro à procura de alimentos, acompanhando os diferentes ciclos da natureza. De acordo com os depoimentos prestados por alguns dos seus integrantes, eles são antigos habitantes da bacia do Juruena, onde permanecem até hoje. É óbvio que já não gozam mais da mesma liberdade que costumavam desfrutar em outras épocas, pois, com a chegada dos colonizadores àquela região, simplesmente foram proibidos de terem livre acesso às extensas áreas que antes compu-

\footnotetext{
${ }^{1} \mathrm{Na}$ região onde estão localizados, os Rikbaktsa são também conhecidos como Canoeiros, devido à notável habilidade demonstrada por eles na utilização de suas canoas. Outros ainda costumavam chamá-los de Orelhas de pau, visto que antigamente a maioria dos homens andava com enormes batoques de madeira pendurados em seus lóbulos auriculares (Arruda, 1992). Mas foi o Padre Adalberto de Holanda Pereira que começou a utilizar a auto-denominiação em 1961, quando pesquisava os mitos Rikbaktsá (Rodrigues, 1986, p. 133).
} 
nham o seu habitat tradicional. Vejamos o que nos diz Arlindo Pudata a respeito daquele passado que, segundo nos parece, ainda se faz bastante presente na memória desse povo:

Antigamente, a gente vivia aqui mesmo nessa região, só que era bem diferente de hoje, porque a nossa terra não tinha limite, a gente andava por todos os cantos, indo desde lá da barra do Papagaio até chegar lá embaixo no Salto Augusto. Eu conheço isso aí tudo, mas com a chegada dos 'brancos' tudo foi se modificando, daí a gente foi perdendo a nossa terra, ficando só com essa área que a gente mora hoje. Mas quase que a gente fica sem nada, porque foi muito difícil pra conseguir essa demarcação, foi preciso muita luta e teve gente que quase morreu por causa disso. (Pudata. Depoimento coletado em 15 de março de 2016).

Temos um breve relato obtido junto a uma liderança que nos dá uma noção sobre como eram alguns aspectos ligados ao cotidiano do povo Rikbaktsa. Percebe-se, por exemplo, que eles levavam uma vida aparentemente marcada pela ausência de certos limites territoriais, até virem a ser confrontados com a presença dos não indígenas. A propósito, convém destacar que os espaços tradicionalmente ocupados pelo referido grupo correspondiam a uma área estimada entre cinco a doze milhões de hectares, de acordo com os levantamentos feitos por alguns pesquisadores. Isso é confirmado pelo Pe. João Evangelista Dornstauder², ao tecer as seguintes observações:

Os Rikbaktsa ocupavam uma extensa área, orçada em $50.000 \mathrm{~km}^{2}$, se contado o território residencial e mais o de correrias, pois além de percorrerem largamente o município de Aripuanã, onde tinham algumas

\footnotetext{
${ }^{2}$ Trata-se de um padre jesuíta de nacionalidade austríaca que assumiu a responsabilidade pela condução do processo de pacificação dos Rikbaktsa no final da década de 1950. Uma das obras que descreve o tipo de relação estabelecido entre ele e o referido povo tem por título Como pacifiquei os Rikbaktsa (1975), compilada a partir dos registros feitos pelo missionário durante os seus primeiros contatos com aquele grupo. Recentemente, o professor e antropólogo Aloir Pacini publicou um livro intitulado Um artifice da paz entre os índios e seringueiros, onde descreve a trajetória percorrida por João Dornstauder, no tocante às suas ações missionárias pelo interior matogrossense.
} 
aldeias, também habitavam o baixo curso do Arinos, do Sangue, do Papagaio, com menos chão de correrias. Pode-se dizer que o território de movimentação habitual se restringisse a $12.000 \mathrm{~km}^{2}$. Do Papagaio até a altura da barra do Arinos, ocupavam quase exclusivamente a margem direita do Juruena, mas, da altura da barra do Arinos para baixo, moravam na margem esquerda e vagueavam largamente pelas duas margens. Seu território ficava compreendido pelos paralelos $9^{\circ}$ e $12^{\circ}$ Lat. Sul e os meridianos $56^{\circ}$ e $59^{\circ}$ Long. W. Gr. (DORNSTAUDER, 1975, p. 2).

Atualmente, a população Rikbaktsa conta com cerca de mil e quatrocentos habitantes, segundo dados do IBGE (Censo 2010), cujas famílias estão distribuídas em três territórios demarcados e homologados pelo Governo Federal, a saber: a Terra Indígena Erikpatsa, a Terra Indígena Japuíra e a Terra Indígena do Escondido, encontrando-se estas situadas respectivamente nos municípios de Brasnorte, Juara e Cotriguaçu, região Noroeste de Mato Grosso $^{3}$. Somadas, essas três Terras Indígenas formam aproximadamente quatrocentos mil hectares, o que significa uma drástica redução territorial perto dos $50.000 \mathrm{~km}^{2}$ anteriormente ocupados pelo referido povo.

\section{A guerra contra os seringueiros}

A partir desses dados, já é possível prever qual seria o desfecho daquele gradativo e exacerbado processo de desterritorialização que se abateu sobre a trajetória dos Rikbaktsa. Ao se depararem com o acelerado avanço das frentes expansionistas sobre os seus territórios, os autóctones se viram forçados a lutar em defesa dos espaços tradicionalmente ocupados por eles. Iniciava-se, assim, uma dramática e sangrenta batalha entre os

\footnotetext{
${ }^{3}$ A primeira T. I. a ser demarcada para os Rikbaktsa foi a Reserva Erikpatsa, cuja criação se deu em 1968 sob o Decreto Federal no 63.368, sendo essa área composta por 79.934 ha; quase vinte anos depois (1985), ocorreu a demarcação do Território Indígena Japuíra, abrangendo um total de 148.450 ha; por fim, houve também a conquista da demarcação do Território Indígena do Escondido (1998), com um espaço equivalente a 169.139 ha.
} 
indígenas e os grupos invasores ${ }^{4}$. De um lado, estavam os índios com os seus arcos e flechas; do outro, encontravam-se os seringueiros entrincheirados com suas armas de fogo. $\mathrm{O}$ resultado desse duelo não poderia ter sido muito diferente: sucessivas baixas entre os combatentes, tanto de um lado quanto do outro. Vale destacar que os Rikbaktsa se revelaram como grandes guerreiros, organizando-se estrategicamente em várias equipes para promoverem os ataques aos seus inimigos, conforme as observações feitas pelo missionário jesuíta Pe. José de Moura e Silva:

Os índios Rikbaktsa aparecem, pois, pela primeira vez na História, na ocasião da abertura dos seringais da terceira borracha. Não viram com bons olhos as armas dos seringueiros, quando verificavam se essa gente nova eram Rikbaktsa vindos do céu. Os seringueiros afoitos declararam a guerra. Os Rikbaktsa mostraram-se excelentes guerreiros, impressionando os seringueiros com ataques armados num mesmo dia e numa mesma hora, em pontos distantes, numa ação conjunta de fôlego. Com a fama de matarem e devorarem os seus inimigos, conseguiram impor-se por bom tempo na guerra. Surgiam como espectros e se davam por desaparecidos, quando os seringueiros os procuravam nas aldeias. Utilizavam flechas incendiárias e borduna. Eram tidos como valentes e audazes. (SILVA, 1975, p. 6).

Segundo o autor, esses conflitos tiveram início em meados da década de 1940, durante o terceiro ciclo da borracha, estendendo-se por cerca de dez anos (SILVA, 1975, p. 4). Quanto às frentes expansionistas, estas eram constituídas em sua maioria por seringueiros que haviam se instalado na região para se dedicar à extração do látex ${ }^{5}$. A invasão aos territórios indígenas

\footnotetext{
${ }^{4} \mathrm{O}$ antropólogo Aloir Pacini (professor da UFMT/Cuiabá) realizou diversas pesquisas ligadas à temática sobre os territórios indígenas, sendo que uma delas está diretamente relacionada com a trajetória dos Rikbaktsa, a saber: Pacificar, Relaçôes Interétnicas e Territorialização dos Rikbaktsa (1999). Trata-se da sua dissertação de Mestrado, cujos estudos certamente contribuem para um maior aprofundamento acerca do referido tema, em parte publicada (2015).

${ }^{5}$ Uma das obras que nos oferece uma visão panorâmica acerca dos conflitos gerados a partir do processo de implantação desse projeto exploratório é A batalha da borracha na Segunda Guerra Mundial e suas conseqüências para o vale amazônico, publicada em 1988 pela Universidade Federal do Acre, de autoria de Pedro Martinello.
} 
contou, por sua vez, com o aval do próprio Governo do Estado de Mato Grosso, visto que era este quem "arrendava as matas para a exploração da borracha nativa”. A esse respeito, o padre jesuíta explica que

Tudo começou com o arrendamento indiscriminado de seringais e igualmente com a indiscriminada venda de terras. Frente à confusão reinante, após liberações fáceis, poucas pessoas se resignaram a ver a situação como passível de solução. Desses pressupostos, para a invasão das terras dos índios e daí para a guerra, não se dava mais que um passo. (SILVA, 1975, p. 8).

Juntamente com o apoio político prestado pelos representantes do Poder Executivo Estadual - e aqui vale destacar que, na verdade, se tratava de um projeto econômico e sociopolítico bem mais amplo, cujo movimento ficou nacionalmente conhecido como a Marcha para o Oeste -, havia também outras formas de incentivos que eram oferecidas aos seringalistas, a fim de que estes pudessem garantir o máximo de sucesso em seus empreendimentos. Recorremos, mais uma vez, aos apontamentos feitos pelo Pe.José de Moura e Silva, o qual nos oferece as seguintes informações:

Denominaram-se seringalistas os arrendatários. Esses, por sua vez, conseguiram do Banco de Crédito da Amazônia empréstimos favoráveis, para cobrirem as despesas de penetração, com carros e barcos; despesas de construção de ranchos e depósitos, casas dos seringueiros, chamadas feitorias; assim como alimentação, material de uso pessoal e técnico de extração de borracha. (SILVA, 1985, p. 5).

Porém, essa política de arrendamento de terras ocorrida em Mato Grosso acabou se constituindo num sério problema para aqueles que se encontravam envolvidos mais diretamente com as atividades relacionadas à exploração da borracha, isto é, os seringueiros. Isso sem falar dos enormes transtornos que tal projeto haveria de representar na vida dos diversos povos que habitavam a vasta região do Noroeste Matogrossense ${ }^{6}$. Agora, o

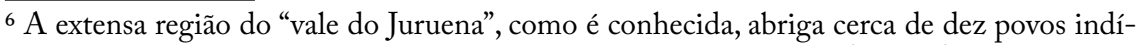
genas pertencentes a diferentes etnias, a saber: Rikbaktsa, Manoki (Irantxe), Mÿky, Pareci, Apiaká, Kawaiweté (Kayabi), Munduruku, Cinta-Larga, Enawenê-Nawê e Arara.
} 
grande desafio que se apresentava às autoridades governamentais consistia em encontrar alguma solução para a situação de conflito que havia se desenvolvido entre os autóctones e os seringueiros. É dentro desse contexto, pois, que teve início a articulação protagonizada pelos jesuítas.

\section{A ação pacificadora dos jesuítas}

Com o intuito de promover um acordo de paz junto aos diferentes atores sociais envolvidos naquele acirrado estado de guerra em curso na bacia do Juruena, alguns membros da Companhia de Jesus se propuseram a elaborar uma estratégia de pacificação ${ }^{7}$. À frente dessa missão, encontrava-se o Pe. João Dornstauder, o qual acabou exercendo um papel determinante no processo de resolução dos conflitos que vinham se arrastando entre os índios e os seringueiros. A seguir, insere-se um fragmento extraído dos diários do missionário, onde encontram-se alguns registros dos primeiros passos que foram dados por ele, no sentido de tentar convencer as autoridades eclesiásticas e políticas da época a prestarem o seu apoio ao referido projeto. Assim descreve o religioso:

O bispo-prelado de Diamantino, informado pelo Pe. Dornstauder da situação da guerra, mandou que o mesmo Pe. Dornstauder se dedicasse à pacificação dos Rikbaktsa e ajudasse os seringueiros. $\mathrm{O}$ Pe. Dornstauder procurou convencer da necessidade da pacificação o S.P.I. (Serviço de Proteção aos Índios). Por infelicidade, mesmo outras pessoas interessadas intercedendo e até mesmo os seringalistas, o S.P.I. não atendeu. A Prelazia de Diamantino assumiu a responsabilidade da pacificação. (DORNSTAUDER, 1975, p. 8).

\footnotetext{
${ }^{7} \mathrm{O}$ termo "pacificação" será empregado, ao longo deste trabalho, a partir da acepção adotada pelos jesuítas dentro do contexto das relações interétnicas estabelecidas por eles junto às populações indígenas com as quais mantiveram contato, a partir da década de 1940, no interior do Estado de Mato Grosso. Veremos que, segundo o Pe. Dornstauder, a tarefa de "pacificar" os autóctones constituía uma dimensão intrínseca à própria ação missionária desenvolvida por ele junto aos respectivos grupos, enquanto resposta ao acirramento dos conflitos desencadeados entre os índios e os não indígenas. Por isso, a utilização de aspas para dar destaque àquela expressão ocorrerá somente quando houver a intenção de lhe atribuirmos um sentido diferente daquele definido para os propósitos desta pesquisa.
} 
Mais adiante, o Pe. João Dornstauder relata que ele de fato contou com o apoio moral e financeiro por parte dos seringalistas, como é o caso do Sr. Benedito Bruno, pois aquela proposta da pacificação interessava a esse segmento, já que facilitaria a continuidade dos seus empreendimentos econômicos na região. A julgar pelas aparências, poderíamos dizer que os jesuítas agiram com certa parcialidade, colocando-se mais a favor dos invasores do que em benefício dos indígenas. Tal suspeita torna-se ainda mais latente, ao nos deparamos com outros registros deixados pelo missionário, através dos quais ele parece manifestar uma especial preocupação com os problemas enfrentados pelos seringueiros, expressando-se da seguinte maneira:

A maioria dos seringueiros veio trabalhar no seringal para melhorar de vida e superar mais rapidamente o seu estado de miséria. Esta esperança desvanecia-se ao surgir-lhes inesperadamente pela frente o índio. Assim, foram constrangidos a defender a vida e o pão para si e para suas famílias. Empresários e patrões, colocados em semelhante situação da presença inesperada do índio, entreviam a catástrofe econômica de maiores proporções, pois a borracha constituía importante parcela da economia nacional. $\mathrm{Na}$ extração do látex empataram as posses, prestígio e posição social. (DORNSTAUDER, 1975, p. 30).

Ou então, quando somos conduzidos a este outro trecho de suas anotações:

A situação angustiante, tanto do índio, quanto do seringalista, recaiu exacerbada sobre o humilde seringueiro: falta de mantimento, quando não era servido estragado; malária e outras doenças; insetos perseguindo dia e noite; arbitrariedades da administração do seringal acompanhadas pelos imprevistos; transporte incerto; exigência de entregar a borracha que não era possível tirar; pesadelo em toda hora e todo lugar do índio presente sem se deixar ver. $\mathrm{O}$ resultado do inferno seringueiro era o assomo de revolta contra tudo, era o clima de ódio aos Rikbaktsa, mormente quando o sangue dos companheiros tombados aparecia grudado na feitoria, na borracha, na canoa. (DORNSTAUDER, 1975, p. 30) 
Considerando-se o conteúdo desses excertos, fica evidente que o Pe. João Dornstauder se demonstrava bastante sensibilizado com os problemas enfrentados pelos seringueiros, diante das circunstâncias nas quais se encontravam. Contudo, não podemos concluir que os jesuítas estivessem mais empenhados na defesa dos interesses daquele segmento do que no favorecimento aos autóctones. Até porque há outras passagens retiradas dos seus diários em que o autor revela um profundo apreço pelos Rikbaktsa, chegando mesmo a socorrê-los, após ter se deparado com vários de seus membros em estado já bastante avançado de debilidade física, conforme os relatos que seguem:

Dia 27[07-1958]. Visito os Rikbáktsa da vertente do Juruena. Ao atravessar o córrego da aldeia do Milho, vêm algumas crianças. O primeiro movimento delas é fugir. Param, porém, e nos acenam amigavelmente. Uma menina corre a avisar a aldeia. Nossa saudação de longe não encontra resposta entusiasmada. Rodeio a casa e entro. A maioria jaz doente. Curioso que gente sã resista no meio de doentes, principalmente algumas crianças. Íxo me convida para sentar num lugar livre, sobre talos de paxiúva. Sua, tosse, olhos inchados e lacrimejantes. Parece carregar o peito cheio de escarro. Ao tossir, pouco expectora, apesar do esforço que faz. [...] Das doze pessoas, a mulher de Íxo parece em estado grave, mas sorri com naturalidade. Também Nipói tosse muito, emagrecido, de olhos crescidos, o tórax avultando contra os membros esqueléticos. Quando de cócoras, Nipói parece estar no ponto de ser enterrado. Úmoa tosse e sua mulher emagrecida tosse de mansinho, não querendo incomodar os vizinhos. Sorri com naturalidade. Meguedati fala baixo com medo de tossir repentinamente no meio da palavra. Recupera-se. É o menos esquelético de todos. Úmoa e Meguedati são irmãos de Íxo. O menino Voca e a menina Tumoma, de dez anos, tossem pouco. Tipo esquisito de gripe este: sem febre, com tosse e grande mal-estar. Aplico logo injeção aos quatro mais necessitados e armamos as redes fora da casa, ao lado. A atenção e interesse logo se deslocam para o nosso canto. (DORNSTAUDER, 1975, p. 146). 
Portanto, qualquer tipo de inferência que viesse a implicar na emissão de algum juízo moral acerca do posicionamento adotado pelos missionários católicos em relação aos dois grupos, indígenas e seringueiros, poderia estar sujeito a sérios e inconsequentes equívocos. A fim de evitarmos esse tipo de constrangimento - absolutamente desnecessário, segundo o nosso entendimento -, optamos por concentrar a nossa atenção em torno daqueles aspectos que realmente possam contribuir para uma compreensão mais ampla sobre os impactos decorrentes daquela intervenção pacificadora na vida dos Rikbaktsa. Aliás, o próprio Pe. João Dornstauder já havia se encarregado de esclarecer o sentido atribuído à sua missão, ao fazer as seguintes observações:

Sob o ponto de vista sócio-humanitário, missão igual era a dos Rikbaktsa e a dos seringueiros. Duas faces de uma só moeda, como cara e coroa de um mesmo problema. Pacificar a quem quer que seja, durante uma guerra estalada, sempre vem a ser um mal menor. Não é um programa sujeito a discussões, visando a melhorias. Trata-se de salvar o possível. Utopia prever médios e longos prazos na emergência de um salvamento. Não satisfaz aos seringais e às colonizações, pois a pacificação impõe, entre e a frente conflagrada, grupos humanos neolíticos, descompassados e anacrônicos. Não satisfaz aos Rikbaktsa, porque lhes impõe a restrição do espaço vital e a forçada presença de indivíduos mal-encarados. Mas é a única opção viável. (DORNSTAUDER, 1975, p. 31).

A partir dessas considerações, é possível concluir que as ações empreendidas pelos jesuítas visavam beneficiar a todos, independentemente da posição social ocupada pelos diferentes sujeitos contemplados pelo referido projeto. Em outras palavras, os propagadores da fé cristã concebiam a sua missão como uma tarefa sócio-humanitária, antes de assumi-la como uma atividade meramente religiosa. Isso não significa, porém, que os contatos estabelecidos junto aos Rikbaktsa tenham resultado necessariamente em benefícios para aquela população. A propósito, acreditamos que as únicas pessoas habilitadas a fazerem esse tipo de avaliação são os próprios membros daquela comunidade, já que foram eles os principais afetados pelas operações realizadas pelos missionários católicos e pelos seringueiros. 


\section{As técnicas e estratégias de pacificação}

No tópico anterior, vimos quais foram os principais fatores que concorreram para a deflagração dos conflitos estabelecidos entre os Rikbaktsa e os seringueiros, destacando que aquela situação foi motivada pela intensa disputa territorial que se desenvolveu entre os dois grupos no alto curso do Rio Juruena. A questão que se coloca agora para nós diz respeito à forma como os jesuítas colocaram em prática o seu plano de pacificação social, isto é, falta explicitar os aspectos operacionais relacionados àquela intervenção sócio-humanitária. Quais foram, por exemplo, os métodos e as estratégias empregados pelos missionários para alcançar os fins desejados?

Uma das primeiras atitudes assumidas pelo Pe. João Dornstauder, no tocante às suas operações missionárias, consistiu em tentar convencer os seringueiros a mudarem de tática: "em vez de hostilizar, entrar num jogo de trocas pacíficas com os Rikbaktsa, pois assim ambos sairiam ganhando" (PACINI, 1999, p. 32). Num segundo momento, já o encontramos estabelecendo os seus primeiros contatos com os autóctones, apresentando-se a eles de forma amigável, a fim de convencê-los a acreditar que ele era diferente dos seringueiros. Além disso, o religioso teria passado a dar presentes aos índios, utilizando-se aí de uma técnica bastante comum nesse tipo de situação. É o próprio missionário quem nos oferece maiores detalhes sobre essa etapa do seu projeto, a saber:

Deixaremos presentes, coisas úteis, como machado, facão, continhas para colares. Mas um pano branco, levando no centro uma cruz ou também um emblema vermelho, de um grande $\mathrm{P}$, cortado por um hífen, como se fosse $\mathrm{P}$ e $\mathrm{F}$ ao mesmo tempo, acompanhará vistosamente os presentes. $\mathrm{O}$ índio verá primeiro a bandeira ou a flâmula, depois os presentes. Levaríamos os da turma de pacificação, um pano como senha, idêntica ao símbolo posto junto dos objetos. Levaríamos no peito, no barco, no acampamento, em toda circunstância, no esforço de induzir o reflexo condicionado de bom encontro. (DORNSTAUDER, 1975, p. 45). 
Além dessa estratégia, o Pe. Dornstauder também fazia várias exigências aos integrantes da sua equipe de trabalho, como a proibição do uso de armas contra os índios (1975, p. 45). Com efeito, parece que não haveria muito sentido falar em "pacificação" sem que os seus responsáveis evitassem aquele tipo de conduta. No mínimo, estaríamos diante de uma situação contraditória, caso as orientações repassadas pelos missionários aos seus colaboradores tivessem seguido noutra direção, dizendo-lhes: "Caros companheiros, levem consigo as suas armas de fogo!". Vale lembrar que o Marechal Rondon era militar e também costumava exigir dos seus subalternos um cuidado especial para com os índios, dando-lhes a seguinte ordem: "Morrer, se preciso for; matar, nunca!" No entanto, temos a impressão de que esses diferentes agentes não se davam conta de que a simples presença deles em territórios indígenas poderia representar, em si mesma, um ato de violência contra os autóctones, ainda que não houvesse da sua parte a intenção de causar qualquer tipo de dano ou prejuízo àquelas populações.

Apesar das cobranças feitas pelo Pe. Dornstauder aos seus apoiadores, a fim de se garantir o estabelecimento de uma relação pacífica junto aos indígenas, houve quem the desobedecesse, colocando em risco o bom êxito dos empreendimentos assumidos pelos missionários. Estamos nos referindo aqui ao caso de Domingos, um dos responsáveis pelo assassinato de um índio conhecido pelos seus pares como Tatzã. Esse fato ocorreu depois de já transcorridos cerca de cinco anos do início dos trabalhos ligados ao processo de pacificação dos Rikbaktsa. De acordo com o religioso, aquela situação quase acabou fugindo ao seu controle, conforme explica a seguir:

Dia 15 de agosto de 1962, às 13 h e 30 min., estou à espera do seringueiro Aquino [...]. Domingos relata que, quando chegou à feitoria, surpreendeu os índios saindo da feitoria carregando roupa de Judite, um grande despertador e outras coisas. Recolheu tudo. Os índios "embraveceram" e ameaçaram-no, como se quisessem flechá-lo. Domingos disse que não o fizessem, porque ele era seringueiro bom [...]. Domingos desceu a buscar sernambi para fazer fogo. Naíc pescava na canoa, os dois moços ocupados no jirau, Tatsã deitou na rede, esticada bem por 
cima da borracha. Tatsã teria falado: "Arroz não presta! Seringueiro não presta!" E levantou-se da rede, pegando o arco. Num ímpeto descontrolado, Domingos puxou do revólver e atirou em Tatzã: "Se seringueiro não presta, então toma!” (DORNSTAUDER, 1975, p. 184-186).

Além das estratégias elencadas, os jesuítas se valeram também de outros recursos metodológicos, como a companhia de alguns índios pertencentes a outros grupos étnicos existentes na região, durante as primeiras fases ligadas à execução do seu projeto pacificatório. Acreditava-se que a participação desses interlocutores, como os Kayabi, poderia facilitar o processo de aproximação que os missionários pretendiam estabelecer junto aos Rikbaktsa. Ao refletir sobre os detalhes desse plano, o Pe. João Dornstauder aponta as razões que o levaram a incluir outros autóctones em sua equipe de trabalho, avaliando a presença deles como fundamental para se conquistar mais facilmente a confiança dos demais índios que haveriam de ser pacificados. Assim diz ele:

Far-me-ia acompanhar de índios de outras tribos, mesmo difíceis de manejar e impressionados com os Rikbaktsa. Para o Rikbaktsa, não podia usar de melhor argumento do que andarem outros índios à procura dele. Isto sem contar as facilitações que os índios me trarão nas caminhadas, na discussão de rumos, na intuição do que fazer entre os índios. Poria em movimento o trunfo da inspiração do coração e do instinto particular, que só os índios possuem no mato. (Op. cit., p. 46).

Portanto, temos aí uma visão geral sobre as principais técnicas e estratégias utilizadas pelos jesuítas, no decorrer do processo de pacificação dos Rikbaktsa. Apenas lembrando que o emprego daqueles recursos não constitui um fato inédito dentro do contexto mais amplo das relações intersocietárias estabelecidas entre índios e não indígenas, conforme nos revelam as inúmeras obras de caráter historiográfico existentes ao nosso redor. A seguir, veremos como se deu a realização do projeto descrito acima sob uma nova perspectiva, isto é, a partir do olhar dos próprios sujeitos a quem se procurou pacificar: os índios. Desse modo, pretende-se dar a 
eles a oportunidade de apresentarem a sua versão sobre os acontecimentos relacionados ao seu processo de pacificação. Afinal, qual será a visão dos Rikbaktsa em torno daqueles eventos históricos? Será que realmente estavam dispostos a aceitarem o acordo de paz proposto pelos jesuítas? $\mathrm{Ou}$ será que o fizeram de forma involuntária, movidos apenas pelas forças das circunstâncias?

\section{A pacificação sob o olhar dos Rikbaktsa}

Narrar a história da pacificação dos Rikbaktsa a partir do campo de visão dos próprios autóctones representa um grande desafio para nós, visto que não há entre eles documentos que nos permitam realizar esse tipo de investigação. Isso porque não faz parte das suas práticas culturais o hábito de fixarem por escrito os principais fatos e acontecimentos que permeiam o seu cotidiano. A ausência de tais registros não nos impede, porém, de escutar o que eles têm a nos dizer sobre algumas experiências ligadas ao seu passado, visto que muitas informações ainda estão bastante presentes na memória coletiva daquele povo, mantendo-se vivas através da comunicação oral. E uma grata surpresa é observar como essa oralidade possui vínculos bem estabelecidos para que assim consigam refletir a respeito das aprendizagens históricas realizadas, mesmo que numa linguagem até mitológica.

Sendo assim, esta etapa da nossa pesquisa será pautada basicamente pelos relatos coletados junto àqueles indivíduos que chegaram a participar de forma mais direta, ou então indiretamente, dos primeiros contatos estabelecidos entre eles e os missionários católicos. $\mathrm{Na}$ verdade, a maioria das pessoas que tiveram a oportunidade de acompanhar um pouco mais de perto aquele processo já não se encontra mais presente na comunidade, pois o tempo se encarregou de levá-las para o mundo dos mortos. Pomy é um dos poucos sobreviventes do povo que presenciou o primeiro encontro pacífico com o Pe. Dornstauder a uma das aldeias Rikbaktsa. Numa entrevista concedida à professora Patrícia Itaibele, nossa amiga e colega de profissão, ele relata como foi a sua experiência de encontro com o missionário, descrevendo-a da seguinte forma: "Nós foi pegar peixinho, tinha 
muito aqui. Aí nós voltando, apareceu eles. O padre João, barbudo, parecia um bicho. Nós correu, nunca tinha visto. Quase matei o padre João com a flecha”. (2015, p. 30).

Por meio dessa breve narrativa, é possível notar o enorme espanto manifestado por Pomy, ao se deparar com aquele homem estranho, enquanto desciam para apanhar peixinhos no rio. Vale ressaltar que, na ocasião, o nosso interlocutor deveria contar com cerca de dez anos de idade; portanto, ele era apenas uma criança quando se deu aquele fato. Uma das coisas que chamam a nossa atenção no relato exposto é a forma como o autóctone descreve a aparência física daquele sujeito que vinha andando em sua direção. Pomy achou que ele fosse um "bicho", devido às longas barbas do religioso. Já o missionário, ao fazer o registro daquele episódio em seus diários, revela-nos um olhar bem diferente daquele apresentado pelo indiozinho, saber:

Dia 30 de julho de 1957. Marchamos cedo [...]. Com meia hora de marcha, de repente, percebo um movimento por entre ramos e folhas, manchas de cor dançando. São Rikbaktsa a tirar embira de um pau. Quero ver melhor. Assoma alguém. Penso que é moça, a julgar pela impressão do momento, e trato como se fosse moça. Empunha arco e flecha. Mais tarde iria saber que era homem, o índio Pomy. (DORNSTAUDER, 1975, p. 89)

\section{O Pe.João Dornstauder, um Ancestral Rikbaktsa}

Em seu relato, Pomy também afirma que ele estava acompanhado por mais alguém, ao se deparar com a chegada do padre jesuíta. Segundo ele, tratava-se do Rafael. Há pouco tempo, tivemos a oportunidade de conversar com esse grande líder comunitário e ouvi-lo contar várias histórias relacionadas à vida do seu povo, dentre elas, uma que se refere ao período da pacificação. Apesar do peso da idade, ele se mostrou uma pessoa bastante lúcida e cheia de vitalidade, fazendo algumas observações interessantes acerca do seu inesperado encontro com o Pe. João Dornstauder. Disse-nos, por exemplo, que o missionário só acabou sendo bem recebido pelos 
Rikbaktsa, naquela ocasião, por ter sido identificado pelos anciãos como um dos seus antepassados que havia retornado para ajudá-los a vencer a batalha contra os seus inimigos.

A propósito, trata-se aqui de uma informação que já havia sido assinalada por Odilo Pedro Lunkes (1978, p. 17-20), através de uma pesquisa realizada junto ao referido povo. Também convém ressaltar que o missionário possuía um notável espírito de liderança, o que lhe permitia conquistar mais facilmente o respeito e a confiança das pessoas com as quais mantinha contato $^{8}$. A mesma versão é narrada também pelo Pe. Moura (1975, p. 9), ao destacar que "um chefe (Íxo) chegou a sonhar que aquele pacificador era um Rikbaktsa redivivo”. Com esses testemunhos congruentes, parece que o principal motivo da sua ascendência junto aos Rikbaktsa esteja no fato de o reconheceram como um antepassado que estava voltando para auxiliar nessa guerra contra os seringueiros.

A ênfase dada à forma como o Pe. João Dornstauder foi acolhido pelos Rikbaktsa não é desprovida de significado. Ao conferirem o status de "parente" a alguém que, até então, era-lhes totalmente desconhecido, os membros daquela etnia tornaram possível o bom êxito da missão assumida pelo líder religioso junto deles, no tocante ao acordo de paz que logo mais viria a ser firmado com os seringueiros. Nas palavras de Odilo Lunkes, pode-se dizer que "o método usado na pacificação foi de tal acerto e revelou tal conhecimento da índole indígena, que os próprios nativos consideraram o Pe. João como 'um Canoeiro que voltou à tribo"' (LUNKES, s.d V, apud PACINI, 1999, p. 15).

\section{A intervenção dos Jesuítas era necessária?}

Diante do surpreendente sucesso alcançado pelos jesuítas, no tocante ao processo de pacificação realizado junto ao povo Rikbaktsa,

\footnotetext{
8 De fato, o Pe. João Dornstauder costumava usar de uma estratégia para reforçar sua autoridade, perguntando no início de cada expedição: "Quem manda aqui?” E “todos lhe davam a direção do empreendimento porque ele gostava de estar à frente dos trabalhos”. O grande propagador desta versão foi o grande cacique Mapadadi Rikbaktsa. Por isso o religioso era visto como um "sertanista" pelo SPI, tido como "missionário" pela Igreja Católica e considerado como um "parente" pelos Rikbaktsa (Pacini, 1999, p. 15, 59-64).
} 
poderíamos indagar: será que a presença daqueles missionários entre os índios e seringueiros foi decisiva para que fosse estabelecido o fim das dissensões que, há algum tempo, vinham se arrastando entre os dois grupos? Até que ponto os Rikbaktsa dependiam dos serviços prestados pelos padres católicos para firmarem um acordo de paz com os seus inimigos? Será que não existe uma tendência, por parte de alguns pesquisadores, de supervalorizar as ações empreendidas pelos membros da Companhia de Jesus, exaltando-se, por exemplo, a figura do Pe. João Dornstauder? E onde fica o protagonismo dos autóctones? Será que não estaríamos, por outro lado, simplesmente menosprezando a capacidade desses bravos guerreiros para encontrarem uma solução pacífica aos problemas relacionados à chegada das frentes extrativistas aos territórios que compunham o seu habitat tradicional?

É óbvio que não temos condições de oferecer uma resposta clara e objetiva às questões elencadas, apesar de considerá-las relevantes dentro do quadro reflexivo que está sendo desenvolvido neste capítulo. De fato, não se pode descartar a possibilidade dos indígenas de terem chegado a um entendimento com os seus interlocutores sem contar com a mediação de qualquer agência externa. Mas também é sabido que o contexto ao qual estamos nos referindo se encontrava marcado pelo acirramento dos conflitos intersocietários que acabaram resultando no extermínio de cerca de $50 \%$ da população Rikbaktsa ${ }^{9}$. Portanto, as chances de os autóctones encontrarem uma solução pacífica para as dificuldades que eles vinham enfrentando eram bastante limitadas, o que acabava criando um ambiente altamente favorável para a participação daquele seu enigmático "ancestral" no processo de negociação com os seringueiros.

Por outro lado, não se pode também afirmar que a chegada dos jesuítas ao vale do Juruena tenha representado uma solução para todos os problemas que assolavam o cotidiano do povo Rikbaktsa. Durante as nossas visitas às suas aldeias, coletamos o depoimento de algumas pessoas que

\footnotetext{
${ }^{9}$ Segundo o Pe. José de Moura, a população Rikbaktsa chegava em torno de 500 índios, antes da guerra contra os seringueiros; depois aquele grupo foi reduzido a aproximadamente 250 indivíduos, após o seu contato com as frentes extrativistas. (SILVA, 1975, p. 07)
} 
relataram as dificuldades que a presença dos padres acabou atraindo para a vida delas. É o caso, por exemplo, dos relatos feitos por Ernesto Waikopata, morador da aldeia Curva. Ao recordar os primeiros encontros que ele teve com o Pe. João Dornstauder e, sobretudo, ao descrever as experiências relacionadas à sua passagem pelo internato de Utiariti ${ }^{10}$, o nosso interlocutor teceu várias críticas ao regime disciplinar imposto pelos missionários, embora tenha reconhecido também alguns benefícios que a Missão acabou lhe proporcionando. Ouçamo-lo:

Naquela época, a gente tinha perdido os pais. Daí fomos levados para o internato de Utiariti. Eu tinha uns 10 ou 12 anos, então já tinha um pouco de noção das coisas. A gente aprendeu muitas coisas com os padres. Só que lá as coisas eram bastante rígidas, porque o sistema deles é bem diferente do nosso. Lá a gente não podia falar em nosso próprio idioma, tinha que falar só no português. E se a gente teimava, recebia castigo. Então tinha que andar na linha do jeito que eles queriam. Mas também foi bom, porque eu aprendi a ler, a escrever e fazer várias coisas. (Waikopata. Entrevista concedida em março de 2016).

De modo semelhante, deu-se também com Albano Mutzie. Ele nos disse que morava com a sua avó materna numa "maloca" situada entre o rio do Sangue e o Arinos, quando conheceu o Pe. Dornstauder. Revelou-nos que o seu primeiro encontro com o missionário foi marcado por um misto de espanto e de alegria. $\mathrm{Na}$ época da pacificação, o nosso entrevistado era muito jovem e nos conta que ele ficou bastante apreensivo com a chegada daquele sujeito estranho à sua aldeia, pois receava que pudesse se tratar de alguém mal intencionado. Até porque já tinha perdido vários dos seus entes queridos nos ataques promovidos pelos seus inimigos. Mas algo lhe dizia que aquele homem era diferente e isso o levou a adotar a seguinte atitude:

\footnotetext{
${ }^{10} \mathrm{O}$ internato de Utiariti era um lugar para onde os jesuítas conduziam os autóctones, sobretudo, os jovens e as crianças, oferecendo-lhes abrigo e submetendo-os a um rígido regime disciplinar, com o objetivo de alfabetizá-los e instruí-los a se tornarem cristãos, conforme os dogmas e os preceitos observados pela Igreja católica. Vale destacar ainda que a maioria dos alojados havia perdido os seus pais, durante os confrontos travados contra os seringueiros.
} 
Aos poucos fui chegando mais perto dele, apesar de ter sido alertado pela minha avó para fugir de gente estranha. Mas parecia que ele era gente do bem, porque não tinha armas e nem deu sinal de que pretendia nos atacar. Ele não sabia o nosso idioma e nem eu conhecia a língua dele, mas daí a gente começou a se falar através de gestos. Levei o padre até a nossa maloca, porque a minha avó estava deitada numa rede já bem ruim e precisava de ajuda. Daí ele aplicou uma injeção nela e depois de algum tempo foi embora. Eu não esqueço o que o padre fez por nós, porque ele foi muito bom. Apareceu na hora certa, quando a gente mais precisava. (Mutzie. Depoimento coletado em março de 2016).

As experiências relatadas por Albano não deixam dúvidas sobre o lugar de destaque ocupado pelo Pe. João Dornstauder na trajetória dos Rikbaktsa. Sob uma perspectiva religiosa, dir-se-ia que a presença dele na vida dos autóctones foi algo "providencial", frente às dificuldades pelas quais o povo estava passando naquele momento. De acordo com o Albano, o padre ajudou a salvar a vida de muitos índios, com os medicamentos que ele costumava carregar consigo durante as suas viagens.

Ora, basta recordar o exemplo exposto por Albano Mutzie, quanto aos cuidados dispensados pelo missionário à avó do nosso entrevistado. Se não fosse o religioso ter aparecido em sua aldeia naquela ocasião, talvez aquela senhora não tivesse conseguido sobreviver por muito tempo! Tudo isso fez com que os Rikbaktsa passassem a admirá-lo cada vez mais, passando a considerá-lo como um membro da própria comunidade: "Mùigynani” (PACINI, 1999, p. 59). E não deixa de ser interessante essa forma como os Rikbaktsa captaram esse missionário e outros ao seu favor; dizendo de outra forma, eles também souberam pacificar os missionários ao seu favor.

Por fim, queremos trazer à tona mais um exemplo que ajuda a ilustrar a forma como os Rikbaktsa concebem algumas situações relacionadas ao processo de pacificação conduzido pelos jesuítas. Na verdade, trata-se de uma experiência que se deu conosco há cerca de dez anos, quando tivemos a oportunidade de realizar a nossa primeira visita a algumas aldeias daquele povo. $\mathrm{Na}$ ocasião, apresentaram-me a um membro da comunidade chamado 
Roque Maekata, ex-cacique da aldeia Barranco Vermelho. Lembro-me que aquele simpático ancião recebeu-me de maneira muito cordial, levando-me até sua casa para tomar chicha de patuá e comer peixe frito com beiju de mandioca. Enquanto o estômago ia se servindo com essas deliciosas iguarias, a minha mente ia se abastecendo com as novidades proporcionadas por aquele inesquecível encontro.

Durante a conversa, Roque nos revelou que há vários anos ele mantém o hábito de anotar os principais eventos que acontecem no decorrer do seu dia a dia, registrando-os em seus diários. Com essa outra grata surpresa, perguntei-lhe de onde veio a inspiração para fazer aquilo e ele me falou que havia aprendido aquele método com os padres jesuítas.

Em seguida, entrou em seu quarto e voltou de lá trazendo uma caixa cheia de cadernos, a fim de confirmar o que acabara de nos dizer. Ao manusear algumas páginas daqueles documentos, percebi que realmente se tratava de anotações ligadas aos acontecimentos do seu cotidiano. Por fim, confidenciou-me que, ao final daquele dia, pretendia registrar também aquele nosso encontro, a fim de que ele não viesse a cair no esquecimento! Ora, como não ficar admirado diante desse tipo de revelação?

Ao interrogá-lo sobre o que pensava a respeito dos trabalhos realizados pelos padres católicos junto ao seu povo, fomos novamente surpreendidos pela elegância e fineza da resposta dada pelo nosso anfitrião. Achávamos, por exemplo, que ele teceria várias críticas aos missionários, devido às interferências exercidas pela presença deles no cotidiano daquela comunidade. Afinal, sabíamos que a ação promovida pelos jesuítas junto aos Rikbaktsa havia deixado profundas marcas em sua trajetória, tais como: o desestímulo ao uso de sua língua materna e a imposição de novos valores e costumes, visando transformá-los em sujeitos "civilizados"11. A seguir, tentarei reproduzir uma parte da sua fala, embora saibamos que o tempo às vezes se encarrega de apagar da nossa memória

\footnotetext{
${ }^{11}$ Devido à falta de clareza que esta palavra talvez possa suscitar entre nós, indicamos a leitura de duas obras que certamente contribuirão para uma compreensão mais ampla e detalhada acerca dos significados que pretendemos atribuir àquela expressão. Referimo-nos aqui às reflexões desenvolvidas por Norbert Elias, em seu livro O processo civilizador (vol. I e II), publicado há mais de vinte anos no Brasil pela editora Jorge Zahar.
} 
certas lembranças do passado. Apesar de não termos feito nenhum registro, naquela época, sobre as coisas que conversamos, acredito que tenham sido basicamente estas as palavras que nos foram ditas por aquele sábio líder indígena, a saber:

Olha, eu acho que a 'missão' teve um lado bom e outro ruim. O lado ruim é que a gente acabou perdendo um pouco da nossa cultura, e alguns até deixaram de falar a nossa língua, por causa das regras que havia lá no internato. Mas também teve um lado bom, porque a gente aprendeu a ler e a escrever, e isso ajudou o nosso povo a conhecer os seus direitos. Eu acho que, se não fosse isso, a gente nem teria conseguido a demarcação das nossas terras, porque isso aqui já foi resultado daquelas coisas que a gente aprendeu lá atrás com os missionários. Acho que se o nosso povo não tivesse sido 'amansado' pelo padre João, a gente ainda estaria vivendo como 'bicho' do mato ou talvez nem teria essa terra pra viver nela. (Maekata. Baseado num diálogo ocorrido em dezembro de 2005)

Como já foi dito, o relato que acabamos de expor é resultado de uma tentativa de reconstituir alguns trechos de um diálogo entabulado há vários anos entre nós e Roque Maekata, ex-cacique da aldeia Barranco Vermelho. Apesar das dificuldades encontradas para executarmos essa tarefa, podemos afirmar com toda a tranquilidade que o conteúdo ali reproduzido corresponde integralmente às informações que nos foram repassadas pelo nosso interlocutor. Quando tivemos aquela conversa, sequer imaginávamos que um dia ela seria retomada para cumprir um propósito de caráter acadêmico. $\mathrm{Na}$ verdade, só resolvemos incorporá-la em nosso trabalho devido à importância daquela narrativa dentro do contexto das análises que estamos procurando desenvolver acerca de alguns aspectos ligados à trajetória do povo Rikbaktsa.

De modo particular, interessa-nos destacar aqui a forma como Roque faz a sua avaliação sobre a presença dos jesuítas na trajetória do seu povo, construindo um discurso bastante equilibrado em torno das experiências relacionadas àquela intervenção "sócio-humanitária" ocorrida em 
suas vidas. Percebe-se que não há exageros em sua fala, ainda que ele tivesse vários motivos para se manifestar de um modo diferente sobre tal assunto. Afinal, a ação empreendida pelos missionários católicos acabou produzindo uma série de mudanças aparentemente indesejáveis sobre a sua organização interna, até com a introdução de novas crenças religiosas. Ou será que a sua adesão ao cristianismo se deu de forma livre e espontânea, isto é, fundada sobre um desejo manifestado pela maioria dos membros daquela comunidade?

A propósito, veremos que a incorporação da formação escolar no cotidiano dos Rikbaktsa também faz parte das heranças que lhes foram legadas pelos jesuítas, durante a sua passagem pelo internato de Utiariti. Até então, o referido povo recorria apenas aos métodos tradicionais, como a comunicação oral e o exemplo dos mais velhos, para promover a educação dos seus filhos e filhas (MELIÁ, 1979). A conquista das letras e seus mistérios têm alguns capítulos que serão abordados em outros trabalhos pela sua relevância. Aqui o espaço permite oferecer apenas uma breve exposição sobre a forma como os membros daquela comunidade concebem o processo de pacificação ao qual foram submetidos. Talvez os relatos expostos não contemplem a opinião de todos os Rikbaktsa, contudo podemos dizer que são generalizadas essas posturas. Por isso, possuem uma validade especial, visto que cada um daqueles depoimentos certamente nos ajuda a ter uma ideia sobre o modo como os Rikbaktsa enxergam e avaliam as ações promovidas pela Igreja Católica através dos jesuítas.

\section{Conclusão}

No decorrer deste trabalho, trouxemos à tona os resultados preliminares de uma pesquisa que estamos realizando sobre a comunidade indígena Rikbaktsa, cujo foco consiste em investigar como se deu o processo de escolarização desse grupo e de que forma seus membros concebem a presença da escola em seu cotidiano. Vale lembrar que, até há pouco tempo, esses índios nem imaginavam o que era educação escolar, pois permaneciam completamente isolados da sociedade nacional. De acordo com 
os nossos levantamentos, eles passaram a conhecer essa forma de ensino só a partir de 1957, através da sua passagem pelo antigo internato dos jesuítas em Utiariti...

Num primeiro momento, fizemos uma breve exposição em torno dos principais fatores que teriam motivado o processo de "pacificação" empreendido pelos missionários católicos junto aos Rikbaktsa. Vimos que esse povo se encontrava em situação de guerra contra as frentes extrativistas que haviam se instalado na região do vale do Juruena, resultando na morte de centenas de índios e seringueiros. Por essa razão, a Companhia de Jesus deu início às suas operações missionárias, a fim de promover a paz e a harmonia entre aqueles dois grupos. No entanto, sabe-se que tal projeto implicou também num gradativo e intenso processo de doutrinação religiosa dos autóctones, com o intuito de convertê-los à proposta anunciada pelos propagadores da fé cristã!

É dentro desse contexto, pois, que se insere o conjunto de atividades socioeducativas desenvolvidas pelos jesuítas que, um pouco mais adiante, viria a culminar na adesão dos Rikbaktsa ao processo de escolarização. Vale ressaltar que vários daqueles índios que frequentaram a escola de Utiariti acabaram se tornando professores, após o seu retorno às aldeias. Isso levou esses bravos guerreiros a mudar o seu modo de fazer guerra, trocando a borduna pela caneta! Porém, cumpre dar continuidade à nossa investigação, no sentido de tentar aprofundar as questões já levantadas, a fim de explicitar o significado da instituição escolar no âmbito da referida comunidade. 


\section{Referências}

ARRUDA, R. S. V. Os Rikbaktsa: mudança e tradição. São Paulo: PUC, 1992.

BRASIL, IBGE. Censo Demográfico, 2010, p. 153. Disponível em: <http://biblioteca. ibge.gov.br/visualizacao/periodicos/95/cd_2010_indigenas_universo.pdf $>$. Acesso em: 23 abr. 2016.

CAMINHA, P. V. de. Carta do “descobrimento” do Brasil. Porto Seguro, 1500.

DORNSTAUDER, J. E. Como pacifiquei os Rikbaktsa. Instituto Anchietano de Pesquisas: São Leopoldo, 1975.

GEERTZ, C. A Interpretação das Culturas. Rio de Janeiro: Guanabara: Koogan, 1989.

LIMA, N. T. Introdução à Rondônia de Edgard Roquette-Pinto. In: ROQUETTE-PINTO, Edgar. Rondônia: anthropologia-ethnographia. 7. ed. Rio de Janeiro: Fiocruz, 2005.

LUNKES, O. P. Origem, Lendas e Costumes dos índios Rikmakca. Estudos Leopoldenses. Separata. Ano XIII, v. 13, n. 48. 1978.

MARTINELLO, P. A "batalha da borracha” na segunda guerra mundial e suas conseqüências para o vale amazônico. São Paulo: Cadernos UFAC, 1988.

MELIÁ, B. Educação indígena e alfabetização. São Paulo: Edições Loyola, 1979.

PACINI, A. Pacificar: relações interétnicas e territorialização dos Rikbaktsa. 1999. Dissertação (Mestrado em Antropologia Social) - PPGAS, Museu Nacional, Universidade Federal do Rio de Janeiro, Rio de Janeiro. 1999, 261 p.

PACINI, A. Um artífice da paz entre seringueiros e índios. São Leopoldo: Unisinos, 2015.

PEREIRA, P. I. G. Juína, a Rainha da Floresta: Uma história sob o olhar Rikbaktsa. Disponível em: <http://www.biblioteca.ajes.edu.br/arquivos/monografia_20150821204931. pdf >. Acesso em: 26 mar. 2016.

PIVETTA, D. Amazônia Meridional: território deflagrado, educação pacificadora. 1999. Tese (Doutorado em Educação Pública) - PIPGE, Instituto de Educação, Universidade Federal de Mato Grosso, Cuiabá/MT. 1999, 249 p.

RODRIGUES, A. D. Línguas Brasileiras. Para o Conhecimento das Línguas Indígenas. Loyola: Campinas, 1986.

SILVA, J. M. Como pacifiquei os Rikbaktsa. Instituto Anchietano de Pesquisas: São Leopoldo, 1975. 


\section{INSTITUIÇÃO ESCOLARE \\ DIFERENÇAS: ALGUMAS CONSIDERAÇÕES}

\section{Patrícia Dias (sEDUc/MT )}

\section{Introdução}

Nesse texto discute-se o conceito de "diferença" numa abordagem antropológica e educacional no cenário das diferentes tipologias da instituição escolar brasileira. Sabemos que, historicamente, a educação escolar no Brasil foi conduzida com propósitos de impor a cultura dominante (ocidental), buscando a integração da sociedade nacional.

O interesse pela temática "escola e diferença" constitui um desdobramento de pesquisas realizadas junto ao Programa de Pós-Graduação em Educação da Universidade Federal de Mato Grosso (PPGE/UFMT), especificamente no âmbito do Grupo de Estudos e Pesquisa em Educação Escolar Indígena (GEPEEI). Nesse contexto, foi possível produzir uma reflexão a respeito das diferenças e educação escolar, na tentativa de atender a demanda da diversidade brasileira, exigida por meio de movimentos sociais, dos ditos grupos minoritários.

Para Candau (2011, p. 242), a realidade não só brasileira, mas principalmente da América Latina, apresenta características bem particulares, uma vez que é “[...] caracterizada por uma cultura pluridentitária, formada por diferentes grupos sociais, étnicos, das áreas urbanas e rurais, constituindo, assim, uma realidade multicultural".

As diferenças são então concebidas como realidades sócio históricas, em processo contínuo de construção-desconstrução-construção, dinâmicas, que se configuram nas relações sociais e estão atravessadas por questões de poder. São constitutivas dos indivíduos e dos grupos sociais. Devem ser reconhecidas e valorizadas positivamente no que 
têm de marcas sempre dinâmicas de identidade, ao mesmo tempo em que combatidas as tendências a transformá-las em desigualdades, assim como a tornar os sujeitos a elas referidos objeto de preconceito e discriminação. (CANDAU, 2011, p. 245).

Durante muito tempo, “[...] o direito à identidade virou sinônimo de direito a diferença, que acabou reforçando a hierarquia e práticas discriminatórias" (FERRARI, 2000, p. 95). Para o mesmo autor, as "diferenças devem ser entendidas como pluralismo, sem defesa de hierarquia". Tendo presente essa problemática, o presente texto busca fazer uma breve contextualização a respeito da diferença e educação escolar e, mais precisamente, sobre as diferentes tipologias de escolas brasileiras, presente no censo escolar.

\section{Breve contextualização sobre diferenças e educação escolar}

Para Ferrari (2000, p. 88), "Foi durante a modernidade que se fortaleceu a certeza de que os seres humanos não eram iguais. Não eram iguais, não nasciam iguais e não deveriam ser tratados como iguais". De acordo com Sacristán (2001, p. 124), "a modernidade abordou a diversidade de duas formas básicas: assimilando tudo que é diferente a padrões unitários ou segregando-o em categorias fora da normalidade dominante".

No campo da antropologia, o conceito de cultura e o relativismo antropológico foram fundamentais para transformação das diferenças, “[...] que deixaram de ser explicadas pela natureza e passaram a ser entendidas como diversidades e costumes" (FERRARI, 2000, p. 89).

A antropologia, como ciência da modernidade, coloca seu aparato teórico construído no passado, com possibilidade de, no presente, explicar e compreender os intensos movimentos provocados pela globalização: de um lado, os processos homogeneizantes da ordem social mundial e, de outro, contrariando tal tendência, a reivindicação das singularidades, apontando para a constituição da humanidade como una e diversa. (GUSMÃO, 2008, p. 48). 
Nesse campo de tensão, Gusmão (2008) defende que a trajetória da antropologia segue por duas vias: a primeira, que tem sido a de avaliar as diferenças sociais, étnicas, culturais, entre outras, com objetivo de proporcionar alternativas de intervenção a respeito da realidade social de modo a não negar as diferenças; e a segunda, não seria a tradição antropológica suficiente para dar conta do contexto político das diferenças e, assim, estaria superada em seus propósitos.

Para mesma autora, o palco da antropologia da educação, que foi bastante ativo entre os anos de 1920 e 1930, e assim persistiu durante todo o século XX, “[...] mudando sua roupagem (e muito pouco seu conteúdo) de acordo com as conjunturas sociais e políticas de cada momento” (ibid.).

Segundo Gusmão (2008, p. 50 - 51):

Significativa nessa antropologia foi a tentativa de "normalizar" os sistemas educativos, em busca de uma "funcionalidade" entre a escola e a sociedade, segundo um modelo "desejável" de escola. Tal perspectiva admitia, porém, a educação além da escola, pois dizia respeito à formação da personalidade e à socialização dos indivíduos, necessárias à integração e à acomodação à sociedade e a seus valores.

Ao abordar educação e diferenças, Marques (2012, p. 103) ressalta que "a escola, apesar de ser um espaço onde as diferenças sempre coexistiram, nem sempre reconheceu sua existência ou a considerou na sua complexidade”. Desse modo, historicamente, a instituição escolar não se pauta nas diferenças, "[...] ela considera os diferentes e não as diferenças. Pensando nos 'diferentes', nos 'estranhos', nos 'outros', a escola acaba por propiciar o processo de normalização de seus alunos e de suas alunas” (MARQUES, 2012, p. 106).

Nesse contexto,

A instituição escolar, como contemporânea desse discurso, contribuiu para produzir diferenças e, principalmente, desigualdades, exercendo 
uma ação distintiva. Inicialmente, esta distinção se fazia entre os que tinham acesso a ela e os que ficavam fora dela. Posteriormente, a distinção passou a ser feita dentro do próprio sistema educacional, através de variados mecanismos de classificação, ordenamento e hierarquização. (FERRARI, 2000, p. 89 - 90).

Sabemos que os diversos enfoques dados à questão das diferenças têm provocado tensões e conflitos. Atualmente, "ser diferente não significa mais ser o oposto do normal, mas apenas ser diferente"(MARQUES, 2012, p. 108). A partir de 1970, o discurso das diferenças tomou novas roupagens e faz parte do cotidiano dos grupos sociais minoritários. De acordo com Candau (2011, p. 241),

\begin{abstract}
As diferenças culturais - étnicas, de gênero, orientação sexual, religiosas, entre outras - se manifestam em todas as suas cores, sons, ritos, saberes, sabores, crenças e outros modos de expressão. As questões colocadas são múltiplas, visibilizadas principalmente pelos movimentos sociais, que denunciam injustiças, desigualdades e discriminações, reivindicando igualdade de acesso a bens e serviços e reconhecimento político e cultural.
\end{abstract}

As diferenças, no âmbito da educação, também “[...] se explicitam cada vez com maior força e desafiam visões e práticas profundamente arraigadas no cotidiano escolar" (CANDAU, 2011, p. 241). Nesse contexto, buscou-se relacionar a educação com a pluralidade de culturas, raças, diferentes povos (indígenas/quilombolas), gênero, religiosidades, entre outras dimensões identitárias. Esses temas, principalmente a partir de 1990, se tornaram essenciais no campo da pesquisa científica educacional e nos cursos de formação e aperfeiçoamento de professores em todo o país. 
O movimento conhecido como multiculturalismo crítico $^{1}$, que se constitui na educação brasileira, também a partir de 1990, contribuiu para reflexão a respeito da instituição escolar voltada a diversidades e à luta pelo direito à "diferença”, vinculados às reivindicações de grupos historicamente excluídos na busca de práticas pedagógicas que visem à formação identitária desses grupos. Para Candau (2011, p. 241),

A cultura escolar dominante em nossas instituições educativas, construída fundamentalmente a partir da matriz político-social e epistemológica da modernidade, prioriza o comum, o uniforme, o homogêneo, considerados como elementos constitutivos do universal. Nesta ótica, as diferenças são ignoradas ou consideradas um "problema" a resolver.

Considerando o contexto histórico da educação no Brasil, que por muitos anos priorizou a reprodução da cultura "dominante" em um cenário multicultural, torna-se fundamental discutir criticamente os processos de produção das identidades culturais, visando uma prática pedagógica comprometida com os grupos culturalmente e socialmente excluídos. Assim, de acordo com Candau (2012, p. 236)

A presença de grupos socioculturais diversos nos cenários públicos, tanto no âmbito internacional como no Brasil, tem provocado tensões, conflitos, diálogos e negociações orientadas à construção de políticas

\footnotetext{
${ }^{1}$ Para McLaren (1994), há diferentes concepções de multiculturalismo: (1) O multiculturalismo conservador ou empresarial, que é apresentado como o projeto de universalização e superioridade da cultura branca, respaldado nas teorias evolucionistas do século XIX; (2) O multiculturalismo liberal humanista, que tem como principal característica a apropriação humanística, se apoia na crença do princípio de igualdade independentemente de questões de etnia, gênero ou sexualidade, em que todos podem competir igualmente em uma sociedade capitalista. (3) $\mathrm{O}$ multiculturalismo liberal de esquerda defende as diferenças no tocante às raças, classe, gênero e sexualidade, no entanto, essencializa-as ao compreendê-los como formas de significações de seus contextos históricos culturais; e (4) multiculturalismo crítico, que é defendido pelo autor como a necessidade de uma negociação cultural que se dá em terreno "contestado", marcado por processos históricos, por relação de poder e pela ideologia. Para McLaren (1994), o multiculturalismo crítico exerce uma pedagogia de resistência, interrogando os sistemas culturais estabelecidos em uma lógica fixa e unitária. Segundo Candau (2002), as "raízes" do multiculturalismo podem ser encontradas nos movimentos sociais, mais especificamente nos movimentos étnicos que ocorreram nos Estados Unidos, durante a década de 60, quando estudantes, líderes religiosos e negros do Sul resolveram levar adiante a luta por igualdade de exercício dos direitos civis.
} 
públicas que focalizem estas questões. Em cada contexto esta problemática adquire uma configuração específica, articulada com as diversas construções históricas e político-culturais de cada realidade.

Considerando a grande diversidade da população e incentivados pelas manifestações dos ditos "excluídos", nos últimos anos, várias políticas públicas, leis e resoluções foram criadas a fim de atender as demandas dentro e fora da escola. No entanto, criar leis específicas contemplando a diversidade nas escolas não foi suficiente, foi preciso também (re)criar escolas específicas, com o objetivo de atender as demandas e os interesses dos vários povos que compõem a sociedade brasileira.

\section{As tipologias de escola classificada pelo Inep no Censo Escolar}

As escolas indígenas, quilombolas, do campo, com "direito de serem específicas", são exemplo de instituições fruto da reivindicação de grupos socialmente excluídos. A necessidade de ressignificar as instituições escolares em contextos específicos/tradicionais (Terras quilombolas, Terras indígenas e áreas de assentamentos) se torna cada vez mais urgente, uma vez que essas são garantidas na Constituição vigente e leis subsequentes.

Sem pretender qualquer levantamento exaustivo, destaco algumas características tipológicas das escolas, presentes no censo escolar, que podem ser sintetizadas nos seguintes agrupamentos: Escola comum, escolas de atendimento especial, escolas em áreas de assentamento, escolas quilombolas e escolas indígenas, essa última, como cenário principal deste estudo, terá maior ênfase.

\subsection{Escola “comum"}

A escola "comum" é compreendida aqui como a instituição escolar que atende a comunidade em geral, não situada em territórios específicos/ tradicionais. As escolas comuns podem ser urbanas ou rurais; de acordo com INEP (2015), em sua maioria, são urbanas, e oferecem vagas em toda a educação básica. 
De acordo com os dados do censo escolar, INEP $(2015)^{2}$, pode-se afirmar que mais de $80 \%$ dos estudantes da educação básica estão matriculados em escolas públicas em todo o país ${ }^{3}$.

No Brasil, a educação básica está organizada por modalidades, a saber: ensino regular, Educação de Jovens e Adultos (EJA) e educação especial. O Ensino regular compreende a educação infantil (creche e pré-escola), ensino fundamental (anos iniciais e finais) e ensino médio, que pode ser concomitante com a educação profissional (ensino técnico). A EJA oferta escolarização para jovens fora da faixa etária para cursar o ensino regular, e para adultos, no nível fundamental e médio. $\mathrm{Na}$ educação especial, atendem-se estudantes com deficiências em salas comuns (inclusão) ou em classes exclusivas (INEP, 2015).

A educação básica no Brasil pode ser dividida em duas grandes áreas administrativas, escola pública e escola privada. As escolas públicas estão sob a administração Federal, Estadual e Municipal. As redes municipais são responsáveis por quase metade das matrículas $(46,4 \%)$, o equivalente a 23.215.052 alunos, seguida pela rede estadual, que atende a $35,8 \%$ do total, 17.926.568 alunos; a rede federal, com 290.796 matrículas, participa com $0,6 \%$ do total (INEP, 2014).

A implantação do modelo de escola gratuita no país seguiu o exemplo europeu de escolarização em massa, que ocorreu a partir da segunda metade do século XIX, e se apresentou como um modelo de abrangência global, com aspectos específicos, tais como: a obrigação escolar, a gratuidade do ensino (de responsabilidade do Estado), a pátria como princípio norteador da cultura escolar, a educação popular idealizada como um projeto para a concretização de uma nova ordem social.

Havia a necessidade de uma formação para o novo homem, visando o "progresso" no Brasil, e nota-se a escola como a instituição necessária para os

\footnotetext{
${ }^{2}$ Neste trabalho, utilizaram-se dados do censo escolar de 2014 e 2015; como os relatórios demoram a ser publicado pelo INEP, de 2015 temos apenas dados estatísticos gerais a respeito da educação escolar, e de 2014, foi disponibilizado o resumo técnico completo como dados de todas as escolas, indígena, quilombola, da educação no campo e educação especial.

${ }^{3} \mathrm{O}$ número de matrículas na educação básica, na rede pública (2014), somou 40.680 .590 $(81,7 \%)$ dos alunos matriculados, e as escolas privadas registrou cerca de 9.090.781 (18,3 \%) matrículas, no mesmo período. (INEP, 2015).
} 
avanços pretendidos. Pode-se afirmar que a escola pública brasileira surgiu como estratégia da elite republicana paulista e constituiu um exemplo escolar a ser implementado por outros estados do país. No entanto, mesmo tento como objetivo a escolarização das ditas camadas populares, a escola pública, no início do século XX, contemplava uma pequena parcela da população.

Com a Revolução Industrial, a prioridade seria a educação dos sujeitos pertencentes aos setores ligados ao trabalho urbano; moradores do campo, pobres e negros não foram contemplados. Por volta de 1920, os "excluídos" do sistema escolar e da sociedade começaram a reivindicar o seu espaço. Para Saviani (2006), o Manifesto dos Pioneiros da Educação Nova se apresenta como um instrumento político, expressando a posição de um grupo de educadores que se juntaram na década de 1920, e que viram na Revolução de 1930 a oportunidade de vir a exercer o controle da educação brasileira.

O manifesto dos Pioneiros é um marco de referência "[...] que inspirou as gerações seguintes, tendo influenciado, a partir de seu lançamento, a teoria da educação, a política educacional, assim como a prática pedagógica em todo o país" (SAVIANI, 2006, p. 35).

Outro marco da educação pública no país, sem dúvida, foi o rompimento do Estado com a Igreja. Seguindo o modelo de educação em outros países (europeus), a escola brasileira se tornou laica, provendo um novo arranjo curricular na instituição, que passou a agregar novas matérias de instrução, sem priorizar as tradições da igreja católica. No entanto, essa ação não impediu que a escola continuasse a ofertar um ensino monocultural com propósitos, ideais e cultura da "classe dominante".

Romper com a cultura dominante, que está arraigada no contexto das escolas públicas, tem sido um grande desafio. Para Freire (2005), em sociedades governadas por grupos e classes dominantes, se faz necessário que a educação seja "prática de liberdade". Trata-se de pensar uma pedagogia do próprio sujeito, e não para ele. Uma educação libertadora não pode ser compatível com uma pedagogia da prática de dominação.

Embalada pelo discurso contra a prática de dominação, apoiada pelos movimentos sociais em diversas esferas da sociedade, em âmbito nacional e internacional, nasce a Constituição Federal de 1988, que garantiu uma 
educação gratuita a todos os brasileiros, reconhecendo a importância das culturas, favorecendo uma educação para a diversidade brasileira.

A partir da Constituição vigente e, mais especificamente, no campo da educação, com a elaboração da LDBEN (9.394/96), diversos outros desdobramentos ocorreram no âmbito do tratamento da diversidade sociocultural na educação em todo o país.

Desse modo, foram criadas leis específicas para atender demandas, tais como, a Educação Indígena (Resolução no 3/1999), a Educação de Jovens e Adultos - EJA (Resolução no 1/2000), a Educação Especial (Resolução no 2/2001), a Educação do Campo (Resolução no 1/2002), entre outras. Há de destacar, também, a Lei no 10.639/2003, que tornou obrigatório o ensino da cultura afro-brasileira, na instituição escolar básica, e a Lei 11.645/2008, que tornou obrigatório o ensino da cultura afro-brasileira/africana e indígena nas escolas, entre outras leis e políticas públicas que buscam atender as especificidades e/ou diversidade dentro das instituições escolares e fora dela.

\subsection{Escolas exclusivas para educação especial}

De acordo com Miranda (2003), a história da educação escolar para pessoas com deficiências ${ }^{4}$ pode ser classificada em quatro fases, a saber: A primeira marcada pela negligência, durante a era pré- cristã, em que havia uma ausência total de atendimento. A segunda fase ocorreu durante o século XVIII até meados do século XIX, em que se constata a institucionalização da educação especial: os indivíduos que apresentavam deficiência eram segregados e abrigados em instituições residenciais. A terceira fase compreende o período de anos finais do século XIX e meados do século XX, marcado pelo desenvolvimento de escolas e/ou classes especiais na instituição escolar pública, com objetivo de ofertar à pessoa deficiente uma educação à parte. A quarta e última fase, por volta da década de 1970, busca a integração social dos indivíduos que apresentavam deficiência, em ambientes escolares.

\footnotetext{
${ }^{4}$ Embora o censo escolar (2015) utilize a terminologia "educação especial", optamos por utilizar alunos com deficiências em vez de alunos com necessidades especiais, de acordo com o Decreto no 6.949, de 25 de agosto de 2009
} 
No Brasil, o atendimento para pessoas deficientes iniciou durante o período Imperial, com a criação de duas instituições: o Imperial Instituto dos Meninos Cegos, em 1854, e o Instituto dos Surdos Mudos, em 1857. Posteriormente, foram criadas outras instituições, a princípio por meio de iniciativas privadas. Entre as instituições de maior destaque no país estão a Pestalozzi ${ }^{5}$ e as Associações de Pais e Amigos dos Excepcionais - APAEs ${ }^{6}$. Embora esses estabelecimentos contassem com o subsídio do Estado, somente a partir de 1950 ocorrem iniciativas do governo brasileiro visando à educação de pessoas com deficiência ${ }^{7}$.

Por meio de campanhas, em 1957, foi contemplada a educação para surdos; logo depois, em 1958, lançou-se a campanha para a educação dos deficientes visuais e, em 1960, a educação para os deficientes mentais. Há de destacar, ainda, a primeira Lei de Diretrizes e Bases da Educação Nacional, Lei no 4.024, de 20 de dezembro de 1961, oficializando a educação especial na legislação do ensino. E o primeiro órgão federal destinado à organização da educação para pessoas com deficiência, em âmbito nacional, o Centro Nacional de Educação Especial - CENESP, foi criado em 1973 (RAFANTE, 2015).

Atualmente, a política de educação para pessoas com deficiências, adotada pelo Ministério da Educação, estabelece que se desestimule a criação de escolas e salas exclusivas, e que a educação inclusiva seja prioridade; $56,6 \%$ das escolas brasileiras têm alunos com deficiência incluídos em turmas regulares (INEP, (2015).

Essa mudança está fundamentada na educação especial, na perspectiva da "integração" do aluno com deficiência, visando à oferta de vagas na classe/escola comum do ensino regular, valorizando as diferenças e atendendo às necessidades educacionais de cada aluno. Constatou-se um aumento de $85,8 \%$, no número de alunos incluídos em classe/escolas comuns, somando 655.375 mil matrículas em 2014; consequentemente,

${ }^{5}$ Instituição fundada no Brasil pela professora Helena Antipoff, em 1932, em Minas Gerais (RAFANTE, 2015).

${ }^{6}$ A APAE foi criada em 1954, no Rio de Janeiro.

7 Disponível em: <http://peei.mec.gov.br/arquivos/politica_nacional_educacao_especial.pdf>. 
nas classes/escolas exclusivas, houve queda de 54,8\% no número de matrículas, no mesmo período (INEP, 2015).

A educação escolar inclusiva para pessoas com deficiências tem apresentado alguns desafios, como a falta de acessibilidade das escolas e a falta de profissionais qualificados no atendimento nas escolas. Estudos têm apontado a necessidade de fortalecer a formação de professores e a articulação entre docentes, gestores, familiares e profissionais de saúde para melhor atender os alunos com deficiência nas escolas ${ }^{8}$.

\subsection{Escolas em área de assentamento (educação do campo)}

A educação escolar do campo, a partir de 1980, ganha novo significado por meio de movimentos sociais, especialmente ligados ao Movimento dos Trabalhadores Rurais Sem Terra (MST). Anteriormente, raras foram as políticas públicas criadas para atender a educação dos moradores do campo, embora, até a década de 1980, a maioria da população vivesse no meio rural (JESUS, 2011).

A educação escolar, pensada com objetivo de valorizar o espaço rural, se tornou essencial para aproximar a educação com o espaço em que se vive, buscando a permanência do estudante no campo. A proposta de um projeto diferenciado (alternância) é destacada pela educação do campo, pois tem a preocupação de proporcionar a formação sem desvincular o aluno da área rural, do seu meio familiar e cultural, além de trabalhar os confrontos dos saberes científicos com os saberes cotidianos na interface dos diferentes espaços (JESUS, 2011).

Para Souza (2006), há de se problematizar os termos educação "no" e "do" campo, visto que a educação "no campo" está vinculada, especificamente, à localização da escola/ensino no espaço rural. Já a educação "do campo", conforme Souza, "[...] é uma proposta que tem sido defendida pelos sujeitos sociais organizados, como forma de garantir interesses culturais, econômicos e sociais da população trabalhadora no campo" (2006, p. 62).

\footnotetext{
8 Disponível em: <http://novaescola.org.br/formacao/palavra-especialista-desafios-educacao-inclusiva-foco-redes-apoio-734436.shtml>
} 
A educação de maior destaque no campo acontece por meio de instituições como as Escolas Família Agrícola - EFAs em todo o país. São escolas de Ensino Fundamental e Médio e, às vezes, de Ensino Técnico; no geral, essas instituições funcionam em regime de alternância, atendendo estudantes, em sua maioria, filhos de agricultores, muitos deles assentados da Reforma Agrária (JESUS, 2011).

O INEP (2014), ao analisar os dados da escola do campo, no período de 2007 a 2013, apontou uma queda de 7,9\% no número de matrículas total; houve queda em todas as etapas do ensino: Educação Infantil, anos iniciais e finais do Ensino Fundamental, no Ensino Médio, na Educação de Jovens e Adultos - EJA e no ensino profissionalizante.

\subsection{Escolas Quilombolas}

As políticas públicas, especificamente para as escolas remanescentes de quilombo, são recentes. Embora o tema educação específica para a diversidade estar garantido na Constituição Federal (1988) e na LDBEN (1996), somente com a Lei Federal no 10.639/2003, que tornou obrigatório o ensino da cultura afro-brasileira e africana na educação básica, foi possível a ampliação do debate público e no âmbito acadêmico a respeito da educação em comunidades quilombolas, o que contribuiu para reflexões acerca da necessidade de aproximar o currículo escolar com os saberes, cultura e tradição em escolas em áreas remanescente de Quilombo (MAROUN, 2016).

Além da Lei Federal citada, a educação quilombola encontra amparo legal em outras políticas de afirmação, como: a Convenção da Organização Internacional do Trabalho - OIT (Decreto Federal no 5.051/2004); o Decreto Federal no 6.040/2007 (Plano Nacional de Desenvolvimento de Populações Tradicionais); a Resolução no 7/2010 do CNE/CEB, que garante a educação diferenciada; a Resolução no 4/2010 do CNE/CEB, que institui as diretrizes para a educação básica e faz menções específicas para escolas em áreas remanescentes de Quilombo; e as Diretrizes Curriculares Nacionais para a Educação escolas Quilombola (2012). (MAROUN, 2016). 
No censo escolar, as matrículas em escolas remanescentes de Quilombo têm aumentado no decorrer dos anos em todas as etapas no ensino regular; no ano de 2013, houve 227.430 alunos matriculados (INEP, 2014). Estudos e pesquisas científicas recentes têm apontado a necessidade de maior aproximação entre currículo escolar e a cultura dessas comunidades tradicionais.

\subsection{Escolas indígenas}

A população indígena brasileira vem sofrendo duros golpes desde a chegada dos colonizadores nessa terra, em que diversos povos foram completamente extintos. Numa visão colonialista, o desaparecimento dos povos indígenas passou a ser aceito como uma contingência histórica, algo a ser lamentado, porém inevitável. Contrariando os interesses da colonialidade, no cenário atual, é possível notar mudanças significativas, como o aumento populacional indígena expresso nos últimos três censos demográficos (1991, 2000 e 2010).

A primeira vez que a população indígena apareceu no censo demográfico nacional foi em 1991. Em 2000, o censo apontou um crescimento expressivo dos povos indígenas, que passou de $0,2 \%$ da população total para $0,4 \%{ }^{9}$. O censo de 2010 contabilizou 817.963 mil indígenas, representando 305 diferentes povos ${ }^{10}$, e 274 línguas faladas, em que 17,5\% dos indígenas brasileiros não falam a língua portuguesa (IBGE, 2010).

No que se refere à legislação para a educação escolar indígena, os principais marcos podem ser assim sintetizado: a Constituição Federal de 1988 que, entre outros direitos, garante a educação diferenciada; a Convenção e Resolução no 169/1989 da Organização Internacional do Trabalho (OIT)

\footnotetext{
${ }_{9}^{9}$ Há de considerar, além do aumento da taxa de natalidade, o método utilizado pelo IBGE para realizar a pesquisa: a partir do censo de 2000 foram considerados alguns casos específicos, como autodeclaração, sem considerar o local habitado pelos indígenas, pois muitos deles são moradores da área urbana em todo o país.

${ }^{10}$ A FUNAI também registra 69 referências de índios ainda não contatados, além de existirem grupos que estão requerendo o reconhecimento de sua condição indígena junto ao órgão federal indigenista. Disponível em: <http://www.funai.gov.br/index.php/indios-no-brasil/quem-sao>.
} 
aponta algumas disposições gerais acerca dos Povos indígenas; o Decreto Federal no 26/1991, que tirou da FUNAI a incumbência de comandar a educação escolar indígena e atribui ao Ministério da Educação (MEC) a competência de coordenar as ações referentes à educação escolar, em todos os níveis e modalidades de ensino; a Lei de Diretrizes e Bases da Educação Nacional (LDBEN) no 9.394/1996 que, coerente com a Constituição vigente, reconhece a diversidade cultural e estabelece a educação bilíngue e intercultural para os povos indígenas; o Referencial Curricular Nacional para as Escolas Indígenas (RCNEI), de 1998, reconhece as especificidades das escolas e orienta que as elas sejam pensadas, ressignificadas (em seus conteúdos/currículo) pelos próprios povos indígenas; a Resolução $\mathrm{CNE} / \mathrm{CEB}$ no 3/1999 fixa as Diretrizes Nacionais para o Funcionamento das Escolas Indígenas; o Parecer CNE/CEB no 14/1999 estabelece as Diretrizes Curriculares Nacionais da Educação Escolar Indígena; a Lei 13.005/2014 - Plano Nacional de Educação (PNE) apresenta objetivos e metas para a educação escolar indígena, respeitando o que assegura as leis vigentes citadas.

Os direitos garantidos na lei brasileira representam uma importante conquista histórica dos povos indígenas e de seus aliados, fruto de muita luta e sacrifícios. Para Luciano (2013, p. 1), o papel dos movimentos e organizações de professores e lideranças indígenas foi fundamental para o estabelecimento dos direitos e "precisa ser também para sua efetivação nas práticas cotidianas nas escolas e nas aldeias indígenas"

No entanto, os povos indígenas contemporâneos têm exigido a participação na elaboração das políticas públicas, a fim de que elas possam contemplar e representar seus próprios interesses. Por anos, as leis que regem a educação, saúde, território etc. dos povos indígenas foram elaboradas sem a participação ou a opinião dos próprios grupos tradicionais. Nota-se a importância do posicionamento dos ameríndios nos movimentos sociais para a elaboração de políticas públicas como estratégias para superar o modelo de escola integracionista, fundamentada pela colonialidade, historicamente presente no contexto indígena brasileiro.

A escola, nos moldes de hoje, se constitui como um espaço arquitetado pela sociedade moderna que, ao longo dos últimos trinta anos, vem 
sofrendo mudanças significativas devido a ações coletivas, organização e movimentos de luta, e reivindicação da população indígena por uma participação igualitária nas formulações, propostas e práticas para uma educação que realmente atenda às suas demandas.

$\mathrm{Na}$ Tabela que segue, são apresentados dados do censo escolar referente ao período de 2007 a 2013, número de matrículas da educação básica indígena no Brasil, por modalidade de ensino.

Tabela 1 - Número de Matrículas de Educação Indígena por Modalidade e Etapa de Ensino - Brasil - 2007-2013

\begin{tabular}{|c|c|c|c|c|c|c|c|c|c|}
\hline \multirow{4}{*}{$\begin{array}{l}0 \\
Z \\
Z\end{array}$} & \multicolumn{9}{|c|}{ Matrículas de Educação Básica por Modalidade e Etapa de Ensino } \\
\hline & \multirow{3}{*}{ 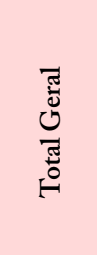 } & \multicolumn{6}{|c|}{ Ensino Regular } & \multirow{3}{*}{ 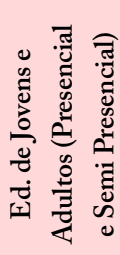 } & \multirow{3}{*}{ 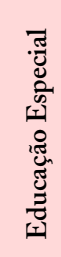 } \\
\hline & & \multirow[b]{2}{*}{ 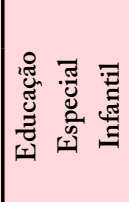 } & \multicolumn{3}{|c|}{ Ensino Fundamental } & \multirow[b]{2}{*}{ 寻 } & \multirow{2}{*}{ 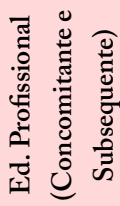 } & & \\
\hline & & & 퓽 & 苂 & 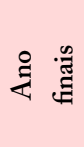 & & & & \\
\hline 2007 & 208.205 & 18.389 & 151.323 & 112.673 & 38.650 & 14.987 & 0 & 23.403 & 103 \\
\hline 2008 & 205.871 & 20.281 & 151.788 & 112.358 & 39.430 & 11.466 & 1.367 & 20.766 & 203 \\
\hline 2009 & 229.945 & 22.537 & 164.727 & 117.119 & 47.608 & 19.021 & 152 & 23.343 & 165 \\
\hline 2010 & 246.793 & 22.048 & 175.032 & 119.597 & 55.435 & 27.615 & 1.021 & 20.997 & 80 \\
\hline 2011 & 243.599 & 23.782 & 175.098 & 121.167 & 53.931 & 19.193 & 1.639 & 23.794 & 93 \\
\hline 2012 & 234.869 & 22.856 & 167.338 & 113.495 & 53.843 & 17.586 & 824 & 26.022 & 243 \\
\hline 2013 & 238.113 & 22.612 & 175.348 & 115.420 & 59.928 & 15.721 & 567 & 23.834 & 31 \\
\hline $\begin{array}{c}\% \\
2012 / \\
2013\end{array}$ & 1,4 & $-1,1$ & 4,8 & 1,7 & 11,3 & $-10,6$ & $-31,2$ & $-8,4$ & $-87,2$ \\
\hline
\end{tabular}

Fonte: MEC/Inep/Deed

Os dados disponibilizados pelo INEP (2014), referentes ao censo escolar, é um "resumo técnico" da situação das matrículas na educação básica brasileira. As informações da Tabela 1 representam a situação da educação básica em áreas indígenas, porém, há de se considerar que muitas aldeias ainda não possuem algumas modalidades de ensino, como a Educação Infantil, para a qual muitos povos não veem necessidade, pois as mães trabalham na própria aldeia; o Ensino Médio, que não é a realidade de 
todas as aldeias, pois, em muitas localidades, para dar prosseguimento aos estudos os jovens deixam sua Terra e vão para a área urbana; e a educação profissionalizante, que, embora o censo não tenha especificado a natureza dessa modalidade de ensino, apresentou uma queda expressiva de 31,2\% entre 2012 a 2013.

A diversidade dos povos indígenas se reflete também na diversidade das escolas presentes em seus territórios, de modo especial, após a Constituição vigente que assegurar o direito à diversidade, à diferença. Historicamente, são diversas as iniciativas de educação escolar desenvolvidas em contextos indígenas. No texto que segue, faço uma breve contextualização a respeito de algumas tipologias de escolas indígenas:

\section{a) Escolas para índios nas missões}

Para Luciano (2013), durante o período em que a educação escolar foi uma imposição aos povos indígenas, promovendo ações marcadas pela negação cultural e pelas tentativas de integração indígena à sociedade nacional, não cabe a denominação de "escola indígena”, uma vez que esta pressupõe algum nível de participação e protagonismo indígena.

Historicamente, a educação escolar no Brasil tem início com as missões implantadas por padres jesuítas, a fim de atrair e de catequizar os povos indígenas. Atuando junto aos colonizadores, os religiosos implantaram diversas missões em todo o território, atuando na "educação" e evangelização dos povos indígenas, com objetivo de "demarcar" e povoar o território “conquistado" pela coroa portuguesa.

Para Ferreira (2001), a educação escolar indígena, no período colonial, tinha como principal objetivo "negar a diversidade dos índios", aniquilando suas culturas para melhor integrar a "mão de obra indígena à sociedade nacional”. Outra característica marcante dessa época, apresentada pela autora, foi a imposição da língua portuguesa a fim de promover a assimilação dos índios à civilização cristã por meio dos religiosos da igreja católica, com seus internatos e escolas que obrigavam os ameríndios a renunciar à sua cultura, favorecendo assim o controle colonial. 


\section{b) Escolas dos postos indígenas}

Trata-se das escolas dos postos, instituições escolares construídas por indigenistas que atuavam junto aos postos indígenas do Serviço de Proteção ao Índio - SPI, a partir de 1910, e, mais tarde (1967), da Fundação Nacional do Índio - FUNAI.

A FUNAI, ao contatar um grupo indígena, seguia uma política de "atração" desse povo. A princípio, deixava presentes para conquistar a confiança do grupo e, logo depois, os atraia para grandes aldeias, chamadas de posto indígena, com a instalação de escolas, posto de saúde e a casa do indigenista chefe do posto, responsável por comandar as atividades locais, inclusive impondo o modo de trabalho dos não índios aos indígenas.

Nas escolas dos postos, embora as instalações se assemelhassem às das missões, as condições de funcionamento eram bastante diferentes. Os primeiros professores foram funcionários do próprio órgão tutor, ou seus cônjuges. Mais tarde, a FUNAI contratava professores na cidade para atuar junto às escolas dos postos, à distância, e a dificuldade em ensinar a língua portuguesa aos falantes da língua materna comprometeu a regularidade das atividades escolares e acarretou frequentes interrupções no processo de ensino-aprendizagem. Para reduzir a dependência externa, alguns professores indígenas assumiram as escolas e passaram a cobrar do poder público a oferta de curso de formação específico (SECCHI, 2012).

\section{c) Escola da aldeia}

As escolas da aldeia, em sua maioria, são compostas pelas escolas de pequeno porte, multisseriadas e unidocentes, localizadas em aldeias com pequeno contingente populacional. No geral suas instalações são simples, restringindo-se a uma ou duas salas de aula (SECCHI, 2012). Há também escolas que oferecem todo o Ensino Fundamental e Médio, de médio ou grande porte, pertencentes às redes municipais e estaduais, porém instaladas apenas em algumas aldeias específicas.

Embora uma das características na escola da aldeia seja a atuação do professor indígena, isso não garantiu o rompimento com a educação 
assimilacionista e homogeneizante. Mesmo após a Constituição Federal vigente, que garante as escolas indígenas diferenciadas, continuava-se a reproduzir a cultura dominante na instituição escolar da aldeia, por meio de conteúdos e castigos físicos ${ }^{11}$.

No geral, as escolas da aldeia são atendidas por professores indígenas dos respectivos povos, formados ou em formação em diversos cursos, como o projeto Tucum, o Projeto Pedra Brilhante-Urucum (MT), o Projeto Açaí (RO), as Licenciaturas Indígenas, entre outros em todo o país. Seus Professores são contratados a título precário, enquanto concluem o Ensino Médio ou o Superior indígena (SECCHI, 2012). Poucos são os que foram efetivados por concurso público. Atualmente, a educação intercultural é um conceito permanente no horizonte escolar das escolas da aldeia.

\section{d) Escola indígena itinerante}

A experiência escolar, de caráter itinerante, preponderou junto ao povo indígena Nambikwara. São escolas cuja localização real coincide com os diferentes locais, dentro do espaço do território tradicional, em que o professor acompanha os grupos em suas atividades habituais.

A escola itinerante foi a maneira adequada que os grupos Halotesu, Wakalitesu, Kithaulhu e Sawantesu, do povo Nambikwara, encontraram para enquadrar a educação escolar em seu estilo de vida, seguindo seu calendário sazonal. Destaca-se, ainda, o uso de narrativas indígenas relacionadas aos diversos fatos históricos vivenciados pelos grupos, que serviam de ponto de partida às aulas de História, Língua Portuguesa e Matemática dos primeiros anos do Ensino Fundamental (COSTA, 2014).

$\mathrm{Na}$ educação itinerante dos Nambikwara, ainda que a escola tenha um endereço oficial e seja do conhecimento de todos, "[..] as atividades educativas se restringem aos tempos e aos espaços disponível em situações

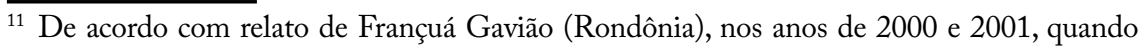
frequentou a escola da aldeia, os professores indígenas prendiam os alunos que se levantavam repetidas vezes durante a aula, à cadeira, com fita adesiva. Para Francuá, os professores indígenas estavam colocando em práticas as orientações recebidas nos cursos de formação, que era de fazer com que os alunos ficassem em sala a qualquer custo. (Relato do Françuá Gavião, durante o curso do Ministério Indígena Intercultural da Aldeia-escola Zarup Wej, julho de 2016).
} 
de seminomadismo. Ao invés de os alunos se dirigirem à escola, é esta que os acompanha e se concretiza na figura do professor itinerante" (SECCHI, 2012, p. 334).

\section{e) Escolas sem escolas}

A escola, sem um espaço estruturado formalmente como escola, faz parte do processo de aquisição da leitura e da escrita entre os Enawene-Nawe, povo cujo território se localiza na região Médio Norte de Mato Grosso.

Essa realidade peculiar de escola representa um modelo bastante específico de ensino-aprendizagem da educação formal. Os Enawene-Nawe são um dos poucos povos no Brasil que (ainda) não associaram a leitura e a escrita à escola. Ou seja, “[...] apreendeu o código escrito por sua magia, exoticidade, utilidade, ou qualquer outro motivo, mas sempre dissociado da instituição escolar conhecida no mundo ocidental". Outro fato específico desse povo é que os "[...] Enawene-nawe é uma das poucas sociedades no mundo que conhece e utilizou a produção de filmes e vídeos antes da técnica de leitura e escrita" (SECCHI, 2012, p. 334).

\section{f) Escola da floresta}

O termo "escola da floresta" foi designado pela pesquisadora Nietta Monte para intitular as escolas dos Kaxunawá. Monte acompanhou o processo de construção do "pensar coletivo" de uma proposta curricular que levae em conta a cultura do povo em diálogo com a cultura nacional. Nesse processo, os professores buscam "[...] pensar seu cotidiano curricular, para maior compreensão da descontinuidade e fragmentação do real vivido em sala de aula" (MONTE, 1996).

A instituição escolar dos Kaxinawá do Jordão, cujo território localiza-se no Sudoeste do Estado do Acre, fronteira com o Peru, são escolas localizadas em meio à floresta Amazônica, em pleno conflito com o modelo e estrutura de educação da cultura dominante imposta aos povos indígenas.

Embora a luta contra a educação homogeneizante e a busca por uma proposta curricular que contemple a pedagogia tradicional dos povos 
indígenas não seja uma preocupação exclusiva da escola da floresta dos Kaxunawá, evidencia-se a importância de incorporar a interculturalidade no contexto escolar indígena e de repensar as próprias práticas em sala de aula, em escolas indígenas e não indígenas.

\section{g) Aldeia Escola}

A aldeia-escola é uma realidade vivenciada pelo povo indígena Zoró, cujo território localiza-se a Noroeste do Estado de Mato Grosso. Essa escola, diferentemente das instituições escolares de outros povos, é um espaço (aldeia) não ocupado permanentemente, construído exclusivamente para abrigar a instituição escolar.

A ideia de construir a aldeia-escola surgiu com a necessidade de definir um local para a construção da escola Zarup Wej, a fim de contemplar algumas práticas tradicionais, como a caça, a pesca e a coleta de frutas e plantas silvestres no currículo da escola. Escolheu-se um local ambientalmente bem preservado, propício a essas práticas, visto que, com o processo de colonização no Noroeste de Mato Grosso, a Terra Zoró foi completamente invadida e boa parte do recurso florestal destruído. Muitas aldeias ainda não conseguiram se recuperar da destruição, o que dificulta que os sabedores da cultura repassem aos jovens técnicas tradicionais do povo; assim, a aldeia-escola se torna um espaço destinado à aprendizagem da cultura tradicional Zoró e dos conhecimentos da sociedade nacional.

A escola, pertencente à área administrativa do Estado do Mato Grosso, atende exclusivamente os estudantes Zoró, nas modalidades do Ensino Fundamental e Médio; além disso, funciona em regime de alternância, com objetivo de facilitar a frequência dos alunos na escola, uma vez que algumas aldeias ficam muito longe da instituição. O calendário escolar é organizado em sessões escolares (7 no total), alternadas com sessões de aplicação que se caracterizam como atividades cotidianas que são registradas pelos estudantes em suas respectivas aldeias (PPPZ, 2009).

Como podemos perceber, no que se refere a escolas indígenas, é inadequado abordá-las no singular, diante tamanha diversidade (SECCHI, 2012). 
Desconsiderar a diversidade das escolas é tratar os povos indígenas de maneira genérica, desconsiderando suas culturas, saberes e valores diversos, que contribuem para a ressignificação da instituição escolar em suas comunidades.

No que se se refere às escolas indígenas, Scaramuzza $(2015$, p. 1) defende que é possível que a interculturalidade ocorra nesses ambientes, quando ressignificados e apropriados a favor da cultura e identidade de cada povo, "mesmo com as tensões e os desafios que enfrentam para afirmarem-se diferentes".

Para falar de uma educação escolar e diferenças, faz-se necessário considerar os processos históricos instituintes específicos de cada escola, a indígena, a do campo, a quilombola etc, a fim de trazer à tona suas lutas, conquistas e desafios, pois sabemos que, por muito tempo, essas instituições privilegiaram os saberes ditos universais, desprezando e anulando a diversidade nacional.

\section{Conclusão}

Como podemos perceber, a educação sempre esteve arraigada com os processos homogeneizante, com o objetivo de impor a cultura dominante, negando as diferenças e a diversidade cultural. Vimos também que é preciso ir além do discurso de igualdade educacional, é preciso que as diferenças sejam aceitas e compreendidas dentro de uma multiplicidade, no âmbito das escolas e fora dela.

As diferenças, como aponta Candau (2011), devem ser reconhecidas e valorizadas de maneira positiva, privilegiando as dinâmicas de identidade. No entanto, é preciso, ao mesmo tempo, combater as tendências que transformam as diferenças em desigualdades, preconceito e segregação.

Desse modo, ao falar de diferenças no âmbito da educação brasileira, é preciso considerar a diversidade das escolas que atendem a população multicultural do país. Assim, torna-se necessário também que as instituições escolares atendam as especificidades dos povos indígenas, quilombolas, entre ouros, considerando suas culturas, saberes e valores diversos, que contribuem para a ressignificação da instituição escolar em suas comunidades. 


\section{Referências}

BRASIL. Assembleia Nacional Constituinte. Constituição da República Federativa do Brasil de 1988. Brasília: Assembleia Nacional Constituinte, 5 out.1988.

Censo demográfico 2010: Características gerais dos indígenas, resultados do universo. In: Instituto Brasileiro de Geografia e Estatística. Rio de Janeiro, 2010, p. 1-245. Disponível em: ftp://ftp.ibge.gov.br/Censos/Censo_Demografico_2010/Caracteristicas_ Gerais_dos_Indigenas/pdf/Publicacao_completa.pdf. Acesso em: 2 mar. 2015.

Ministério da Educação e do Desporto. Secretaria de Ensino Fundamental. Diretrizes para a Política Nacional de Educação Escolar Indígena de 1993. 2. ed. Brasília: MEC/SEF/DPEF, 1994.

Presidência da República. Casa Civil. Subchefia para Assuntos Jurídicos. Decreto no 26, de 4 de fevereiro de 1991. Dispõe sobre a Educação Indígena no Brasil. Brasília: DOU, 5 fev.1991.

Presidência da República. Casa Civil. Subchefia para Assuntos Jurídicos. Lei no 9.394, de 20 de dezembro de 1996. Estabelece as diretrizes e bases da educação nacional. Brasília: DOU, 23 dez.1996. Disponível em: <http:/www.planalto.gov.br/ccivil_03/leis/ L9394.htm>. Acesso em: 20 jul. 2016.

Presidência da República. Casa Civil. Subchefia para Assuntos Jurídicos. Lei no 11.645, de 10 de marco de 2008. Altera a Lei no 9.394, de 20 de dezembro de 1996, modificada pela Lei no 10.639, de 9 de janeiro de 2003, que estabelece as diretrizes e bases da educação nacional, para incluir no currículo oficial da rede de ensino a obrigatoriedade da temática "História e Cultura Agro-Brasileira e Indígena". Brasília: DOU, 11 mar.2008. Disponível em: <http://www.planalto.gov.br/ccivil_03/_ato2007-2010/2008/lei/111645.htm>. Acesso em: 20 jul. 2016.

Presidência da República. Casa Civil. Subchefia para Assuntos Jurídicos. Lei no 13.005, de 25 de junho de 2014. Aprova o Plano Nacional de Educação - PNE e dá outras providências. Brasília: DOU, 26 jun.2014. Disponível em:<http://www2.camara.leg. br/legin/fed/lei/2014/lei-13005-25-junho-2014-778970-publicacaooriginal-144468-pl. html>.Acesso em: abr. 2016.

./SEESP. Política Nacional de Educação Especial na Perspectiva da Educação Inclusiva. Documento elaborado pelo Grupo de Trabalho nomeado pela Portaria Ministerial no 555, de 5 de junho de 2007, prorrogada pela Portaria no 948, de 09 de outubro de 2007. Disponível em: <http://peei.mec.gov.br/arquivos/politica_nacional_educacao_especial.pdf $>$ Acesso em jul. 2016.

Ministério da Educação e Desporto. Secretaria de Educação Fundamental. Referencial Curricular Nacional para as Escolas Indígenas. Brasília: MEC/SEF, 1998. 
CANDAU, Vera Maria Ferrão. Diferenças culturais, cotidiano escolar e práticas pedagógicas. Currículo sem Fronteiras, [online], v. 11, n. 2, p. 240-255, jul./dez. 2011. Disponível em: <http://www.curriculosemfronteiras.org/vol11iss2articles/candau.htm>Acesso em: 20 jul. 2016.

CANDAU, Vera Maria Ferrão. Diferenças culturais, interculturalidade e educação em direitos humanos. Educ. Soc., Campinas, v. 33, n. 118, p. 235-250, jan./mar. 2012. Disponível em <http://www.cedes.unicamp.br> Acesso em: 26 mar. 2015.

COSTA, Anna Maria Ribeiro F. M. O "povo das cinzas” e os "comedores de feijão": um encontro intermediado pela educação escolar indígena. In: ENCONTRO ESTADUAL DA ANPUH - SP, 21. Anais Eletrônicos ... Santos, SP, 2014. Disponível em:<www. encontro2014.sp.anpuh.org/.../1406756147_ARQUIVO_Opovodascinzaseosco..> Acesso em: 15 abr. 2016.

FERRARI, Anderson. Diferença, igualdade e formação de identidade no contexto escolar. Instrumento: revista de estudo e pesquisa em educação/Universidade Federal de Juiz de Fora - v. 1, maio 2000.

FERREIRA, Mariana Kawal Leal. A educação escolar indígena: um diagnóstico crítico da situação no Brasil. In: LOPES DA SILVA, Aracy; FERREIRA, Mariana Kawal Leal. (Orgs.). Antropologia, história e educação: a questão indígena na escola. São Paulo: Global, 2001.

FREIRE, Paulo. Pedagogia do oprimido. Rio de Janeiro: Paz e Terra, 2005.

GUSMÃO, Neusa Maria Mendes de. Antropologia, Estudos Culturais e Educação: desafios da modernidade. Pro-Posições, v. 19, n. 3, p. 57, set./dez. 2008. Disponível em: <www. scielo.br/pdf/pp/v19n3/v19n3a04>. Acesso em: 14 jul. 2016.

JESUS, Jose Novais. Pedagogia da alternância e o debate da educação no/do campo no estado de Goiás. In: Revista NERA, Presidente Prudente, Ano 14, n. 18, p. 7-20, jan./jun.2011. Disponível em:<http://www.reformaagrariaemdados.org.br/sites/default/files/1334-37981-PB.pdf> Acesso em: 15 jun. 2016.

INEP. Instituto Nacional de Estudos e Pesquisas Educacionais Anísio Teixeira. Censo Escolar da Educação Básica 2013: resumo técnico. Brasília: INEP, 2014.

LUCIANO, Gersen dos Santos. Educação escolar indígena no Brasil: Avanços, limites e novas perspectivas. In: REUNIÃO NACIONAL DA ANPED, 36, 2013, Goiânia, GO. Anais..., Goiânia: ANPED, 2013. Acesso em: 15 abr. 2015.

MATO GROSSO. Secretaria Estadual de Educação. Governo do Estado do Mato Grosso. Projeto Político Pedagógico da Educação Básica Intercultural Específica para o Povo Indígena Zoró. Rondolândia: SEDUC/MT, 2009. 
MAROUN, Kalyla. Jongo e educação escolar quilombola: diálogos no campo do currículo. In: Cadernos de Pesquisa, v. 46, n.160, p. 484 - 502, abr./jan. 2016. Disponível em: <http://publicacoes.fcc.org.br/ojs/index.php/cp/article/view/3357/pdf_9 >. Acesso em: 20 jun. 2016.

MARQUES, Luciana Pacheco. Cotidiano escolar e diferenças. In: Educ. foco, Juiz de Fora, v. 17, n. 1, p. 101-117, mar. / jun. 2012. Disponível em: http://www.uff.br/revistaedufoco/ files/2012/10/Cotidiano-escolar-ediferen\%C3\%A7as.pdf Acesso em: 5 jul. 2016.

MCLAREN, Peter. Multiculturalismo Crítico. São Paulo: Cortez, 1994.

MIRANDA, Arlete Aparecida Bertoldo. História, deficiência e educação especial. 2003. Disponível em: <http://www.histedbr.fe.unicamp.br/revista/revis/revis15/art1_15.pdf> Acesso em: 17 jul. 2016.

MONTE, Nietta Lindenberg. Escolas da Floresta: Entre o passado oral e o presente letrado, diários de classe de professores Kaxinawá. Rio de Janeiro: Multiletra, 1996.

SACRISTÁN, José Gimeno. Políticas de la diversidad para uma educación democrática igualizadora; In: SIPÁN COMPAÑE, A. (Coord.). Educar para ladiversidadenelsiglo XXI. Zaragoza: Mira Editores, 2001.

SAVIANI, Dermeval. O legado educacional do "longo século XX" brasileiro. In: SAVIANI, Dermeval; ALMEIDA, J. S.; SOUZA, R. F. de; VALDEMARIN, V. T. O legado educacionaldo século XX no Brasil. Campinas: Autores Associados, 2006.

SCARAMUZZA, Genivaldo Frois; NASCIMENTO, Adir Casaro; KAPIAAR GAVIÃO, Zacarias Kapiaar. Os Ikolen (Gavião) de Rondônia: escola e ensaios de interculturalidade. In: Tellus, ano 15, n. 29, p. 3-18, jul./dez. Campo Grande/MS, 2015. Disponível em:http:// www.gpec.ucdb.br/projetos/tellus/index.php/tellus/article/view/376. Acesso em: jul. 2016.

SECCHI, Darci. A formação de professores indígenas para a diversidade. In: Revista de Educação Pública. v. 21, n. 46, Cuiabá, maio/ago. 2012.

SOUZA, Maria Antônia de. Educação do Campo: propostas e práticas pedagógicas do MST. Petrópolis, RJ: Vozes, 2006.135p.

RAFANTE, Heulalia Charalo. Política de educação especial no Brasil: a relação entre o estado, a sociedade civil e as agências internacionais na criação do CENESP. In: 37a Reunião Nacional da ANPEd - 4 a 8 de outubro de 2015, UFSC - Florianópolis. Disponível em: <www.anped.org.br/sites/default/files/trabalho-gt15-3916.pdf>. Acesso em: abr. 2016.

REVISTA NOVA ESCOLA. Os desafios da Educação inclusiva: foco nas redes de apoio. Disponível em: http://novaescola.org.br/formacao/palavra-especialista-desafios-educacao-inclusiva-foco-redes-apoio-734436.shtml Acesso em: 15 jul. 2016. 


\section{SOBRE OS ORGANIZADORESE ORGANIZADORAS, AUTORESE AUTORAS}

\section{Adir Casaro Nascimento (PPGE/UCDB/MS):}

Possui graduação em Pedagogia pela Universidade Católica Dom Bosco (1971), mestrado em Educação pela Universidade Federal de Mato Grosso do Sul (1991) e doutorado em Educação pela Universidade Estadual Paulista Júlio de Mesquita Filho (2000). Professora e pesquisadora do Programa de Pós-Graduação em Educação - Mestrado e Doutorado da UCDB. Líder do Grupo de Pesquisa Educação e Interculturalidade/CNPq. Coordena o Observatório da Educação/Edital 049/2012 - Núcleo UCDB, com o projeto: Formação de professores indígenas Kaiowá e guarani em Mato Grosso do Sul: relações entre territorialidade, processos próprios de aprendizagem e educação escolar. Tem experiência na área de Educação, com ênfase em Educação Indígena. E-mail: adir@ucdb.br

\section{Anatália Daiane de Oliveira (PPGE/UFMT): Anatália Daiane de Oliveira Ramos (UNIR/UFMT):}

Doutora em Educação pela Universidade Federal de Mato Grosso (UFMT). Pedagoga e mestra em Psicologia pela Fundação Universidade Federal de Rondônia (UNIR). Pesquisadora do Grupo de Pesquisa de Educação na Amazônia (GPEA) da UNIR. Participante do Grupo de Estudos e Pesquisas sobre Trabalho e Educação (GEPTE) da UFMT. E-mail: anataliadaiane@hotmail.com.

\section{Anderson Martins (PPGE/UFMT):}

Bacharel e licenciado em Filosofia pela Faculdade Jesuíta - FAJE/ MG (2006); possui especialização em Metodologia do Ensino de Filosofia e Sociologia, através da Faculdade da Lapa - FAEL/PR (2010). 
Atualmente é discente do curso de Mestrado em Educação no Programa de Pós-Graduação em Educação pela Universidade Federal de Mato Grosso UFMT/PPGE. Há vários anos, trabalha como professor da rede pública de ensino na região de Juína/MT. Iniciou suas atividades docentes junto a uma comunidade do povo Rikbaktsa, cuja experiência despertou o seu interesse pela reflexão em torno da educação escolar indígena. E-mail: anderson. juina@hotmail.com

\section{Antonio Hilario Aguilera Urquiza (PPGAnt/UFGD):}

Professor da Pós-graduação em Direitos Humanos e da Pós-Graduação em Antropologia da UFMS e professor colaborador da Pós-Graduação em Educação da UCDB. Pós-doutorado em Antropologia na UNTREF (Argentina)..E-mail: hilarioaguilera@gmail.com

\section{Armelinda Borges da Silva (PPGE/UFMT):}

Mestra em Educação pela Universidade Federal de Mato Grosso (UFMT). Pedagoga pela Fundação Universidade Federal de Rondônia (UNIR/Campus de Ji-Paraná). Membro do Grupo de Pesquisa em Educação na Amazônia (GPEA), atua na Linha de Pesquisa "Antropologia Etnopedagógica: Povos Indígenas, Interculturalidade e Currículo”. E-mail: armelindabs@gmail.com.

\section{Beleni Saléte Grando (PPGE/UFMT):}

Professora da Universidade Federal de Mato Grosso no Programa de Pós-Graduação em Educação, Coordenadora do Procad-Amazônia/ CAPES - rede UFMT, UFPA, UFAM. Coordenadora do Grupo de Pesquisa Corpo, Educação e Cultura - COEDUC/UFMT e Pesquisadora colaboradora do MOVER/UFSC - E-mail: beleni.grando@gmail.com

\section{Darci Secchi (PPGE/UFMT):}

Professor Associado IV da Universidade Federal de Mato Grosso, membro do Programa de Pós-Graduação em Educação - PPGE e coordenador do Grupo de Pesquisa em Educação Intercultural Indígena. É 
doutor em Ciências Sociais (Antropologia) pela Pontifícia Universidade Católica de São Paulo, editor da Revista Eletrônica Pedagogia UFMT e tutor do Grupo PET-Educação. E-mail: darci.secchi@gmail.com

\section{Emanuelly Cristiny Vieira Rodrigues (MAPSI/UNIR):}

Bacharel e Licenciada em Psicologia pela Universidade Federal de Rondônia - UNIR (2010). Especialista em Psicologia do Trânsito pela Universidade Paulista - UNIP/UFAL (2014). Mestre em Psicologia pelo Mestrado Acadêmico em Psicologia - MAPSI/ UNIR (2015). Psicóloga credenciada do Departamento de Trânsito de Rondônia - DETRAN/RO, desde 2011. E-mail: manu.cristiny@gmail.com

\section{Heitor Queiroz de Medeiros (PPGE/UCDB):}

Doutorado em Ciências - Ecologia e Recursos Naturais, pela Universidade Federal de São Carlos (UFSCar), 2006. Mestrado em Ciência Ambiental, pela Universidade de São Paulo (USP), 1999. Graduação em História pela Universidade Federal de Mato Grosso (UFMT), 19791982 e Faculdades Unidas Católica de Mato Grosso (FUCMAT), 1983. Atualmente é Professor na Universidade Católica Dom Bosco (UCDB) no Programa de Pós-Graduação em Educação (Mestrado e Doutorado), atuando na Linha de Pesquisa Diversidade Cultural e Educação Indígena. Tem experiência nas áreas de Docência de Ensino Superior, Educação Escolar Indígena, Educação Ambiental, Educação do Campo, Ciências Ambientais, História e Meio Ambiente, Políticas Públicas. E-mail: 4668@ ucdb.br

\section{José Lucas Pedreira Bueno (PPGE/UFTM; PPGEEProf/UNIR):}

Professor do Departamento de Ciências da Educação da Universidade Federal do Triângulo Mineiro e do Programa de Pós-graduação em Educação - Mestrado Acadêmico e do Programa de Pós-graduação em Educação Escolar, Mestrado e Doutorado Profissional (PPGEEProf). Pesquisador da área de Formação de professores; Tecnologia educacional; Tecnologias aplicadas à educação; Educação a distância; Letramento e 
inclusão digital e Cultura, mídia e educação. Licenciado em Letras (Português e Inglês) e Especialista em Língua Portuguesa pela UEMG. Graduado em Gestão da Tecnologia da Informação pela Unisul. Mestre e Doutor em Engenharia de Produção pela UFSC.E-mail: 7lucas@gmail.com

\section{Josélia Gomes Neves (PPGEEProf/UNIR):}

Professora doutora da Universidade Federal de Rondônia. Docente do Programa de Pós-Graduação em Educação Escolar, Mestrado e Doutorado Profissional (PPGEEProf). Líder do Grupo de Pesquisa em Educação na Amazônia (GPEA), coordenadora da Linha de Pesquisa Antropologia Etnopedagógica: Povos Indígenas, Intercultualidade e Currículo. Coordena o Projeto de Iniciação Científica: Karo \& Ikolen: História e Culturas Indígenas na perspectiva da Lei 11.645/2008 e o Programa de Extensão Universitária: "Pamakóbáe Poutígie" (Ikolen) "Imayahmây nã kamã” (Karo) na Terra indígena Igarapé Lourdes, Ji-Paraná-RO. Orienta o Subprojeto do PPP e Alfabetização Intercultural no PIBID Diversidade junto a bolsistas indígenas dos Povos Gavião, Arara, Suruí, Negarotê, Puruborá, Kaxarari e Migueleno. E-mail: joselia.neves@pq.cnpq.br

\section{Juracy Machado Pacífico (PPGEEProf/UNIR):}

Professora do Departamento de Ciências da Educação e do Programa de Pós-graduação em Educação Escolar, Mestrado e Doutorado Profissional (PPGEEProf), da Fundação Universidade Federal de Rondônia (UNIR). Doutora em Educação Escolar (UNESP/2010), Mestre em Psicologia Escolar (USP/2000) e graduada em Pedagogia (UNIR/1996). É coordenadora do Programa de Pós-graduação em Educação Escolar Mestrado Profissional. Coordenou o Curso de Pós-Graduação (lato sensu) em Docência na Educação Infantil (UNIR/UNDIME/SEB/MEC). É líder do Grupo de Pesquisa Multidisciplinar em Educação e Infância Grupo Educa. E-mail: juracypacifico@unir.br. 


\section{Maria Angela de Arruda Bastos (SEDUC/MT):}

Graduada em Letras - Português/Inglês pela Universidade de Cuiabá - UNIC (1999). Professora aposentada pela Secretaria de Estado de Educação de Mato Grosso (SEDUC-MT). E-mail: m.angela28@hotmail.com

\section{Maria Isabel Alonso Alves (UFAM; PPGE/UCDB):}

Professora do magistério superior na Universidade Federal do Amazonas - UFAM. Atua também como pesquisadora no âmbito do Grupo de Pesquisa em Educação na Amazônia (GPEA/UNIR), na Linha de Pesquisa Povos indígenas na escola pública: repercussões da Lei 11.645/2008. É mestra em Educação, formada pelo Programa de Pós-Graduação em Educação (PPGE) da Universidade Federal de Rondônia, vinculada à Linha de Pesquisa: Formação de professores, onde investigou a produção de identidades indígenas e o significado da educação superior indígena a partir do Curso de Licenciatura em Educação Básica Intercultural da UNIR - Campus de Ji-Paraná. Atualmente desenvolve estudos na linha de pesquisa Diversidade Cultural e Educação Indígena no Programa de Doutorado em Educação da Universidade Católica Dom Bosco - UCDB/MS. E-mail: mialonsoster@gmail.com

\section{Maria Ivonete Barbosa Tamboril (MAPSI/UNIR):}

Possui graduação em Pedagogia pela Universidade Federal de Rondônia (1996), mestrado e doutorado Psicologia Escolar e do Desenvolvimento Humano pela Universidade de São Paulo (2000; 2005). É professora Associada - Nível 2 da Universidade Federal de Rondônia, atuando no Curso de Graduação em Psicologia e no Programa de Pós-Graduação em Psicologia (MAPSI) da Universidade Federal de Rondônia (UNIR). Tem experiência na área de Psicologia, com ênfase em Psicologia Escolar e do Desenvolvimento Humano. Atua principalmente nos seguintes temas: formação docente, Grupo focal, Política educacional, Projeto político pedagógico, Reformas educacionais e Desenvolvimento profissional. E-mail: ivonetetamboril@unir.br 


\section{Marli Lúcia Tonatto Zibetti (PPGPsi/PPGEEProf/UNIR):}

Doutora em Psicologia Escolar e do Desenvolvimento Humano pela Universidade de São Paulo (USP). Professora do Departamento de Psicologia atuando nos Programas de Pós-Graduação em Psicologia e Pós-Graduação em Educação Escolar da Fundação Universidade Federal de Rondônia (UNIR). Líder do Grupo Amazônico de Estudos e Pesquisas em Psicologia e Educação (GAEPPE), vice-líder do grupo Psicologia Escolar e Educacional: processos de escolarização e atividade profissional em uma perspectiva crítica do Instituto de Psicologia da USP. E-mail: marlizibetti@unir.br

\section{Patrícia Dias (SEDUC/MT):}

Professora da educação básica na Secretária de Educação do Estado do Mato Grosso. Mestre em Educação pela Universidade Federal de Mato Grosso (UFMT). Graduada em Pedagogia pela Fundação Universidade Federal de Rondônia (UNIR/Campus de Ji-Paraná), ano de 2013. Membro do Grupo de Pesquisa em Educação na Amazônia (GPEA). patriciadias1409@gmail.com

\section{Neide da Silva Campos (COEDUC/PPGE/UFMT):}

Professora da Secretaria de Estado de Educação de Mato Grosso (SEDUC-MT), doutoranda do Programa de Pós-Graduação em Educação da Universidade Federal de Mato Grosso - PPGE/UFMT; pesquisadora do Grupo de Pesquisa Corpo, Educação e Cultura - COEDUC/PPGE/ UFMT. E-mail: neidinhaufmt@gmail.com

\section{Regina Aparecida Costa (PPGE/UNIR):}

Mestra em Educação, pela Fundação Universidade Federal de Rondônia (2012/UNIR), na linha de pesquisa: Política Pública Educacional. Mestrado em Liderança pela Universidade Santo Amaro (2008). Pós-Graduação em Metodologia e Didática do Ensino Superior (2007). Pós-Graduada em Marketing pela Fundação Getúlio Vargas - FGV (1996). 
Possui graduação em Comunicação Social - Faculdades Integradas Alcântara Machado (1992). Atualmente é professor/tempo parcial - Faculdades Integradas de Ariquemes, nas disciplinas Administração Mercadológica I e II; Gestão de Projetos no curso de Administração; Metodologia da Pesquisa e Trabalho de Conclusão de Curso - TCC, no curso de Ciências Contábeis e no curso de História. Coordenadora da Comissão Própria de Avaliação (CPA) e coordenadora da empresa-júnior - FIAR. E-mail: reginacosta_ro@yahoo.com.br

\section{Rozane Alonso Alves (PPGE/UCDB):}

Formada em Pedagogia pela Fundação Universidade Federal de Rondônia - UNIR, Campus de Ji-Paraná. Especialista em Supervisão, Orientação e Gestão com ênfase em Psicologia Educacional. Mestra em Educação pela Faculdade de Educação - FACED, da Universidade Federal do Rio Grande do Sul. Doutora em Educação pela Universidade Católica Dom Bosco - UCDB. É pesquisadora do Grupo de Pesquisa em Educação na Amazônia - GPEA. Atua com Infâncias Amazônicas, Educação e Interculturalidade e Educação Infantil. Professora efetiva da Universidade Federal do Amazonas - UFAM. E-mail: rozanealonso@gmail.com

\section{Shelly Braum (PPGEE/UNIR):}

Possui graduação em Letras - Português e Espanhol pela Universidade do Tocantins (2010). Mestre em Educação Escolar pelo Programa de Pós-Graduação em Educação Escolar, Mestrado e Doutorado Profissional (PPGEEProf). Atualmente é professora EBTT de Língua Espanhola do Instituto Federal de Educação, Ciência e Tecnologia de Rondônia. Tem experiência na área da Educação, com ênfase em Língua Portuguesa e Espanhola, atuando principalmente nos seguintes temas: Desafio à docência, Língua Espanhola, Abordagem Comunicativa.E-mail: shelly.braum@ifro.edu.br

\section{Suzana Helena Alves Arruda: (SEDUC/MT):}

Mestra em Ensino pelo Instituto Federal de Educação, Ciência e Tecnologia de Mato Grosso - IFMT, parceria com a Universidade de Cuiabá - UNIC 
(2018). Graduada em Ciências/Matemática pela Universidade de Cuiabá (1999). Professora de Matemática da Secretaria de Estado de Educação de Mato Grosso (SEDUC-MT).E-mail: suzanaarruda123@gmail.com

\section{Sônia Rocha Lucas (Saberes/UFGD):}

Mestra em Antropologia no Programa de Pós Graduação em Antropologia (PPGAnt/UFGD). Graduada em Ciências Sociais da UFMS, participa do Grupo de Pesquisa Antropologia, Direitos Humanos e Povos Tradicionais; foi bolsista do PIBIC 2012/2013/ Políticas Públicas em Comunidades Quilombolas de Mato Grosso Sul: diagnóstico de execução e levantamento das demandas e, em 2013/2014, com o tema: Crianças Kaiowá e Guarani em situação de acampamento na região sul do estado de Mato Grosso do Sul: Quem são e como percebem a situação de acampamento, o qual recebeu o prêmio Claude Lévi-Strauss / edição 2014 da 29 Reunião Brasileira de Antropologia, promovida pela Associação Brasileira de Antropologia na modalidade pôster. Usuária de LIBRAS, atualmente é supervisora da ação Saberes Indígena na Escola (MEC/SECADI), Área de Antropologia e Direitos Humanos.E-mail: soninhalucas@gmail.com

\section{Thaís Oliva Fernandes Sanders (PPGE/UFMT):}

Mestre em Educação pela Universidade Federal de Mato Grosso (UFMT). Graduada em Licenciatura em Pedagogia pelo Centro Universitário Luterano de Ji-Paraná (2006); possui especialização em Psicopedagogia Clínica (2008), Gestão Escolar (2009) e Docência do Ensino Superior e Inovações Curriculares (2014). Membro do Grupo de Pesquisa em Educação na Amazônia (GPEA). Professora da rede municipal de ensino de Ji-Paraná RO. E-mail: thaisolivasanders@gmail.com. 
A presente coletânea é o resultado da mobilização epistemológica, política e social de um coletivo de pesquisadores e pesquisadoras de três diferentes universidades brasileiras (UNIR, UFMT e UCDB). Tem como eixo comum a prática de pautar estudos acadêmicos para a justiça social, inspirados nas lutas indígenas.

O trabalho foi pensado como uma referência inaugural para marcar a presença das Ações Afirmativas na UNIR por meio do Edital 3/2016/PPGEE-MEPE através da rediscussão do acesso e ingresso oficial na PósGraduação de estudantes indígenas, negros e com deficiência - um processo que não aconteceu sem lutas. Constitui um registro do enfrentamento aos múltiplos e sutis processos de exclusão traduzidos nas permanentes reedições coloniais. As desigualdades sociais não dormem.

Representa um esforço de continuidade às publicações na perspectiva da educação crítica de visibilizar trabalhos que discutam a temática indígena produzidos em 1984 e depois em 1995 pela saudosa antropóloga educadora Aracy Lopes da Silva. 